\title{
IDENTIFICATION OF THE SPAWNING, REARING AND MIGRATORY REQUIREMENTS OF FALL CHINOOK SALMON IN \\ THE COLUMBIA RIVER BASIN ANNUAL REPORT 1992
}

Annual Report 1992

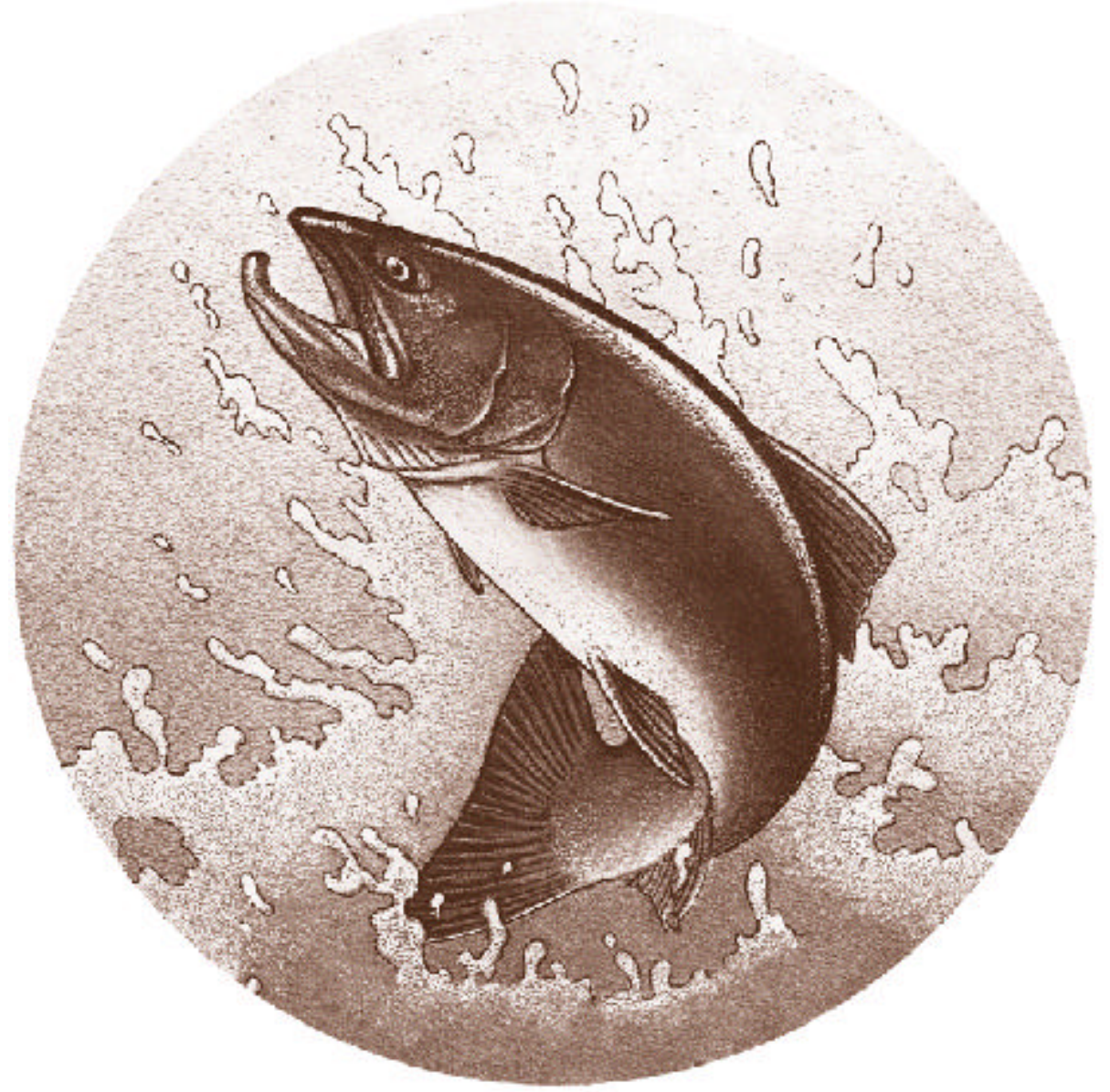


DOE/BP-21708-2

This report was funded by the Bonneville Power Administration (BPA), U.S. Department of Energy, as part of BPA's program to protect, mitigate, and enhance fish and wildlife affected by the development and operation of hydroelectric facilities on the Columbia River and its tributaries. The views of this report are the author's and do $r$ necessarily represent the views of BPA.

This document should be cited as follows:

Rondorf,Dennis W. National Biological Survey Columbia River Research Laboratory, William H. Miller U.S. Fish and Wildlife Service Idaho Fishery Resource Office, U.S. Department of Energy, Bonneville Power Administration, Division of Fish and Wildlife, Project Number1992-029, Contract NumberDE-AI79-9 1 BP2 1708, 229 electronic pages (BPA Report DOE/BP-21708-2)

This report and other BPA Fish and Wildlife Publications are available on the Internet at: http://www.efw.bpa.gov/cgi-bin/efw/FW/publications.cgi

For other information on electronic documents or other printed media, contact or write to:

Bonneville Power Administration

Environment, Fish and Wildlife Division

P.O. Box 3621

905 N.E. 11th Avenue

Portland, OR 97208-3621 


\title{
IDENTIFICATION OF THE SPAWNING, REARING AND MIGRATORY REQUIREMENTS OF FALL CHINOOK SALMON IN THE COLUMBIA RIVER BASIN
}

\author{
ANNUAL REPORT 1992
}

\author{
Prepared by: \\ Dennis W. Rondorf \\ National Biological Survey \\ Columbia River Reearch Laboratory \\ Cook WA 98605 \\ and \\ WilliamH. Miller \\ U.S. Fish and Wildlife Service \\ Idaho Fishery Resource Office \\ Ahsahka ID 83520
}

Prepared for:

U.S. Department of Energy

Bonneville Power Administration

Division of Fish and Wiidlife

P.O. Box 3621

Portland, OR 97208-362 1

Project Number92-029

Contract Number DE-AI79-9 1 BP2 1708

MARCH 1994 
Table of Contents... . . . . . . . . . . . . . . . . ii Executive Summary . . . . . . . . . . . . . . . . . . . . . . iv Acknowledgements . . . . . . . . . . . . . . . . . vii Chapter 1:

Fall chinook salmon spawning ground surveys in the Snake River . . . . . . . . . . . . . . . . . . . . . . l

Chapter 2:

Snake River flows and temperature during the 1992 Snake

River fall chinook salmon brood year. . . . . . . . 20

Chapter 3:

Swimming performance of subyearling chinook salmon • • 39

Chapter 4:

Evaluation of PIT tagging of subyearling fall chinook salmon during 1991 and 1992 . . . . . . . . . . . . . . . . . 63

Chapter 5:

Rearing and emigration of naturally produced Snake River fall chinook salmon juveniles . . . . . . . . . . . 92

Chapter 6:

Nearshore habitat use by subyearling chinook salmon in the Columbia and Snake rivers . . . . . . . . . . 120

Chapter 7:

Distribution of juvenile chinook salmon and American shad in McNary and John Day reservoirs . . . . . . . . . 151

Chapter 8:

Osmoregulatory performance and marking of subyearling

chinook salmon at McNary Dam to estimate adult

contribution . . . . . . . . . . . . . . . . . . . 171

List of Appendices . . . . . . . . . . . . . . . . 191

Appendix1 . . . . . . . . . . . . . . . . . . . . . . ..192

Appendix2 . . . . . . . . . . . . . . . . . . . . . . ..198

Appendix3 . . . . . . . . . . . . . . . . . ..208

Appendix4 . . . . . . . . . . . . . . . . . . . . . . ..214 
Appendix5 .......................216 Appendix6 ........................ . . 217 Appendix 7 . . . . . . . . . . . . . . . . 218 Appendix8 .............................. 218 Appendix9 .......................219 


\section{EXECUTIVE SUMMARY}

This document is the 1992 annual progress report for selected studies of fall chinook salmon Oncorhynchus fshawytscha conducted by the National Biological Survey (NBS) and the U.S. Fish and Wildlife Service. Activities were funded by the Bonneville Power Administration (BPA) through funding of Project $92-029$.

The decline in abundance of fall chinook salmon in the Snake River basin has become a growing concern. In April 1992, Snake River fall chinook salmon were listed as "threatened" under the Endangered Species Act. Effective recovery efforts for fall chinook salmon cannot be developed until we increase our knowledge of the factors that are limiting the various life history stages. This study attempts to identify those physical and biological factors which influence spawning of fall chinook salmon in the free-flowing snake River and their rearing and seaward migration through Columbia River basin reservoirs.

Aerial surveys to count fall chinook salmon redds in the Snake River have been made annually since 1987. These flights are index flights and are useful for historical comparison. Index counts of snake River fall chinook salmon redds increased from 32 in 1991 to 40 in 1992, but were still lower than the 1987 high of 66. We began making weekly flights in 1991 to increase the accuracy of redd counts. The 1992 weekly count totalled 45 compared to the 1991 weekly count total of 41 . We also began underwater surveys in 1991 to search for redds in deeper water. There was no conclusive evidence of deepwater spawning found in the free-flowing Snake River or below Lower Monumental Dam in 1992, but the area covered was relatively small and limited to know spawning sites.

The flow and temperature regimes of the snake River were studied to assess the effects of the Hells Canyon Dam on fall chinook salmon spawning and early life history. We found that Hells Canyon Dam shaped the flow pattern of the Snake River downstream to RK 270. The thermal regime of the snake River was colder during egg incubation and fry emergence during the 1992 brood year than during 1991. Our calibrated hydraulic model of RK 261 predicted that the flow required to dewater the shallowest fall chinook redds at RK 261 would be 7.4 KCFS (gaged at RK 2701, which is well below any actual flow event which occurred during fall chinook salmon spawning or egg incubation of 1991 or 1992 . Consequently, the ongoing attempt by the Idaho Power Company to prevent fall chinook salmon redd dewatering by stabilizing flows from Hells Canyon Dam throughout spawning had positive effects in 1992 . 
Migratory behavior of subyearling fall chinook salmon was examined in laboratory swimming performance tests. Subyearling chinook salmon were displaced most rapidly during May and June in a swim flume when they were less than $9 \mathrm{~cm}$ in length and the water temperature was less than $16^{\circ} \mathrm{C}$. During displacement the fish swam upstream at about the optimum velocity of $1 \mathrm{bl} / \mathrm{s}$, or just fast enough to maintain body control. During the peak of emigration, fish are capable of moving substantial distances during the day as well as at night, the time when they usually are displaced the farthest. Fish actively swam downstream only at very low water velocities, when their disposition to migrate was maximum, and rarely drifted in the current.

The use of PIT tags in subyearling fall chinook salmon was evaluated in laboratory tests. In 44-d rearing trials conducted during 1992 mortality due to PIT tagging was 1\%, a reduction from delayed mortality ranging from 7 to 27\% during 1991. Mortality was reduced in 1992 by using an improved tag insertion technique, increasing the minimum size to $60 \mathrm{~mm}$, and the use of a buffered anesthetic with shorter exposure times. Consequently, predation vulnerability was reduced in fish allowed $0.5 \mathrm{~h}$ recovery after PIT tagging in 1992 tests as compared to 1991 tests. Predation of PIT-tagged fish by smallmouth bass Micropterus dolomieui was not size selective. A comparison of U-critical swimming speed of PIT-tagged and control fish allowed to recover for time periods ranging from $0.5 \mathrm{~h}$ to $96 \mathrm{~h}$ indicated that effects from tagging on swimming performance could be as long as $24 \mathrm{~h}$.

Juvenile fall chinook salmon were seined and PIT tagged in the free-flowing snake River to describe rearing patterns, emigration behavior, and emigration timing. We seined 1,309 fall chinook salmon in systematic samples in 1992. Estimated fall chinook salmon fry emergence ranged from 18 March to 25 May with a 25 April peak. We PIT tagged and released 1,100 chinook salmon juveniles of which 947 were considered as fall chinook salmon ( $87 \%$ ) on the basis of post season race separation. We tagged fall chinook salmon in the Snake River from 14 April through 10 June with a 27 May peak. About 7\% of all tagged fall chinook salmon were recaptured by seine; most at the original site of tagging. Mean emigration rate from release sites in Hells Canyon to Lower Granite Dam was $3.6 \mathrm{~km} / \mathrm{d}$ with peak and median dates of passage occurring on 23 and 22 June, respectively. Using multilinear regression we estimated that emigration rate was significantly influenced by temperature, flow, and fish size.

Juvenile fall chinook salmon were seined in the Columbia River in the Hanford Reach and in McNary Reservoir to identify and describe rearing habitats of naturally produced fish. Peak numbers of subyearling chinook salmon were captured during May in all reaches, but as water temperatures increased above $15.9^{\circ} \mathrm{C}$, mean catch decreased. Columbia River subyearling chinook salmon 
emerged earlier and remained smaller than snake River subyearlings. Subyearlings were caught in significantly greater numbers during the day than during the night. Most subyearlings were caught in shallow water between $0.5 \mathrm{~m}$ and $2.0 \mathrm{~m}$ deep. Substrate did not appear to have an influence on catch of subyearling chinook salmon in the main stem Columbia River.

Subyearling fall chinook salmon were marked at McNary Dam to relate river flow and migration patterns of juvenile salmon to adult returns. A total of 105,250 fish emigrating during the early, middle, and late segments of the migration were successfully coded wire tagged and released at McNary Dam. Delayed mortality and tag loss ranged from 0.6 to $0.7 \%$ and was considered acceptable. Adequate numbers of branded fish were recaptured at John Day and Bonneville dams to determine that the three groups of fish maintained their integrity and emigrated separately in relation to when they were released. Travel time of subyearling chinook salmon through John Day Reservoir was not significantly correlated with any of the variables tested. Subyearling chinook salmon marked at McNary Dam appeared to be fully smolted and were physiologically adapted to seawater as measured in $24 \mathrm{~h}$ seawater challenges. Gill ATPase activity declined toward the latter portion of the emigration in control fish but remained elevated in seawater challenged fish. 


\section{ACKNOWLEDGEMENTS}

We thank individuals in the Idaho Department of Fish and Game, Idaho Power Company, U.S. Fish and Wildlife Service, Washington Department of Fisheries, Washington Department of Wildlife, U.S. Army Corps of Engineers, National Marine Fisheries Service, and the Fish Passage Center that assisted with the project activities. We extend special thanks to our colleagues at the Columbia River Research Laboratory of the National

Biological Survey and the Idaho Fishery Resource Office of the U.S. Fish and Wildlife Service for their assistance. We gratefully acknowledge reviewers for the valuable comments and suggestions which we have incorporated into this report. We appreciate the assistance of Debbie Watkins, Project Manager, Bonneville Power Administration. 


\title{
CHAPTER ONE
}

Fall Chinook Salmon Spawning

Ground Surveys in the Snake River

\section{by}

\begin{abstract}
A.P. Garcia, and W.P. Connor U.S. Fish and Wildlife Service Idaho Fishery Resource Office Ahsahka, Idaho 83520, USA
\end{abstract}

and

\author{
R.H. Taylor \\ U.S. Forest Service \\ Clearwater National Forest \\ Orofino, Idaho 83544, USA
}


Introduction

The number of fall chinook salmon Oncorhynchus tshawytscha spawning in the free-flowing reach of the snake River declined dramatically over the past two decades (Irving and Bjornn 1981; Witty 1988; Seidel et al. 1988; Bugert et al. 1989, 1990). As a result, in 1992, Snake River fall chinook salmon were added to the federal list of threatened species (NMFS 1992). This listing increased the need for data on snake River fall chinook salmon spawning escapement and habitat.

Our 1992 work was a continuation of research we began in 1991 (Connor et al. 1993). Our objectives in 1992 were to: (1) describe the distribution of fall chinook salmon redds in the Snake River; (2) use underwater and ground searches at study sites to improve the accuracy of aerial redd counts; and (3) assess fall chinook spawning in the tailrace of Lower Monumental Dam.

\section{Study Area}

The study area included the Snake River from Hells Canyon Dam to its mouth (Figure 1). We describe specific locations within the area in terms of river kilometers (RK) based on U.S. Army Corps of Engineers (COE) navigation charts of the Snake River (COE 1990) and U.S. Geological Survey topographical maps. Much of our work in 1992 was done in the free-flowing reach of the Snake River between Hells Canyon Dam (RK 398) and the head of Lower Granite Reservoir near Asotin, Washington (RK 235). Additional work was conducted within $1 \mathrm{~km}$ downstream of Lower Monumental Dam (RK 67).

\section{Methods}

\section{Data Collection}

Redd counts.-Fall chinook salmon redd count data were collected by helicopter from 1987-1992 (Seidel et al. 1988, Bugert et al. 1989, 1990, 1991, Bugert 1991, and Mendel et al. 1992). From 1987-1989, aerial counts of fall chinook salmon redds were made about the second and fourth weeks of November. In 1990, based on an interagency consensus, we added a third count in early December to check for late fall chinook salmon spawning activity. These aerial counts are useful for historical comparison and are referred to hereafter as "index counts". Each index count covered the river from Asotin, Washington (RK 235) to Hells Canyon Dam (RK 398), unless the weather became inclement. The river was scanned for fall chinook salmon redds by observers while the helicopter flew at an altitude of 100 to $200 \mathrm{~m}$. When 


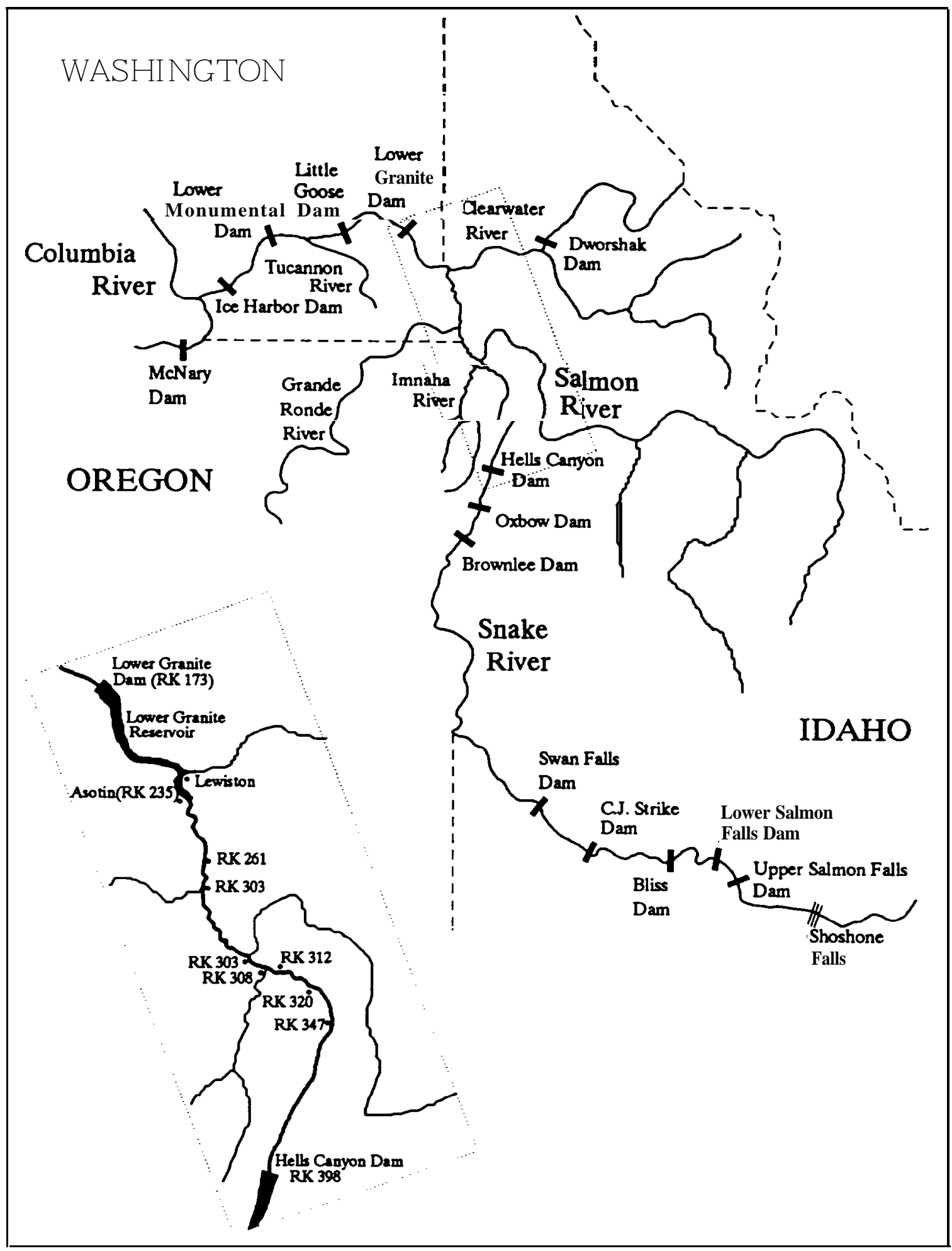

Figure 1.-Map of the Snake River drainage showing Lower Monumental Dam at RK 67, and mset showing fall chinook salmon spawning study sites at RK 261, RK 312, and RK 320, and Lower Granite Dam at RK 173, and the head of Lower Granite Reservoir near Asotin, Washington at RK 235. 
a potential redd was located, the pilot positioned the helicopter for optimal viewing and an observer noted the location of the potential redd on $\mathrm{COE}$ navigation charts. The authenticity of potential redds observed during index counts was judged from the air.

Refinements in redd counts. -In addition to index counts, "weekly" counts of new redds were made by aerial survey in $\mathbf{1 9 9 1}$ and 1992, to improve count accuracy and define the timing of fall chinook salmon redd construction. In 1991, 9 counts of new redds were made by aerial surveys at $6 \mathrm{~d}$ to $8 \mathrm{~d}$ intervals from 14 October to 9 December. In 1992, 8 counts were made at 6 d to 11 d intervals from 16 October to 12 December. Weekly redd counts were made on the same flights that index counts were made on, but weekly counts were adjusted based on ground verification.

In 1992, all potential fall chinook salmon redds observed during aerial surveys were authenticated by ground truthing. Ground truthing involved viewing each redd from a position upstream and to the side of the suspected redd. The authenticity of each redd was determined based on the dimensions of the disturbed area, substrate composition, water velocity, presence of adult salmon, and the use of the area by spawning fall chinook salmon in previous years.

Underwater searches for fall chinook salmon redds were conducted in water too deep for air or ground detection. In 1991, RK 261 was the only site searched (Connor et al. 1993). In 1992, searches were made at RK 261, RK 312, and RK 320. The locations of shallow-water redds at these sites were recorded by a surveyor sighting a hand-held prism positioned over the redds by wading or boat. Buoys were then used to mark the mid-channel edge of the shallow water-redds and to establish navigation lanes in deeper water parallel to the flow. Underwater searches were made along the navigation lanes by towing a sled operated by two divers equipped with SCUBA. The divers searched for redds as they were towed upstream by the boat. The first pass at each site was run parallel to the buoys positioned near the edge of shallow-water redds; subsequent passes were initiated progressively toward mid channel. Divers scanned the river bed for redds and radioed the boat crew when redds were observed. The boat crew relayed the redd observation to a surveyor who sighted the position of a pontoon equipped with a prism array that was towed directly above the divers.

Surveys in the Lower Monumental Dam tailrace.-Substrate data were collected using an underwater camera in the tailrace of Lower Monumental Dam in mid November, 1992. The camera was attached to a $28 \mathrm{~kg}$ sounding weight which was lowered from a boat to an elevation about $60 \mathrm{~cm}$ above the bottom. The substrate was observed by surface monitor and recorded on video tape. Video 
observation locations were tracked by surveying a prism mounted on the boat directly above the camera. Once a video record was obtained at a location, the camera was raised and the boat moved to a new location and the process repeated. Dominant and subdominant substrate particle sizes were estimated on a video monitor using a modified Brusven index and a calibrated measuring tape (Brusven 1977; Table 1); percent fines were not estimated from video records. Dominant substrate size ranges were mapped to show the general substrate composition within the surveyed area.

Table I.-Substrate code, description, and size range used to estimate substrate composition in the snake River (modified from Brusven 1977).

\begin{tabular}{|c|c|c|c|}
\hline \multirow[t]{2}{*}{ Code } & \multirow[t]{2}{*}{ Description } & \multicolumn{2}{|c|}{ Size Ranse } \\
\hline & & inches & $\mathrm{cm}^{\mathrm{a}}$ \\
\hline 0 & Fines & $\leq .25$ & $\leq .65$ \\
\hline 1 & Small Gravel & $.25-1$ & $.65-2.5$ \\
\hline 2 & Medium Gravel & $1-2$ & $2.5-5.0$ \\
\hline 3 & Large Gravel & $2-3$ & $5.0-7.5$ \\
\hline 4 & Small Cobble & $3-6$ & $7.5-15-0$ \\
\hline 5 & Medium Cobble & $6-9$ & $15.0-23-0$ \\
\hline 6 & Large Cobble & $9-12$ & $23-0-30.5$ \\
\hline 7 & Small Boulder & $12-24$ & $30-S-61.0$ \\
\hline 8 & Large Boulder & $>24$ & $>61.0$ \\
\hline 9 & Bedrock & & \\
\hline
\end{tabular}

\footnotetext{
a Metric size ranges are converted from english units and rounded to the nearest $0.5 \mathrm{~cm}$.
}

Underwater redd searches and additional substrate surveys were made in the tailrace of Lower Monumental Dam on 17 and 18 November to test the effectiveness of SCUBA diving while water was being released through Lower Monumental Dam turbines. The underwater search methods used in these November dives were similar to those we used in the free-flowing snake River and described previously.

A second search of the Lower Monumental Dam tailrace was made on 16 December under static ("zero-flow") conditions. Methods used for diving under zero-flow conditions were different than those used when the dam was releasing water. The boundary of the selected area was marked with four surface floats to form a rectangle with two sides roughly parallel with the shoreline. Ropes were attached between the upstream and downstream float anchors on two sides of the rectangle to form two submerged lines parallel with the shoreline. Two divers searched for redds along 
transects $2 \mathrm{~m}$ apart as they swam side-by-side above the river bed until they reached the submerged rope on the opposite side of the rectangle. Progress along the submerged ropes was marked and recorded by surveying a prism positioned over the submerged ropes by boat each time the divers moved to a new starting location. In addition, the general path of the divers was tracked while swimming between the submerged ropes by surveying a prism positioned over the diver's exhaled bubbles. Divers maintained contact with the surface crew using voice-activated radios.

\section{Data Analysis}

Redd counts.-Data from air, ground, and underwater surveys are summed to show fall chinook salmon redd counts by year, day, and RK from 1987-1992. We used the first two index counts of each year to compare redd counts between years.

Refinements in redd counts.-Redd construction timing was analyzed from weekly redd counts and compared to index counts from 1991 and 1992. In addition, we compared the results of aerial counts, ground truthing, and underwater observations at RK 261 to evaluate the effectiveness of each technique.

Surveys in the Lower Monumental Dam tailrace.-We mapped the substrate composition of areas searched by camera and SCUBA divers in the tailrace of Lower Monumental Dam to show areas containing substrate that is potentially suitable for spawning.

Results

\section{Redd Counts (I 987-l 992)}

The first two index counts in 1992 totalled 39 and one additional redd was counted on the third index count for a total of 40 redds (Table 2). Thirty two redds were counted during the three index counts of 1991 (Table 2). The sum of the first two index counts collected between 11 November and 1 December, 19871991 ranged from 66 to 31 (Figure 2).

Since 1987, redds have been observed from RK 240.5 to RK 396.6 (Table 2, Figure 3). In 1992, redds were distributed between RK 245 and RK 353 (Table 3). Based on all three index counts, 70\% of the redds counted in the Hells Canyon reach in 1992 were located downstream of the Grande Ronde River (RK 271). The largest concentration of redds above the Grande Ronde River was 6 redds near RK 312. The largest concentrations of redds below the Grande Ronde River were 7 redds near RK 245, 7 redds at RK 259, and 9 redds at RK 261.3. 
Tabl e 2. -River kiloneter (RK), landmark, and fal I chi nook sal non redd index counts from the Snake Ri ver, 1987-1992 (from Sei del et al.1988; Bugert et al. 1989, 1990, 1991; USFUS fi l es).

\begin{tabular}{|c|c|c|c|c|c|c|c|c|c|c|c|c|c|c|c|c|c|}
\hline & & 198 & & & 88 & 19 & & & 1990 & & & 1991 & & & 1992 & & - Site \\
\hline RK & Landmark & 09-Nov & 3-Nov & -Nov & 01- Dee & 13-Nov & 27-Nov & 12-Nor & 26-Nov & 11- Dee & 11- Nov & 26-Nov & 09-Dec 1 & 13-Nov 2 & 23-Nov 1 & 12-Dec & Total \\
\hline 240.5 & Ten M le Rapi ds & - & & & - & & 1 & 1 & - & - & 1 & - & - & - & - & - & 3 \\
\hline 244. 4 & Ten MIe Canyon & - & & & 1 & & 1 & $\cdot$ & - & - & 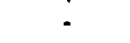 & - & - & - & - & - & 2 \\
\hline 245. 2 & Bi g Bench Poi nt & - & 13 & 4 & 4 & 20 & 3 & 8 & 4 & 4 & - & - & - & 1 & 6 & - & 67 \\
\hline 252.6 & Uarehouse at Couse Crk & - & & & - & & 1 & - & 1 & $\cdot$ & - & - & - & - & - & - & 2 \\
\hline 257. 1 & Lower Buff al o Range & - & & & - & & - & - & - & - & - & - & - & 2 & 1 & - & 3 \\
\hline 258. 9 & Below Upper Buffal o & - & & & - & & - & - & - & - & - & - & - & 1 & - & - & 1 \\
\hline 259.0 & Upper Buf fal o Rapi ds & - & & & - & & - & - & - & - & - & - & - & 6 & 1 & - & 7 \\
\hline 261. 3 & Captai n J ohns Creek & - & & & - & 1 & - & - & 2 & - & 11 & 3 & - & 5 & 4 & - & 26 \\
\hline 262.6 & Captai n John Rapi ds & - & 3 & & 2 & & - & 2 & - & - & $\cdot$ & - & - & $\cdot$ & $\cdot$ & - & 7 \\
\hline 265.0 & Bi II y Creek Rapi ds & 2 & & 5 & 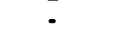 & 1 & 1 & - & - & 1 & - & - & - & - & - & - & 10 \\
\hline 266. 0 & Fi sher Gul ch & - & 4 & & - & & - & - & - & - & - & - & - & - & - & - & 4 \\
\hline 266. 6 & Upper Bi IIy Creek Rapi d & - & 2 & 10 & 4 & & - & - & - & - & - & - & - & - & 1 & - & 17 \\
\hline 268. 1 & Louer Lewis Rapi ds & - & & & - & & - & - & - & - & $\cdot$ & 3 & - & - & $\cdot$ & - & 3 \\
\hline 272.7 & Near Leui s Poi nt & - & & & - & 1 & - & - & - & - & - & - & - & - & - & - & 1 \\
\hline 277.6 & Deer Head Rapi ds & - & 1 & & - & & - & - & - & - & - & - & - & - & - & . & $i$ \\
\hline 279.8 & Below Shovel Creek & - & 1 & & - & & - & - & - & - & - & - & - & - & - & - & 1 \\
\hline 287.9 & Cochran Is land Mead & - & & & - & 1 & - & - & - & - & - & - & - & - & - & - & $i$ \\
\hline 307.3 & Eureka Bar & - & 1 & 1 & 4 & & - & 2 & - & - & 1 & 2 & - & - & - & 1 & 12 \\
\hline 308.4 & Near Imnaha Ri ver & - & 2 & & 4 & & - & - & - & - & - & - & - & $\cdot$ & $\cdot$ & - & 6 \\
\hline 311.0 & Above Di vi de Creek & 4 & & & - & 5 & - & - & 2 & - & - & - & - & - & - & - & 11 \\
\hline 311. 7 & Di vi de to Zig Zag & - & & & - & & - & - & 3 & - & - & - & - & 5 & 1 & - & 9 \\
\hline 312.3 & Above Zig Zag Creek & - & 2 & & 2 & & - & - & 2 & - & - & - & - & - & : & - & 6 \\
\hline 315.7 & Below Dug Bar, OR & 1 & & & 3 & & - & $\cdot$ & - & - & - & - & - & - & - & - & 4 \\
\hline 319.9 & Above Robi nson Gulch & - & 1 & & 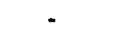 & & - & 2 & - & - & - & 4 & $\cdot$ & - & 3 & - & 10 \\
\hline 320.0 & Bel ow Deep Creek & 4 & & & - & 3 & - & - & - & - & - & - & - & - & $=$ & - & 7 \\
\hline 328.4 & Near Bl ankenshi p Ranch & - & 1 & & - & & - & $\cdot$ & $\cdot$ & - & - & - & - & - & - & - & 1 \\
\hline 330.2 & Above Copper Creek & - & & & - & & - & - & - & - & - & 2 & 1 & - & - & - & 3 \\
\hline 330.8 & Below Getta Creek & $\cdot$ & 1 & & - & & - & - & - & - & - & - & $\cdot$ & - & - & - & 1 \\
\hline 332.1 & Bel ow H gh Range Nb. 1 & 1 & & 3 & 1 & & - & - & - & - & 1 & - & - & 1 & 1 & - & 8 \\
\hline 334.4 & Near Lookout Creek Range & - & & $\cdot$ & 1 & & - & $\cdot$ & - & - & - & - & $\cdot$ & - & - & - & 1 \\
\hline 334. 5 & Below Lookout Creek & - & & 2 & $\cdot$ & 1 & - & - & - & - & - & - & - & - & - & - & 3 \\
\hline 337.4 & Bel ow Camp Creek & - & 1 & $=$ & - & & - & - & - & - & - & - & - & - & - & - & 1 \\
\hline 343. 7 & Pl easant Val I ey Creek & - & & $\cdot$ & - & & 2 & - & 1 & - & - & - & - & - & - & - & 3 \\
\hline 345.5 & Near Pi ttsburg Range & 2 & & - & - & & - & - & - & - & - & - & - & - & - & - & 2 \\
\hline 350.4 & Durham Rapi ds & $=$ & & - & - & 1 & - & - & - & - & - & - & - & - & - & - & 1 \\
\hline 351. 1 & Below Cat Gulch & 1 & & - & - & & - & - & - & - & - & - & - & - & - & - & 1 \\
\hline 352.9 & K rby Range & - & & 2 & - & & - & - & - & - & - & - & - & - & - & - & 2 \\
\hline 358.5 & Near Sui ci de Rock & 3 & & & - & 4 & - & - & - & - & - & - & - & - & - & - & 7 \\
\hline
\end{tabular}


Tabl e 2. (Conti nued) .

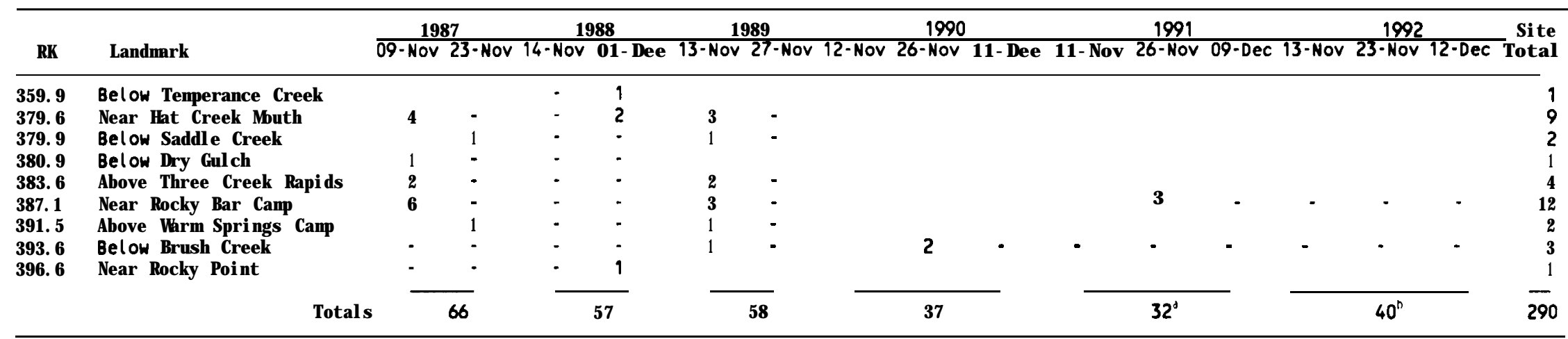

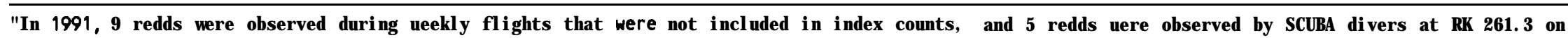
26 Novenber that were not observed by ai $r$.

"In 1992 an addi ti onal 6 redds uere observed but not consi dered redds during the 23 Novenber i ndex count, then val i dated by ground truthi ng: 2 at RK 266. 6, 2 at RK 344. 0, 1 at RK 349.6, and 1 at RK 352.9; I n addi ti on, 2 redds uere first observed then val idated by boat at RK 261. 3 after 12-Decenber 92. 


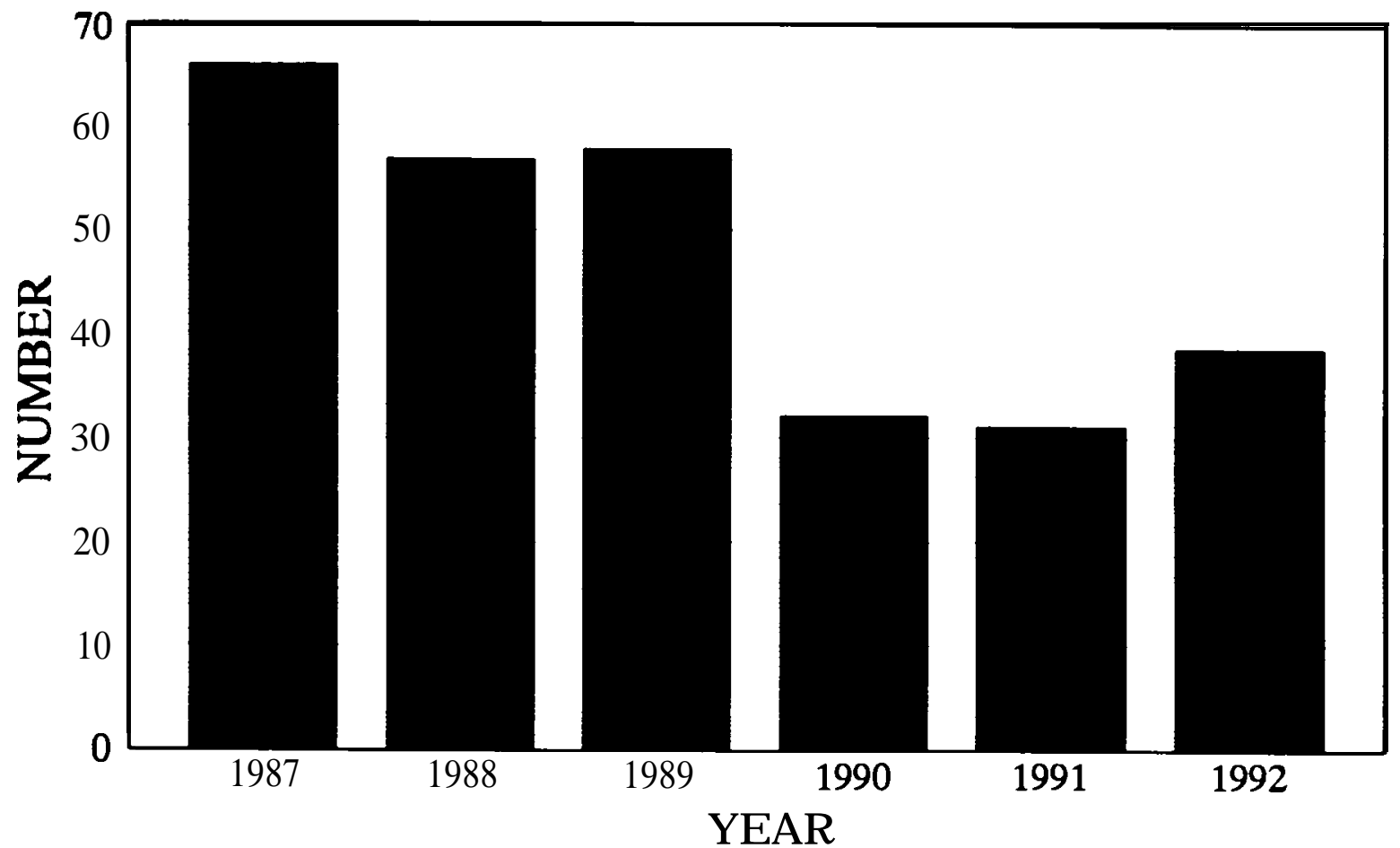

Figure 2.-Index counts of fall chinook salmon redds collected between 11 November and 1 December, 1987-1992.

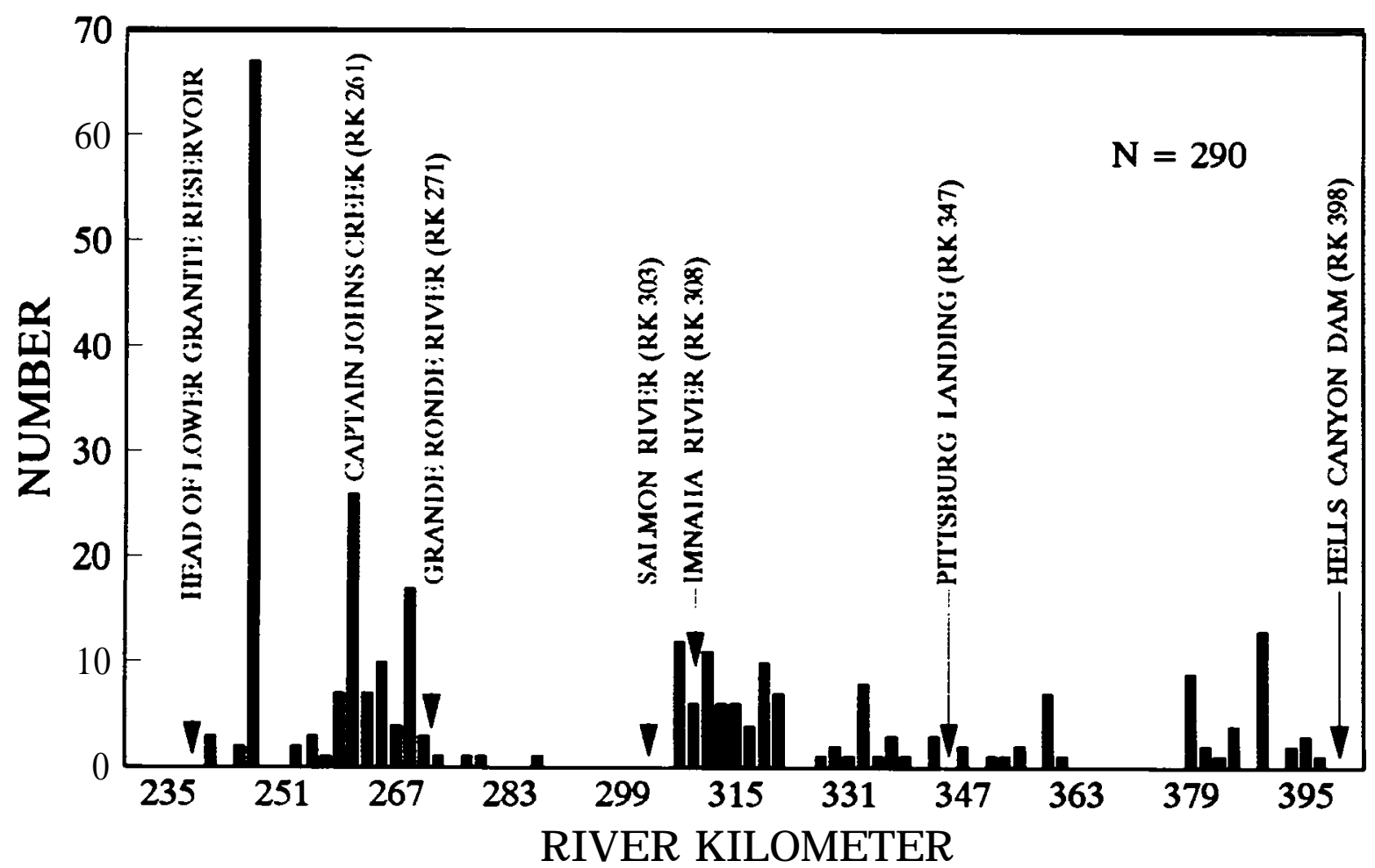

Figure 3.-Number of fall chinook salmon redds by river kilometer from index counts on the Snake River 1987-1992 (Seidel et al. 1987, Bugert et al. 19891991, Bugert 1991, Mended et al. 19992, and Mendel, m press). 
Table 3.-River kilometer (RK), landmark, and new fall chinook salmon redds counted by date during aerial surveys of the Snake River in 1992.

New redds counted by flight date"

RK Landmark 16-Oct 23-Oct 30-Oct OS-Nov 13-Nov 23-Nov 04-Dec 12-Dec Totals

245.2 Big Bench Point

257.1

259.0

261.3

266.6

307.3

311.7

319.9

$-\quad 332.1$

344.0

349.6

352.9

Lower Buffalo Range

Upper Buffalo Rapids -

Upper Billy Creek -

Eureka Bar

Divide to Zig Zag

Above Robinson Gulch -

Below High Range

Lower Pleasant Rapid -

Coral Creek Reef

Kirby Range

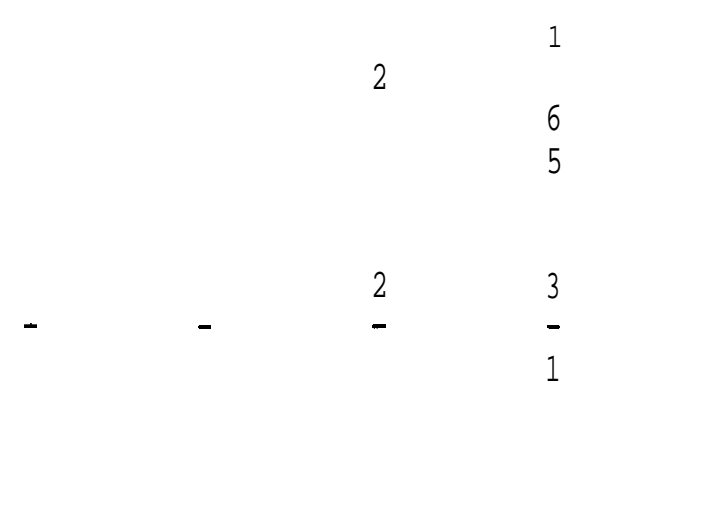

$\begin{array}{llll}6 & & & 7 \\ 1 & & & 3 \\ 1 & & & 7 \\ 4 & & & 9 \\ 1 & 2 & 1 & 3 \\ & & & 1 \\ 1 & & & 3 \\ 3 & & & 2 \\ 1 & & 2 \\ & 2 & & 1 \\ & 1 & & 1 \\ & 1 & & \end{array}$

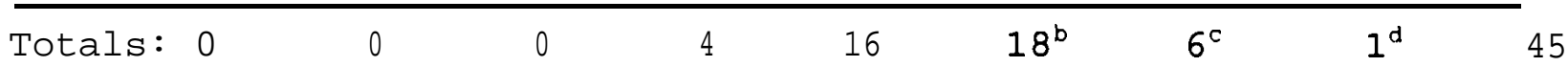

"The flight on 16 October covered from Pittsburg Landing (RK 347) to Asotin, Washington (RK 235), and the flight on 30 October covered from Asotin to Cochran Islands (RK 288).

"one potential redd was observed at RK 258.9 that was judged to be a redd from the air and therefore included in the index count for 13 November, but was not validated by ground truthing.

"The 6 redds counted on 4 December were observed but not considered redds during the 12 December index count,

then validated by ground truthing.

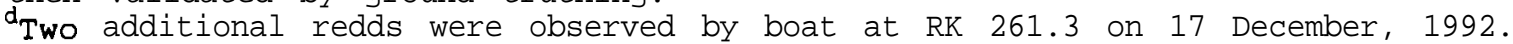




\section{Refinements in Redd Counts}

In 1992, a total of 47 redds were counted in the Hells Canyon reach of the Snake River (Table 3). Weekly aerial redd counts totalled 45, and 2 additional redds were counted from the ground after the last aerial survey. The first redd was counted by aerial survey on 5 November, redd counts peaked on 23 November, and the last redd was counted on 12 December (Figure 4). In 1991, the first redd was counted by aerial survey on 28 October, the highest count was on 18 November, and the last new redd was counted on 9 December (Figure 5).

Six gravel disturbances observed during aerial surveys in 1992 were not judged to be redds from the air, but were subsequently determined to be fall chinook salmon redds by ground truthing. In addition, one gravel disturbance was judged to be a redd from the air on the 13 November index count, but was not verified by ground truthing. These redds account for the difference in weekly aerial counts (45) and index counts (40) in 1992 .

Multiple dive passes were made on the deepwater edge of surveyed redds at RK 261 (Figure 6), RK 312, and RK 320. No redds were observed by SCUBA divers in deepwater areas at these sites in 1992 .

\section{Surveys in the Lower Monumental Dam Tailrace}

We mapped roughly 4,000 $\mathrm{m}^{2}$ of substrate, dominated by particles $2.5 \mathrm{~cm}$ to $15.0 \mathrm{~cm}$ in diameter, within the surveyed site in the tailrace of Lower Monumental Dam (Figure 7). About 7,100 $\mathrm{m}^{2}$ of substrate dominated by $15.0 \mathrm{~cm}$ particles was also mapped. Areas having a dominant substrate greater than $15.0 \mathrm{~cm}$ contained pockets of substrate with area and particle size that appeared acceptable for spawning. Despite the presence of suitable substrate, no fall chinook salmon redds were identified during underwater surveys in the vicinity of the proposed dredge area in 1992 (Figure 8). 


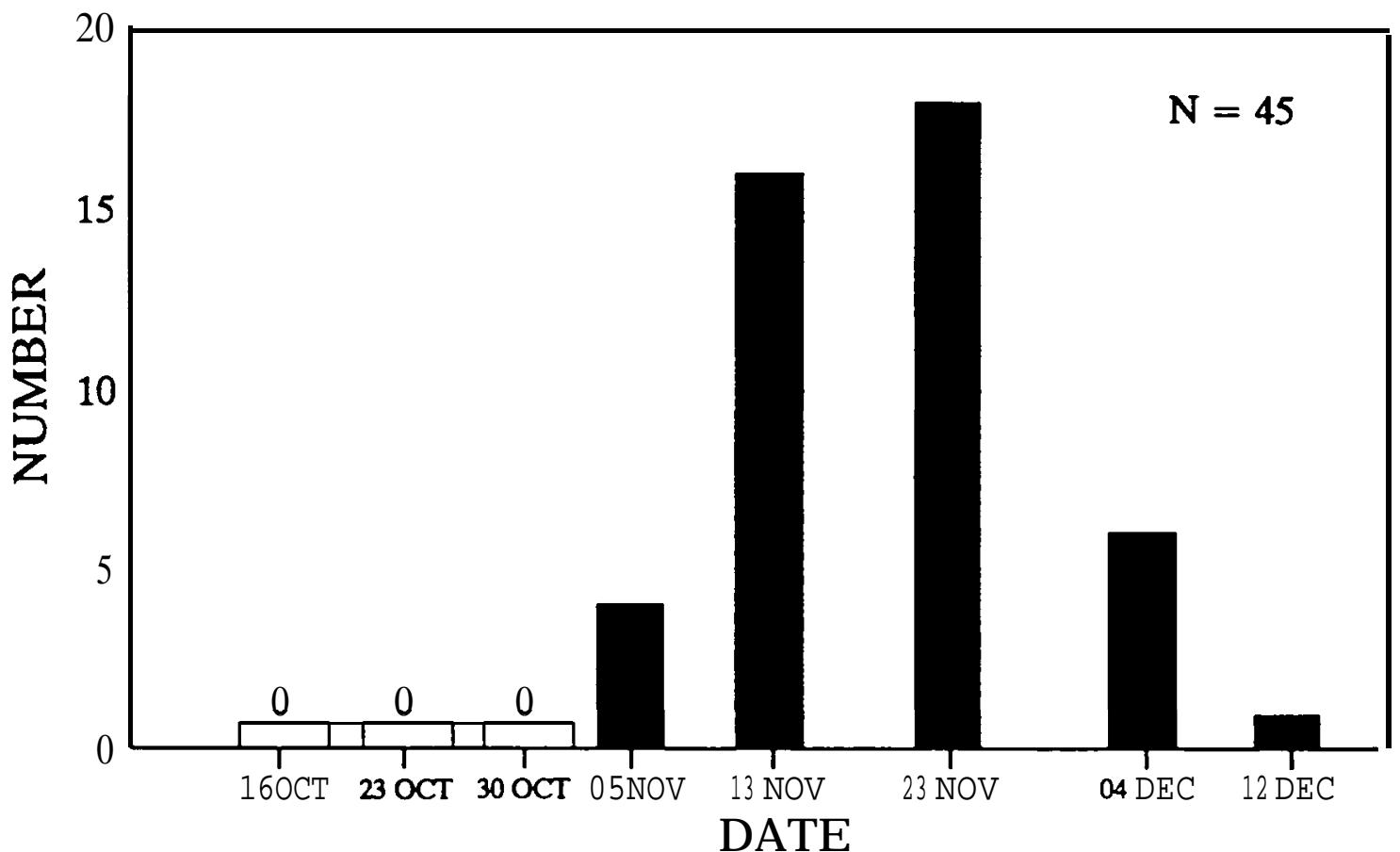

Figure 4.-Number of new fall chinook salmon redds counted on aerial surveys of the Snake River, 1992 (Data from Mendel, in press).

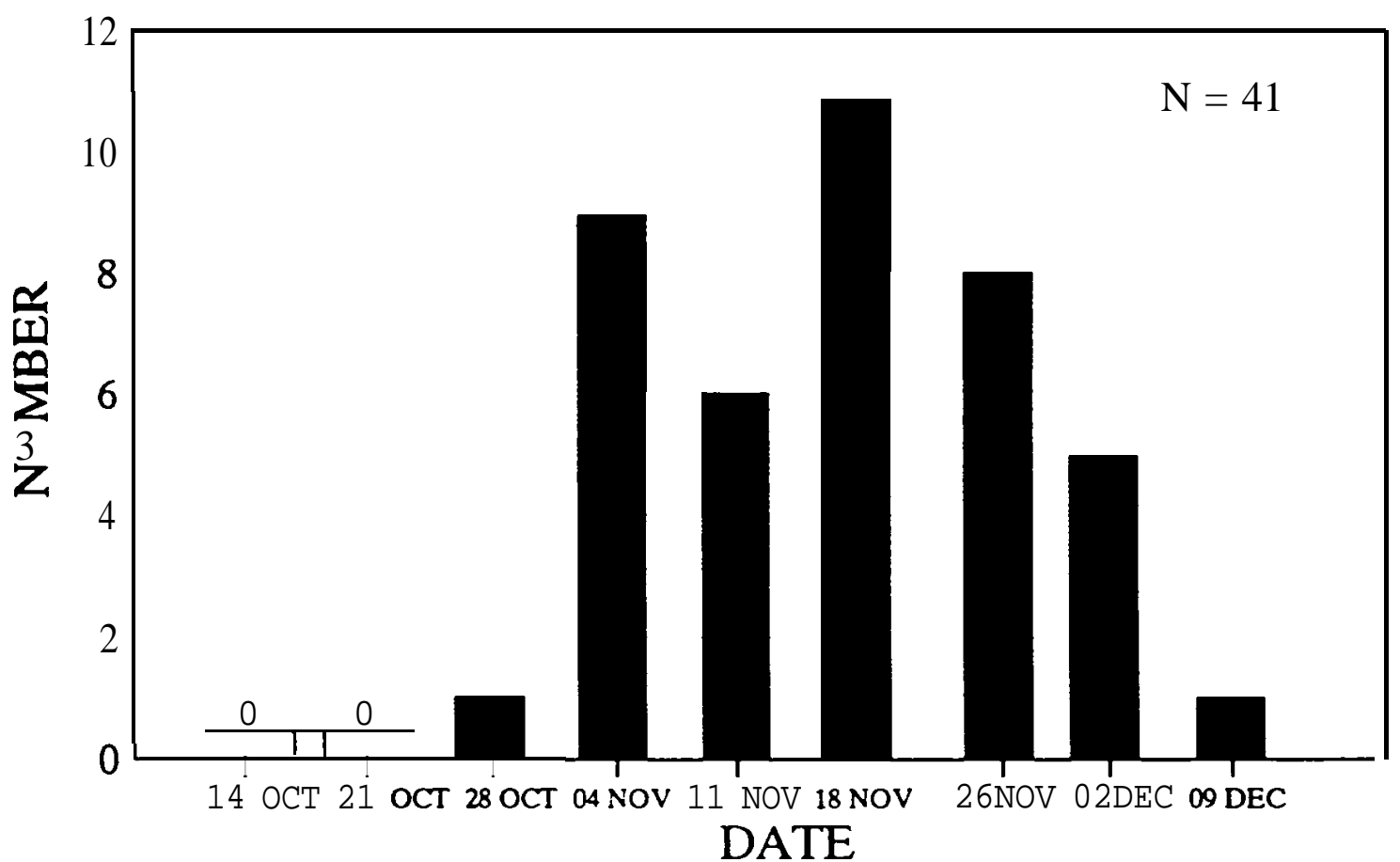

Figure 5.-Number of new fall chinook salmon redds counted on aerial surveys of the Snake River, 1991 (Data from Connor et al. 1993). 


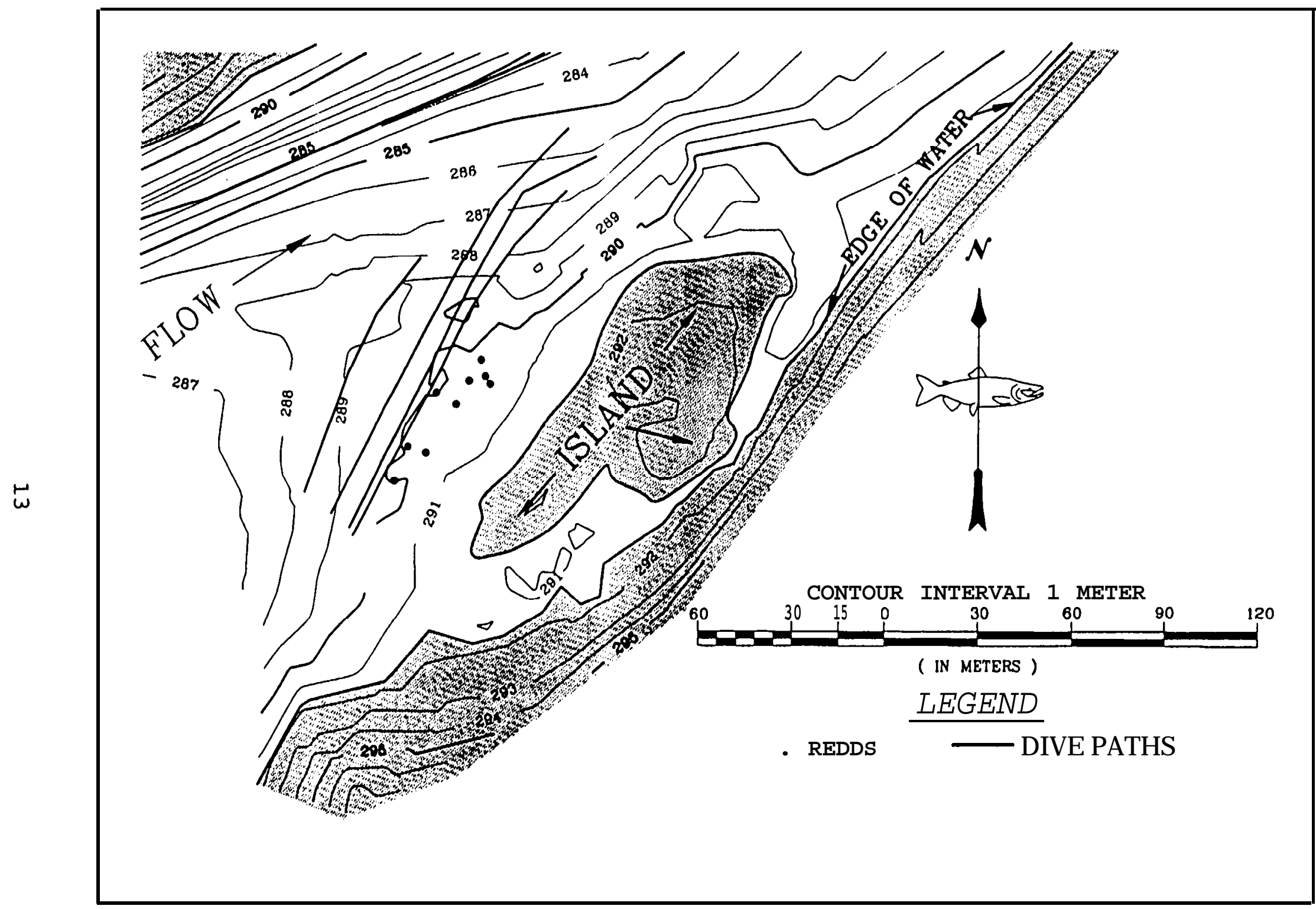

Figure 6.- Fall chinook salmon redd locations and SCUBA diver paths at RK 281 in December, 1992. 


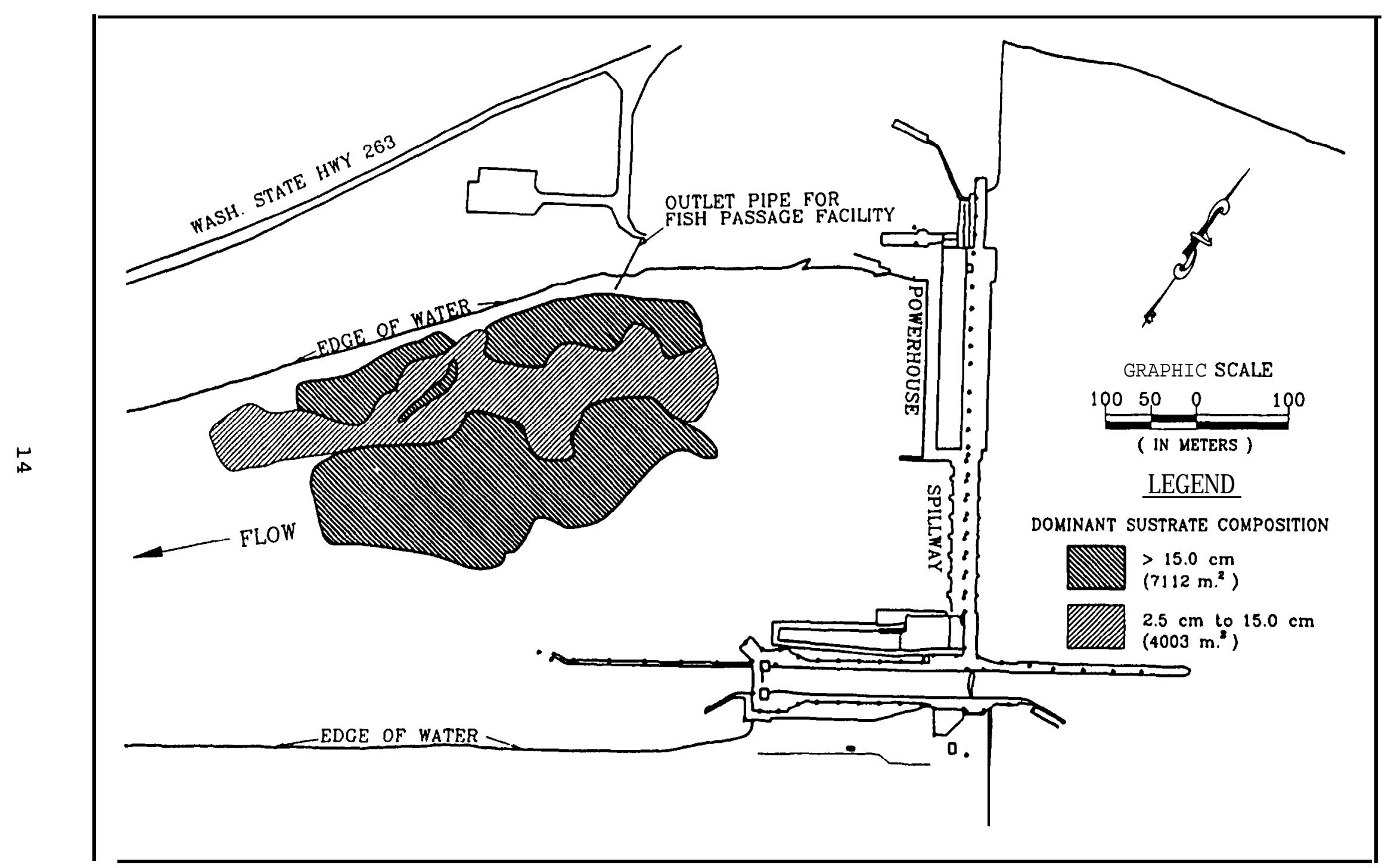

Figure '7. - Distribution of dominant substrate determined by camera then scuba divers in the tailrace of Lower Monumental Dam , October and December 1992. 


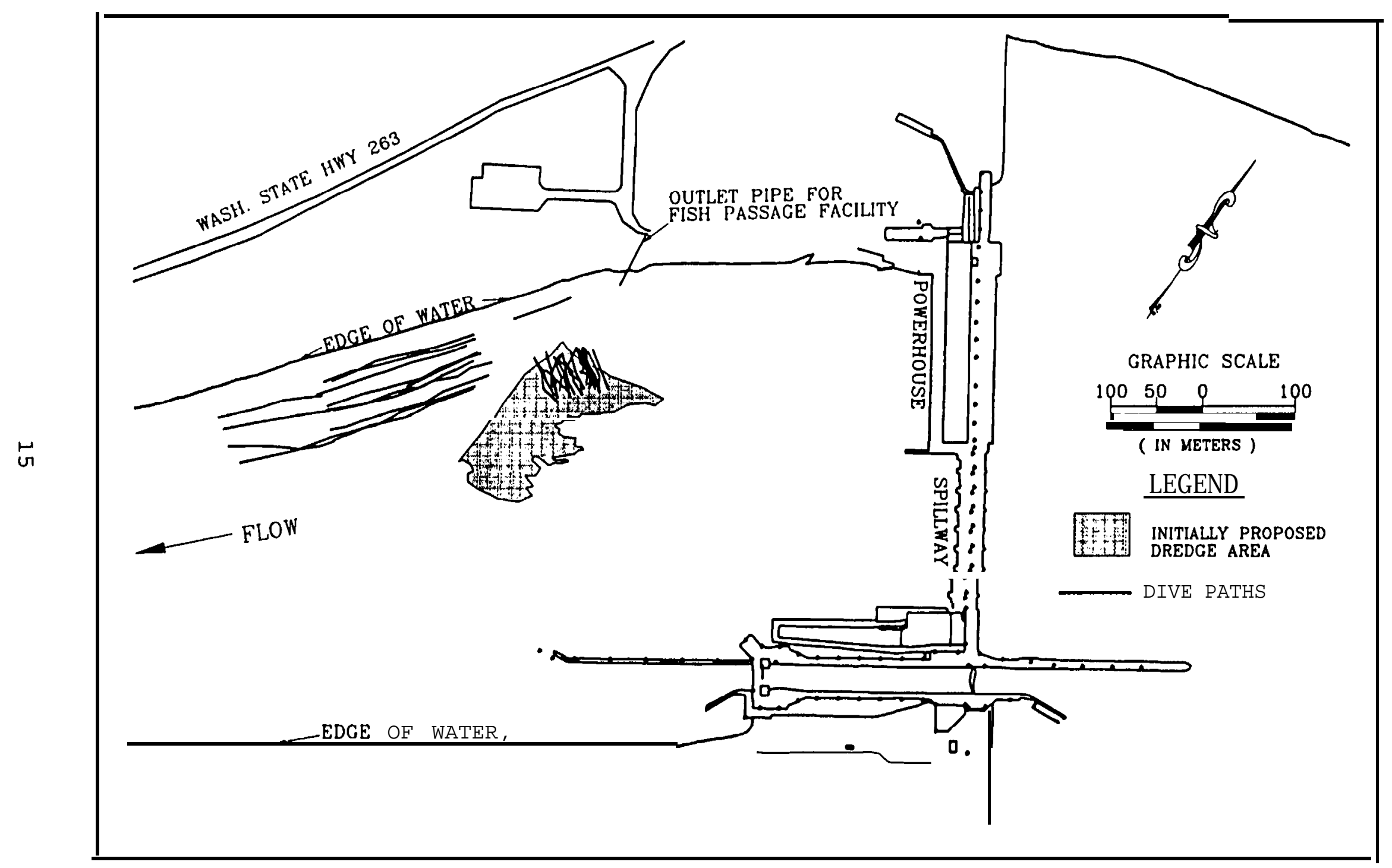

Figure 8. - Scuba diving paths through and below the proposed dredge area in Lower Monumental Dam tailrace, November and December 1992. 


\section{Discussion}

Fall chinook salmon redd distribution in the Snake River shifted within the first few years after the completion of Hells Canyon Dam (Connor et al. 1993). In the early years after the completion of the dam, fall chinook spawned mostly in the upper third of the free-flowing snake River. From 1987-1991, most spawning occurred in $31 \mathrm{~km}$ of free-flowing below the mouth of the Grande Ronde River (RK 271). During index counts in 1992, we observed $70 \%$ of the redds within the lower $31 \mathrm{~km}$ of the freeflowing Snake River. In some years, the disproportionate redd distribution in the lower river was due to concentrated spawning at a single site. This was evident in 1991 when $44 \%$ of the redds from index counts were located at RK 261. Conversely, in 1992, the majority of redds were distributed between three sites located below RK 262, and one upriver site above the mouth of the Imnaha River (RK 308) at RK 312 .

Based on weekly redd count data, fall chinook salmon spawning in 1992 appears to have started later and lasted longer than in 1991. Generally, fall chinook salmon spawning in the Snake River is a November event with some spawning in late October and early December (Connor et al. 1993). In 1992, fall chinook salmon spawning in the snake River appears to have begun in early November, peaked in the second or third week of November, and lasted well into the second, if not third, week of December.

Accuracy of fall chinook salmon redd counts by aerial survey is partially affected by observation conditions (e.g., turbidity, discharge, and cloud cover) as well as the frequency of flights; the ability to discern redds from the surrounding river bed becomes more difficult with time. In 1991, we recorded fewer redds in index counts than weekly counts primarily as a result of the longer duration between index counts. In 1992, all of the redds that were recorded in weekly counts were observed during index counts, although some were not judged to be redds from the air. The increased effectiveness of the index counts was likely due to more favorable observation conditions experienced in 1992 as compared to 1991.

The extent of deepwater spawning varied between 1991 and 1992. In 1991, we found at least five redds during underwater searches at RK 261 that had not been detected by aerial survey and ground truthing (Connor et al. 1993). In 1992, the only indication of undocumented spawning at RK 261 was found by Groves (1993). Using an underwater camera, Groves observed an area of disturbed gravel in $2 \mathrm{~m}$ of water that he concluded was a fall chinook salmon redd. 
Deepwater spawning upstream of Lower Granite Dam (RK 173) has been identified as a source of discrepancy in the ratio of adult fall chinook salmon counts at Lower Granite Dam and the number of redds counted upstream (Connor et al. 1993) The adult-per-redd ratio has averaged $10.6 / 1$ (range, $7.4 / ;-15.9 / 1$ ) from 1988-1992 based on index counts and redds counted in tributaries (Mendel et al. 1992, 1993). This average is reduced when deepwater redds are taken into account. To illustrate the degree in which deepwater spawning may influence adult-per-redd ratios, Connor et al. (1993) expanded index counts by 25\% to reflect the number of deepwater redds at found RK 261. By doing so, the average adult-per-redd ratio (1988-1992) is reduced to 8.4/1. Although the extent of undetected deepwater spawning may be greater than was observed at RK 261 in 1991, Mendel et al (1993) reported data on radio-tagged fall chinook salmon that suggests the main source discrepancies in adult-per-redd ratios may be a result of fall chinook salmon moving back downstream after they are counted passing Lower Granite Dam.

Fall chinook spawning below Lower Monumental Dam was confirmed in February 1992 when salmon eggs and fry were found in dredged spoils in the tailrace (Kenney 1992). Surveys of substrate by underwater video camera, done prior to November 1992 in the tailrace of Lower Monumental Dam, showed suitable substrate existed for fall chinook salmon spawning. However, during fall chinook salmon redd surveys in November, underwater visibility was less than $0.5 \mathrm{~m}$, limiting our ability to search for redds. Stopping water flow through the dam combined with improved underwater visibility $(>2 \mathrm{~m})$ allowed a more thorough redd survey in December, but new problems were encountered. Dredge disturbances on the river bed resembled fall chinook salmon redds and the repeated flushing of the dam's lock kept the dredged area free of periphyton and silt. Consequently, we did not find conclusive evidence of fall chinook salmon spawning in the tailrace of Lower Monumental Dam in 1992.

In summary, index counts of Snake River fall chinook salmon redds increased from 32 in 1991 to 40 in 1992. Weekly counts in 1992 totalled 45 compared to 41 in 1991. There was limited evidence of deepwater spawning found in the free-flowing snake River, but no redds were found below Lower Monumental Dam. Notably, the area covered in both the free-flowing snake River and below Lower Monumental Dam was relatively small and limited to known spawning sites. 


\section{References Cited}

Brusven, M-A., 1977. Effects of sediments on insects. Page 43 in D.C. Kibbee, editor. Transport of granitic sediments in streams and its effects on insects and fish. USDA Forest Bulletin 17. Northwest Forest and Range Experimental Station, University of Idaho, Moscow.

Bugert, R. 1991. Fall chinook natural production in the Snake River and tributaries. Washington Department of Fisheries, Memorandum submitted to the Endangered Species Act Administrative Record for fall chinook salmon, National Marine Fisheries Service, Portland, Oregon.

Bugert, R., P. Seidel, P. LaRiviere, D. Marbach, S. Martin, and L. Ross. 1989. Lyons Ferry Hatchery Evaluation Program, 1988 annual report, Cooperative Agreement 14-16-001-88519 to Lower Snake River Compensation Plan, U.S. Fish and Wildlife Service, Boise, Idaho.

Bugert, R., P. LaRiviere, D. Marbach, S. Martin, L. Ross, and D. Geist. 1990. Lyons Ferry Hatchery Evaluation Program, 1989 annual report, Cooperative Agreement 14-16-0001-89525 to Lower Snake River Compensation Plan, U.S. Fish and Wildlife Service, Boise, Idaho.

Bugert, R., C. Busack, G. Mendel, K. Petersen, D. Marbach, L. Ross, and J. Dedloff. 1991. Lyons Ferry Hatchery Evaluation Program, 1990 annual report, Cooperative Agreement 14-16-001-90525 to Lower Snake River Compensation Plan, U.S. Fish and Wildlife Service, Boise, Idaho.

COE (U.S. Army Corp of Engineers). 1990. Navigation charts of the Snake River, Oregon, Washington, and Idaho. Lewiston, Idaho to Johnson Bar. U.S. Army Corp of Engineers, Walla Walla District, Walla Walla, Washington.

Connor, W.P., A.P. Garcia, H.L. Burge, and R.H. Taylor. 1993. Fall chinook salmon spawning in free-flowing reaches of the Snake River. Pages 1-29 in D.W. Rondorf and W.H. Miller, editors. Identification of the spawning, rearing, and migratory requirements of fall chinook salmon in the Columbia River basin. 1991 Annual Progress Report (contract DE-AI79-91BP21708) to Bonneville Power Administration, Portland, Oregon.

Groves, P.A. 1993. Habitat available for, and used by, fall chinook salmon within the Hells Canyon Reach of the snake River. Annual Progress Report 1992. Environmental Affairs Department, Idaho Power Company, Boise, Idaho. 
Irving, J.S. and T.C. Bjornn. 1981. Status of Snake River fall chinook salmon in relation to the Endangered Species Act. Prepared for the U.S. Fish and Wildlife Service, Portland, Oregon.

Kenney, D. 1992. Memorandum on fish eggs and fry recovered in dredged material below Lower Monumental Project. U.S. Army Corps of Engineers, Walla Walla District, Walla Walla, Washington.

Mendel, G., K. Petersen, R. Bugert, D. Milks, L. Ross, J. Dedloff, and L. LaVoy. 1992. Lower Snake River Compensation Plan Lyons Ferry fall chinook salmon hatchery program. 1991 Evaluation Report. Cooperative Agreement 1416-0001-91534, Washington Department of Fisheries report to the U. S. Fish and Wildlife Service, Lower Snake River Compensation Plan Office, Boise, Idaho.

Mendel, G., D. Milks, R. Bugert. 1993. Upstream passage and spawning of fall chinook salmon in the Snake River, 1992. 1992 Draft Progress Report. Cooperative Agreement 92-46, Washington Department of Fisheries report to the Bonneville Power Administration, Portland, Oregon.

NMFS (National Marine Fisheries Service). 1992. Threatened status for Snake River spring/summer chinook salmon, threatened status for snake River fall chinook salmon. Final rule, April 22, 1992. Federal Register, Vol. 57, No. 78 .

Seidel, P., R. Bugert, P. LaRiviere, D. Marbach, S. Martin, and L. Ross. 1988. Lyons Ferry Evaluation Program, 1987 annual report Cooperative Agreement 14-16-0001-87512 to Lower Snake River Compensation Plan, U.S. Fish and Wildlife Service, Boise, Idaho.

Witty, K.L. 1988. Annual Fish Report. Wallowa Fish District. Oregon Department of Fish and Wildlife, Enterprise, Oregon. 


\section{CHAPTER TWO}

Snake River Flows and Temperature During the 1992 snake River
Fall Chinook Salmon Brood Year

\section{by}

W.P. Connor

U.S. Fish and Wildlife Service Idaho Fishery Resource Office Ahsahka, Idaho 83520, USA

and

A.H. Connor and R.H. Taylor U.S. Forest Service

Clearwater National Forest Orofino, Idaho 83544, USA 


\section{Introduction}

Knowledge of the effects of Snake River flows and water temperatures on fall chinook salmon Oncorhynchus tshawytscha spawning habitat in the free-flowing snake River is urgently needed. When the National Marine Fisheries Service was petitioned to list Snake River fall chinook salmon under the Endangered Species Act (ESA; National Marine Fisheries Service 1992), our understanding of how the operation of Brownlee, Oxbow, and Hells Canyon dams

(Hells Canyon Complex) affect the spawning success of Snake River fall chinook consisted of an 18 year-old flow versus habitat study (Bayha 1974). With the ESA petition came renewed interest in obtaining information on Snake River fall chinook salmon spawning since our present understanding was not sufficient for recovery planning.

Our 1992 work was a continuation of research that began in 1991 to establish the relation between Hells Canyon Complex discharge and the availability of Snake River fall chinook salmon habitat at selected index sites (Connor et al. 1993). Study objectives for 1992 were: (1) describe snake River discharge and water temperatures during the fall chinook salmon immigration, spawning, and egg incubation periods of the 1992 brood year and (2) model the effects of changes in river flow on fall chinook salmon spawning habitat at the RK 261 study site.

\section{Study Area}

The study area included the Snake River from Hells Canyon Dam to its mouth (Figure 1). We describe specific locations within the area in terms of river kilometers (RK) based on the navigation charts of the Snake River produced by the United States Army Corps of Engineers (COE). Our main focus in 1992 was on the free-flowing reach of the Snake River between Hells Canyon Dam (RK 398) and the head of Lower Granite Reservoir near Asotin, Washington (RK 235).

\section{Methods}

\section{Data Collection}

Discharge and water temperature.-Snake River provisional discharge data collected near Anatone Washington (Anatone gage; RK 270), were furnished by the United States Geological Survey (USGS) for the 1991-1993 time period (Appendix 1). The USGS also provided Snake River provisional discharge data for Hells Canyon Dam, and the Imnaha, Salmon, and Grande Ronde rivers for 1991-1993 


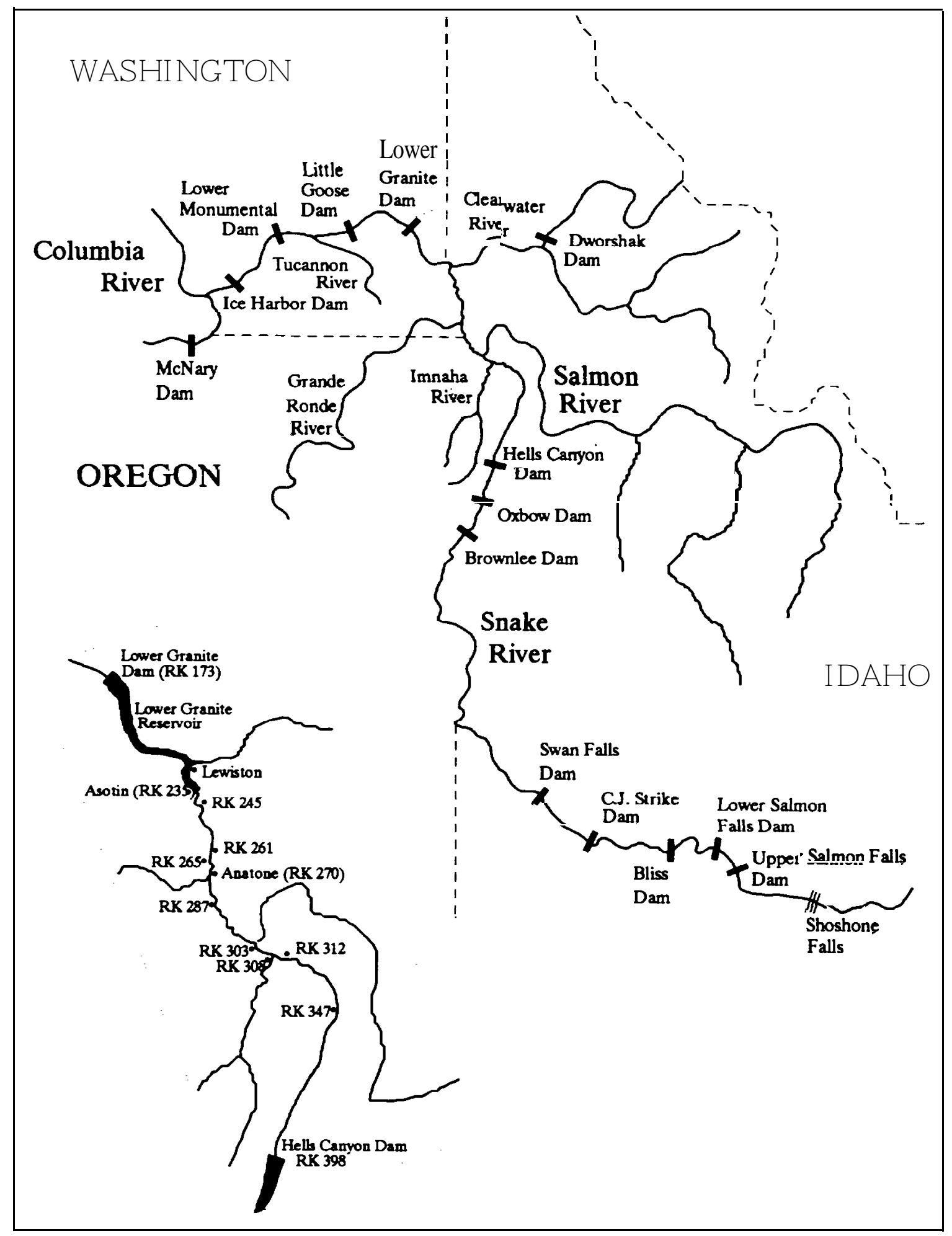

Figure 1.-Map of the Snake River drainage with inset showing the 1992 fall chinook salmon spawning study site at RK 261, Anatone Gage at RK 270, Hells Canyon Dam at RK 398, and thermograph locations (refer to Table 1 for river kilometers). 
(Appendix 2). Water discharge data are reported in this chapter in thousands of cubic feet per second (KCFS) based on USGS

standards.

Snake River water temperature data were collected from 19911993 by thermograph at RK 347 and RK 265 near Pittsburg Landing and Billy Creek (Appendix 3).

Discharge and spawning habitat.-We used the Instream Flow Incremental Methodology (IFIM Bovee 1982) to collect habitat data at the fall chinook salmon spawning sites including the site located at RK 261. We collected channel elevations, water surface elevations, water velocities, and substrate codes at cross sections placed within the study site (Appendix 4). Cross sections were placed through the middle and around known spawning areas. The downstream cross section at each site was always placed at a point of hydraulic control. Because of frequent boat traffic we did not stretch a cable across the channel for positioning our gaging boat. Instead we affixed a prism to the bow of our gaging boat and surveyed the location of each flow measurement as we progressed across the channel. We also collected channel elevations and substrate codes (Brusven 1977; refer to Garcia et al. in this report for particle dimension codes) between the IFIM cross sections to allow detailed site mapping. Onshore and shallow-water channel elevations and substrate codes were measured by sighting a prism on a rod at the point of data collection. Offshore channel elevations were collected using a boat equipped with sounding gear and a prism for surveying measurement locations.

\section{Data Analysis}

Snake River discharge and water temperatures.-We used our 19 91- 1993 data (Connor et al. 1993; Connor et al. in this report; Garcia et al. in this report) to define the timing of each fall chinook salmon life stage in the 1992 and 1993 brood years (August immigration through June fry emergence) for relation to snake River discharge. A comparison of Snake River flows was made using the 1991-1993 data.

We analyzed Hells Canyon Complex, Imnaha, Salmon, and Grande Ronde river discharge data from the 1992 fall chinook salmon brood year to demonstrate the potential effect each water source had on main stem snake River flow volume and fluctuation at Anatone gage. Part of this analysis was based on the percentage of discharge contributed by each of the above water sources. We also examined daily changes in the discharge at the Anatone gage relative to changes in discharge of each of the above water sources. 
As in our discharge analysis, we used the life stage timing of the 1991 and 1992 fall chinook salmon brood years as part of the water temperature analysis. Water temperature data from 1991-1993 collected by thermograph at RK 347 and RK 265 were compared for each fall chinook salmon life stage.

Spawning habitat modelling.-We calculated discharge, distances between cross sections, water surface elevations, site gradient, distances between vertical measurements, the mean column velocity, and the elevation of the channel bottom at each vertical. Because the measurements along a cross section were not taken from a fixed cable, there was some lateral scatter in survey points. A trigonometric conversion was used to bring the points into line and calculate a corrected location for each vertical measurement. We converted the above data into an input file for hydraulic modelling.

We selected IFG4 (Milhous et al. 1989) as our hydraulic model. The purpose of our 1992 hydraulic analysis was to simulate the depths and velocities that occurred during fall chinook spawning in 1991 and 1992 at cross section four of the RK 261 spawning study site. Cross section four was located directly through the fall chinook salmon redds surveyed in both 1991 and 1992 (Connor et al. 1993, Garcia et al. in this report). Calibration, which consists of making adjustments to the IFG4 data deck, was required prior to predicting depth and velocity.

There are two stages in the calibration of IFG4. First, a stage-discharge rating curve was fit to each cross section. IFG4 achieves this by running a log-log regression analysis on the measured stage and discharge. The resulting rating curve is in the form:

$$
\begin{aligned}
& Q=a \quad(W S E-S Z F)^{\text {D }} \\
& \text { Where: } \\
& \text { Q is discharge; } \\
& \text { a is a regression constant; } \\
& \text { WSE is water surface elevation; } \\
& \text { SZF is stage of zero flow; and } \\
& \text { b is a regression constant. }
\end{aligned}
$$

The SZF is the water surface elevation at a cross-section when the flow is decreased to zero. The SZF is either the elevation of the lowest point on the cross-section or the pool water surface when a downstream hydraulic control is present. The stage of zero flow acts as a calibration variable.

Once a good fit was achieved in the stage-discharge calibration, the second step in IFG4 calibration termed "velocity calibration" was initiated. Velocity data collected during each velocity calibration flow were run through IFG4 in separate data 
decks. When only one velocity set is supplied in a data deck, IFG4 uses a variation of Manning's equation to calculate Manning's $n$ for each vertical measurement. Manning's $n$ represents channel roughness but acts as a calibration variable in IFG4. Manning's equation, when used with a single velocity

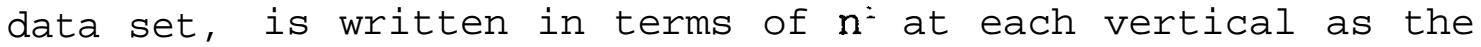
unknown:

Where: $\begin{aligned} & \mathrm{n}_{:}=\left(1.49 \star \mathrm{S}_{\mathrm{e}}{ }^{1 / 2} \mathrm{~d}_{\mathrm{i}}{ }^{2 / 3}\right) / \mathrm{v}_{\mathrm{i}} \\ & \mathrm{n}_{\mathrm{i}} \text { is the Manning's } \mathrm{n} \text { value at vertical } i \\ & \mathrm{~S}_{\mathrm{e}} \text { is the energy slope for the cross-section; } \\ & \mathrm{d}_{:} \text {is the depth at vertical i; and } \\ & \mathrm{v}_{:} \text {is the velocity at vertical i. }\end{aligned}$

The $n$ : values calculated at the calibration flow are then used in Manning's equation written in terms $v_{i}$ of to predict the velocity at each vertical measurement at the simulated discharge. The velocity predicted at each vertical is then used to calculate the discharge in each cell across the cross section and then summed for the entire cross section, resulting in a predicted discharge.

A mass balancing procedure is used by IFG4 to ensure that the discharge predicted by a velocity set is equal to the simulated discharge. The simulated discharge is divided by the discharge predicted by the velocity set to yield a velocity adjustment factor (VAF). The velocity at each vertical is then multiplied by the VAF to yield a final velocity profile for the simulated discharge.

Gaged flows that were not used as the calibration flow were then simulated and the resulting predicted velocity profiles were compared to the gaged velocity profiles. Velocity calibration consists of modifying the $n$ values, when there is a physical reason to do so, to achieve a reasonable velocity profile. Extreme flows (minimum of $5.0 \mathrm{KCFS}$ and maximum of $99.0 \mathrm{KCFS}$ ) were also simulated in order to find any inappropriate velocities and $n$ values.

After we completed the above two steps of data deck calibration, we proceeded with simulation of the water depths and velocities of the fall chinook salmon spawning area at RK 261 using the hydrograph of the 1992 fall chinook salmon brood year. Three distinct points along cross-section four were chosen to represent the center of the spawning site, the shallow edge of the spawning site and the deep edge of the spawning site. These points coincide closely with the actual locations and elevations of redds observed during the 1992 spawning season. Depth and velocity over each of these points was extracted from the model output for the range of simulated flows. 
Discharge

Snake River average daily discharge differed substantially between the 1991 and 1992 brood years (Figure 2). During the 1992 brood year immigration, adult fall chinook salmon experienced discharges (mean $12.2 \mathrm{KCFS}$; range 9.2-15.1 $\mathrm{KCFS}$ ) that were 77\% of immigration flows in 1991 (15.8 KCFS; range 11.0-23.3 KCFS). During fall chinook salmon spawning in the 1992 brood year, discharge (mean $13.4 \mathrm{KCFS}$; range $11.8-14.3 \mathrm{KCFS}$ ) was about 85\% of the 1991 mean (15.7 KCFS; range 13.9-19.5 KCFS). During fall chinook salmon egg incubation of the 1992 brood year, discharge (mean 35.5 KCFS; range 11.8-118.0 KCFS) was about $171 \%$ of the 1991 mean (20.7 KCFS; range $13.9-47.2 \mathrm{KCFS})$. During fall chinook salmon fry emergence of the 1992 brood year, discharge (mean 68.1 KCFS; range 25.9-118.0 KCFS) was about 252\% of the 1991 mean (27.0 KCFS; range $18.4-47.2$ KCFS).

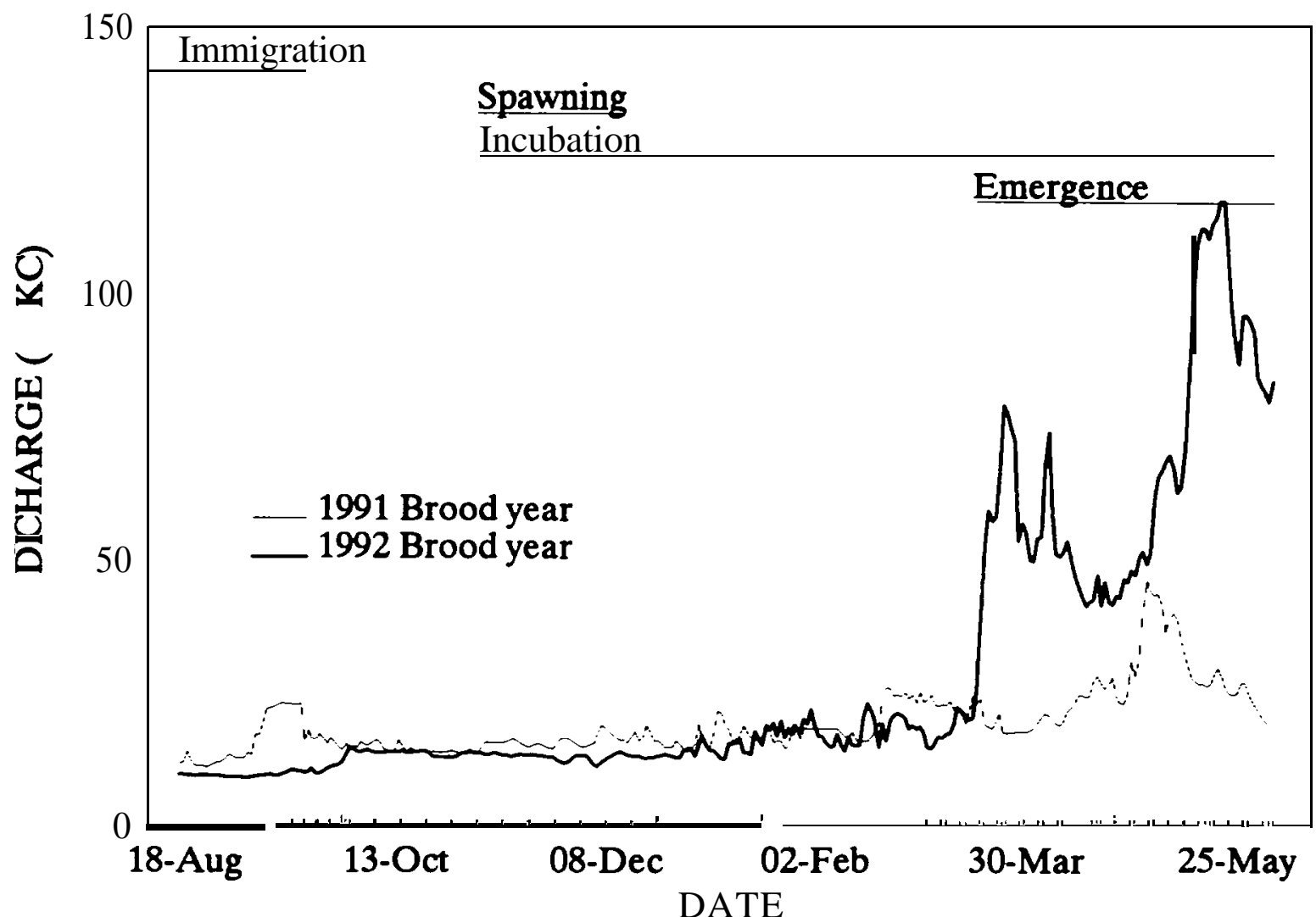

Figure 2.-Snake River average daily discharge for the 1991 and 1992 fall chiook salmon brood years. Provisional discharge data were provided by the Umted States Geological Survey for Anatone gage, Washington. 
Hells Canyon Complex water releases made up most of the Snake River's discharge measured at Anatone gage during adult fall chinook salmon immigration (69\%), spawning (68\%), early egg incubation (71\%) and late egg incubation (50\%) for the 1992 brood year (Table 1). The Salmon River contributed from 21-31\% of the discharge gaged at Anatone over the 1992 fall chinook salmon brood year. The Grande Ronde's contribution of flow for the 1992 fall chinook salmon brood year ranged from S-12\%. Imnaha River contributed comparatively little discharge (range 1-2\%) to the main stem Snake River at the Anatone gage for the periods described above.

Table 1--Discharge contribution by Hells Canyon Dam, Imnaha River, Salmon River, and the Grande Ronde River to the main stem Snake River at the Anatone gage of Washington during the 1992 fall chinook salmon brood year. Total flow does not always sum to 100 percent because the gage stations are not synchronized and the data were provisional.

\begin{tabular}{|c|c|c|c|c|c|c|}
\hline \multirow[t]{2}{*}{ Life stage } & \multirow[t]{2}{*}{ Date } & \multicolumn{2}{|c|}{ Percent of } & Snake Ri v & $\begin{array}{l}\text { r di scharge } \\
\text { source }\end{array}$ & contributed \\
\hline & & & $\begin{array}{l}\text { Is Canyon } \\
\text { Dam }\end{array}$ & $\begin{array}{l}\text { n Imnaha } \\
\text { Ri ver }\end{array}$ & $\begin{array}{l}\text { Salmon } \\
\text { Ri ver }\end{array}$ & $\begin{array}{c}\text { Grande Ronde } \\
\text { Ri ver }\end{array}$ \\
\hline $\begin{array}{l}\text { I migrati on } \\
\text { Spawning } \\
\text { Earl y incubati on } \\
\text { Late incubat ion }\end{array}$ & $\begin{array}{l}18 \text { Aug - } 23 \text { Nbv } 9 \\
5 \text { Nbv - } 12 \text { Dec } 92 \\
5 \text { Nbv- } 92-\text { Feb } 17 \\
18 \text { Feb }-4 \text { Jun } 93\end{array}$ & 93 & $\begin{array}{l}69 \\
68 \\
71 \\
50\end{array}$ & $\begin{array}{l}1 \\
1 \\
1 \\
2\end{array}$ & $\begin{array}{l}26 \\
25 \\
21 \\
31\end{array}$ & $\begin{array}{r}5 \\
6 \\
6 \\
12\end{array}$ \\
\hline
\end{tabular}

Since Hells Canyon Complex discharge dominated the snake River's flow volume at Anatone gage, it also influenced the pattern of daily flow fluctuation throughout the 1992 fall chinook salmon brood year (Figure 3). The largest fluctuation at Anatone gage during 1992 immigration was a $3.3 \mathrm{KCFS}$ increase over the period of 29 September (11.8 KCFS) to 2 October (15.1 KCFS). This 3.3 KCFS increase was attributable to a 3.8 KCFS rise in Hells Canyon Complex flows during the same period of time. Subsequently, there was little flow fluctuation during immigration until 24 October when Hells Canyon Complex flows were dropped by $1.2 \mathrm{KCFS}(10.3$ to $9.1 \mathrm{KCFS})$. This reduction in Hells Canyon Complex flows on 24 October was followed by a 1.2 KCFS drop in Snake River flow at Anatone gage by 25 October.

Snake River discharge measured at Anatone gage during 1992 fall chinook salmon spawning averaged 13.4+0.6 KCFS (range 11.814.3 KCFS; Figure 3). The largest discharge fluctuation for a 24-h period of spawning was a 1.0 KCFS drop measured at Anatone on 5 December. This 1.0 KCFS decrease at Anatone gage was 


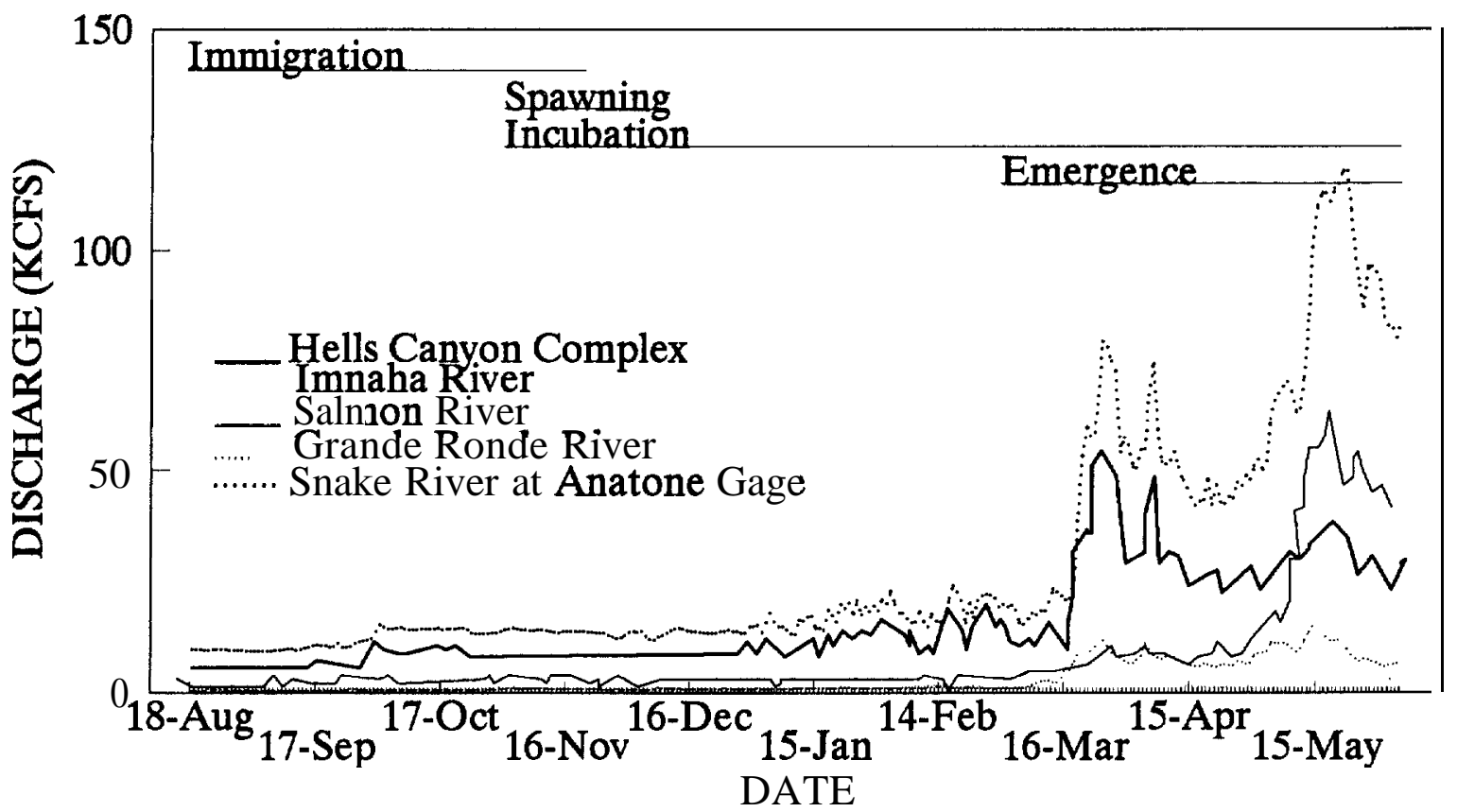

Figure 3.-Average daily discharge at Hells Canyon Dam, Imnaha River, Salmon River, Grande Ronde River, and the main stem Snake River at Anatone Gage, Washington during the 1992 fall chinook salmon brood year. Provisional data were provided by the United States Geological Survey.

attributed to decreases in Salmon River flows of $1.5 \mathrm{KCFS}$ and 0.8 KCFS on 27 November and 5 December, respectively. The highest flow (14.3 KCFS) during fall chinook salmon spawning occurred on 12 December, 1992. The last date new fall chinook salmon redds were counted in 1992 was also on 12 December (Garcia et al. in this report). Snake River discharge at Anatone gage was below 14.3 KCFS 37\% (21 d) of the time during early fall chinook salmon egg incubation (decrease ranged from 0.1-1.2 KCFS). Most of the flows which were below $14.3 \mathrm{KCFS}$ were caused by the low flows in the Salmon River. On 10 January, 1993 the Salmon River dropped 1.19 KCFS which accounts for all but. 01 KCFS of the maximum 24-h decrease of 1.2 KCFS during the early part of fall chinook salmon egg incubation.

The erratic hydrograph that began about 3 January was indicative of hydroelectric generation by Hells Canyon Complex, often termed power peaking (Figure 3). Hells Canyon Complex discharge fell below its highest flow release (9.4 KCFS) that occurred during fall chinook salmon spawning for 2 d during the egg incubation period. The maximum difference between the high spawning flow of and the low flow during incubation was $0.6 \mathrm{KCFS}$.

A marked increase in Snake River discharge at Anatone gage began on 19 March, 1993 with the start of spring runoff (Figure 3). The spring runoff pattern through fall chinook salmon fry 
emergence was bimodal. The early peak occurred on 25 March (79.7 KCFS) and was dominated by Hells Canyon Complex flows of 48.654.8 KCFS. The late peak occurred on 21 May and was comprised of mostly Salmon River water (60.2-64.2 KCFS).

\section{Water Temperature}

Snake River average daily water temperatures at RK 347 were similar between the 1991 and 1992 brood years until early into the fall chinook egg incubation period (Figure 4). During the 1992 brood year immigration, adult fall chinook salmon experienced water temperatures (mean $17.1^{\circ} \mathrm{C}$; range $10.9-21.1^{\circ} \mathrm{C}$ ) that were comparable to water temperatures in 1991 (mean $17.6^{\circ} \mathrm{C}$; range $\left.11.1-21.3^{\circ} \mathrm{C}\right)$. During fall chinook salmon spawning in the 1992 brood year, water temperature (mean $10.3^{\circ} \mathrm{C}$; range 6.8$\left.13.9^{\circ} \mathrm{C}\right)$ was within $1.0^{\circ} \mathrm{C}$ of the 1991 mean $\left(10.9^{\circ} \mathrm{C}\right.$; range $7.5-$ 14. $\left.9^{\circ} \mathrm{C}\right)$. During the early part of fall chinook salmon egg incubation of the 1992 brood year, water temperature (mean 6. $1^{\circ} \mathrm{C}$; range $\left.1.5-13.9^{\circ} \mathrm{C}\right)$ was cooler than the 1991 mean $\left(7.7^{\circ} \mathrm{C}\right.$; range $\left.3.9-14.9^{\circ} \mathrm{C}\right)$. The cooler pattern in water temperatures between 1992 and 1991 brood years continued through the later part of egg incubation (1992 mean $7.2^{\circ} \mathrm{C}$; range $1.5-16.6^{\circ} \mathrm{C}$ and 1991 mean $8.1^{\circ} \mathrm{C}$; range $\left.3.6-13.5^{\circ} \mathrm{C}\right)$. During fall chinook salmon fry emergence of the 1992 brood year, water temperature (mean $10.8^{\circ} \mathrm{C}$; range $4.1-$ $\left.16.6^{\circ} \mathrm{C}\right)$ was cooler than the 1991 mean $\left(12.5^{\circ} \mathrm{C}\right.$; range $\left.9.5-15.4^{\circ} \mathrm{C}\right)$.

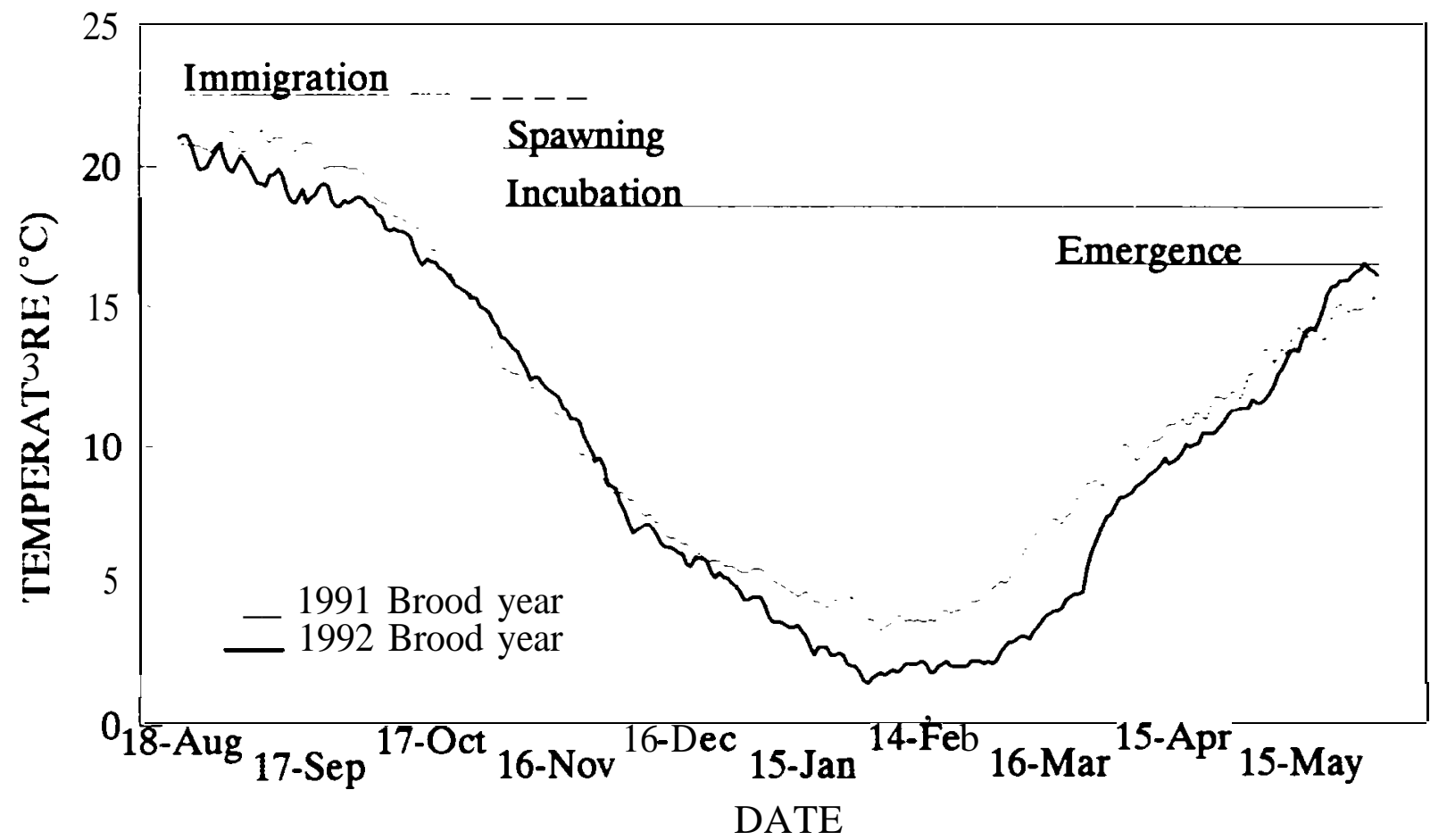

Figure 4.-Average daily Snake River water temperatures at RK 347 for the 1991 and 1992 fall chinook salmon brood years. 
emergence was bimodal. The early peak occurred on 25 March (79.7 KCPS) and was dominated by Hells Canyon Complex flows of 48.654.8 KCFS. The late peak occurred on 21 May and was comprised of mostly Salmon River water (60.2-64.2 KCFS).

\section{Water Temperature}

Snake River average daily water temperatures at $\mathbf{R K} 347$ were similar between the 1991 and 1992 brood years until early into the fall chinook egg incubation period (Figure 4). During the 1992 brood year immigration, adult fall chinook salmon experienced water temperatures (mean $17.1^{\circ} \mathrm{C}$; range $10.9-21.1^{\circ} \mathrm{C}$ ) that were comparable to water temperatures in 1991 (mean $17.6^{\circ} \mathrm{C}$; range $11.1-21.3^{\circ} \mathrm{C}$ ). During fall chinook salmon spawning in the 1992 brood year, water temperature (mean $10.3^{\circ} \mathrm{C}$; range 6.8$13.9^{\circ} \mathrm{C}$ ) was within $1.0^{\circ} \mathrm{C}$ of the 1991 mean $\left(10.9^{\circ} \mathrm{C}\right.$; range $7.5-$ $14.9^{\circ} \mathrm{C}$ ). During the early part of fall chinook salmon egg incubation of the 1992 brood year, water temperature (mean 6.1 ${ }^{\circ} \mathrm{C}$; range $1.5-13.9^{\circ} \mathrm{C}$ ) was cooler than the 1991 mean $\left(7.7^{\circ} \mathrm{C}\right.$; range 3.9-14. $9^{\circ} \mathrm{C}$ ). The cooler pattern in water temperatures between 1992 and 1991 brood years-continued through the later part of egg incubation $\left(1992\right.$ mean $7.2^{\circ} \mathrm{C}$; range $1.5-16.6^{\circ} \mathrm{C}$ and 1991 mean 8.1\% range $3 \cdot 6-13 \cdot 5^{\circ} \mathrm{C}$ ) . During fall chinook salmon fry emergence of the 1992 brood year, water temperature (mean $10.8^{\circ} \mathrm{C}$; range 4.1$16.6^{\circ} \mathrm{C}$ ) was cooler than the 1991 mean $\left(12.5^{\circ} \mathrm{C}\right.$; range $\left.9.5-15.4^{\circ} \mathrm{C}\right)$.

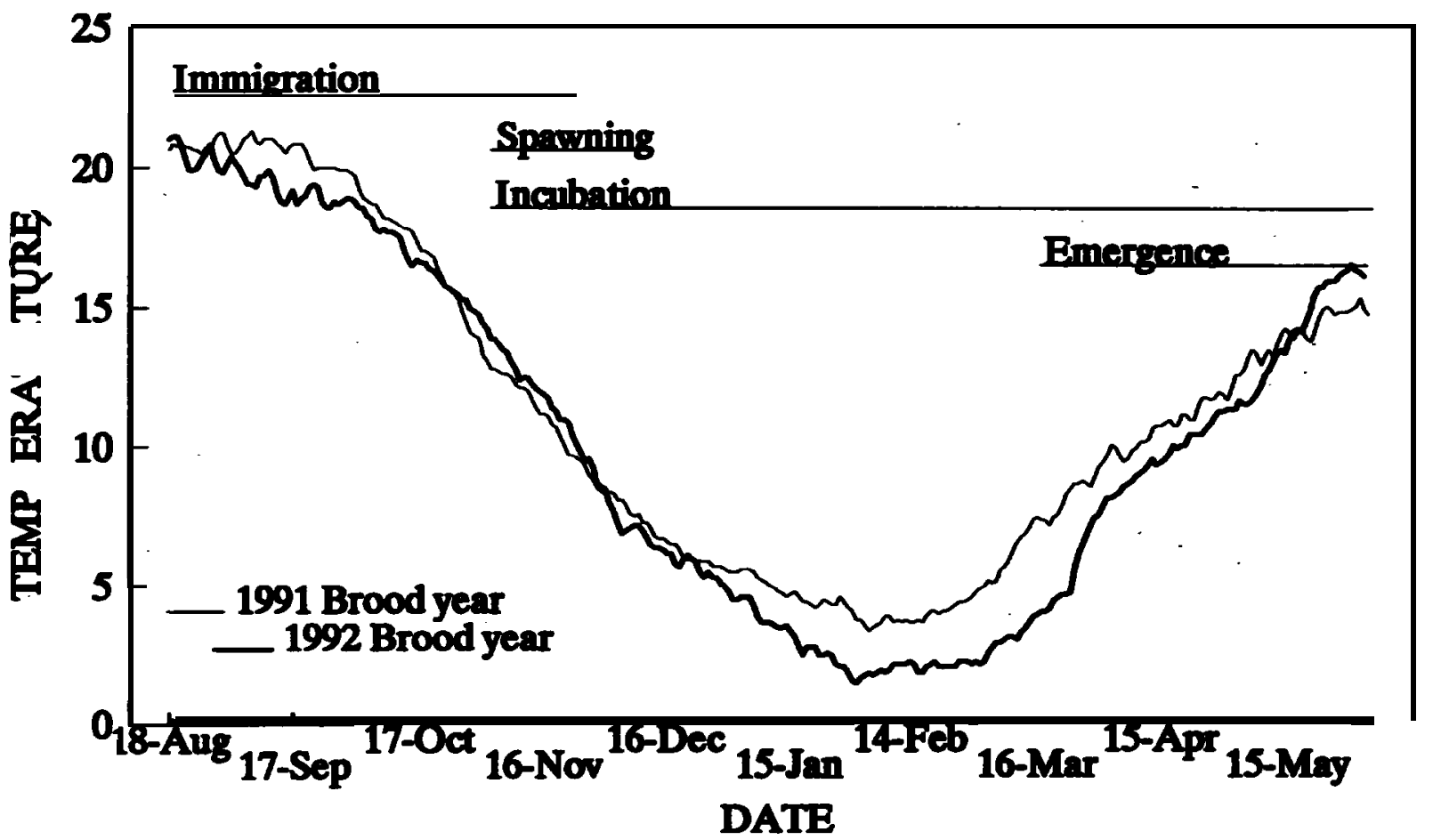

Figure 4.-Average daily Snake River water tèmperatures at RK 347 for the 1991 and 1992 fall chinook salmon brood years. 
The comparison of Snake River mean daily water temperature at RK 265 between the 1991 and 1992 fall chinook salmon brood years (Figure 5) is quite similar to that described above at $R R$ 347. During the 1992 brood year immigration, fall chinook salmon were subjected to temperatures (mean $15.9^{\circ} \mathrm{C}$; range $8.5-22.5^{\circ} \mathrm{C}$ ) that were'cooler than in. 1991 (mean $16.4^{\circ} \mathrm{C}$; range $8.9-21.8^{\circ} \mathrm{C}$ ). During fall chinook salmon spawning in the 1992 brood year, water temperature (mean $8.1^{\circ} \mathrm{C}$; range $4.9-11.7^{\circ} \mathrm{C}$ ) was cooler than the 1991 mean $\left(8.7^{\circ} \mathrm{C}\right.$; range $\left.6.0-12.4^{\circ} \mathrm{C}\right)$. During the early part of fall chinook salmon egg incubation of the 1992 broodyear, water temperature (mean $4.9^{\circ} \mathrm{C}$; range $1.6-11.7^{\circ} \mathrm{C}$ ) was cooler than the 1991 mean $\left(6.3^{\circ} \mathrm{C}\right.$; range $\left.3.3-12.4^{\circ} \mathrm{C}\right)$. During the later part of fall chinook salmon egg incubation of the 1992 brood year, water temperature (mean $7.2^{\circ} \mathrm{C}$; range $1.6-14.0^{\circ} \mathrm{C}$ ) averaged $1.6^{\circ} \mathrm{C}$ cooler than water temperature of $1991\left(8.8^{\circ} \mathrm{C}\right.$; range $\left.3.1-14.0^{\circ} \mathrm{C}\right)$. During fall chinook salmon fry emergence of the 1992 brood year, water temperature (mean $10.4^{\circ} \mathrm{C}$; range $5.6-14.0^{\circ} \mathrm{C}$ ) was cooler than the 1991 brood year mean $\left(13.0^{\circ} \mathrm{C}\right.$; range $\left.9.5-17.5^{\circ} \mathrm{C}\right)$.

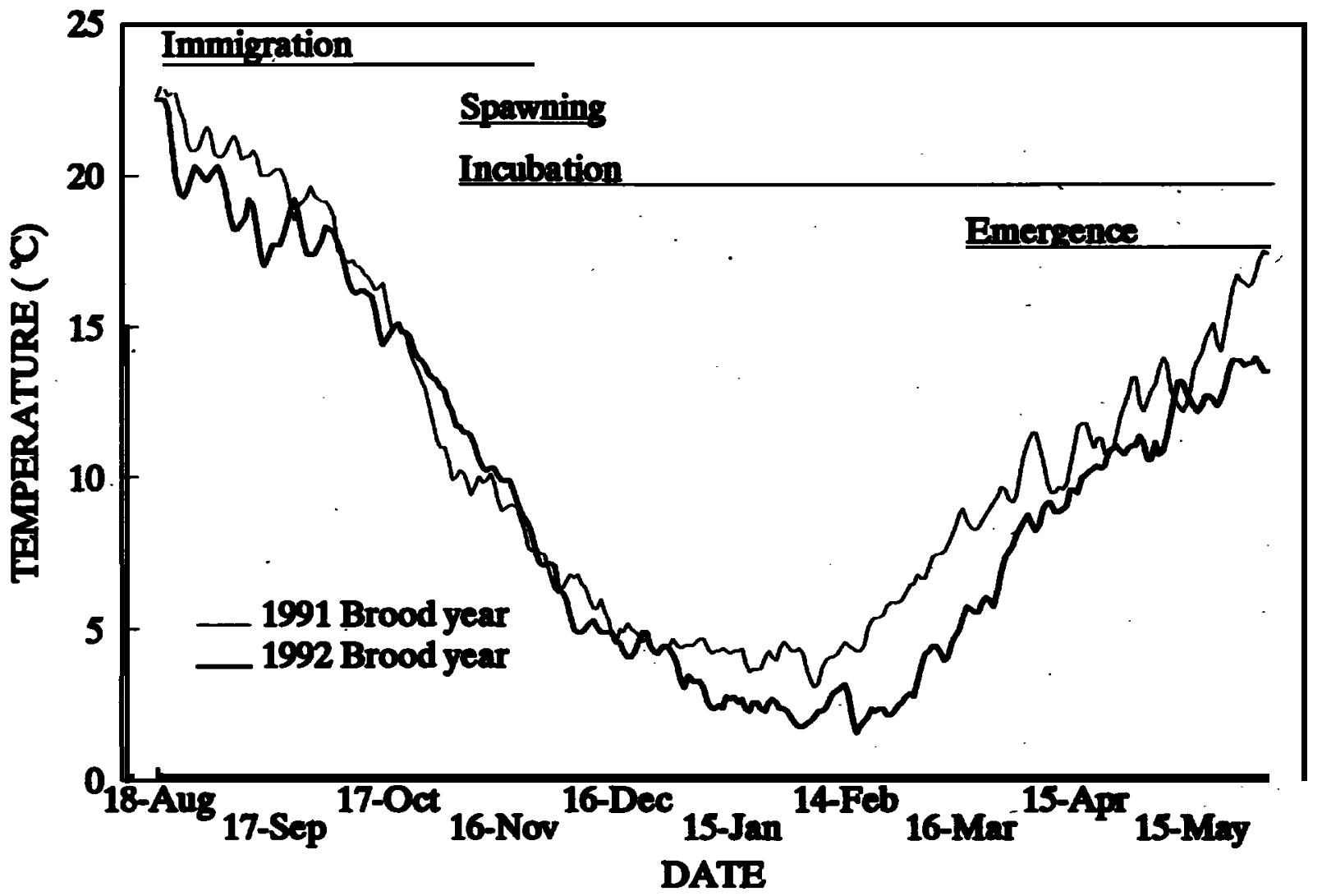

Figure 5.-Average daily Snake River water temperatures at RK 265 for the 1991 and 1992 fall chinook salmon brood years. 
The Snake River was generally warmer upriver (RK 347) 'than downriver ( $R R$ 265) through fall chinook salmon spawning and early egg incubation of the 1992 brood year, until 18 January when the temperatures became similar (Figure 6). During fall chinook salmon immigration of the 1992 brood year, mean daily water temperature varied by river kilometer and was warmer upriver (RK 347 mean $17.1{ }^{\circ} \mathrm{C}$; $R R 265$ mean $15.9^{\circ} \mathrm{C}$ ). The Snake River remained warmer at $R R 347$ than at $R R 265$ through fall chinook salmon spawning (means $10.3^{\circ} \mathrm{C}$ and $8.1^{\circ} \mathrm{C}$ ). Upriver water temperature continued to be warmer than downriver water temperature through early incubation ( $R R 398$ mean $6.1^{\circ} \mathrm{C}$; $R R 265$ mean $4: 9^{\circ} \mathrm{C}$ ) until 18 January, 1993 when up and downstream Snake River water temperatures became similar ( $R R 398$ mean $7.2^{\circ} \mathrm{C}$; $R R 265$ mean $\left.7.2^{\circ} \mathrm{C}\right)$. The Snake River did not go below freezing at either RR 347 or RR 265 during the 19-92 fall chinook salmon brood year (minimums $1.5^{\circ} \mathrm{C}$ and $1.6^{\circ} \mathrm{C}$, respectively). Snake River water temperatures were comparable up and downstream for the first $52 \mathrm{~d}$ of fall chinook salmon fry emergence (means $R R 3479.1^{\circ} \mathrm{C}$ and $R R$ $2659.3^{\circ} \mathrm{C}$ ). The upper river became warmer ( $R R 398$ mean $15.3^{\circ} \mathrm{C}$; $\mathrm{RK} 265$ mean $9.3^{\circ} \mathrm{C}$ ) over the last $21 \mathrm{~d}$ of emergence starting on 14 May.

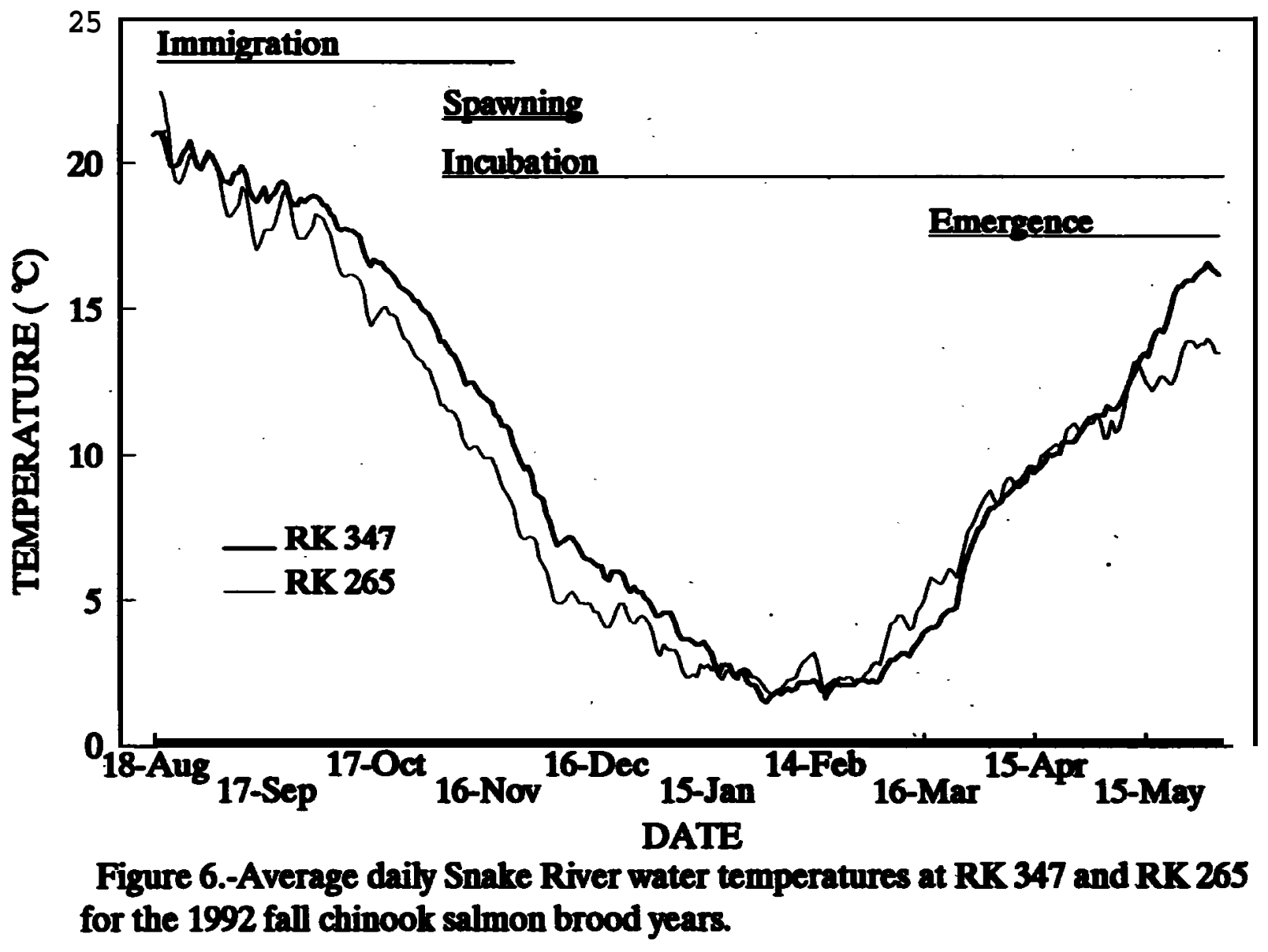




\section{Spawning Habitat Modelling}

Water depths simulated using IFG4 at cross section four of the RK 261 spawning study site (Figure 7) varied considerably over the range of discharges during the 1992 fall chinook salmon brood year (Figure 8). Simulated water depth at the point representing the center of the spawning site ranged from 0.7-0.9 $\mathrm{m}$ over the range of discharges occurring during spawning in 1992. Simulated water depth at the point representing shallow redds ranged from $0.3-0.5 \mathrm{~m}$ during the same time period, while simulated water depth at the point representing deep redds ranged from $1.0-1.2 \mathrm{~m}$.

The model predicted that the point representing the shallow redds would be dewatered at discharges of $7.4 \mathrm{KCFS}$ and less. The center redds would be dewatered at discharges of 5.4 KCFS and less. Deep water redds would remain submerged at $5.0 \mathrm{KCFS}$, the lowest discharge modelled. No redds would be dewatered over the range of flows recorded during the 1992 fall chinook salmon brood year.

Mean water column velocities simulated using IFG4 at the spawning site at RK $26 i$ also varied considerably from the shallow redds to the deep redds (Figure 9). Simulated mean column velocity at the point representing the center of the spawning site ranged from $0.8-1.0 \mathrm{~m} / \mathrm{s}$ over the range of discharges occurring during spawning in 1992. Simulated mean column velocity at the shallow redds ranged from $0.3-0.5 \mathrm{~m} / \mathrm{s}$ during the same time period while mean column velocity at the deeper redds ranged from $0.9-1.1 \mathrm{~m} / \mathrm{s}$.

The mean discharge during the fall chinook salmon spawning period was $2.3 \mathrm{KCFS}$ less in 1992 than in 1991. Thus, the water surface elevation and velocities across the cross section were less in 1992 than in 1991 (Figure 10). The simulated water surface elevation at the mean spawning discharge was $0.2 \mathrm{~m}$ less in $1992(291.2 \mathrm{~m})$ than in $1991(291.4 \mathrm{~m})$. The simulated mean channel velocity at the mean spawning discharge was $0.1 \mathrm{~m} / \mathrm{s}$ less in $1992(1.1 \mathrm{~m} / \mathrm{s})$ than in $1991(1.2 \mathrm{~m} / \mathrm{s})$. The mean column velocity over the center of the redds at the mean spawning discharge was $0.2 \mathrm{~m} / \mathrm{s}$ less in $1992(0.9 \mathrm{~m} / \mathrm{s})$ than in 1991 (1.1 $\mathrm{m} / \mathrm{s})$. 


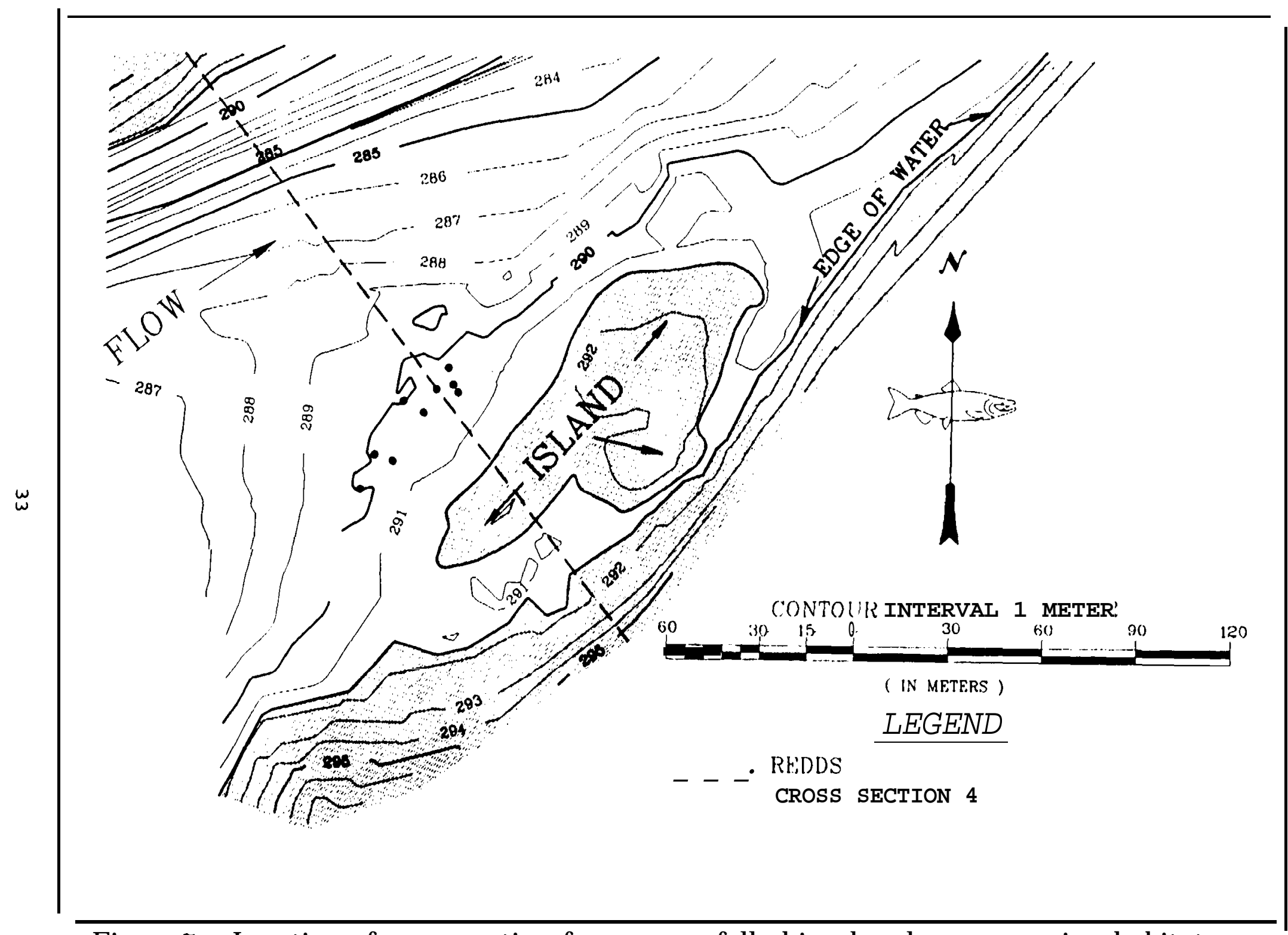

Figure 7.- Location of cross section four across fall chinook salmon spawning habitat at RK 261. 


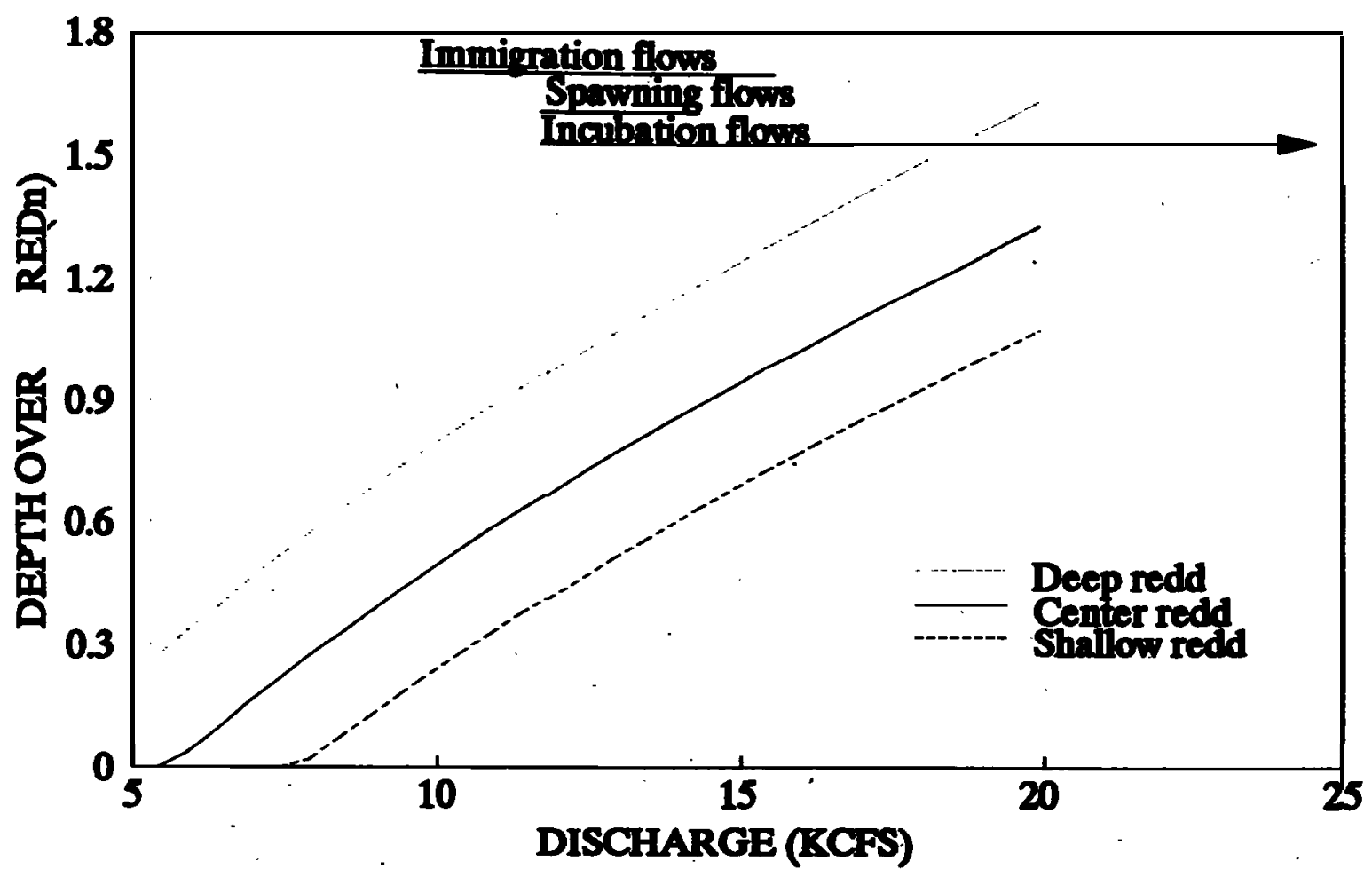

Figure 8.-Water depths at points representing the center of the speryning site at R 261, the sin 1 or ef of of te spuwing site and the deep ed ge of the spawning site, as modeled using ifG4.

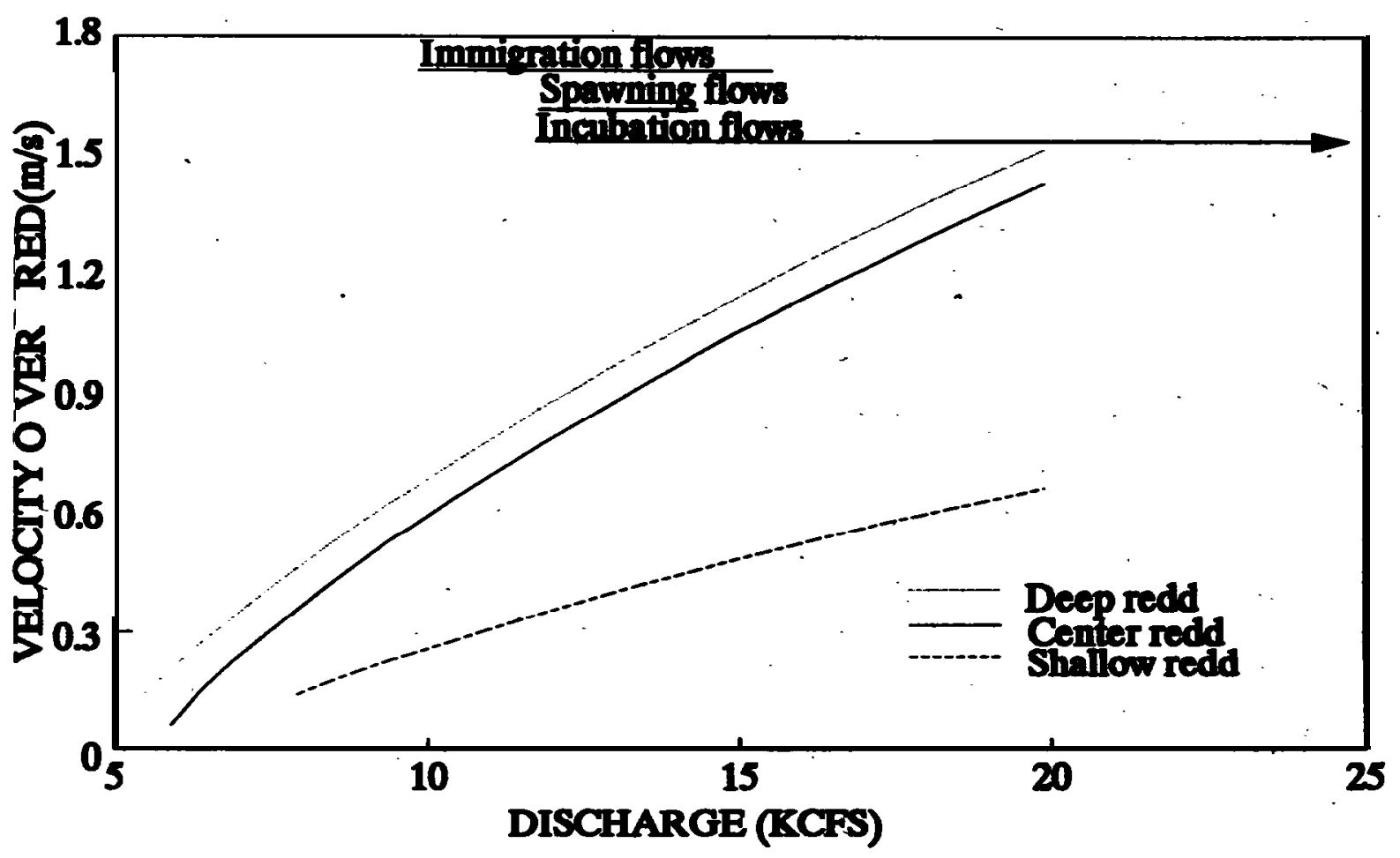

Fizure 9. Whater velocities at points representing the cepter of the spawning site at RK 261, the anglog ed so the pawning inte and the deep edge of tive spawning site, as modaled usitig IPG4. 


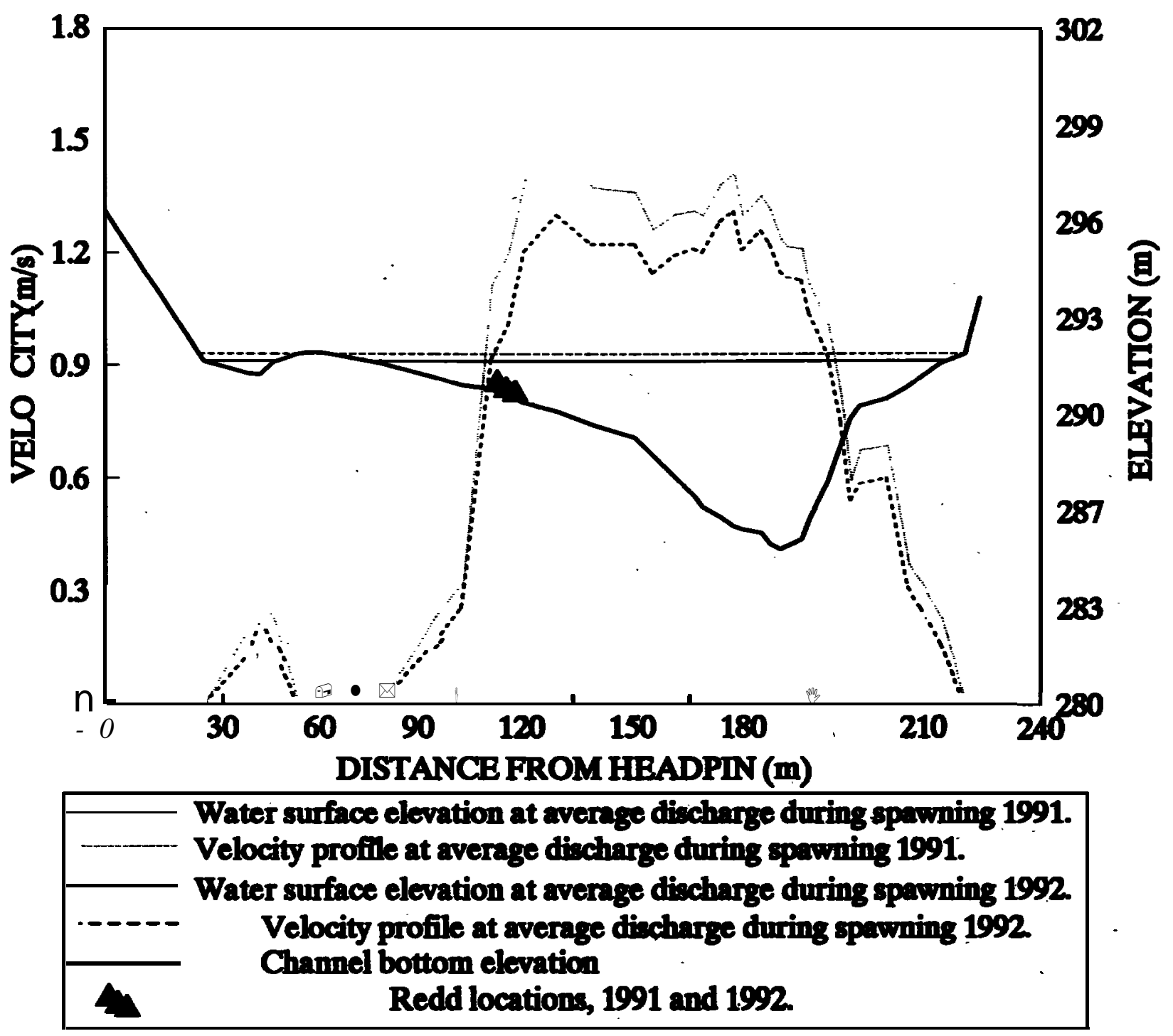

Figure 10.-Velocity profiles and water surfice elevations at cross section four at RK 261, as modeled using IFG4. 


\section{Discussion}

Snake River discharge during the 1992 fall chinook salmon brood year varied by life stage and differed from 1991 brood year flows. Flows in the 1992 brood year were generally lower than 1991 brood year during immigration, spawning, and early egg incubation. As fall chinook salmon fry of the 1992 brood year began to emerge flows increased dramatically and exceeded 1991 brood year flows by an average of $40 \mathrm{KCFS}$. As in the 1991 brood year (Connor et al. 1993), the operation of Hells Canyon Complex dominated the shape of the Snake River's flow regime at Anatone gage (RK 270). Consequently, the ongoing effort of the Idaho Power Company (IPCo) to prevent fall chinook salmon redd dewatering between Hells Canyon Dam and the mouth of the Salmon River (RK 302) appears to have had positive effects as far downriver as Anatone gage (RK 270). As in the 1991 brood year (Connor et al. 1993), flows increased to their highest level during the spawning period on the last day of fall chinook salmon redd counts (12 December). The 12 December increase in 1992 appears to have been related to Salmon River flows and resulted in a discharge at Anatone gage of 14.3 KCFS. Discharge at Anatone gage fell below 14.3 KCFS often during fall chinook egg incubation prior to 17 March, but the greatest difference was only 1.2 KCFS. After 17 March, high spring flows commenced and there was no danger of redd dewatering through the end of fall chinook salmon fry emergence in June.

We found that snake River water temperatures during the 1992 fall chinook salmon brood year were similar to those of the 1991 brood year until the snow melt and rainfall of early spring began about 17 March. After 17 March, the cooler egg incubation conditions of brood year 1992 had major effects on the timing of fall chinook salmon fry emergence in the spring of 1993. To date, we know of no calibrated temperature model capable of showing the effects of Hells Canyon Complex on fall chinook salmon egg incubation rate in the the snake River.

We developed models to predict the effects of flow on fall chinook salmon spawning habitat in 1992-1993. To demonstrate our progress with the models we presented results from a complicated fall chinook salmon spawning study site at RK 261. These results illustrate a number of important points. We determined that the errors associated with flow gaging done without being attached to a fixed cable were mathematically correctable. Furthermore, the model we calibrated with the above data simulated depths and velocities accurately when compared to measured data. Our confidence in the modelling results is furthered by a comparison to the data of Groves (1993). Groves measured depth and mean column velocity directly over 10 of the fall chinook salmon redds at $\mathrm{RK} 261$ in 1992. The range of depths $(0.7-1.4 \mathrm{~m})$ measured by Groves corresponded closely to the range of depths predicted for 
representative points within the spawning area by our model (0.5$1.2 \mathrm{~m})$. Likewise, the mean column velocities $(0.7-1.2 \mathrm{~m} / \mathrm{s})$ measured by Groves over fall chinook redds were similar to those representative points we modelled (0.4-1.1 m/s). Accurate hydraulic models of fall chinook spawning sites will help isolate the physical features of areas that attract spawners on a consistent basis. In our reports (Connor et al. 1993, and Garcia et al. in this report), we discuss the occurrence of concentrated spawning at a few sites since 1987. To date there is no explanation for this phenomenon. An explanation of concentrated spawning will be necessary to estimate the production potential of the spawning sites in future reports. For the present, our calibrated model could be useful for describing the effects of flow alternatives on select fall chinook salmon spawning sites.

In conclusion, our findings during 1992 indicate: (1) Hells Canyon Complex dominated the flow pattern of the snake River downstream to RK 270; (2) the thermal regime of the snake River was colder during egg incubation and fry emergence during 1992 than during 1991; (3) our calibrated hydraulic model of RK 261 indicated that depths and velocities at RK 261 were different in 1991 and 1992 during spawning; and (4) our model predicted that the flow required to dewater the shallowest fall chinook redds at RK 261 would be 7.4 KCFS (gaged at RK 270), which is well below any actual flow event which occurred during fall chinook salmon spawning or egg incubation of 1991 or 1992. Finally, the information we have presented in this chapter will be modified upon the analysis of additional data. 


\section{References Cited}

Bayha, K. 1974. Anatomy of a River Study: An evaluation of water requirements for the Hell's Canyon reach of the Snake River. Pacific Northwest River Basins Commission, Vancouver, Washington.

Bovee, K.D. 1982. A guide to stream habitat analysis using the Instream Flow Incremental Methodology. Instream Flow Information Paper 12, FWS/OBS-82/26, U.S. Fish and Wildlife Service, Office of Biological Services, Washington, D.C.

Brusven, M.A., 1977. Effects of sediments on insects. Page 43in D.C. Kibbee. Transport of granitic sediments in streams and its effects on insects and fish. USDA Forest Bulletin 17. Northwest Forest and Range Experimental Station, University of Idaho, Moscow.

Connor, W.P., A.P. Garcia, H.L. Burge, and R.H. Taylor. 1993. Fall chinook salmon spawning in free-flowing reaches of the Snake River. Pages 1-29 in D.W. Rondorf and W.H. Miller, editors. Identification of the spawning, rearing, and migratory requirements of fall chinook salmon in the Columbia River basin. 1991 Annual Progress Report (contract DE-AI79-91BP21708) to Bonneville Power Administration, Portland, Oregon.

Groves, P.A. 1993. Habitat available for, and used by, fall chinook salmon within the Hells Canyon Reach of the snake River. Annual Progress Report 1992. Environmental Affairs Department, Idaho Power Company, Boise, Idaho.

Milhous, R.T., M.A. Updike, and D.M. Schneider. 1989. Computer reference manual for the Physical Habitat Simulation system (PHABSIM)-Version II. U.S. Fish and Wildlife Service, National Ecology Research Center. Fort Collins, Colorado.

NMFS (National Marine Fisheries Service). 1992. Threatened status for Snake River spring/summer chinook salmon, threatened status for snake River fall chinook salmon. Final rule, April 22, 1992. Federal Register, Vol. 57, No. 78. 


\section{CHAPTER THREE}

Swimming performance of subyearling chinook salmon

by

W.R. Nelson, L.K. Freidenburg, and D.W. Rondorf National Biological Survey

Columbia River Research Laboratory

cook, Washington 98605, USA 


\section{Introduction}

Seasonal reductions in the swimming performance of juvenile salmon have been proposed as a behavioral mechanism that enables juvenile salmon to emigrate. The observed decrease in swimming performance and an analysis of migration rates led Smith (1982) to develop the paradigm that in the Columbia River, yearling salmonids migrate during part of a day by swimming upstream with the reduced performance. This paradigm may be applicable to the migratory behavior of juvenile fall chinook salmon Oncorhynchus tshawytscha. Relatively little is known about what factors might prompt the changes in swimming performance in preparation for seaward migration, but physiological readiness and environmental stimuli are possible factors. One factor in particular, the influence of flow on the timing and rate of emigration of fall chinook salmon in the Columbia River Basin has been controversial.

This laboratory study was initiated in 1991 to describe the swimming performance of juvenile fall chinook salmon and to estimate the influence of environmental and biological factors or directing and regulating their performance (Nelson et al. 1993). The objectives in 1992 were to provide additional information on whether juvenile fall chinook salmon emigrate actively or passively and the influence of flow, temperature, fish size, and smoltification level on their rate of emigration.

\section{Methods}

The basic study design and equipment remained the same as in 1991 (Nelson et al. 1993). Fish were subjected to increasing water velocities during the day and night and their swimming performance quantified. However, the source of fish used in the 1992 experiments was different from 1991.

\section{Fish Collection}

Subyearling chinook salmon were collected from McNary Pool and McNary and John Day dams. Twenty fish, assumed to be rearing in McNary Pool, were randomly selected from beach seine catches made every other week from 6 May to 30 June. The fish were transported about $300 \mathrm{~km}$ to the laboratory and transferred to the test flume. During transport, the fish were supplied with oxygen, and the water temperature at the time of collection was maintained to $\pm 2^{\circ} \mathrm{C}$. The fish were allowed to acclimate to the test flume at least $24 \mathrm{~h}$ before testing. Water velocity in the test flume during acclimation was $0-1 \mathrm{~cm} / \mathrm{s}$. Fish were not fed during this time. 
Twenty fish from McNary Dam were collected every other week from 10 June to 19 August, and 20 fish from John Day Dam were collected every other week from 14 July to 23 August. Fish collected at the dams were assumed to be emigrating. We selected 20 fish from a sample of fish passing through the dam's bypass system at the time of greatest passage, usually sunset. The fish were transported about $225 \mathrm{~km}$ from McNary Dam and $90 \mathrm{~km}$ from John Day Dam to the laboratory and transferred to the test flume. The same procedure used to transport and acclimate fish from McNary Pool was followed for fish collected at the dams.

Incandescent lighting illuminated the test flume. A fixed photoperiod of 0500 to 2000 hours (15 h daylight, 9 h dark) was maintained throughout the testing period. Crepuscular lighting occurred twice a day for $1 \mathrm{~h}$ (0400 to 0500, 2000 to 2100 hours). The fixed photoperiod wa used to ensure sufficient time for the fish to acclimate to complete darkness prior to the night swimming trials and to ensure complete darkness during the trials. Light intensity varied from $1-4$ lumens in the day and 0.02-0.07 lumens at night.

The test flume was supplied with well water which flowed through a $50 \mathrm{~kW}$ three phase single pass water heater. Water temperature was adjusted to follow the water temperature at the collection sites. During the testing period water temperature ranged from $11.5-18 \cdot 3^{\circ} \mathrm{C}$.

\section{Laboratory Set-up}

The test apparatus was a $36-\mathrm{cm}$ wide by $35-\mathrm{cm}$ deep circular flume located at the circumference of a 366-cm diameter fiberglass tank (Figure i). A 7.5 horsepower pump connected to an adjustable frequency drive circulated water through 4 sets of $1.3-\mathrm{cm}$ PVC pipes containing nine openings directed into the flume. Shade was provided by two covered 48.3 x 121.9-cm areas opposite from each other. Visual reference points were provided by two sets of six black lines about $5.0-\mathrm{cm}$ wide and $7.6-\mathrm{cm}$ apart painted on the flume bottom opposite from each other. An infrared sensitive camera was mounted above the flume, and an infrared light was used at night for illumination; reflective tape was placed beneath the camera on the flume bottom to increase available light. A black line painted across the reflective tape divided the flume into three equal sections denoting the inner, middle, and outer sections (Figure 1). This reference line was essential in counting the fish. AVHS record/playback machine and monitor were used to monitor and record fish behavior.

Water velocity was measured in the center of the flume. The velocity meter, monitor, and record/playback machine were located in an adjacent room to minimize disturbing the fish during tests. 


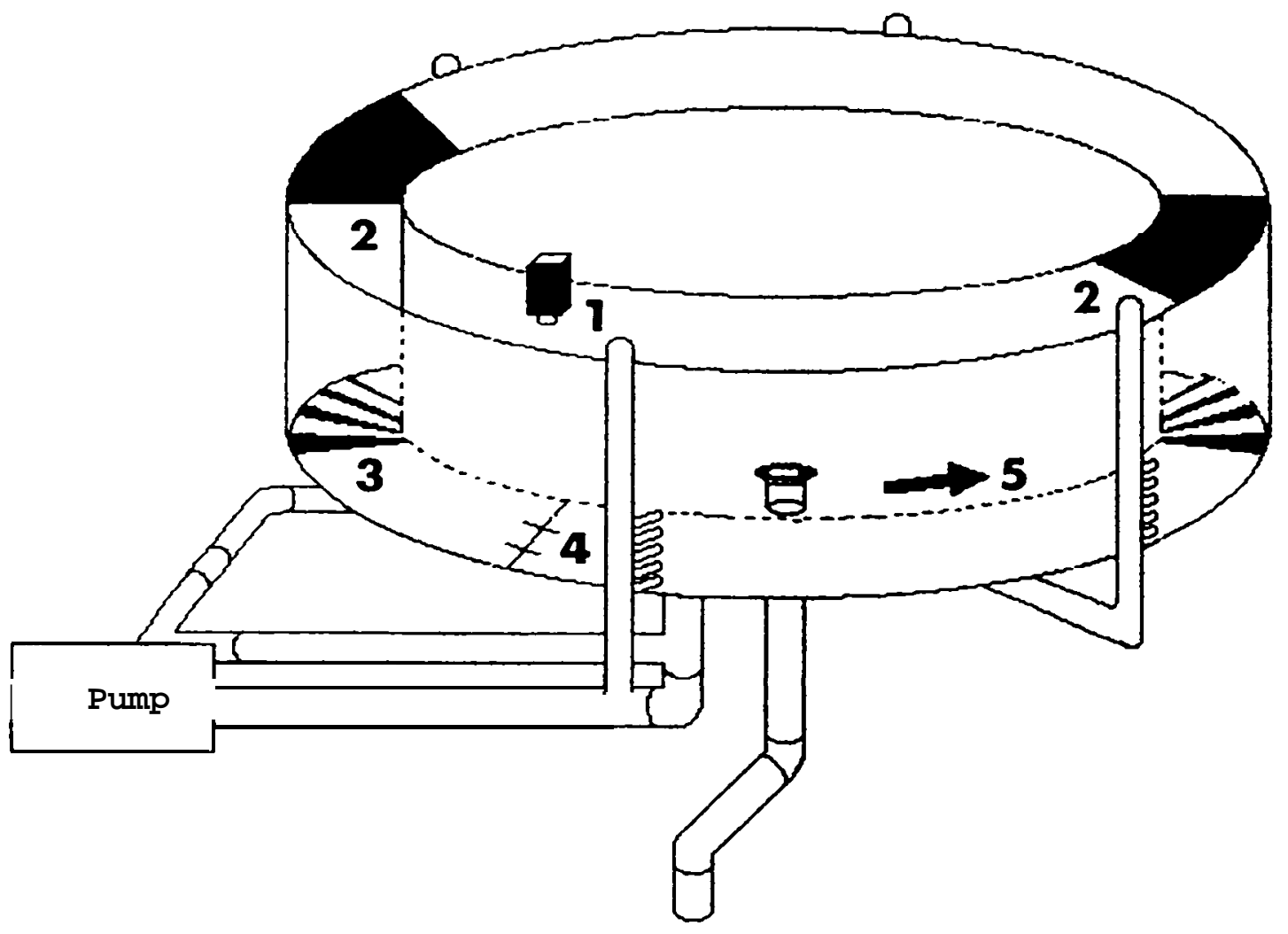

1-camera

2-shaded areas

3-visualorientationlines 4-reference line

5-direction of water flow

Figure.1-An overview of the experimental design: the test tank and associated plumbing. 


\section{Experimental Protocol}

Identical swimming trials were conducted during the day and night. The night trials began after $1 \mathrm{~h}$ of darkness. The fish were subjected to progressively increasing water velocities of 5, $10,15,20,25,30,40$, and $50 \mathrm{~cm} / \mathrm{s}$ in a $4 \mathrm{~h}$ period. Each velocity was maintained for $30 \mathrm{~min}$; the first $15 \mathrm{~min}$ allowed the velocity to stabilize, and during the second $15 \mathrm{~min}$ the fish were videotaped. The day trials began $8 \mathrm{~h}$ after completion of the night trials. Upon completing the day trial the fork length, weight, and a gill sample were obtained from each fish. Gill $\mathrm{Na}^{*}, \mathrm{~K}^{*}$-ATPase activity was measured according to Zaugg (1982).

\section{Data Collection and Analysis}

Five randomly selected 1.5 min intervals from each 15 min taping period were used to quantify the swimming velocity of the fish. The number of fish passing the reference line was counted. The orientation (i.e., swimming upstream-positive rheotaxis, swimming downstream-negative rheotaxis, and drifting) and distribution of the fish in the flume (i.e., inner, middle, and outer sections) were also recorded. The water velocity the fish experienced was estimated on the basis of their distribution in the flume, adjusting for a discrepancy in velocities of about $30 \%$ between the middle section and the inner and outer sections. The mean displacement velocity of the fish at each test velocity was calculated for each of the five counts at the eight velocities for a total of 40 observations per trial; mean swimming velocity of the fish was calculated by subtracting their displacement velocity from the water velocity. The swimming velocity of the fish was expressed in $\mathrm{cm} / \mathrm{s}$ and body lengths per second (bl/s) to facilitate comparisons among different sized fish. Pearson's correlation coefficients and bivariate-regression analysis were used to examine relations between variables with statgraphics software and multiple linear regression analysis was conducted using SAS software (SAS Institute 1988; Statgraphs 1992).

The hypothetical distance traveled by a fish in a $24-\mathrm{h}$ period during each paired day-night series conducted was calculated as:

$$
\mathrm{D}=\mathrm{a} \sum \mathrm{DVN}_{\mathrm{i}}+2 \mathrm{a} \sum \mathrm{DVD}_{\mathrm{i}} ;
$$

where $\mathrm{D}=\mathrm{kilometers}$ traveled per day, DVN = displacement velocity $(\mathrm{cm} / \mathrm{s})$ during night, DVD $=$ displacement velocity $(\mathrm{cm} / \mathrm{s})$ during day, $a=$ factor to convert $\mathrm{cm} / \mathrm{s}$ to $\mathrm{kilometers} / 8 \mathrm{~h}$, and $i=$ eight water velocity $(\mathrm{cm} / \mathrm{s})$ levels. The estimate was weighted on the basis of a 16-h day and 8-h night, which approximates the June-August photoperiod, and compared with the distance which would be traveled by passive drift at a water velocity of 24.4 $\mathrm{cm} / \mathrm{s}$, the mean of the eight water velocities to which the fish were subjected. 


\section{Results}

Subyearling chinook salmon collected by beach seining in McNary Pool were tested five times from 7 May to 2 July, fish from McNary Dam were tested five times from 25 June to 21 August, and those from John Day Dam were tested four times from 15 July to 25 August (Table 1). Water temperatures during the trials increased from about $13^{\circ} \mathrm{C}$ in early May to nearly $19^{\circ} \mathrm{C}$ by July where they remained through August.

The mean fork length of subyearling chinook salmon sampled in McNary Pool nearly doubled during the collection period, increasing from 4.8 to $9.4 \mathrm{~cm}$ for a mean daily increase in fork length of $0.8 \mathrm{~mm}$. The fish collected at McNary Dam exhibited less change in fork length, increasing from 10.7 to $12.7 \mathrm{~cm}$, and fish collected at John Day Dam increased from 11.8 to $12.9 \mathrm{~cm}$. Daily mean increase in fork length of the fish collected at McNary and John Day dams were $0.4 \mathrm{~mm}$ and $0.3 \mathrm{~mm}$, respectively.

The level of gill ATPase activity in the fish sampled increased from 10.1 umol $\mathrm{P}_{\mathrm{i}} / \mathrm{mg}$ protein/h (units) in early May to 39.6 units in mid June and then decreased to 10.6 units in late August (Table 1). Gill ATPase activity of fish sampled in McNary Pool increased rapidly in June and averaged 20 units. The fish sampled at McNary Dam had levels of gill ATPase which were nearly twice the level of those sampled at John Day Dam, averaging 24.4 and 13.9 units, respectively.

\section{Orientation and Distribution}

Among the subyearling chinook salmon from the three sites, positive rheotaxis was the most common orientation observed

(Table 2; Figure 2). Positive orientation was two times more common than negative orientation among fish collected at McNary Pool, nine times among fish collected at McNary Dam, and 21 times more common than negative orientation among fish collected at John Day Dam. Similarily, postive orientation was six times, 18 times, and 21 times more often observed than drift at McNary Pool, McNary Dam, and John Day Dam. Subyearling chinook salmon from McNary Pool and Dam exhibited significantly greater negative rheotaxis than drifting, but fish from John Day Dam did not exhibit any difference in the amount of negative rheotxis and drifting (Table 2).

The only tests during which fish exhibited significantly greater negative rheotaxis than positive rheotaxis or drifting was for fish collected in McNary Pool and tested on 21 May

(Figure 2). These fish also exhibited negative rheotaxis at low water velocities, but only at $10 \mathrm{~cm} / \mathrm{s}$ were the differences significant. In general, as water velocities increased the number of fish exhibiting positive rheotaxis increased (Figure 2). 
Table 1. Date and water temperature (T) when experiments were conducted and the number $(\boldsymbol{N})$, fork length (FL), weight (WT), gill $\mathrm{Na} \mathrm{K}^{*}$-ATPase activity level, and associated standard errors for the subyearling chinook salmon used in the experiments.

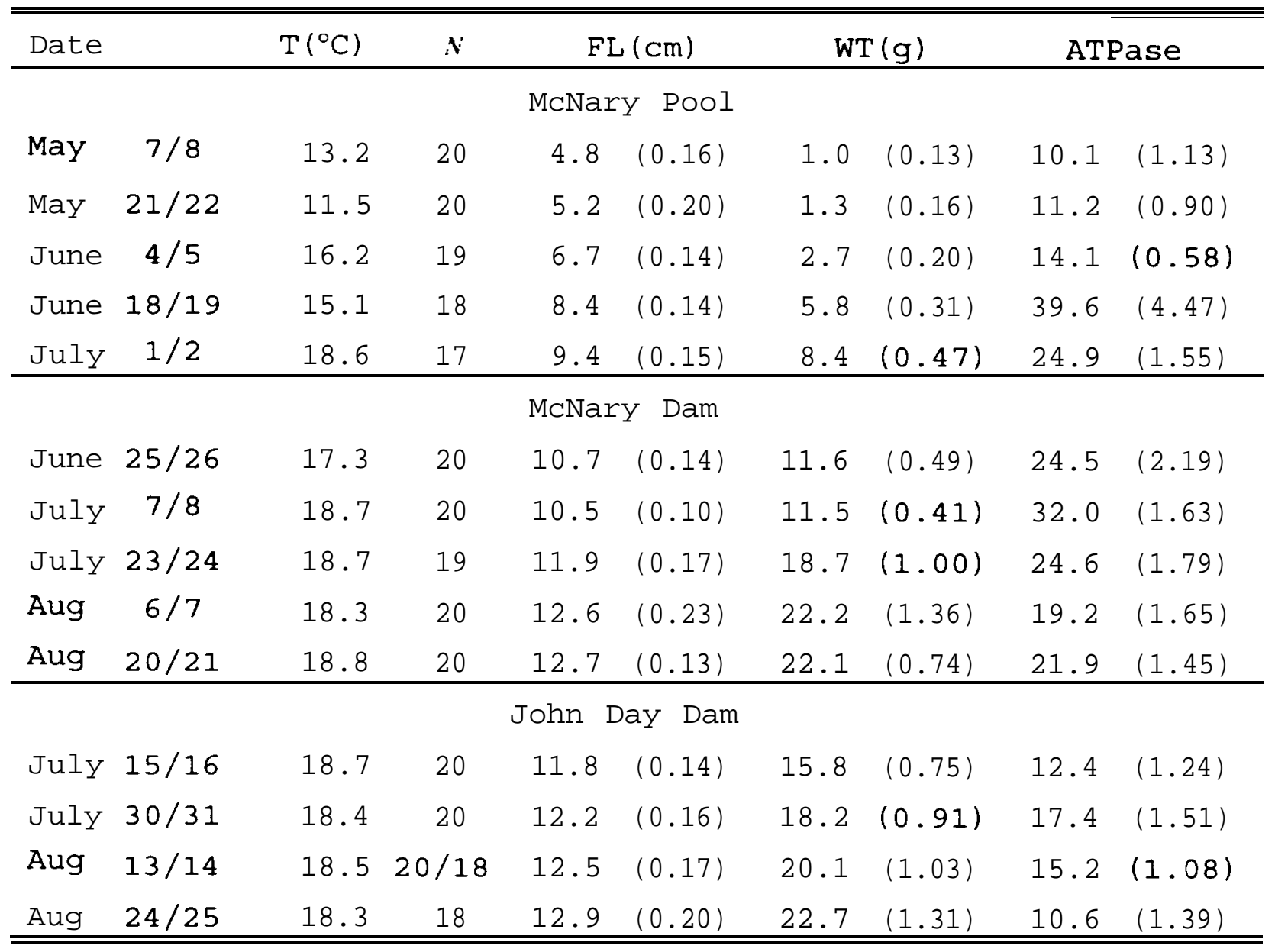


Table 2. Paired Student's r-test of the mean number per minute of subyearling chinook salmon in each orientation and their lateral distribution in the flume when they crossed the reference line. Symbols next to the r-value indicate the level of sianificance: $\star=P$ C $0.05: \star \star=P C 0.01$.

\begin{tabular}{|c|c|c|c|c|}
\hline \multirow[b]{2}{*}{ Orientation } & \multirow[b]{2}{*}{ Mean } & \multicolumn{3}{|c|}{ Orientation } \\
\hline & & Positive & Negative & Drift \\
\hline & & McNary Pool & & \\
\hline Positive & 13.9 & & $9.180 * *$ & $17.114 * \star$ \\
\hline Negative & 6.8 & & & $10.318 * *$ \\
\hline \multirow[t]{2}{*}{ Drift } & 2.3 & & & \\
\hline & & McNary Dam & & \\
\hline Positive & 11.3 & & $20.471 * \star$ & $18.972 * \star$ \\
\hline Negative & 1.2 & & & $3.688 \star \star$ \\
\hline \multirow[t]{2}{*}{ Drift } & 0.6 & & & \\
\hline & & John Day Dam & & \\
\hline Positive & 4.2 & & $10.168 * \star$ & $10.289 * \star$ \\
\hline Negative & 0.2 & & & 0.940 \\
\hline \multirow[t]{2}{*}{ Drift } & 0.2 & & & \\
\hline & & \multicolumn{3}{|c|}{ Distribution } \\
\hline Distribution & Mean & Outer & Middle & Inner \\
\hline & & McNary Pool & & \\
\hline Outer & 9.8 & & $3.606 * \star$ & $14.848 * \star$ \\
\hline Middle & 7.9 & & & $9.087 * \star$ \\
\hline \multirow[t]{2}{*}{ Inner } & 3.6 & & & \\
\hline & & McNary Dam & & \\
\hline Outer & 4.0 & & $2.860 \star \star$ & 0.607 \\
\hline Middle & 5.0 & & & $3.247 * \star$ \\
\hline \multirow[t]{2}{*}{ Inner } & 3.8 & & & \\
\hline & & John Day Dam & & \\
\hline Outer & 1.1 & & $3.142 \star \star$ & $3.831 * \star$ \\
\hline Middle & 1.6 & & & 1.267 \\
\hline Inner & 2.0 & & & \\
\hline
\end{tabular}




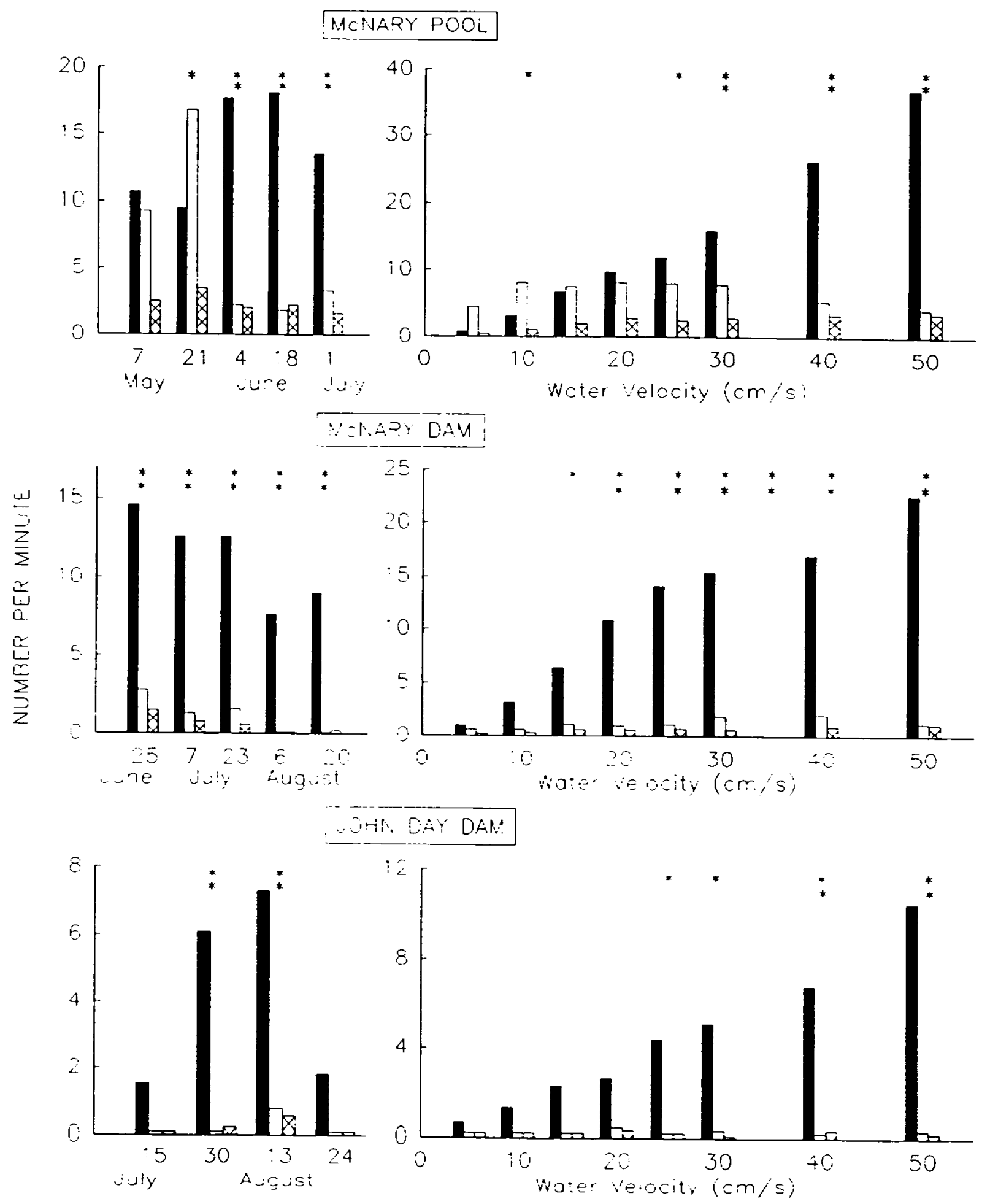

Figure 2. Number of subyecriing chinook salmon per minute passing the reference line displcying positive rheotoxis (D), negative rheotoxis ( or drifting (X) by date and wcter veiocity. Significance of chi-squcre test of random orientation $P<0.05=*$, $P<0.01={ }^{*}$. 
The lateral distribution of the subyearling chinook salmon in the test flume tended to change from the outer section to the inner section, an area of lower water velocities, as the fish were collected further downstream and as test water velocity increased (Table 2; Figure 3). The mean number of subyearling chinook salmon per minute distributed in the outer, middle, and inner sections of the flume was significantly different between all three sections for fish collected at McNary Pool. The highest number of fish were counted in the fastest moving water in the outer section of the flume with lesser counts in the middle or inner sections. Similarly, significantly more fish from McNary Dam were counted in the middle section than in the inner or outer sections. Fish from John Day Dam were distributed with significantly more fish in the middle and inner sections than the outer section of the flume.

\section{Swimming Velocity}

In general, the swimming velocity of the subyearling chinook salmon increased with water velocity and time within and among collection locations (Figure 4). The swimming velocity of the fish tested was less variable at night than during the day (Figure 4). The maximum swimming velocity, $28 \mathrm{~cm} / \mathrm{s}(5.9 \mathrm{bl} / \mathrm{s})$, for McNary Pool fish was observed during the first night trial at a water velocity of $50 \mathrm{~cm} / \mathrm{s}$. Thereafter, fish from McNary Pool rarely swam at velocities $>12 \mathrm{~cm} / \mathrm{s}$ (> $2 \mathrm{bl} / \mathrm{s}$ ) at night and never attained $22 \mathrm{~cm} / \mathrm{s}(3 \mathrm{bl} / \mathrm{s})$. During the day trials in May, fish from McNary Pool swam downstream at velocities $\leq-10 \mathrm{~cm} / \mathrm{s}(-2$ $\mathrm{bl} / \mathrm{s}$ ) when the water velocities were $\leq 25 \mathrm{~cm} / \mathrm{s}$ and they never attained swimming velocities of $10 \mathrm{~cm} / \mathrm{s}(2 \mathrm{bl} / \mathrm{s})$ at any water velocity tested. Fish tested during the day on 5 June swam at velocities equal to, or slightly higher than, water velocities when they were $<25 \mathrm{~cm} / \mathrm{s}$ and then swam at $<5 \mathrm{~cm} / \mathrm{s}(<0.7 \mathrm{bl} / \mathrm{s})$ at water velocities $>25 \mathrm{~cm} / \mathrm{s}$. In the day trials conducted on 19 June and 2 July, the fish exhibited the same behavior of swimming upstream at velocities sufficient to maintain their position until water velocities were $>30$ or $40 \mathrm{~cm} / \mathrm{s}$, respectively, and then changed to swimming c $10 \mathrm{~cm} / \mathrm{s}$ ( $<1 \mathrm{bl} / \mathrm{s}$ ) at higher water velocities.

Fish collected at McNary and John Day dams exhibited the general trend of increasing their swimming velocity with water velocity and date of the test (Figure 4). Bivariate regressions indicated water velocity explained 35\% and 99\% of the swimming velocity of fish collected at McNary and John Day dams respectively. Maximum swimming velocities of $42 \mathrm{~cm} / \mathrm{s}(3.4 \mathrm{bl} / \mathrm{s})$ at night and $59 \mathrm{~cm} / \mathrm{s}(5.0 \mathrm{bl} / \mathrm{s})$ during the day for McNary Dam fish and $47 \mathrm{~cm} / \mathrm{s}(3.6 \mathrm{bl} / \mathrm{s})$ at night and $54 \mathrm{~cm} / \mathrm{s}(4.6 \mathrm{bl} / \mathrm{s})$ during the day for John Day Dam fish occurred at water velocities of $50 \mathrm{~cm} / \mathrm{s}$. On $24 \mathrm{July}$, fish from McNary Dam tested during the day displayed the same behavior that had been observed for fish collected in McNary Pool; at a water velocity of $30 \mathrm{~cm} / \mathrm{s}$ the fish 


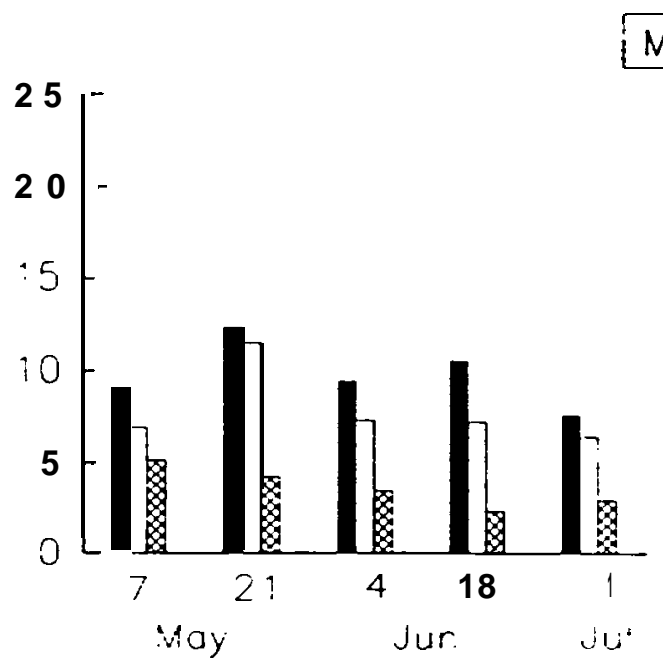

MCNARY POOL
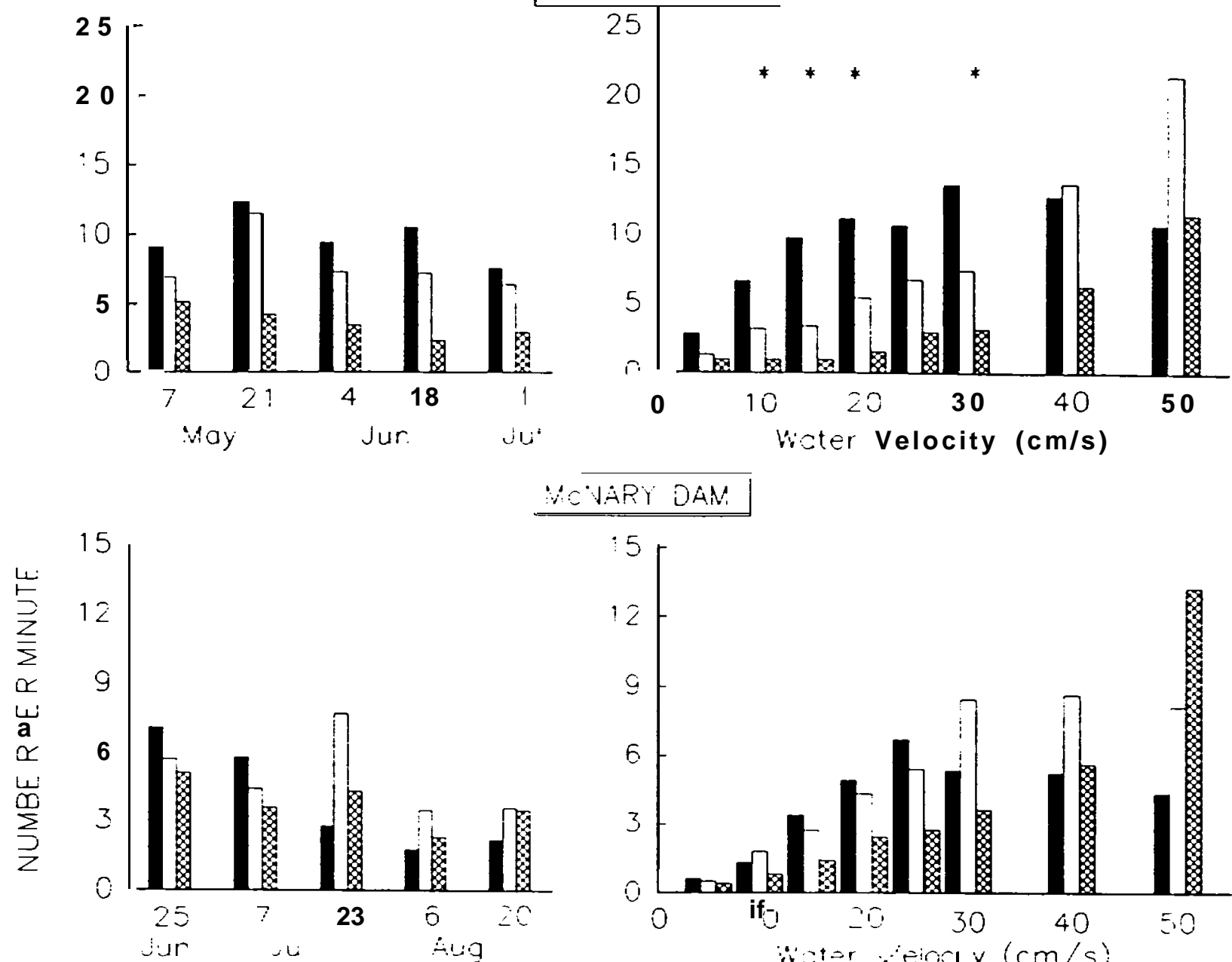

YOAARY DAN

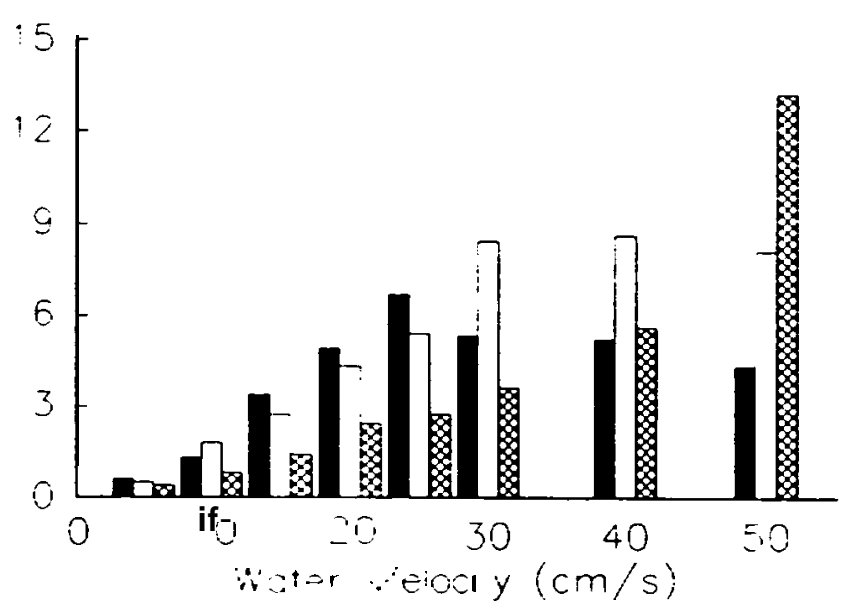

UHIN DAY DAM!
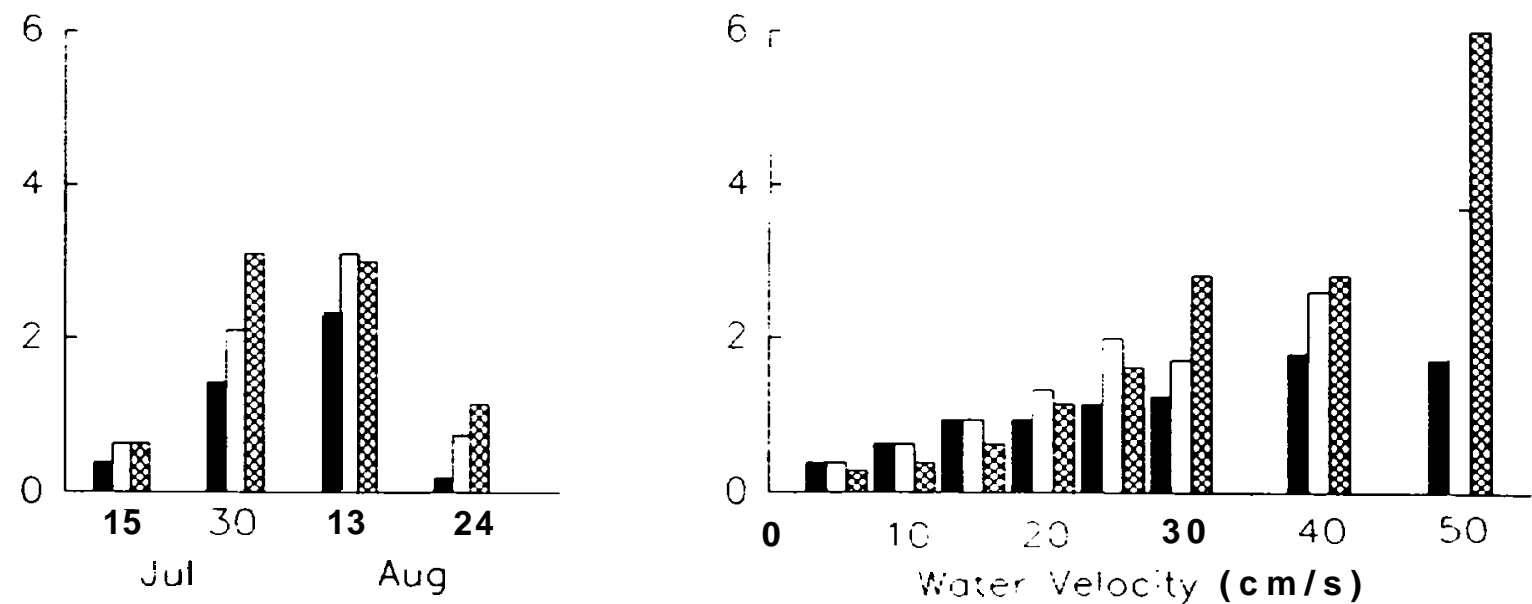

Figure 3. Number of sutyecring chinook solmon per minute possing the reference line distributed in the ovier ( $\square$ ), midcle ( portions of the flume by date ord wcter velocity. Signicance of chi-square test of random distribution $P<0.05=*$ 


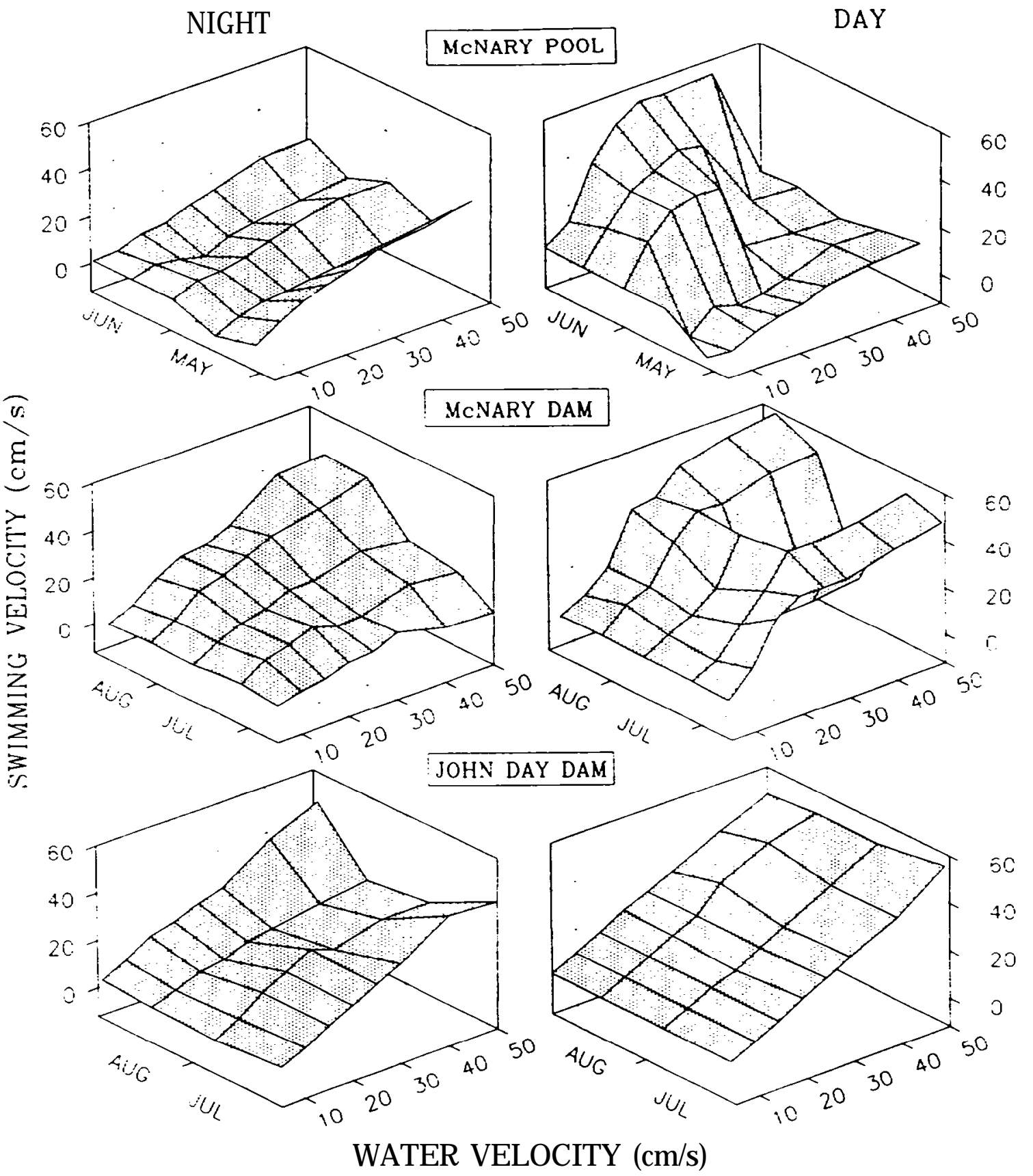

Figure 4. Swimming velocity of subyearling chinook salmon during the day and night at different water velocities by date and location of collection. 
changed from swimming upstream at velocities necessary to maintain their position to swimming $<6 \mathrm{~cm} / \mathrm{s}(<0.5 \mathrm{bl} / \mathrm{s})$ at water velocities $>30 \mathrm{~cm} / \mathrm{s}$.

The swimming performance observed for subyearling chinook salmon indicated they swam downstream primarily in May, during the day, at low water velocities. About 46\% of the fish tested from McNary Pool during May were observed to swim downstream during the day, but < 3\% of the fish from McNary Dam and none of the fish from John Day Dam exhibitited this behavior during the study. At night, about 16\% of the fish tested during May from McNary Pool swam downstream, but none of the fish from McNary and John Day dams swam downstream throughout the season. Of the fish collected in May from McNary Pool which swam downstream, 85\% of the observations during the day and all of the observations at night occurred at water velocities $\leq 25 \mathrm{~cm} / \mathrm{s}$.

\section{Displacement}

The mean day and night displacement rates for each test date from May through August were significantly correlated with water velocity used during the tests (Table 3). Downstream displacement rates in the test flume were negative early in the season during day and night, but neared zero displacement as day of the year, water temperature, and fork length increased throughout the season resulting in positive correlation coefficients with these variables (Table 3). Lunar phase and gill ATPase activity were not significantly correlated with mean displacement rates. The level of gill ATPase activity in fish sampled after 5 June was significantly correlated ( $\boldsymbol{r}=-0.800 ; \boldsymbol{P}$ $<0.01$ ) with displacement rate at night and the day-night mean ( $r$ $=-0.622, P<0.01)$, but not during the day $(\boldsymbol{r}=-0.114 ; \boldsymbol{P}>$

$0.05)$. In fact, deleting the 21-22 May results from the data set results in ATPase activity being significantly correlated $(\boldsymbol{r}=$ $0.614 ; P<0.05)$ with displacement velocity at night.

Further analysis suggested the behavioral response to specific variables may have changed throughout the season, and as fish were collected from downstream dams. The coefficients of determination of bivariate regression models indicated that water velocity explained 75\% of the variability in night displacement among fish collected from McNary Pool, 48\% for fish from McNary Dam, and 34\% for fish from John Day Dam (Figure 5). Displacement rates became increasingly negative at higher water velocities, resulting in an increased rate of downstream movement as water velocities increased (Figure 5). Water velocity did not explained the displacement velocity of fish tested during the day that were collected at McNary and John Day dams $(\boldsymbol{P}>0.05)$. Fish collected at McNary and John Day dams and tested during the day tended to maintain their position, or swim upstream, over the range of water velocities tested; whereas fish tested at night 
Table 3. Mean rate subyearling chinook salmon were displaced during the night and day for each test series and collection location correlated with environmental and biological factors. Correlation coefficient $(\boldsymbol{r})$ with $P<0.05=$ * and $P<0.01=$

\begin{tabular}{|c|c|c|c|}
\hline \multirow[b]{2}{*}{ Date } & \multirow[b]{2}{*}{ Location } & \multicolumn{2}{|c|}{ Displacement $(\mathrm{cm} / \mathrm{s})$} \\
\hline & & \multirow{2}{*}{$\frac{\text { Night }}{-10.8}$} & \multirow{2}{*}{$\frac{\text { Day }}{-27.3}$} \\
\hline May 7, 8 & McNary Pool & & \\
\hline May 21,22 & McNary Pool & -23.5 & -28.4 \\
\hline June 4,5 & McNary Pool & -16.6 & $-11 \cdot 3$ \\
\hline June 18,19 & McNary Pool & -23.9 & -4.9 \\
\hline June 25,26 & McNary Dam & -16.2 & 4.3 \\
\hline July 1,2 & McNary Pool & -17.6 & 5.6 \\
\hline July 7,8 & McNary Dam & $-12 \cdot 3$ & 7.1 \\
\hline July 15,16 & John Day Dam & -1.8 & 0.1 \\
\hline July 23, 24 & McNary Dam & -9.2 & $-11 \cdot 3$ \\
\hline July 30,31 & John Day Dam & -6.3 & 1.0 \\
\hline August 6,7 & McNary Dam & -2.5 & 8.2 \\
\hline August 13,14 & John Day Dam & -11.7 & 0.4 \\
\hline August 20,21 & McNary Dam & -3.2 & 10.5 \\
\hline August 24,25 & John Day Dam & -0.9 & 0.9 \\
\hline \multicolumn{2}{|l|}{ Variable } & Night & Day \\
\hline \multicolumn{2}{|c|}{ Julian Date } & $0.703 "$ & $0.755^{* *}$ \\
\hline \multicolumn{2}{|c|}{ Lunar Phase } & -0.091 & -0.077 \\
\hline \multicolumn{2}{|c|}{ Water Velocity } & $-0.666 "$ & $-0.356 "$ \\
\hline \multicolumn{2}{|c|}{ Water Temperature } & $0.623{ }^{\prime}$ & $0.863 "$ \\
\hline \multicolumn{2}{|c|}{ Fork Length } & $0.699^{\circ}$ & $0.811 "$ \\
\hline \multicolumn{2}{|c|}{ ATPase Activity } & -0.363 & 0.428 \\
\hline
\end{tabular}




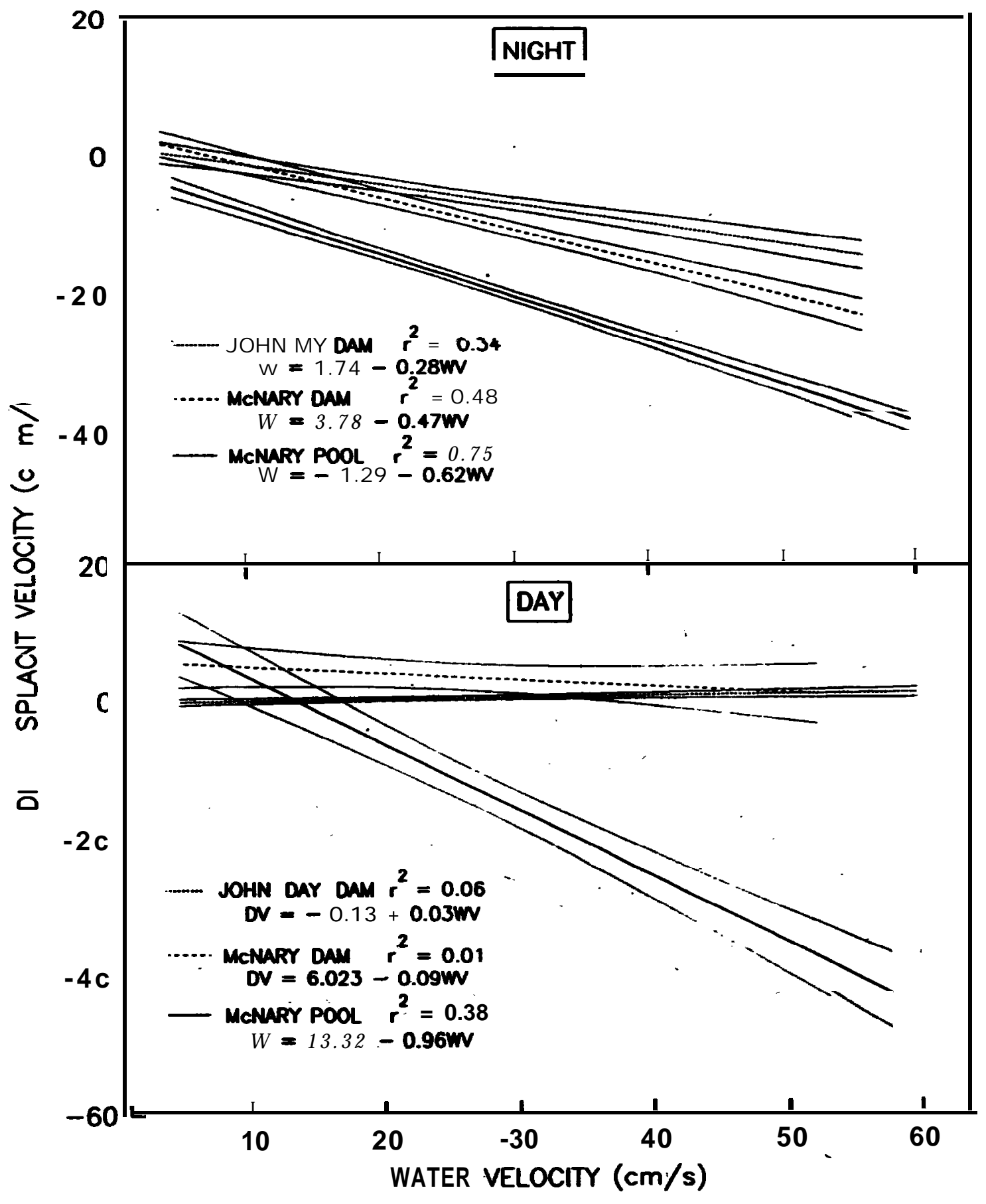

Figure 5. Relationship between displacement velocity of subyearling chinook salmon collected at different locations and the water velocity and time of day tested. 
were displaced, albeit slowly, when water velocities exceeded about $10 \mathrm{~cm} / \mathrm{s}$.

Multiple regression models explained 92\% of the variablility in displacement of subyearling chinook salmon from McNary Pool, 76\% for fish from McNary Dam, and 70\% for fish from John Day Dam (Table 4). Displacement rates were analyzed by day and night for each location because multiple regression analysis did not identify any significant independent variables to predict fish displacement during the day among fish collected from McNary and John Day dams $(\boldsymbol{P}>0.05)$. The stepwise regression routine selected water velocity first to explain displacement of fish during the daytime flume tests for fish collected at McNary Pool and for all night tests for fish collected at McNary Pool, McNary Dam, and John Day Dam.

Other variables entering the final multiple regression models of displacement rates included water temperature, fork length, gill ATPase, and a variable related to lunar phase (moon). Day of the year, weight, and a second variable related to moon phase were removed from the analysis because multicollinearity diagnostics indicated problems in the models. Inclusion of water temperature, fork length, and gill ATPase in the same model usually resulted in multicollinearity. The final model we selected to predict displacement among fish collected at John Day Dam included water velocity, gill ATPase, and number of days from the last new moon and had an $R^{\prime}=0.697$ (Table 4). A model using a logrithm transformation of displacement rate included water velocity, gill ATPase, the number of days to the nearest new moon, and fork length. The model using the logrithm transformed displacement values increased the $R^{2}$ to 0.779 , improved the Mallow's $\mathrm{C}$, and improved the multicollinearity diagnostics. However, we did not select that model because the increase in $R^{\prime}$ were not great, and interpretation of the biological significance was difficult.

In response to these displacement rates, the extrapolated distance a subyearling chinook salmon would be carried downstream in $24 \mathrm{~h}$ progressively decreased with time (Figure 6). At the mean test water velocity of $24.4 \mathrm{~cm} / \mathrm{s}$, drifting in the current would carry an object $21 \mathrm{~km}$ in $24 \mathrm{~h}$. The extrapolated distance a fish would move in an 8 -h night ranged from 0.2 to $7 \mathrm{~km}$ downstream. During a $16-\mathrm{h}$ day the distance was more variable, ranging from $16 \mathrm{~km}$ downstream to $6 \mathrm{~km}$ upstream. With the exception of fish collected at McNary Dam and tested on 23 and 24 July, the subyearling chinook salmon tested after 25 June would theoretically move downstream about $3 \mathrm{~km} / 24 \mathrm{~h}$ if the mean water velocity was $24.4 \mathrm{~cm} / \mathrm{s}$ (Figure 6 ). The reason the fish tested on 23 and 24 July moved downstream farther than other fish tested during this period was because the fish tested during the day swam $<6 \mathrm{~cm} / \mathrm{s}$ after the water velocity $>30 \mathrm{~cm} / \mathrm{s}$ rather than 
Table 4.-Multiple-regression models for predicting displacement of subyearling chinook salmon in a swim flume during day and night.

\begin{tabular}{|c|c|c|c|c|c|c|c|}
\hline \multirow[b]{2}{*}{ Location } & \multirow[b]{2}{*}{$\mathbf{N}$} & \multirow[b]{2}{*}{ Variable } & \multirow[b]{2}{*}{ Coefficient } & \multirow[b]{2}{*}{$\mathbf{P}$} & \multirow{2}{*}{$\begin{array}{c}\text { Beta } \\
\text { Coefficient }\end{array}$} & \multicolumn{2}{|l|}{ Partial } \\
\hline & & & & & & $R^{2}$ & $R^{2}$ \\
\hline \multicolumn{8}{|c|}{ Day } \\
\hline \multicolumn{8}{|c|}{ McNary Pool } \\
\hline & 40 & Constant & .36 .069 & 0.0006 & & & 0.681 \\
\hline & & Velocity & -0.954 & 0.0001 & -0.620 & 0.391 & \\
\hline & & Length & 7.143 & 0.0001 & 0.539 & 0.290 & \\
\hline \multicolumn{8}{|c|}{ McNary Dam } \\
\hline & 40 & & & N S & & & \\
\hline \multicolumn{8}{|c|}{ John Day Dam } \\
\hline & 32 & & & N S & & & \\
\hline \multicolumn{8}{|c|}{ Night } \\
\hline \multicolumn{8}{|c|}{ McNary Pool } \\
\hline & 40 & Constant & 20.625 & 0.0001 & & & \\
\hline & & Velocity & -0.610 & 0.0001 & -0.857 & 0.770 & 0.919 \\
\hline & & Moon & -0.701 & 0.0001 & -0.507 & 0.117 & \\
\hline & & Temperature & -1.056 & 0.0006 & -0.243 & 0.032 & \\
\hline \multicolumn{8}{|c|}{ McNary Dam } \\
\hline & 40 & Constant & -52.862 & 0.0001 & & & \\
\hline & & Velocity & -0.464 & 0.0001 & .0 .690 & 0.493 & 0.758 \\
\hline & & Length & 5.186 & 0.0001 & 0.490 & 0.229 & \\
\hline & & Moon & -0.239 & 0.0260 & -0.191 & 0.036 & \\
\hline \multicolumn{8}{|c|}{ John Day Dam } \\
\hline & 32 & Constant & 67.838 & 0.0001 & & & \\
\hline & & Velocity & -0.276 & 0.0001 & -0.585 & 0.356 & 0.697 \\
\hline & & ATPase & -3.888 & 0.0001 & -1.505 & 0.188 & \\
\hline & & Moon & -0.866 & 0.0008 & -1.141 & 0.154 & \\
\hline
\end{tabular}




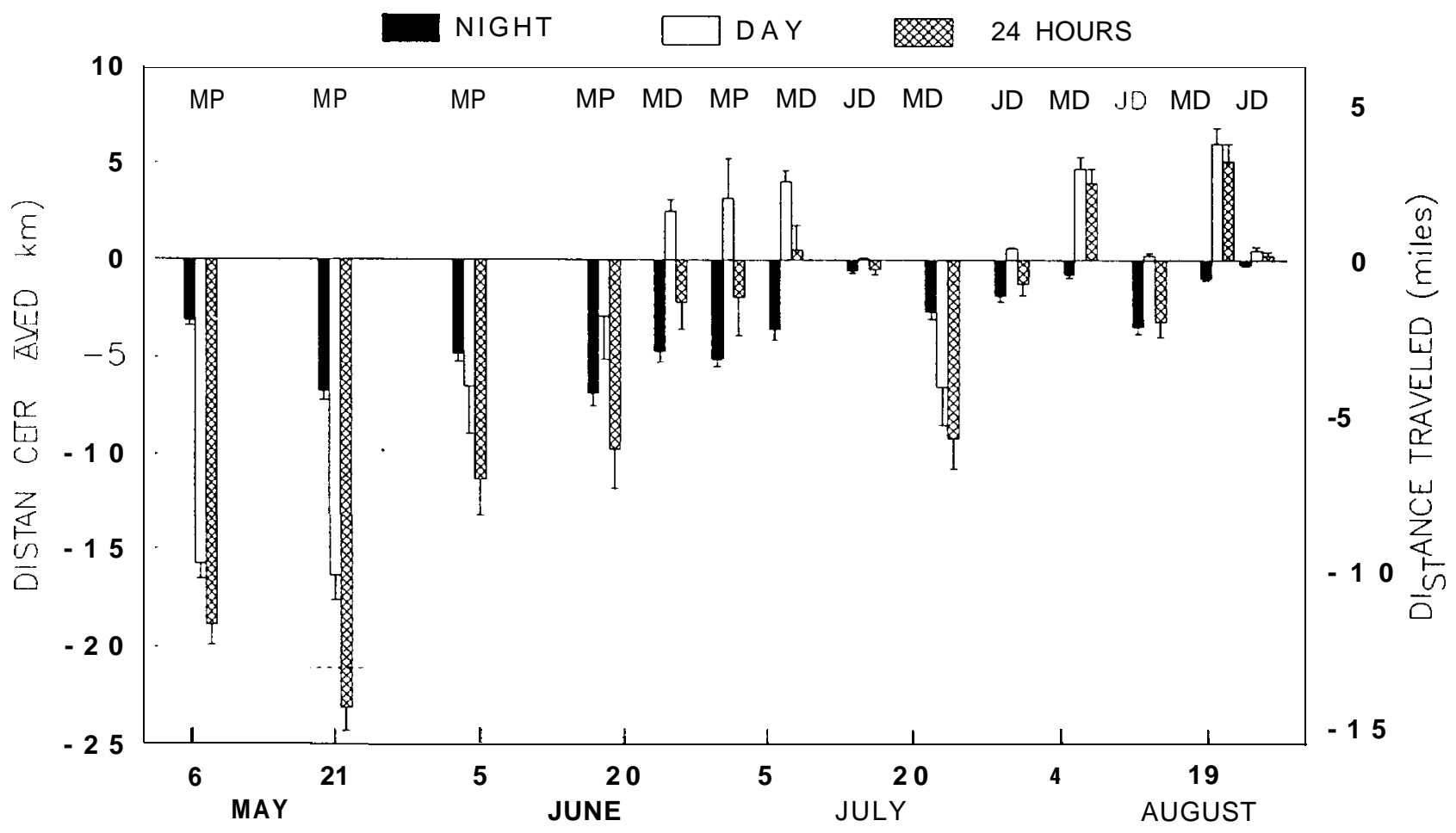

Figure 6. - Hypothetical mean (and SE) distance a subyearling chinook salmon collected at McNary Pool (MP), McNary Dam (MD), and John Day Dam (JD) would travel during an 8-h night, 16-h day, and 24-h period. The dashed line indicates the distance traveled in $24 \mathrm{~h}$ by passive drift at the mean water velocity tested. 
swimming at velocities similar to the water as did the other fish tested (Figure 4).

\section{Discussion}

The test conditions and origin of fish used in the swimming trials were selected to represent as closely as possible conditions that the stock of fall chinook salmon originating from the snake River are exposed to during their rearing and emigration. The range in test water velocities from 5 to $50 \mathrm{~cm} / \mathrm{s}$ are representative of water particle travel times which would result from discharges of about 12 to 124 KCFS (thousands of cubic feet per second) from Lower Granite Dam and 44 to $443 \mathrm{KCFS}$ from John Day Dam. Water temperatures during the swimming trials were maintained as closely as possible to ambient Columbia River water temperatures. Collection of subyearling chinook salmon in McNary Pool and at McNary and John Day dams provided fish covering a wide range in development. The fish sampled over the nearly four months of the study differed by as much as $8 \mathrm{~cm}$ in mean length, $21 \mathrm{~g}$ in mean weight, and nearly 30 units in mean gill ATPase activity. The fish sampled at McNary and John Day dams increased less in length than did the fish collected in McNary Pool. The greater length $(1-2 \mathrm{~cm})$ of fish captured from mid-June to early July at McNary Dam than in McNary Pool would indicate that larger fish in the population were emigrating from the reservoir.

Subyearling chinook salmon predominately swam upstream at rates comparable to the water velocity, thereby maintaining their position in the flume. Displacement downstream occurred during periods when at all water velocities the fish reduced their swimming velocity to $5-15 \mathrm{~cm} / \mathrm{s}(0.5-1.5 \mathrm{bl} / \mathrm{s})$, rates only sufficient to maintain their equilibrium in the current. Trump and Leggett (1980) estimated the optimum swimming speed in terms of energetic costs of fish migrating in currents would be about 1 bl/s. During all swimming trials the fish rarely drifted without locomotion in the water column, perhaps while not swimming they lose body control and the ability to rapidly move to capture food or evade predators.

Fish were observed to swim downstream only at water velocities c $15 \mathrm{~cm} / \mathrm{s}$ on 21 May, the period of their maximum displacement (Figures 2, 4). This behavioral response would be a logical evolutionary development to ensure emigrating fish swept into eddies or backwaters would return to higher velocity areas of the main channel. In addition, fish selected the highest water velocity in the outer section of the flume during the period when they were displaced the farthest, and were distributed in the inner section in the slower water when they exhibited minimal displacement (Figure 3). 
Throughout the study fish tended to swim slower, and more consistently, during the night than during the day (Figures 4, 5). This swimming performance resulted in the fish being displaced farther downstream in an $8 \mathrm{~h}$ night than a $16 \mathrm{~h}$ day on 10 of the 14 trials as would be expected for chinook salmon which are considered nocturnal migrants (Healey 1991). However, during four daytime tests the fish exhibited swimming behavior which, if repeated in the reservoirs, would result in greater displacement during the day than at night. The fish collected in McNary Pool during May exhibited the greatest potential displacement of all the fish tested because during the day they swam slowly at all water velocities (Figures 4, 6). Conversely, fish collected at McNary Dam during August exhibited a potential net upstream movement because during the day their swimming velocity exceeded the water velocity. This swimming behavior observed in the laboratory would result in a long residence time in John Day Pool unless the mean water velocity (i.e., water particle travel time) exceeded about $24 \mathrm{~cm} / \mathrm{s}$ (equivalent to a discharge rate of 216 KCFS at John Day Dam) and explains the reported recovery of marked fish upstream from their release location in this reservoir (Giorgi et al. 1990).

With the exception of subyearling chinook salmon tested on 21-22 May, the fish were never displaced downstream as far as they would be by drifting with the current (Figure 6). Fish on 21-22 May exceeded the theoretical distance traveled by drifting because they actively swam downstream during the day when the water velocities were $\leq 25 \mathrm{~cm} / \mathrm{s}$ (Figures 2 and 4 ). The observation that fish usually swam upstream explains why regression analysis of juvenile chinook salmon travel time on water velocity is always less than water particle travel time (Beeman et al. 1991; Buettner and Nelson 1992; Berggren and Filardo 1993). Our laboratory data indicates that only when fish were confronted with very low water velocities, during the time of their maximum disposition to migrate, would they actively swim downstream and exhibit travel times exceeding water particle travel time.

During some daytime tests the fish changed their behavior as the water velocities increased from swimming upstream at velocities comparable to the water velocity to swimming at velocities only sufficient to maintain their equilibrium (Figure 4). The water velocity at which this change in performance occurred increased from $25 \mathrm{~cm} / \mathrm{s}$ on 5 June to $40 \mathrm{~cm} / \mathrm{s}$ on $2 \mathrm{July}$ for fish from McNary Pool and at $30 \mathrm{~cm} / \mathrm{s}$ on $24 \mathrm{July}$ for fish from McNary Dam (Figure 4). Increases in water velocities at which the fish maintain position, or move upstream, during the day indicate a decrease in disposition to emigrate and significantly influences the distance a fish would be displaced downstream, 1.e., the higher the water velocities the fish maintain their position in the less they will be displaced (Figure 6). This same change in day time swimming performance was observed at 
water velocities $\geq 30 \mathrm{~cm} / \mathrm{s}$ in June 1991 for subyearling chinook salmon collected at Bonneville Dam (Nelson et al. 1993).

The change in swimming performance at water velocities of 25 to $40 \mathrm{~cm} / \mathrm{s}$ could be caused by fatigue or a change in behavior. Studies on various species, including salmonids, have indicated that the fish should not have become fatigued by the velocities in the length of time they were tested (Bainbridge 1962; Brett 1967; Beamish 1978;). During the tests conducted the night prior to the day trials, the same fish progressively increased their swimming velocities to $>20 \mathrm{~cm} / \mathrm{s}$ as the water velocity increased, whereas during the day they abruptly changed their performance from swimming at velocities $>40 \mathrm{~cm} / \mathrm{s}$ to swimming c $10 \mathrm{~cm} / \mathrm{s}$ (Figure 4). Irvine (1986) observed that the number of chinook salmon fry emigrating from experimental streams in New Zealand increased when water velocities exceeded $25 \mathrm{~cm} / \mathrm{s}$ and ottaway and Clarke (1981) estimated that water velocities of 26.5 to 42.5 $\mathrm{cm} / \mathrm{s}$ increased the downstream movement of brown trout Salmo trutta. Therefore, it appears that as water velocities exceed threshold levels of 25-40 cm/s, fish may change their behavior from holding position to emigrating, with the threshold water velocity increasing as fish lose their disposition to emigrate.

Subyearling chinook salmon exhibited their greatest disposition to emigrate during May and June when they were < 90 $\mathrm{cm}$ long (Figure 6, Table 1). In the Sacramento-San Joaquin, California and Situk, Alaska rivers, the southern and northern range limits of fall chinook salmon, the peak of emigration occurs from April to June and July to August (Kjelson et al. 1982; Johnson et al. 1992). Subyearling chinook salmon in the above rivers, and from others on the Pacific coast, migrate seaward when they are $70-80 \mathrm{~cm}$ in length (Healey 1980; Healey and Groot 1987; Healey 19911.

The rate at which fish in this study were displaced was significantly correlated with water velocity (i.e., the downstream displacement rates became increasingly negative as water velocity increased; Table 3). Studies by Berggren and Filardo (1993) demonstrated the time subyearling chinook salmon took to migrate between two locations in a reach decreased as river flow increased. Displacement rates were positively correlated with other variables, indicating less downstream displacement with later dates, higher water temperature, and increasing fish lengths (Table 3). various studies of other species of salmonids have shown that an increase in size and water temperature increases the fishes' swimming performance (Brett 1967; Beamish 1978). Therefore, the observed decrease in subyearling chinook salmon displacement caused by their increased swimming performance should be expected as their length and the water temperature increased during the study. 
Lunar phase and gill ATPase activity were related to displacement rate, but the relation was not as simple as other independent variables. Lunar phase has been reported to influence emigration rate of other salmonids (Grau 1982). Lunar variables were not significantly correlated with average displacement rates, but were significant independent variables in multiple regression models predicting displacement during night at specific water velocities. Beeman et al. (1991) reported the level of gill ATPase activity was significantly correlated with the travel time of yearling chinook salmon. We found maximum displacement occurred during May and June when gill ATPase activity was increasing and minimal displacement occurred as gill ATPase declined later in the season.

In summary, subyearling chinook salmon were displaced most rapidly during May and June when they were less than $9 \mathrm{~cm}$ in length and the water temperature was less than $16^{\circ} \mathrm{C}$. During displacement the fish swim upstream at about the optimum velocity of $1 \mathrm{bl} / \mathrm{s}$, or just fast enough to maintain body control. Rate of displacement was normally equal to water velocity minus the swimming velocity of about $1 \mathrm{bl} / \mathrm{s}$ so the higher the water velocity the more rapidly the fish were transported downstream. During the peak of emigration, fish are capable of moving substantial distances during the day as well as at night, the time when they usually are displaced the farthest. Fish actively swam downstream only at very low water velocities, when their disposition to migrate was maximum, and rarely drifted in the current. 


\section{References}

Bainbridge, R. 1962. Training, speed and stamina in trout. Journal of Experimental Biology 39:537-555.

Beamish, F.W.H. 1978. Swimming capacity. Pages 101-187 in W.S. Hoar and D.J. Randall, editors. Fish Physiology, Vol VII, Locomotion. New York, Academic Press.

Beeman, J.W., D.W. Rondorf, J.C. Faler, P.V. Haner, S.T Sauter, and D.A. Venditti. 1991. Assessment of smolt condition for travel time. Annual Report 1990 (contract DE-A179-87BP35245) to Bonneville Power Administration, Portland, Oregon.

Berggren, T.J., and M.J. Filardo. 1993. An analysis of variables influencing the migration of juvenile salmonids in the Columbia River basin. North American Journal of Fisheries Management 13:48-63.

Brett, J.R. 1967. Swimming performance of sockeye salmon (Oncorhynchus nerka) in relation to fatigue time and temperature. Journal of the Fisheries Research Board of Canada 24:1731-1741.

Buettner, E.W., and V.L. Nelson. 1992. Smolt monitoring at the head of Lower Granite reservoir and Lower Granite Dam. Annual Report 1991 (DE A179-83BP11631) to Bomnneville Power Administration, Portland, Oregon.

Healey, M.C. 1980. Utilization of the Nanaimo River estuary by juvenile chinook salmon, Uncorhynchus tshawytscha. U.S. National Marine Fisheries Service Fishery Bulletin 77:653-668.

Healey, M.C. 1991. Life history of chinook salmon (Oncorhynchus tshawytscha). Pages 313-393 in C. Groot and L. Margolis, editors. Pacific salmon life histories. University of British Columbia Press, Vancouver.

Healey, M.C., and C. Groot. 1987. Marine migration and orientation of ocean-type chinook and sockeye salmon. American Fisheries Society Symposium 1:298-312.

Giorgi, A.E., D.R. Miller, and B.P. Sanford. 1990. Migratory behavior and adult contribution of summer outmigrating subyearling chinook salmon in John Day reservoir, 1981-1983. Final report (contract DE-A179-83BP39645) to Bonnevillle Power Administration, Portland, Oregon. 
Grau, A.E. 1982. Is the lunar cycle a factor timing the onset of salmon migration? Pages 184-189 in E.L. Brannon and E.O. Salo, editors. Salmon and trout migratory behavior symposium. 1981. School of Fisheries, University of Washington, Seattle, Washington.

Irvine, J.R. 1986. Effects of varying discharge on the downstream movement of salmon fry, Oncorhynchus tshawytscha Walbaum. Journal of Fish Biology 28:17-28.

Johnson, S.W., J.F. Thedinga, and K.V. Koski. 1992. Life history of juvenile ocean-type chinook salmon (Oncorhynchus tshawytscha) in the Situk River, Alaska. Canadian Journal Fisheries and Aquatic Sciences 49:2621-2629.

Kjelson, M.A., P.F. Raquel, and F.W. Fisher. 1982. Life history of fall-run juvenile chinook salmon, Oncorhynchus tshawytscha, in the Sacramento-San Joaquin estuary, California. Pages 393411. In V.S. Kennedy, editor. Esturine comparisons. Academic Press, New York.

Nelson, W.R., L.K. Freidenburg, and D.W. Rondorf. 1993. Swimming behavior of subyearling chinook salmon. In D.W. Rondorf and W.H. Miller, editors. The spawning, rearing, and migratory requirements of fall chinook salmon in the Columbia River Basin. Annual report (contract DE-

A1791BP21708) to Bonneville Power Administration, Portland, Oregon.

Ottaway, E.M., and A. Clarke. 1981. A preliminary investigation into the vulnerability of young trout (Salmo trutta) and Atlantic salmon (Salmo salar) to downstream displacement by high water velocities. Journal of fish biology 19:135-145.

SAS Institute. 1988. SAS/STAT user's guide. Release 6.03, fourth edition, SAS Institute Inc., Cary, North Carolina.

Smith, L.S. 1982. Decreased swimming performance as a necessary component of the smolt migration in salmon in the columbia River. Aquaculture 28:153-161.

Statgraphics. 1992. Statgraphics Plus. Version 6. Manugistics, Inc., Rockville, Maryland.

Trump, C.L., and W.C. Leggett. 1980. Optimum swimming speeds in fish: the problem of currents. Canadian Journal of Fisheries and Aquatic Sciences 37:1086-1092:

Zaugg, W.S. 1982. A simplified preparation for adenosine triphosphatase determination in gill tissue. Canadian 
CHAPTER FOUR

Evaluation of PIT Tagging of Subyearling

Fall Chinook Salmon During 1991 and 1992

\section{by}

J.A. McCann and D.W. Rondorf National Biological Survey Columbia River Research Laboratory

Cook, Washington 98605, USA

and

H.L. Burge and W.P. Connor U.S. Fish and Wildlife Service Idaho Fishery Resource Office Ahsahka, Idaho 83520, USA 


\section{Introduction}

Subyearling chinook salmon Oncorhynchus tshawytscha naturally produced in the Hells Canyon Reach of the Snake River were tagged with passive integrated transponders (PIT) and recaptured at Lower Granite Dam to record time of emigration (Connor et al. 1993). PIT tags are ideal for these studies because they mark each fish uniquely so that individual fish can be monitored. Also, because they are internally planted, the hydrodynamics, camouflage coloration, and fins of fish are not affected. However, because the goal of this tagging was to better understand factors affecting their emigration, it was important to determine what effects tagging would have on subyearling chinook salmon behavior and survival. If PIT tagging significantly altered behavior, especially migratory behavior, then conclusions about their emigration drawn from PIT-tag recapture data could be erroneous. Furthermore, survival of tagged fish was a concern because the snake River fall chinook salmon stock had declined to such low numbers it was being considered for listing under the Endangered Species Act in 1991 and was listed as threatened in 1992. Tagging fish from this threatened population would be unacceptable if it caused high mortality.

Connor et al. (1993) anticipated that subyearling chinook salmon ranging from $55 \mathrm{~mm}$ to $70 \mathrm{~mm}$ would be readily captured by seine in nearshore habitats downstream from spawning areas in the Hells Canyon reach and, conversely, that larger fish would be widely dispersed in deeper habitats requiring large traps or weirs for capture. Therefore, if adequate numbers were to be tagged it would be necessary to implant tags in fish as small as $55 \mathrm{~mm}$ to $65 \mathrm{~mm}$ fork length. The direct or delayed mortality associated with the small size of fish we would be tagging and the possible aberrant migratory behavior following release were of concern to us as we prepared for the first year of this study. Therefore, we conducted a series of laboratory tests prior to field tagging.

During the development of PIT tags for use in juvenile salmonids considerable information was collected on the behavior and survival of fish after tagging (Prentice et al. 1990a). They measured growth, survival, and PIT-tag retention for subyearling chinook salmon with mean fork lengths ranging from 66 $\mathrm{mm}$ to $100 \mathrm{~mm}$; survival ranged from 95 to $100 \%$ for about $135 \mathrm{~d}$. Less than 12\% mortality $45 \mathrm{~d}$ after tagging was reported for juvenile steelhead O. mykiss with mean fork lengths $80 \mathrm{~mm}$ to $129 \mathrm{~mm}$ (Prentice et al. 1986). 
Although the results of Prentice et al. (1990a) did not demonstrate a relationship between fish size and tagging mortality rate or tag retention rate, the fish we would be tagging were smaller than those other investigators had tested. Because PIT tags are $12 \mathrm{~mm}$ long, we anticipated there would be a minimum fish size below which tagging would be lethal and that limit had not been determined.

In addition to delayed mortality following tagging, swimming performance and vulnerability to predation were of concern. During development and testing of the tag neither the tagging procedure nor the presence of the tag in the fish was found to have a significant effect on swimming performance (Prentice et al. 1990a). The mean lengths of subyearling chinook salmon Prentice et al. (1990a) tested was $67 \mathrm{~mm}$ and $89 \mathrm{~mm}$, considerably larger than the fish we were considering PIT tagging. Therefore, we added swimming performance to our premarking tests.

The purpose of these experiments was to (1) quantify the effects of PIT-tagging procedures on the survival of $55 \mathrm{~mm}$ to 70 $\mathrm{mm}$ subyearling chinook salmon, (2) evaluate swimming stamina as an indication of physical condition of the fish, and (3) evaluate the effects tagging had on complex behavior; in this case predator avoidance. This paper reports the results of experiments started in 1991 and completed in 1992.

\section{Methods}

All subyearling fall chinook salmon used in these experiments were of the upriver bright stock obtained from Little White Salmon National Fish Hatchery. The upriver bright stock of fall chinook salmon was selected as a surrogate experimental animal for the Snake River stock because they are closely related and were readily available. Experiments were conducted in 1991 and 1992. Methods varied from the first year to the second.

In preparation for tagging, fish were netted from a holding tank and placed in a bucket of water containing $26 \mathrm{mg} / \mathrm{L}$ tricaine methanesulfonate (MS-222) anesthetic. In 1991, ten to $15 \mathrm{fish}$ were anesthetized at a time while in 1992 only 6 to 8 fish were anesthetized at a time. Also in 1992, the anesthetic solution contained $0.1 \mathrm{~g}$ salt, $3.5 \mathrm{~g}$ baking soda and $1 \mathrm{ml}$ of polyproaqua (synthetic slime) per $3.8 \mathrm{~L}$ of water. Prior to tagging fish were removed from the bucket and weighed and measured. Fish were then held for tag insertion in a slit on a sponge. PIT tags used in these experiments were approximately $12 \mathrm{~mm}$ in length and $2 \mathrm{~mm}$ in diameter. Each PIT tag was inserted into a 12 gauge hypodermic needle prior to tagging. The needle was inserted into the fish so that the bevelled tip completely penetrated beneath the surface of the skin at a point on the midline of the ventral surface posterior to the pectoral fins. The tag was pushed out of the needle so it was positioned just beneath the skin anterior 
of the wound. Then the needle was backed out of the wound and the wound was swabbed with disinfectant. The fish was placed in aerated water to revive it from the anesthetic. These operations constituted the act of PIT tagging the fish and use of the word tagging in this paper refers to this process. Each fish required approximately $1 \mathrm{~min}$ and $30 \mathrm{~s}$ to tag after removal from the anesthetic; including weighing and measuring. In each type of test described below, PIT-tagged fish are referred to as treatment fish and fish without tags are controls.

\section{Predation Vulnerability}

The primary measure of relative performance in the predation vulnerability experiment was the number of treatment and control subyearling chinook salmon that were consumed by the predator, smallmouth bass Micropterus dolomieue. Treatment and control groups were simultaneously introduced into a tank holding four smallmouth bass and exposed to predation risk for $24 \mathrm{~h}$. Tanks in which the experiments were done measured $1.2 \mathrm{~m}$ in diameter. Four segments of $20 \mathrm{~cm}$ diameter polyvinyl chloride pipe were placed in each tank to provide structural diversity and cover. Water temperature in the tanks was $10^{\circ} \mathrm{C}$. In 1991 , groups of treatment and control fish were allowed either $0.5 \mathrm{~h}$ or $96 \mathrm{~h}$ recovery time prior to predation exposure while in 1992, fish were allowed 0.5 $\mathrm{h}, 4 \mathrm{~h}$, or $24 \mathrm{~h}$ recovery. Control fish were held under the same conditions as treatment fish before introduction into tanks where experiments were conducted. Subyearling chinook salmon used in 1991 predation experiments ranged in fork length from $48 \mathrm{~mm}$ to 73 $\mathrm{mm}$ with a $59 \mathrm{~mm}$ mean fork length. In 1992, fork lengths ranged from $60 \mathrm{~mm}$ to $74 \mathrm{~mm}$ with a $64 \mathrm{~mm}$ mean. Smallmouth bass chosen randomly from a holding tank were given at least $24 \mathrm{~h}$ to acclimate to the tanks prior to introducing subyearling chinook salmon. Smallmouth bass were not fed during the acclimation period. Smallmouth bass fork length ranged from $199 \mathrm{~mm}$ to 268 $\mathrm{mm}$; weight ranged from $111 \mathrm{~g}$ to $242 \mathrm{~g}$. At the beginning of each predation experiment 32 treatment and 32 control fish were simultaneously introduced into the tank. After $24 \mathrm{~h}$ all survivors were removed, weighed, measured, and identified as treatment or control fish by examining their ventral surface for insertion scar and scanning with a PIT-tag detector (Prentice et al. 1990b). Predators were also weighed and measured at the end of each $24 \mathrm{~h}$ test. Three replicates of the predation experiment were conducted for $0.5 \mathrm{~h}$ and $96 \mathrm{~h}$ recovery groups in each of the trials that started 10 May and 17 May 1991. In 1992, three replicates of each experiment were also conducted for $0.5 \mathrm{~h}, 4 \mathrm{~h}$, and $24 \mathrm{~h}$ recovery groups during each of the trials that began 4 May and 11 May 1992 .

Chi-square goodness of fit tests were used to compare the number of treatment and control fish eaten to the expected number eaten in each group within each tank. The null hypothesis was that prey selection by smallmouth bass did not vary from random 
feeding. Alternatively, the hypothesis was stated as an

expression of prey vulnerability; treatment or control fish were not consumed in greater numbers than their relative proportion in the tank; $0.5 \mathrm{~h}, 4 \mathrm{~h}, 24 \mathrm{~h}$, and $96 \mathrm{~h}$ recovery tests were analyzed separately. Chi-square heterogeneity tests were applied to data for all tanks of a recovery group to test whether the proportion of treatment and control fish eaten varied among tanks. Where heterogeneity was not significant, data from all tanks of that recovery period were pooled and an overall chisquare test used. Size 'selectivity of treatment fish by predators was tested using a Kolmogorov-Smirnov test; the cumulative length frequency distribution of surviving treatment fish was compared to that of treatment fish initially introduced into the tanks.

We also conducted tests to compare the vulnerability of sham-tagged fish to control fish. Fish were sham tagged by inserting the tag injection needle into their abdomen without inserting a PIT tag. Equal groups of 32 sham-tagged fish and 32 controls were subject to predation as described for other predation tests. Results were analyzed using chi-square tests to determine if predators were selectively depredating sham or control fish as was done for the PIT-tag tests.

\section{Swimming Stamina}

Swimming stamina of subyearling chinook salmon was estimated using a Blazka respirometer (Blazka et al. 1960). Swimming stamina was determined after fish were allowed a post-tagging recovery period. In 1991, recovery periods were $0.5,4,24,48$, or $96 \mathrm{~h}$ while in 1992, they were $0.5,4$, or $24 \mathrm{~h}$. After recovery, six fish were selected randomly from control and treatment fish holding tanks. Fish from each group were placed in two separate compartments of a swim chamber. To keep track of individual fish, each was identified by unique natural markings, such as parr marks.

The swim chamber was calibrated prior to testing by placing a Marsh-McBirney water velocity meter in the swim chamber to measure water velocity. Water flow was generated by an impeller at the rear end of the swim chamber which was turned by a variable speed electric motor. Impeller turning speed was measured by a tachometer. A plot was generated of flow velocities measured by the flow meter in the swim chamber and the revolutions per second of the impeller. The tachometer was then used during the course of the swim tests to indicate water velocity in the swim chamber.

An electrified grid at the downstream end of the swim chamber was used to stimulate fish to swim to exhaustion. Black plastic was wrapped around the central portion of the swim 
chamber and the downstream end of the chamber was illuminated with a $100 \mathrm{~W}$ light to discourage fish from seeking refuge from velocity in front of the electrified grid.

Fish were given $0.5 \mathrm{~h}$ to acclimate in the swim chamber before testing began. Those fish held for the $0.5 \mathrm{~h}$ recovery period were placed in the swim chamber immediately after tagging and allowed to acclimate. During the first replicate of swim performance tests, in 1991, water temperatures at the end of the swim tests were $13^{\circ}$ to $14^{\circ} \mathrm{C}$ due to low volume of water circulation. Water temperature during the second replicate of swim tests was held between $10.4^{\circ}$ and $11.6^{\circ} \mathrm{C}$ by circulating fresh water through the chamber. Water temperatures for the 1992 swim tests were held between $10.0^{\circ}$ and $11.0^{\circ} \mathrm{C}$. Water velocity for each swim test began at 1.5 body lengths per second (bl/s) and was increased $0.5 \mathrm{bl} / \mathrm{s}$ every $15 \mathrm{~min}$. One body length was defined as $60 \mathrm{~mm}$ although fish ranged in length from $49 \mathrm{~mm}$ to $63 \mathrm{~mm}$. Tests were continued until all fish were fatigued. A fish was considered fatigued when it lodged against the grid.

Time of fatigue, U-critical, was calculated for each fish using the following formula from Beamish (1978) : U-critical $=U_{i}+\left(t_{i} / t_{i i} * U_{i i}\right) ;$ where, $U_{i}=$ highest velocity increment during which fish was not fatigued, $U_{i i}=$ velocity increment $(0.5 \mathrm{bl} / \mathrm{s}), \quad t_{i}=$ time (min) fish swam during final increment, and $t_{i i}=$ time period of each increment (15 min).

A general linear model analysis of variance (ANOVA) was used to analyze the importance of tagging and recovery period on swim performance. The general linear model was used because of the unbalanced design of the experiment (SAS 1988). Three other variables, chamber position, experimental replicate, and fork length, were included in the analysis to determine what effects each had upon the swim test results. Mean U-criticals for treatment and control groups in each trial were also compared using the Tukey method for t-tests to further analyze the importance of recovery period for each trial.

\section{Tag Retention and Dalayed Mortality}

Treatment and control subyearling chinook salmon were held in separate $0.5 \mathrm{~m}$ diameter tanks for $96 \mathrm{~h}$ after tagging to assess mortality. Water temperature in the tanks was $10^{\circ} \mathrm{C}$. Two groups of $40 \mathrm{fish}$ were anesthetized and tagged and then held in separate tanks. Two groups of 40 control fish were also held in separate tanks identical to those holding the tagged fish. Fish were not fed during the $96 \mathrm{~h}$ they were held. In the first trial, the mean fork length of treatment fish was $57 \mathrm{~mm}$ compared to $55 \mathrm{~mm}$ for the control fish. During the second trial, mean fork length of treatment fish was $63 \mathrm{~mm}$ and the mean fork length of control fish 
was $60 \mathrm{~mm}$. Tanks were checked 24, 48, 72, and $96 \mathrm{~h}$ after PIT tagging. All dead fish were removed, counted, weighed, and measured. Fish from the treatment groups were examined for tags. At the end of $96 \mathrm{~h}$ all fish were removed from the tanks, weighed, measured, and treatment fish checked for tag retention.

\section{Longterm Growth}

During 1992 laboratory experiments, we conducted a series of trials in which subyearling chinook salmon of the upriver bright stock were tagged and held for $44 \mathrm{~d}$. The tagging protocol was the same as used for the 1992 experiments described here. Groups of 100 treatment fish and 100 control fish were held in each of 3 rearing tanks. The arbitrary size groups were small fish $(50 \mathrm{~mm}$ to $59 \mathrm{~mm} \mathrm{FL})$; middle $(60 \mathrm{~mm}$ to $69 \mathrm{~mm} \mathrm{FL})$; and large (70 $\mathrm{mm}$ to 79 $\mathrm{mm}$ FL). At the outset of the trials the mean fork length of control groups were 56, 65, and $72 \mathrm{~mm}$ while treatment groups were 56, 64, and $72 \mathrm{~mm}$. The fish were stocked into tanks according to size group on 13 May, and 50 fish from each tag group were weighed and measured on 4 June, 25 June, and 28 July. Mean fork length of treatment and control groups was compared for each measurement period within each tank using the Tukey method of comparison (SAS 1988).

Results

\section{Predation Vulnerability}

During the $19910.5 \mathrm{~h}$ recovery tests, smallmouth bass consumed a larger proportion of treatment fish than control fish in all tanks (Figure 1). The heterogeneity chi-square test comparing the proportion of treatment and control fish eaten in all tanks was not significant for the $0.5 \mathrm{~h}$ recovery tests. Therefore, data were pooled from all six tanks of the $0.5 \mathrm{~h}$ recovery replicates and the pooled chi-square calculated (Sokal and Rohlf 1981). The pooled chi-square was significant indicating that a greater proportion of treatment fish were eaten than would be expected if predation was random. Additionally, individual chi-square tests for three of the six $0.5 \mathrm{~h}$ recovery tanks showed a significant difference in the number of treatment and control fish that were eaten (Table 1).

During 1991 tests, when the subyearling chinook salmon were allowed $96 \mathrm{~h}$ to recover prior to the predation test, there was no significant trend in feeding selectivity by smallmouth bass for either treatment or control fish (Figure 1). The chi-square test for heterogeneity was significant so that pooling the data for all six $96 \mathrm{~h}$ predation tanks was not appropriate. The number of treatment and control fish eaten was not significantly different in any tank of either trial one or trial two (Table 2). In 1992 


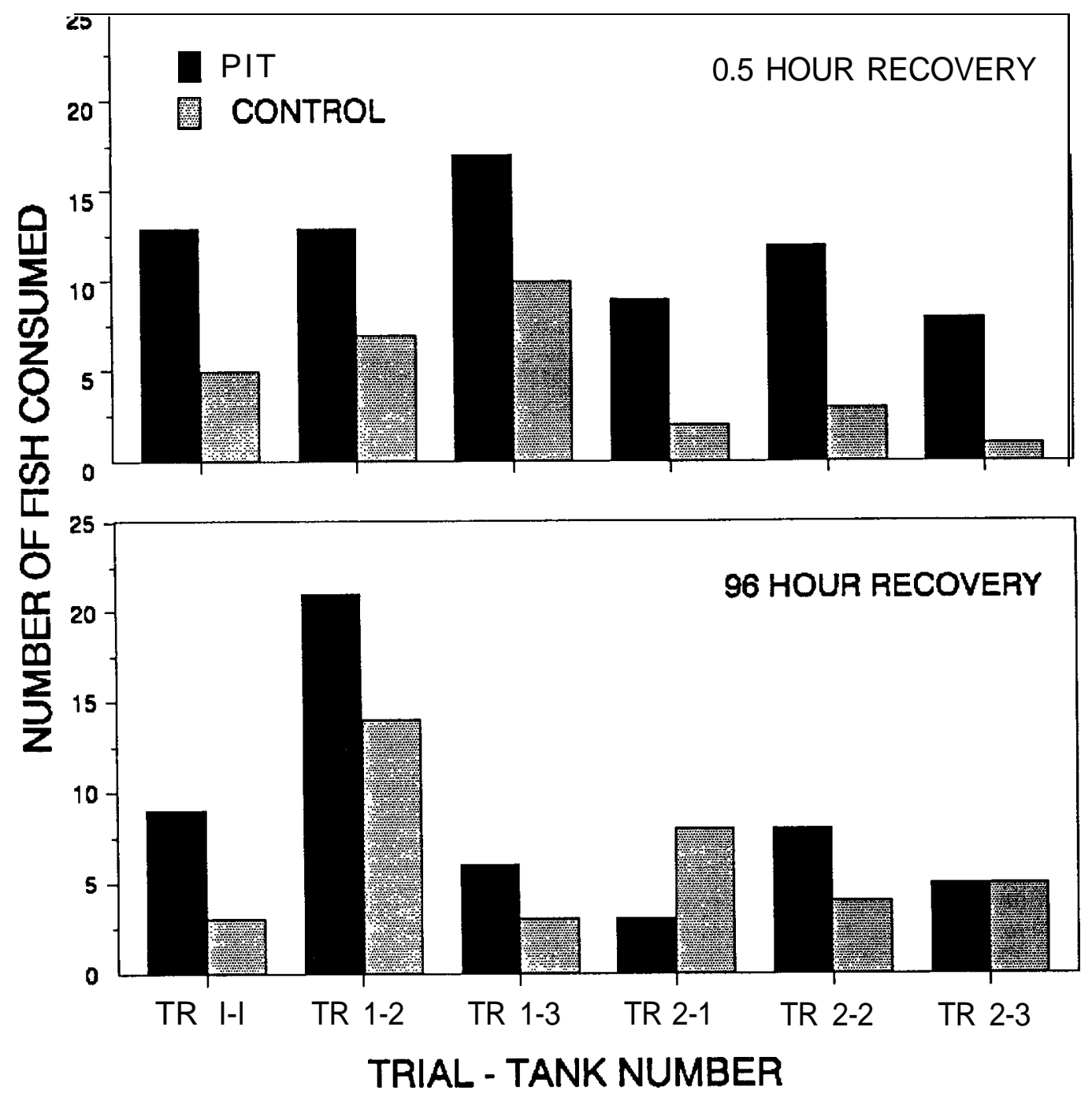

Figure 1.-Total number of juvenile chinook salmon eaten in 1991 predation vulnerability trials. Trials begun on 10 May and 17 May are shown separately as are individual tanks $(1,2$, and 3 ) in which tests were conducted. The two recovery periods, $0.5 \mathrm{~h}$ and $96 \mathrm{~h}$, are included for comparison. 
Table 1.-Results of predation risk experiments conducted in 1991 in which PIT-tagged juvenile fall chinook salmon allowed 0.5 hour recovery and controls were exposed to 24 hour predation risk by smallmouth bass.

Tag

$\begin{array}{ll}\text { Exp\#- } & \text { Number } \\ \text { tank\# } & \text { eaten }\end{array}$

$\begin{array}{ll}\text { Expected\# } & \text { Chi- } \\ \text { eaten } & \text { square }\end{array} \quad$-value

PIT

13

$1-1$

5

9.0

3.556

0.056

Control

13

PIT

$1-2$

Control

7

PIT

17

Control

$$
1-3
$$

10

PIT

$$
2-1
$$

9

Control

2

PIT

$2-2$

12

Control

PIT

$2-3$

Control

P IT

Pooled

Control

Total

8

1

72

28

5.5

4.455

0.033

13.5

1.836

0.174

2

10.0

1.800

0.176

7.5

5.400

0.016

8

1

4.5

5.440

0.019

22.469

0.0005 
Table 2.-Results of predation risk experiments conducted in 1991 in which PIT-tagged juvenile fall chinook salmon allowed 96 hour recovery and controls were exposed to 24 hour predation risk by smallmouth bass.

\begin{tabular}{|c|c|c|c|c|c|}
\hline Tag & $\begin{array}{l}\text { Exp\#- } \\
\text { tank\# }\end{array}$ & $\begin{array}{l}\text { Number } \\
\text { eaten }\end{array}$ & $\begin{array}{l}\text { Expected\# } \\
\text { eaten }\end{array}$ & $\begin{array}{l}\text { Chi- } \\
\text { square }\end{array}$ & P-value \\
\hline $\begin{array}{l}\text { PIT } \\
\text { Control }\end{array}$ & $1-1$ & $\begin{array}{l}9 \\
3\end{array}$ & 6.0 & 3.000 & 0.080 \\
\hline $\begin{array}{l}\text { PIT } \\
\text { Control }\end{array}$ & $1-2$ & $\begin{array}{l}21 \\
14\end{array}$ & 17.5 & 1.400 & 0.235 \\
\hline $\begin{array}{l}\text { PIT } \\
\text { Control }\end{array}$ & $1-3$ & $\begin{array}{l}6 \\
3\end{array}$ & 4.5 & 1.000 & 0.681 \\
\hline $\begin{array}{l}\text { PIT } \\
\text { Control }\end{array}$ & $2-1$ & $\begin{array}{l}3 \\
8\end{array}$ & 5.5 & 2.273 & 0.127 \\
\hline $\begin{array}{l}\text { PIT } \\
\text { Control }\end{array}$ & $2-2$ & $\begin{array}{l}8 \\
4\end{array}$ & 6.0 & 1.333 & 0.247 \\
\hline $\begin{array}{l}\text { PIT } \\
\text { Control }\end{array}$ & $2-3$ & $\begin{array}{l}5 \\
5\end{array}$ & 5.0 & 0.000 & 1.000 \\
\hline $\begin{array}{l}\text { PIT } \\
\text { Control }\end{array}$ & Pooled & $\begin{array}{l}52 \\
37\end{array}$ & 44.5 & 2.528 & 0.107 \\
\hline Total & & & & 9.006 & 0.1087 \\
\hline
\end{tabular}


predation tests, there were no significant trends in the relative vulnerability to predation of treatment versus control fish

(Figure 2). Predation vulnerability was not significantly different in any single tank (Tables 3, 4, and 5).

Results of the 1991 and 1992 sham-tag tests also showed no significant trend in selectivity by smallmouth bass (Figure 3). In 1991, the $0.5 \mathrm{~h}$ recovery period chi-square values comparing treatment and control fish showed no significant difference in any trial. In tank four, 16 treatment fish and 8 control fish were eaten and in tank five 8 treatment fish and 7 control fish were consumed. The heterogeneity chi-square was significant, therefore the data for the two tanks were not pooled. For the 96 $\mathrm{h}$ recovery period tests, 5 treatment and 5 control fish were eaten in tank 4, while 2 treatment fish and 4 control fish were eaten in tank 5. The heterogeneity chi-square was significant so that data was not pooled. In 1992, the $0.5 \mathrm{~h}$ recovery period comparison of sham and control showed no significant difference in four tests. The numbers of treatment to control fish eaten in four seperate tanks were 9 sham tag to 12 control; 13 sham tag to 15 control; 8 sham tag to 7 control; and 13 sham tag to 9 control. Heterogeneity chi-square was not significant so data from all four tanks were pooled. The total chi-square (0.000) was not significant $(P=1.000)$.

For 1991 experiments, a comparison of mean fork lengths of all PIT-tagged fish exposed to predation to all surviving PITtagged fish showed no significant difference between groups. Mean size of introduced PIT-tag fish was $59.9 \mathrm{~mm}$ (SD = 5.21) while mean size of survivors was $60.7 \mathrm{~mm}(\mathrm{SD}=5.28)$. A Kolmogorov-Smirnov test was used to compare the size of the PIT tagged survivors to the size of PIT-tagged fish initially stocked in predation tanks in each trial; the test showed no significant differences in their cumulative frequency distributions ( $P$ > 0.05). These results suggested there was no significant relationship between tagged fish size and vulnerability to predation.

\section{Swimming Stamina}

In both 1991 and 1992, the presence or absence of PIT tags in subyearling chinook salmon was significant in explaining the variability in swimming stamina as measured by U-critical swimming speed (ANOVA; $P<0.05$ ). For 1991 results, an interaction variable (tagging by recovery period) was also significant in the ANOVA, indicating that swim performances of treatment and control fish were affected differently depending on recovery period. Swim chamber position, experimental trial, and fork length were not significant variables in the ANOVA ( $P$ > 0.05). For 1992 results, the interaction variable (tagging by 


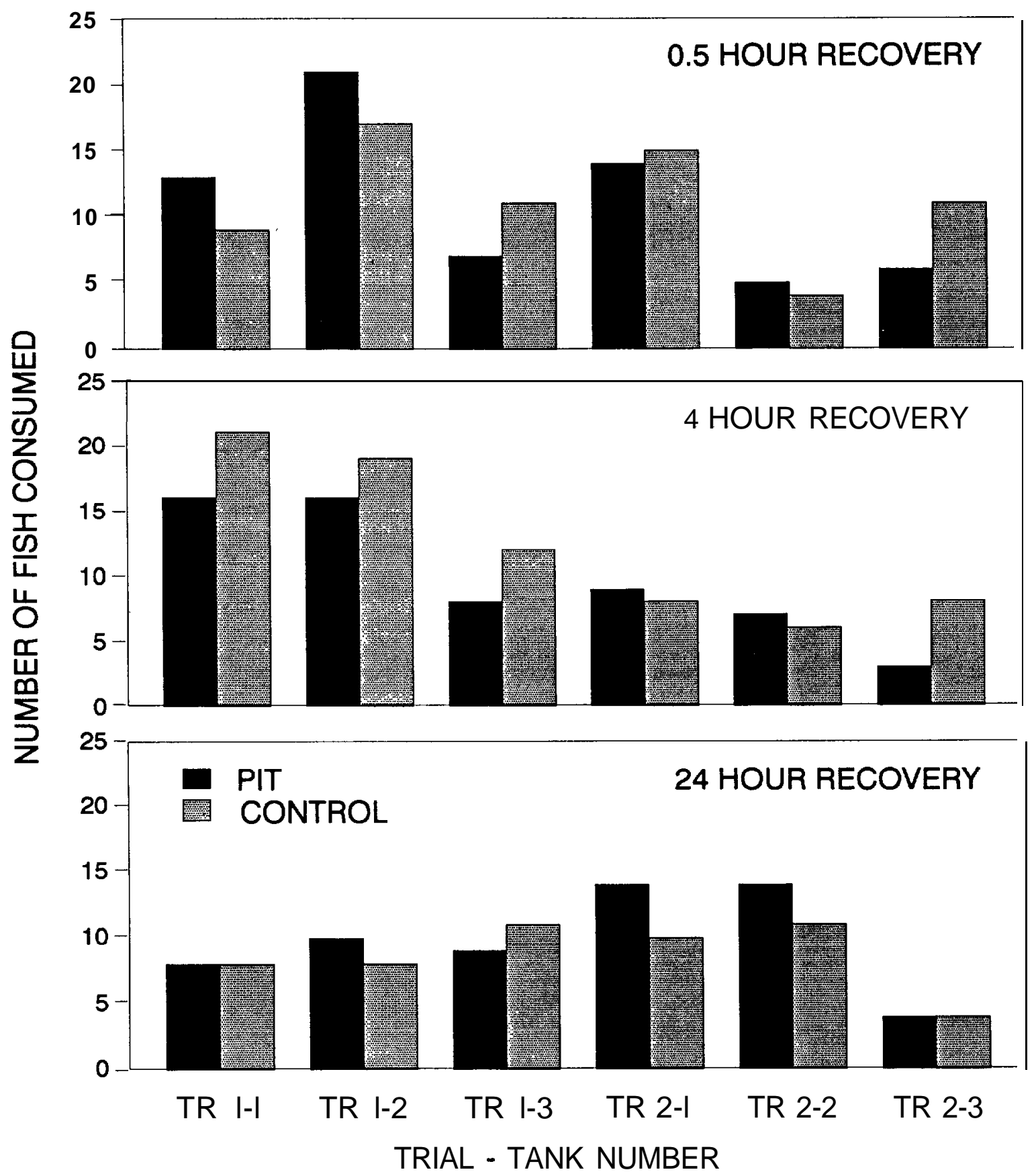

Figure 2. -Total number of juvenile chinook salmon eaten in 1992 predation vulnerability trials. Trials begun on 4 May and 11 May are shown separately as are individual tanks (1,2, and 3) in which tests were conducted. The three recovery periods, $0.5 \mathrm{~h}, 4$ $h$, and $24 \mathrm{~h}$, are included for comparison. 
Table 3.-Results of predation risk experiments conducted in 1992 in which PIT-tagged juvenile fall chinook salmon allowed 0.5 hour recovery and controls were exposed to 24 hour predation risk by smallmouth bass.

Tag $\begin{array}{llll}\text { Exp\#- } & \begin{array}{l}\text { Number } \\ \text { tank\# }\end{array} & \begin{array}{l}\text { Expected\# } \\ \text { eaten }\end{array} & \begin{array}{l}\text { Chi- } \\ \text { square }\end{array}\end{array}$

PIT 13

Control 9

$11.0 \quad 0.727 \quad 0.602$

PIT

21

Control 17

$\begin{array}{lll}19.0 & 0.421 & 0.524\end{array}$

PIT 7

Control 11

$\begin{array}{lll}9.0 & 0.889 & 0.652\end{array}$

PIT 14

Control 15

$\begin{array}{lll}14.5 & 0.034 & 0.847\end{array}$

PIT 5

Control 4
4.5
0.111
0.738

PIT

6

Control 11

$\begin{array}{lll}8.5 & 1.471 & 0.223\end{array}$

PIT

66

Control

Pooled

67

$\begin{array}{lll}66.5 & 0.008 & 0.928\end{array}$

Total

$3.653 \quad 0.603$ 
Table 4.-Results of predation risk experiments conducted in 1992 in which PIT tagged juvenile fall chinook salmon allowed 4 hour recovery and controls were exposed to 24 hour predation risk by smallmouth bass.

Tag

$$
\text { Exp\#- Number }
$$

tank\#

eaten

Expected\# Chi-

P-value

eaten

square

PIT

16

1-1

18.5

0.676

0.583

Control

21

PIT

16

Control

$1-2$

19

PIT

$1-3$

8

Control

12

PIT

Control

2-1

8.5

0.059

0.802

PIT

Control

2-2

6.5

0.077

0.778

PIT

$2-3$

3

Control

8

5.5

2.273

0.128

PIT

59

Control

Pooled

74

66.5

1.692

0.190

Total

4.141

0.531 
Table S.-Results of predation risk experiments conducted in 1992 in which PIT tagged juvenile fall chinook salmon allowed 24 hour recovery and controls were exposed to 24 hour predation risk by smallmouth bass.

Tag

$\begin{array}{ll}\text { Exp\#- } & \text { Number } \\ \text { tank\# } & \text { eaten }\end{array}$

Expected\# eaten

P-value tank\#

$$
8
$$

P IT

$$
1-1
$$

8

8.0

0.000

1.000

Control

10

PIT

$$
1-2
$$

Control

PIT

$$
1-3
$$

Control

PIT

$$
\text { 2-1 }
$$

Control

PIT

$$
2-2
$$

Control

11

PIT

$$
2-3
$$

Control

PIT

Pooled

Control

59

Total

Chi-

square
11

14

10

14

\section{4}

4

52

9

1

4

10

12.0

0.667

0.580

10.0

0.200

0.659

0.222

0.643

1

12.5

0.360

0.556

4

4.0

0.000

1.000
55.5

0.441

0.514

1. 449

0.918 


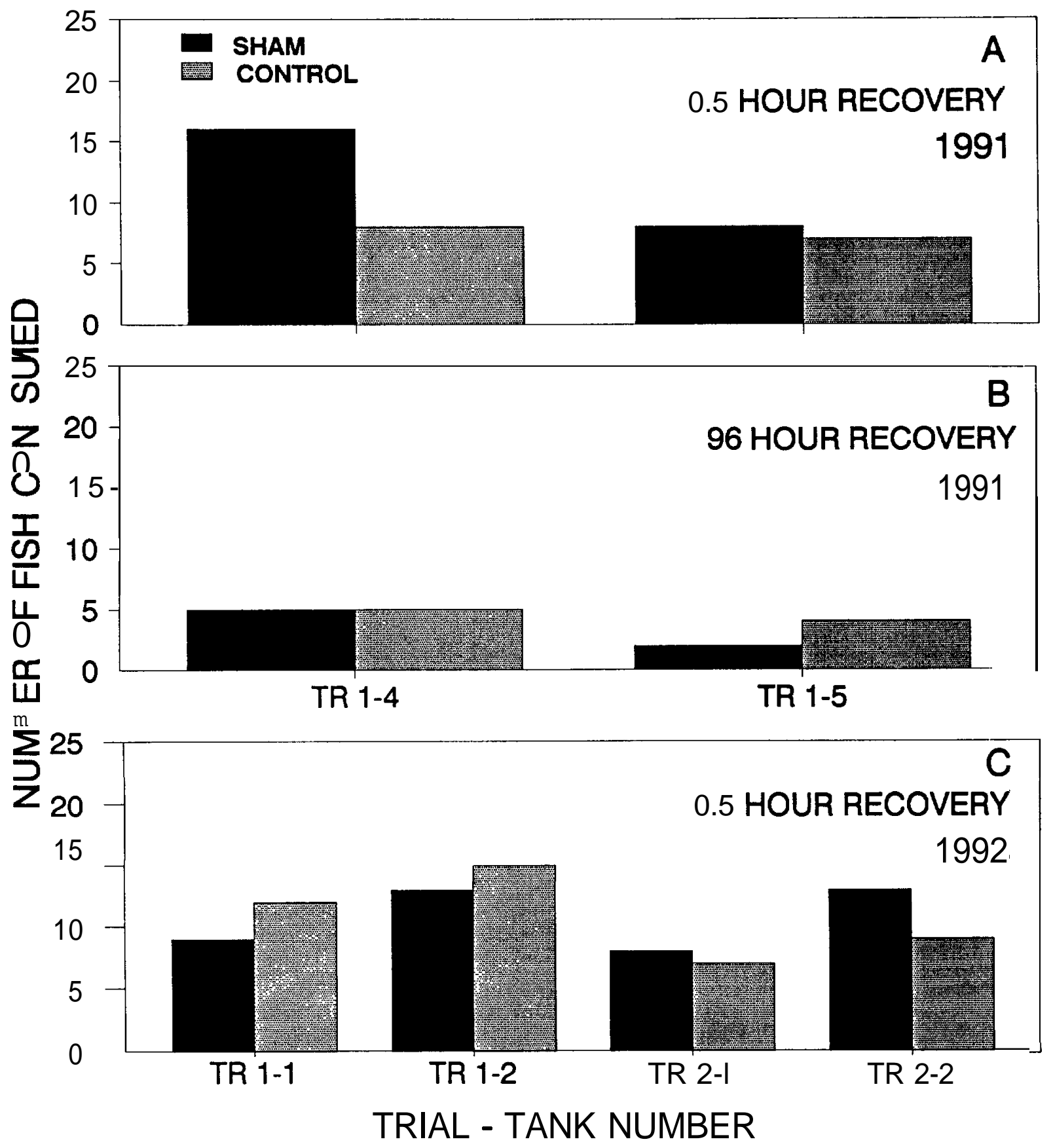

Figure 3.-Total number of juvenile chinook salmon eaten in predation vulnerability experiments in which treatment fish were sham tagged. Two 1991 recovery periods, $0.5 \mathrm{~h}$ (A) and $96 \mathrm{~h}$ (B) are shown for comparison. Graph C shows 1992 results of $0.5 \mathrm{~h}$ recovery trials. 
recovery period) was not significant indicating they recovered in a similar manner.

In 1991, fish tested after a $0.5 \mathrm{~h}$ recovery period had significantly lower swimming stamina than those allowed $4 \mathrm{~h}$ or more recovery time when compared using Tukey's test of means (Table 6 and 7). The 1991 results show the U-criticals of treatment fish were lower than controls when allowed $0.5 \mathrm{~h}$ recovery, but comparable with controls when tagged fish were allowed four or more hours recovery (Figure 4). In 1992 swimming stamina tests, treatment fish had significantly lower mean swimming stamina than control fish according to Tukey's comparison of means (Table 8). All tag groups performed more poorly than controls during 1992 tests (Figure 5).

\section{Tag Retention and Delayed Mortality}

Tag retention for all groups of PIT-tagged fish was greater than 97\% in 1991 tests (Table 9). In the first trial of the 1991 experiment, begun on $10 \mathrm{May}$, overall tag retention was 97\%, while in the second trial, begun May 17 tag, retention improved to over 99\%. Mortality for all groups of treatment fish, including those held for $96 \mathrm{~h}$ predation trials, was 20\% compared to no mortality for control groups. In those tanks where treatment fish were held for tag retention and mortality tests, mortality ranged from 7\% to 27\% of the fish stocked in each tank compared to no mortalities in the control groups (Table 10).

\section{Longterm Growth}

During the 1992 longterm growth experiments, only the middle size group showed a significant difference in mean length at any time (Table 11). While lengths and weights were taken on 28 July the data was not useful because control fish were no longer distinguishable from treatment fish that might have lost their tags. In fact counts showed over 100 control fish in both the middle, and large size groups on July 28. Treatment fish that had lost tags were being identified as control fish because their tag insertion scars were no longer visible. Through 25 June mortality of control fish was 6\% while treatment fish mortality was 7\% (20 control and 21 treatment mortalities were counted that date).

\section{Discussion}

The effects of tagging on subyearling fall chinook salmon behavior were substantial, but appeared to be short term. In 1991, predation on tagged fish by smallmouth bass in the predation vulnerability tests indicated that $96 \mathrm{~h}$ recovery provided considerable benefits over just $0.5 \mathrm{~h}$ recovery times. 
Table 6.-1991 swimming stamina comparison tests between PIT tagged and control subyearling chinook salmon. Mean $U_{\text {critical }}{ }^{a}$, lengths and standard deviations are listed for each group of six PIT tagged and six control fish swum simultaneously in a divided swim chamber.

\begin{tabular}{|c|c|c|c|c|c|c|c|c|}
\hline \multirow[b]{2}{*}{$\begin{array}{l}\text { Recovery } \\
\text { Period }\end{array}$} & \multicolumn{4}{|c|}{ PIT Tag } & \multicolumn{4}{|c|}{ Control } \\
\hline & \multicolumn{2}{|c|}{$\begin{array}{l}\text { Mean } F L \\
(s t d)\end{array}$} & \multicolumn{2}{|c|}{$\begin{array}{c}\text { Mean Ucrit. } \\
\text { (std) }\end{array}$} & \multicolumn{2}{|c|}{$\begin{array}{c}\text { Mean FL } \\
\text { (std) }\end{array}$} & \multicolumn{2}{|c|}{$\begin{array}{l}\text { Mean Ucrit. } \\
\text { (std) }\end{array}$} \\
\hline $\begin{array}{c}\text { Replicate } 1 \\
0.5 \text { hours }\end{array}$ & 58.0 & $(1.00)$ & 3.09 & $(1.87)$ & $57 \quad 5$ & $(1,26)$ & 5.99 & $(0.82)$ \\
\hline 0.5 hours & 57.7 & $(1.11)$ & 3.76 & $(2.38)$ & 57.8 & $(1.34)$ & 6.69 & $(1.13)$ \\
\hline 24 hours & 57.2 & $(1.34)$ & 8.60 & $(2.26)$ & 56.3 & $(2.69)$ & 7.87 & $(2.09)$ \\
\hline 24 hours & 56.3 & $(2.05)$ & 6.60 & $(1.73)$ & 57.8 & $(2.67)$ & 7.49 & $(0.92)$ \\
\hline 96 hours & 58.0 & $(1.41)$ & 7.70 & $(1.79)$ & 56.3 & $(1.80)$ & 7.92 & $(1.05)$ \\
\hline 96 hours & 59.5 & $(0.50)$ & 8.26 & $(1.37)$ & 56.2 & $(1.68)$ & 8.10 & $(1.09)$ \\
\hline $\begin{array}{c}\text { Replicate } 2 \\
0.5 \text { hours }\end{array}$ & 58.2 & $(1.77)$ & 6.47 & $(2.00)$ & 60.2 & $(1.57)$ & 7.16 & $(1.02)$ \\
\hline 0.5 hours & 58.5 & $(1.89)$ & 5.00 & $(2.89)$ & 57.0 & $(1.41)$ & 7.36 & $(1.05)$ \\
\hline 4 hours & 59.7 & $(1.60)$ & 7.07 & $(0.88)$ & 54.7 & $(2.13)$ & 7.11 & $(0.64)$ \\
\hline 4 hours & 57.5 & $(2.99)$ & 7.16 & $(2.54)$ & 59.8 & $(2.03)$ & 7.41 & $(1.42)$ \\
\hline 48 hours & 55.7 & $(1.60)$ & 6.88 & $(1.45)$ & 56.0 & $(4.47)$ & 6.60 & $(1.43)$ \\
\hline 48 hours & 56.8 & $(3.44)$ & 7.14 & $(1.70)$ & 57.3 & $(1.49)$ & 7.46 & $(0.83)$ \\
\hline 96 hours & 55.5 & $(0.96)$ & 7.50 & $(0.54)$ & 53.0 & $(3.42)$ & 6.89 & $(0.87)$ \\
\hline 96 hours & 58.3 & $(1.80)$ & 7.60 & $(0.35)$ & 55.8 & $(3.67)$ & 7.53 & $(0.57)$ \\
\hline
\end{tabular}

a $U_{\text {critical }}$ were determined by swimming fish in a flume with a beginning velocity of 1.5 body lengths per second ( $1 \mathrm{BdL}=60 \mathrm{~mm}$ ) and increasing the velocity 0.5 body lengths every 15 minutes. $\mathrm{U}_{\text {critical }}$ express the highest 15 minute velocity increment (BdL/sec) the fish swam at plus the proportion of the last increment during which the fish was exhausted. 
Table 7.-1992 Swimming stamina comparison tests between PIT tagged and control subyearling chinook salmon. Mean $\mathrm{U}_{\text {critical }}{ }^{a}$, lengths and standard deviations are listed for each group of six PIT tagged and six control fish swum simultaneously in a divided swim chamber.

\begin{tabular}{llcccc}
\hline & \multicolumn{2}{c}{ PIT Tag } & & \multicolumn{2}{c}{ Control } \\
\cline { 2 - 3 } \cline { 5 - 6 } $\begin{array}{l}\text { Recovery } \\
\text { Period }\end{array}$ & $\begin{array}{c}\text { Mean FL } \\
\text { ( s t d ) }\end{array}$ & $\begin{array}{c}\text { Mean Ucrit. } \\
\text { (std) }\end{array}$ & & $\begin{array}{c}\text { Mean FL } \\
\text { (std) }\end{array}$ & $\begin{array}{c}\text { Mean Ucrit. } \\
\text { (std) }\end{array}$ \\
\hline
\end{tabular}

\begin{tabular}{|c|c|c|c|c|c|c|c|c|c|}
\hline \multicolumn{10}{|c|}{ Replicate 1} \\
\hline 0.5 & hours & 64.2 & $(1.95)$ & 5.70 & $(0.37)$ & 59.8 & $(2.19)$ & 5.58 & $(0.80)$ \\
\hline 0.5 & hours & 63.8 & $(3.34)$ & 5.16 & $(0.61)$ & 63.8 & $(2.79)$ & 5.44 & $(0.21)$ \\
\hline 4 & hours & 61.3 & $(2.49)$ & 5.53 & $(0.35)$ & 62.2 & $(1.86)$ & 5.72 & $(0.36)$ \\
\hline 4 & hours & 62.7 & $(2.56)$ & 4.89 & $(1.17)$ & 61.7 & $(3.25)$ & 5.36 & $(0.32)$ \\
\hline 24 & hours & 62.7 & $(3.40)$ & 5.59 & $(0.76)$ & 63.3 & $(3.25)$ & 5.78 & $(0.71)$ \\
\hline 24 & hours & 62.0 & $(3.31)$ & 4.83 & $(1.04)$ & 62.2 & $(4.63)$ & 5.46 & $(0.49)$ \\
\hline Repl: & cate & & & & & & & & \\
\hline 0.5 & hours & 66.3 & $(3.49)$ & 5.13 & $(1.09)$ & 66.0 & $(1.91)$ & 5.33 & $(0.51)$ \\
\hline 0.5 & hours & 65.5 & $(2.14)$ & 5.23 & $(0.42)$ & 67.3 & $(3.40)$ & 5.79 & $(0.58)$ \\
\hline 4 & hours & 63.2 & $(2.11)$ & 5.13 & $(0.75)$ & 65.5 & $(4.31)$ & 5.52 & $(0.40)$ \\
\hline 4 & hours & 65.7 & $(1.97)$ & 4.26 & $(1.04)$ & 63.7 & $(3.20)$ & 3.19 & $(2.36)$ \\
\hline 24 & hours & 63.8 & $(2.11)$ & 5.30 & $(1.05)$ & 67.7 & $(3.73)$ & 6.24 & $(0.80)$ \\
\hline 24 & hours & 64.7 & $(4.82)$ & 5.26 & $(1.33)$ & 64.3 & $(1.60)$ & 5.24 & $(1.10)$ \\
\hline
\end{tabular}

a $U_{\text {critical }}$ were determined by swimming fish in a flume with a beginning velocity of 1.5 body lengths per second ( $1 \mathrm{BdL}=60 \mathrm{~mm}$ ) and increasing the velocity 0.5 body lengths every 15 minutes. $U_{\text {critical }}$ express the highest 15 minute velocity increment (BdL/sec) the fish swam at plus the proportion of the last increment during which the fish was exhausted. 

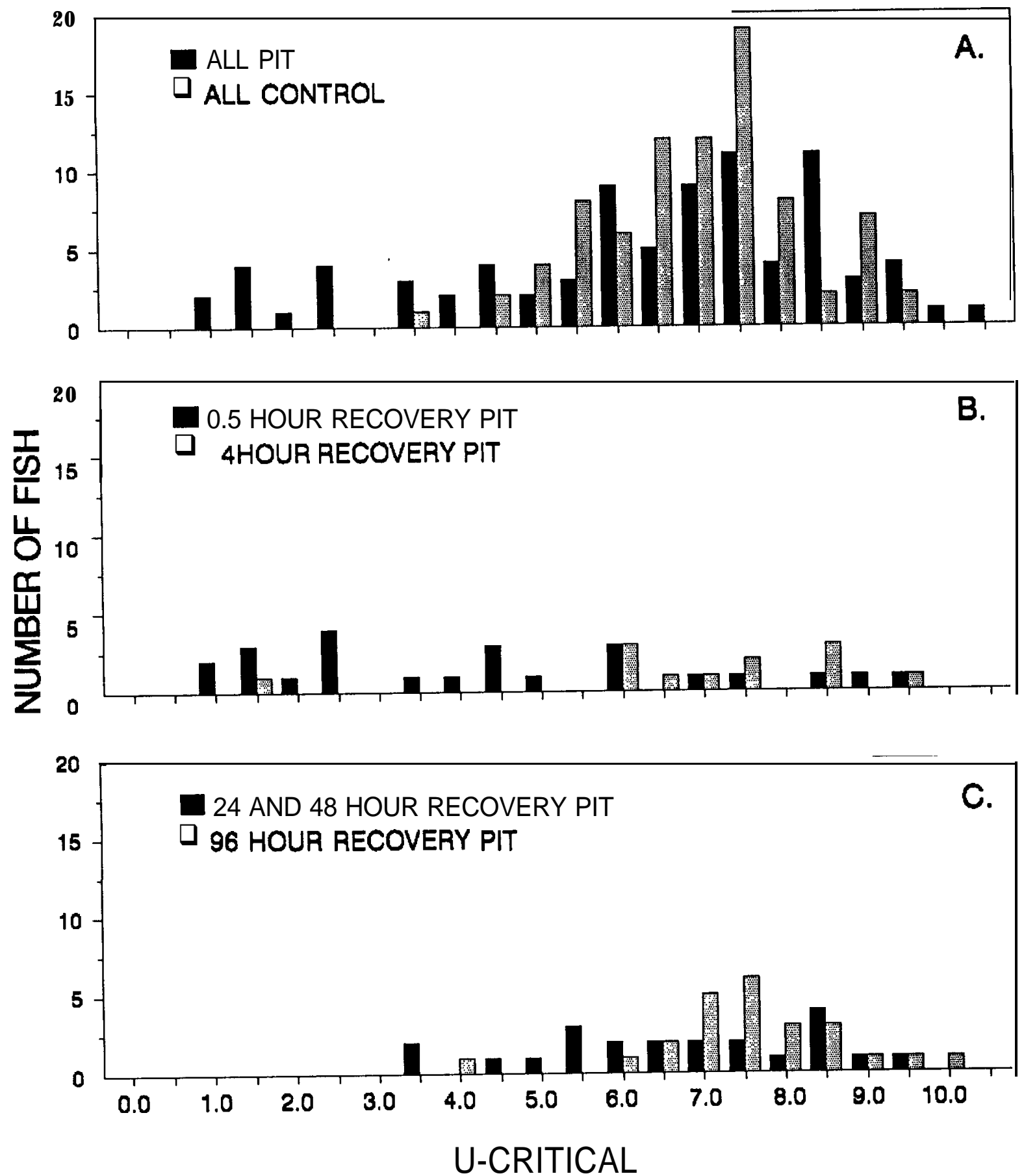

Figure 4.-Frequency histograms of U-critical values for all fish tested. A. All PIT-tagged and all control fish. B. PITtagged fish with $0.5 \mathrm{~h}$ and $4 \mathrm{~h}$ recovery periods. C. PIT-tagged fish with $24 \mathrm{~h}, 48 \mathrm{~h}$, and $96 \mathrm{~h}$ recovery periods. 
Table 8.-Tukey's studentized range (HSD) test of mean Ucriticals for each recovery period for all fish (PIT tag and controls) . Alpha $=0.05$ Confidence $=0.95 \mathrm{df}=158 \mathrm{MSE}=$ 2.890148. Critical Value of Studentized Range $=3.903$. Comparisons significant at the 0.05 level are indicated by '***'.

\begin{tabular}{|c|c|c|c|c|c|}
\hline $\mathrm{Co}$ & $\begin{array}{l}\text { cov } \\
\text { parison }\end{array}$ & $\begin{array}{c}\text { Simultaneous } \\
\text { Lower } \\
\text { Confidence } \\
\text { Limit }\end{array}$ & $\begin{array}{c}\text { Difference } \\
\text { Between } \\
\text { Means }\end{array}$ & $\begin{array}{c}\text { Simultaneous } \\
\text { Upper } \\
\text { Confidence } \\
\text { Limit }\end{array}$ & \\
\hline $\begin{array}{l}96 \\
96 \\
96 \\
96\end{array}$ & $\begin{array}{l}-24 \\
-4 \\
-48 \\
-0.5\end{array}$ & $\begin{array}{r}-1.127 \\
-0.736 \\
-0.506 \\
1.006\end{array}$ & $\begin{array}{l}0.045 \\
0.437 \\
0.666 \\
1.964\end{array}$ & $\begin{array}{l}1.218 \\
1.610 \\
1.839 \\
2.921\end{array}$ & $\star \star \star \star *$ \\
\hline $\begin{array}{l}24 \\
24 \\
24 \\
24\end{array}$ & $\begin{array}{l}-96 \\
-4 \\
-48 \\
-0.5\end{array}$ & $\begin{array}{r}-1.218 \\
-0.963 \\
-0.733 \\
0.746\end{array}$ & $\begin{array}{r}-0.045 \\
0.391 \\
0.621 \\
1.918\end{array}$ & $\begin{array}{l}1.127 \\
1.746 \\
1.975 \\
3.091\end{array}$ & $\star \star \star$ \\
\hline $\begin{array}{l}4 \\
4 \\
4 \\
4\end{array}$ & $\begin{array}{l}-96 \\
-24 \\
-48 \\
-0.5\end{array}$ & $\begin{array}{r}-1.610 \\
-1.746 \\
-1.125 \\
0.354\end{array}$ & $\begin{array}{r}-0.437 \\
-0.391 \\
0.230 \\
1.527\end{array}$ & $\begin{array}{l}0.736 \\
0.963 \\
1.584 \\
2.700\end{array}$ & 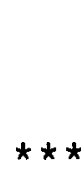 \\
\hline $\begin{array}{l}48 \\
48 \\
48 \\
48\end{array}$ & $\begin{array}{l}-96 \\
-24 \\
-4 \\
-0.5\end{array}$ & $\begin{array}{r}-1.839 \\
-1.975 \\
-1.584 \\
0.125\end{array}$ & $\begin{array}{r}-0.666 \\
-0.621 \\
-0.230 \\
1.297\end{array}$ & $\begin{array}{l}0.506 \\
0.733 \\
1.125 \\
2.470\end{array}$ & $\star \star \star$ \\
\hline $\begin{array}{l}0.5 \\
0.5 \\
0.5 \\
0.5\end{array}$ & $\begin{array}{l}-96 \\
-24 \\
-4 \\
-48\end{array}$ & $\begin{array}{l}-2.921 \\
-3.091 \\
-2.700 \\
-2.470\end{array}$ & $\begin{array}{l}-1.964 \\
-1.918 \\
-1.527 \\
-1.297\end{array}$ & $\begin{array}{l}-1.006 \\
-0.746 \\
-0.354 \\
-0.125\end{array}$ & $\begin{array}{l}\star \star \star \\
\star \star \star \\
\star \star \star \\
\star \star \star\end{array}$ \\
\hline
\end{tabular}




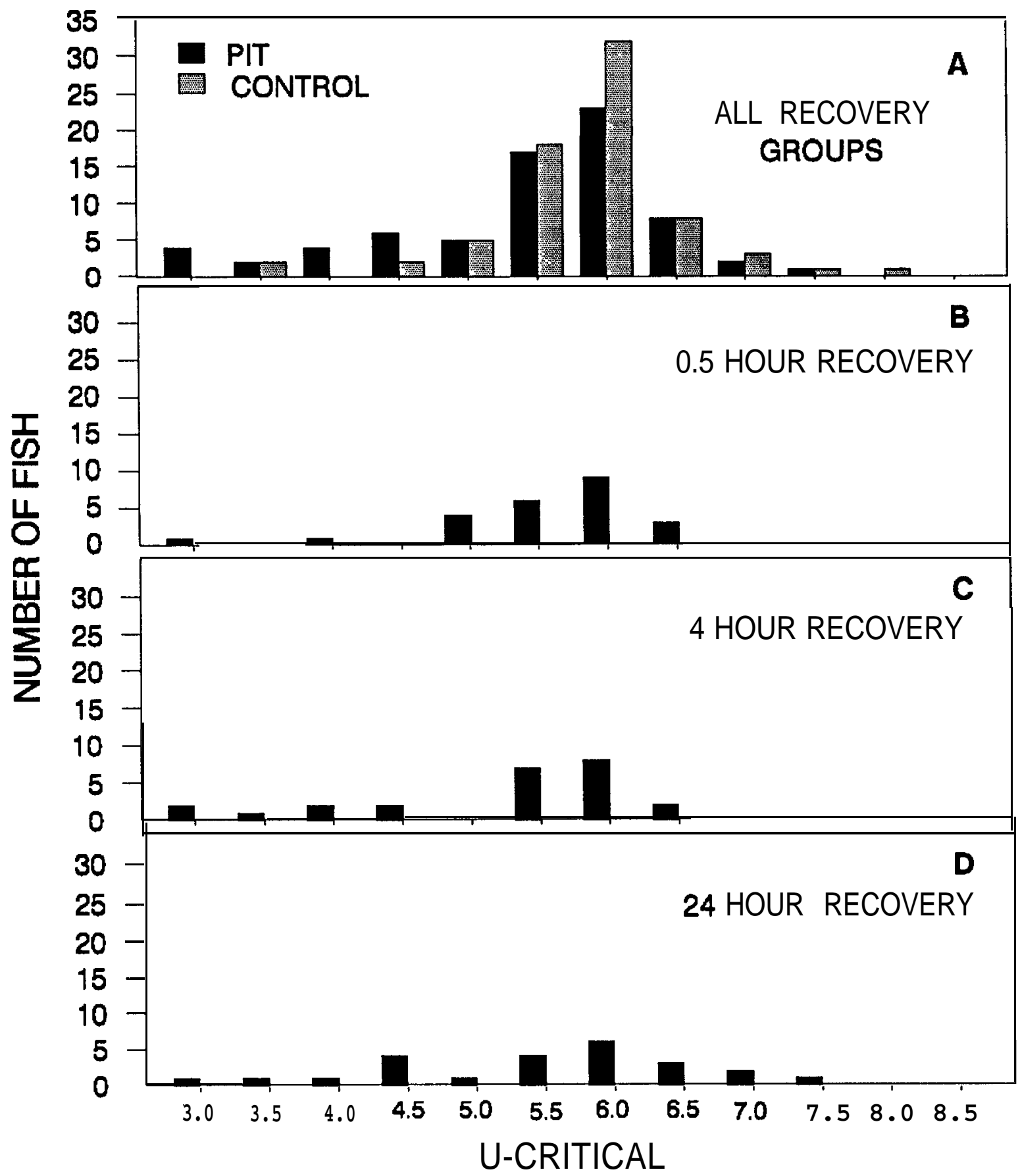

Figure 5. Frequency histograms of U-critical values for all fish tested. A. All PIT-tagged and all control fish. B. PITtagged fish with $0.5 \mathrm{~h}$ recovery period. C. PIT-tagged fish eith 4 $h$ recovery period. D. PIT-tagged fish with $24 \mathrm{~h}$ recovery period. 
Table 9.-Delayed mortality of subyearling fall chinook salmon PIT tagged (on 10 May 1991--experiment one and 17 May 1991-experiment two) and held in tanks compared to mortality in subyearlings neither tagged nor anesthetized (control). Forty fish were held in each tank.

Mortalities and percent mortality

Hours after tagging PIT tag control PIT tag control

24

$\begin{array}{llllllllll}\text { Rep. } & 1 & 10 & (25 \%) & 0 & (0 \%) & 7 & (17 \%) & 0 & (0 \%) \\ \text { Rep. } & 2 & 11 & (27 \%) & 0 & (0 \%) & 3 & (7 \%) & 0 & (0 \%) \\ \text { Rep. } & 1 & 1 & (27 \%) & 0 & & & 0 & & \\ \text { Rep. } 2 & 0 & & 0 & & 0 & & 0\end{array}$

72

Rep. 1

Rep. 2

$\begin{array}{ll}0 & 0 \\ 0 & 0\end{array}$

$\begin{array}{ll}0 & 0 \\ 0 & 0\end{array}$

96

Rep. 1

Rep. 2

$\begin{array}{ll}0 & 0 \\ 0 & 0\end{array}$

$\begin{array}{ll}0 & 0 \\ 0 & 0\end{array}$

Cumulative Mortality

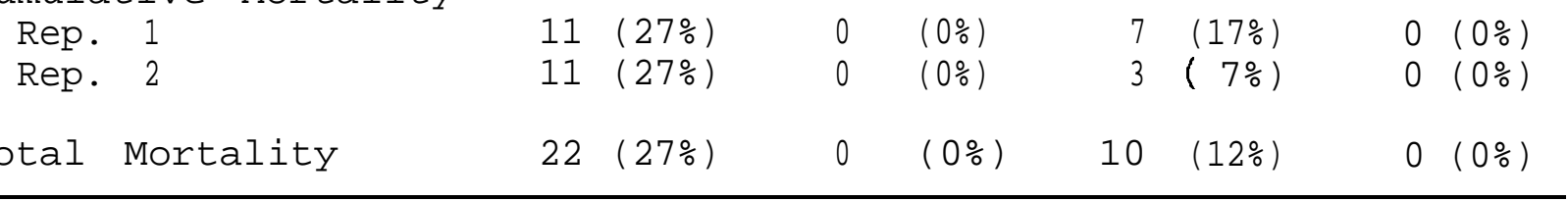


Table 10.-Percent of PIT tags retained up to 96 hours by subyearling chinook salmon tagged on 10 May 1991.

\begin{tabular}{|c|c|c|c|}
\hline \multirow{2}{*}{ Group } & \multirow{2}{*}{$\begin{array}{l}\text { Number of fish } \\
\text { PIT tagged }\end{array}$} & \multicolumn{2}{|c|}{ Tag retention } \\
\hline & & Number & Percent \\
\hline \multicolumn{4}{|c|}{ Delayed Mortality } \\
\hline Rep. 1 & 81 & 77 & 95 \\
\hline Rep. 2 & 81 & 80 & 99 \\
\hline \multicolumn{4}{|l|}{ Swim Test } \\
\hline Rep. 1 & 59 & 57 & 97 \\
\hline Rep. 2 & 64 & 64 & 100 \\
\hline \multicolumn{4}{|c|}{$\begin{array}{l}\text { Predation } \\
\text { by recovery period } \\
(0.5 \text { hour })\end{array}$} \\
\hline Rep. 1 & 53 & 51 & 96 \\
\hline Rep. 2 & 64 & 64 & 100 \\
\hline \multicolumn{4}{|l|}{ (96 hour) } \\
\hline Rep. 1 & 60 & 60 & 100 \\
\hline Rep. 2 & 80 & 79 & 99 \\
\hline \multicolumn{4}{|l|}{514} \\
\hline Rep. 1 & 10 & 10 & 100 \\
\hline Rep. 2 & 15 & 15 & 100 \\
\hline \multicolumn{4}{|c|}{ Cumulative } \\
\hline Rep. 1 & 263 & 255 & 97 \\
\hline Rep. 2 & 304 & 302 & 99 \\
\hline
\end{tabular}


Table Il.-Results of longterm growth tests in which treatment and control fish were held in tanks and periodically weighed and measured.

\begin{tabular}{|c|c|c|c|c|c|c|}
\hline Tank & Date & Tag Group & Mean FL & Pooled STD & $t$ & t-Table \\
\hline \multirow[t]{8}{*}{ A } & $5 / 13$ & CONTROL & 55.6 & 2.42 & 1.92 & 1.97 \\
\hline & $5 / 13$ & TREATMENT & 56.2 & & & \\
\hline & $6 / 04$ & CONTROL & 62.0 & 3.42 & 1.78 & 1.98 \\
\hline & $6 / 04$ & TREATMENT & 60.8 & & & \\
\hline & $6 / 25$ & CONTROL & 72.8 & 4.62 & 0.92 & 0.98 \\
\hline & $6 / 25$ & TREATMENT & 73.4 & & & \\
\hline & $7 / 28$ & CONTROL & 83.9 & --- & --- & --- \\
\hline & $7 / 28$ & TREATMENT & 84.4 & & & \\
\hline \multirow[t]{8}{*}{ B } & $5 / 13$ & CONTROL & 64.7 & 2.59 & 1.02 & 1.97 \\
\hline & $5 / 13$ & TREATMENT & 64.4 & & & \\
\hline & $6 / 04$ & CONTROL & 69.6 & 3.27 & $2.41 \star$ & 1.98 \\
\hline & $6 / 04$ & TREATMENT & 68.0 & & & \\
\hline & $6 / 25$ & CONTROL & 83.4 & 4.62 & 1.49 & 1.98 \\
\hline & $6 / 25$ & TREATMENT & 82.0 & & & \\
\hline & $7 / 28$ & CONTROL & 95.7 & --- & --- & --- \\
\hline & $7 / 28$ & TREATMENT & 93.5 & & & \\
\hline \multirow[t]{8}{*}{$\mathrm{C}$} & $5 / 13$ & CONTROL & 71.5 & 1.60 & 0.0 & 1.97 \\
\hline & $5 / 13$ & TREATMENT & 71.5 & & & \\
\hline & $6 / 04$ & CONTROL & 78.7 & 3.04 & 0.69 & 1.98 \\
\hline & $6 / 04$ & TREATMENT & 79.2 & & & \\
\hline & $6 / 25$ & CONTROL & 90.2 & 4.59 & 1.04 & 1.98 \\
\hline & $6 / 25$ & TREATMENT & 91.1 & & & \\
\hline & $7 / 28$ & CONTROL & 101.2 & --- & $-\cdots$ & --- \\
\hline & $7 / 28$ & TREATMENT & 102.4 & & & \\
\hline
\end{tabular}

Those means marked with an asterisk (*) are those that are significantly different according to the Student's $t$ (alpha $=$ $0.05)$.

t-tests were not reported for data recorded on 7/28 because treatment fish that had lost tags could no longer be distinguished from control fish due to healing of tag insertion scars. 
Inasmuch as mortality was relatively high among tagged groups during the first $24 \mathrm{~h}$ after tagging those individuals selected by smallmouth bass may have been in similar condition to individuals that died in the delayed mortality tests. By contrast, in 1992, predation vulnerability of treatment fish was not different compared to controls in $0.5 \mathrm{~h}, 4 \mathrm{~h}$, and $24 \mathrm{~h}$ groups. This difference in results was likely related to improved tagging techniques which greatly reduced mortality in tagged fish. The size of the tagged fish might also have contributed this difference because in 1491, fish as small as $48 \mathrm{~mm}$ were tagged while in 1992, no fish were tagged under $60 \mathrm{~mm}$.

During 1991 trials, PIT tagging significantly lowered the swim performance of fish allowed only $0.5 \mathrm{~h}$ to recover from tagging. Treatment fish allowed four or more hours to recover performed as well as control fish in swim performance tests. In 1992 all treatment-recovery groups had lower swim stamina than controls.

PIT tagging caused high mortality in 1991 experiments. Prentice et al. (1986) found mortality rate (4\%) did not increase significantly in fish as small as $64 \mathrm{~mm}$ average fork length. In 1992 longterm growth trials, the mortality rate attributable to PIT tagging was less than 1 percent. The high mortality rate we observed in 1991 trials, 20\% overall, might have been due to the relatively small size of the fish tagged, administration of the anesthetic, tagging technique, and the inexperience with tagging small fish.

A significant change in tagging technique, in 1992, was the use of a buffered anesthetic. Other investigators have found that buffered anesthetic can result in reduced mortality when using soft water (Wedemeyer 1970; Soivio et al. 1977; Sylvester and Holland 1982). The combination of anesthetizing too many fish at one time and the relatively slow rate of PIT tagging with a syringe might also have caused high mortality in earlier experiments. Furthermore, in the field where the average catch rate was 2.1 fish per seine haul, the small number of fish made the anesthetizing and handling relatively quick despite working from a boat.

Initially we assumed that our inexperience with tagging relatively small fish may have attributed to the high post tagging mortality. However, training tests with an inexperienced person contradict that assumption since a 4\% mortality rate was observed. The tagging technique is very important for relatively small fish. Prentice et al. (1990b) indicated that once the needle passes through the body wall musculaturer, the needle angle is changed and then inserted farther until its point is posterior to the pyloric caecae near the pelvic girdle. However, we found that after the needle passes through the body wall, it 
can be backed out and the tag inserted into the body cavity resulting in less internal intrusion and higher tag retention.

The validity of migration timing data of the Snake River fall chinook salmon relies on whether or not tagged fish behave in a manner similar to the untagged fish. This question can only be partially answered by laboratory experiments. Knowing the effects of tagging on swim performance and predation vulnerability is not equivalent to knowing the effects of tagging on such specialized beha'vior as migration timing. However, these tests do indicate that some behavior (such as predator avoidance) may not be affected if fish are allowed an adequate recovery period.

\section{Conclusions}

1. In 1992 experiments, delayed mortality of PIT-tagged fish ranged from 7\% to 27\% and occurred primarily in the first $24 \mathrm{~h}$ after tagging. During long-term growth experiments conducted in 1992, with a rearing period of 44 d, mortality rate attributable to PIT tagging was $1 \%$.

2. Factors that we believe contributed to the lower mortality of subyearling chinook salmon in 1992 versus 1991 were improved tag insertion technique, the larger size of experimental fish in 1992, and, most importantly, the application of anesthetic. Use of buffered anesthetic and shorter total exposure times to anesthetic may be critical factors in reducing mortality.

3. The reduction of predation vulnerability of $0.5 \mathrm{~h}$ treatment recovery groups from 1991 to 1992 may have been related to reduced mortality rate and therefore related to those factors listed in conclusion 2 .

4. Predation of PIT-tagged fish was not size selective based on the comparison of the size PIT-tagged fish stocked into predation tanks versus the size of fish surviving the tests.

5. A comparison of U-critical swimming speed of PIT-tagged and control fish allowed to recover for time periods ranging from 0.5 $\mathrm{h}$ to $96 \mathrm{~h}$ indicated that effects from tagging on swimming performance could be as long as $24 \mathrm{~h}$. Furthermore, stresses related to PIT tagging appear to affect swim stamina differently than mortality rate and predation vulnerability. 


\section{References}

Beamish, F.W.H. 1978. Swimming Capacity, pages 101-187 in W.S. Hoar, and D.J. Randall, editors. Fish Physiology, Volume VII, Locomotion, Academic Press Inc., New York.

Blazka, P., M. Volf, and M. Cepela. 1960. A new type respirometer for the determination of the metabolism of fish in an active state. Physiologia Bohemoslovenica $9: 553-558$.

Connor, W.P., R.H. Burge, and W.H. Miller. 1993. Migratory behavior of subyearling chinook salmon from the freeflowing Snake River to Lower Granite Dam. in D.W. Rondorf and W.H. Miller, editors. Identification of the spawning rearing, and migratory requirements of fall chinook salmon in the Columbia River Basin. Report (contract DE-AI79-91BP21708, project 91-29) to Bonneville Power Administration, Portland, Oregon.

Prentice, E.F., T.A. Flagg, and C.S. McCutcheon. 1990a. Feasibility -of using implantable passive integrated Transponder (PIT) tags in salmonids. American Fisheries Society Symposium 7:317-322.

Prentice, E.F., T.A. Flagg, C.S. McCutcheon, D.F. Brastow, and D.C. Cross. 1990b. Equipment, methods, and an automated data-entry station for PIT tagging. American Fisheries Society Symposium 7:335-340.

Prentice, Earl F., D.L. Park, T.A. Flagg, and S. McCutcheon. 1986. A study to determine the biological feasibility of a new fish tagging system. Report (Contract DE-AI79-84BP11982, Project 83-319) to Bonneville Power Administration, Portland, Oregon.

SAS Institute Inc. 1988. SAS/STAT User's Guide, Release 6.03 Edition. SAS Institute Inc., Cary, North Carolina.

Sokal, R.R., and F.J. Rohlf. 1981. Biometry, Second Edition. W.H. Freeman and Company, New York.

Soivio, A., K. Nyholm, and M. Huhti. 1977. Effects of anaesthesia with MS 222, neutralized MS 222 and benzocaine on the blood constituents of rainbow trout, Salmogairdneri. Journal of Fish Biology 10:91-101.

Sylvester, J.R., and L.E. Holland. 1982. Influence of temperature, water hardness, and stocking density on MS-222 response in three species of fish. Progressive Fish-Culturist $44: 138-141$. 
Wedemeyer, G. 1970. Stress of anesthesia with M.S. 222 and benzocaine in rainbow trout (Salmo gairdneri). Journal of the Fisheries Research Board of Canada 27:909-914. 
CHAPTER FIVE

Rearing and Emigration of Naturally Produced Snake River Fall Chinook Salmon Juveniles

\section{by}

W.P. Connor, H.L. Burge, and W.H. Miller

U.S. Fish and Wildlife Service,

Idaho Fishery Resource Office

Ahsahka, Idaho 83520, USA 


\section{Introduction}

Minimal data are available on the rearing and emigration of juvenile Snake River fall chinook salmon Oncorhynchus tshawytscha. When Snake River fall chinook salmon were listed as a threatened species under the Endangered Species Act (ESA; United States Fish and Wildlife Service 1988) in 1992, much of the contemporary information on these subyearling emigrants was based on our 1991 research (Connor et al. 1993). The purpose of our study is to increase the information on naturally produced Snake River fall chinook salmon juveniles for ESA recovery efforts. Our objectives in 1992 were: 1) describing the early life history and emigration timing of naturally produced snake River fall chinook salmon, and 2) estimating the influence of water flow, water temperature, and juvenile fall chinook salmon size on emigration rate.

\section{Study Area}

The study area included the snake River from Hells Canyon Dam to Lower Granite Dam (Figure 1). In 1992, we gathered data by seining and tagging juvenile chinook salmon in a reach bounded by Two Corral Creek at river kilometer (RK) 355 and Lower Granite Dam (RK 173); within this reach we seined 19 different systematic sites. Mean daily Snake River discharge at the United States 'Geological Survey gage at Anatone, Washington (RK 270) ranged from about 15,300 to 47,200 cubic ft/s (CFS) during sampling (Figure 2). Mean daily water temperature collected at Billy Creek (RK 265) ranged from about 9.5 to $18.4^{\circ} \mathrm{C}$ during sampling

(Figure 2).

\section{Methods}

\section{Data Collection}

Systematic samples.-Nineteen sites (Table 1) were beach seined once each week from 1 April until 14 May, 1992. Each site was normally seined three times in an upriver direction; each consecutive set started where the previous one ended. From 19 May to 11 June we seined only the lower 15 sites between RK 226 and RK 290. The beach seine we used from 1 April to 6 May had $0.32 \mathrm{~cm}$ mesh and measured $21.3 \mathrm{~m} \mathrm{x} 1.2 \mathrm{~m}$. This seine had a 1.7 $\mathrm{m}^{3}$ bag and a weighted multistranded mudline. On 12 May, we switched to a larger seine. The larger seine had $0.48 \mathrm{~cm}$ mesh and was $30.5 \mathrm{~m} \times 1.8 \mathrm{~m}$ with a $3.9 \mathrm{~m}^{3}$ bag. Each end of the seine was fitted with a bottom weighted brail equal in length to net depth and $15.2 \mathrm{~m}$ lead ropes. The seine was set parallel to shore 


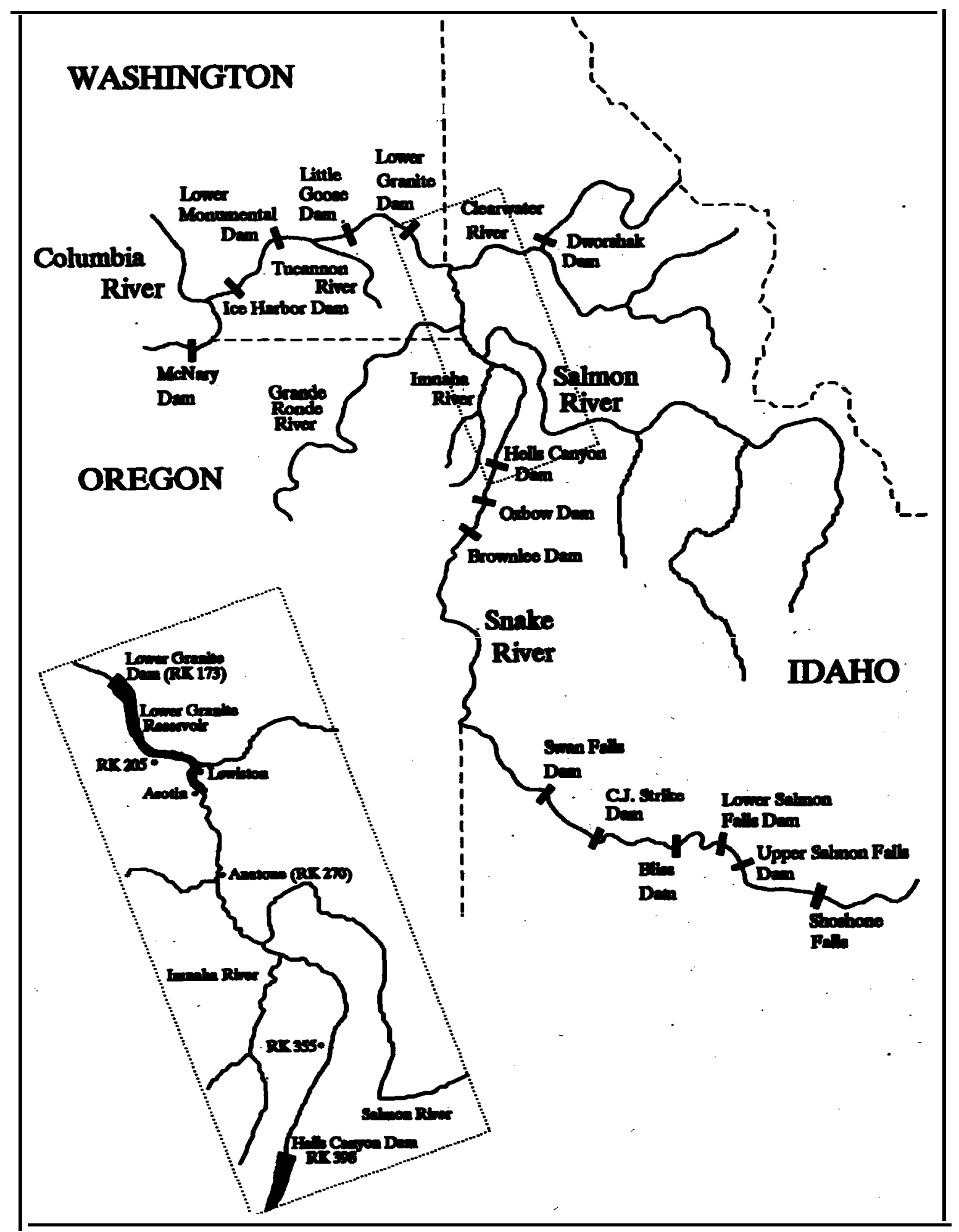

Figure 1.-Map of the Snake River drainage with an insert to show the 1992 seining area boundaries of RK 205 and RK 355. 


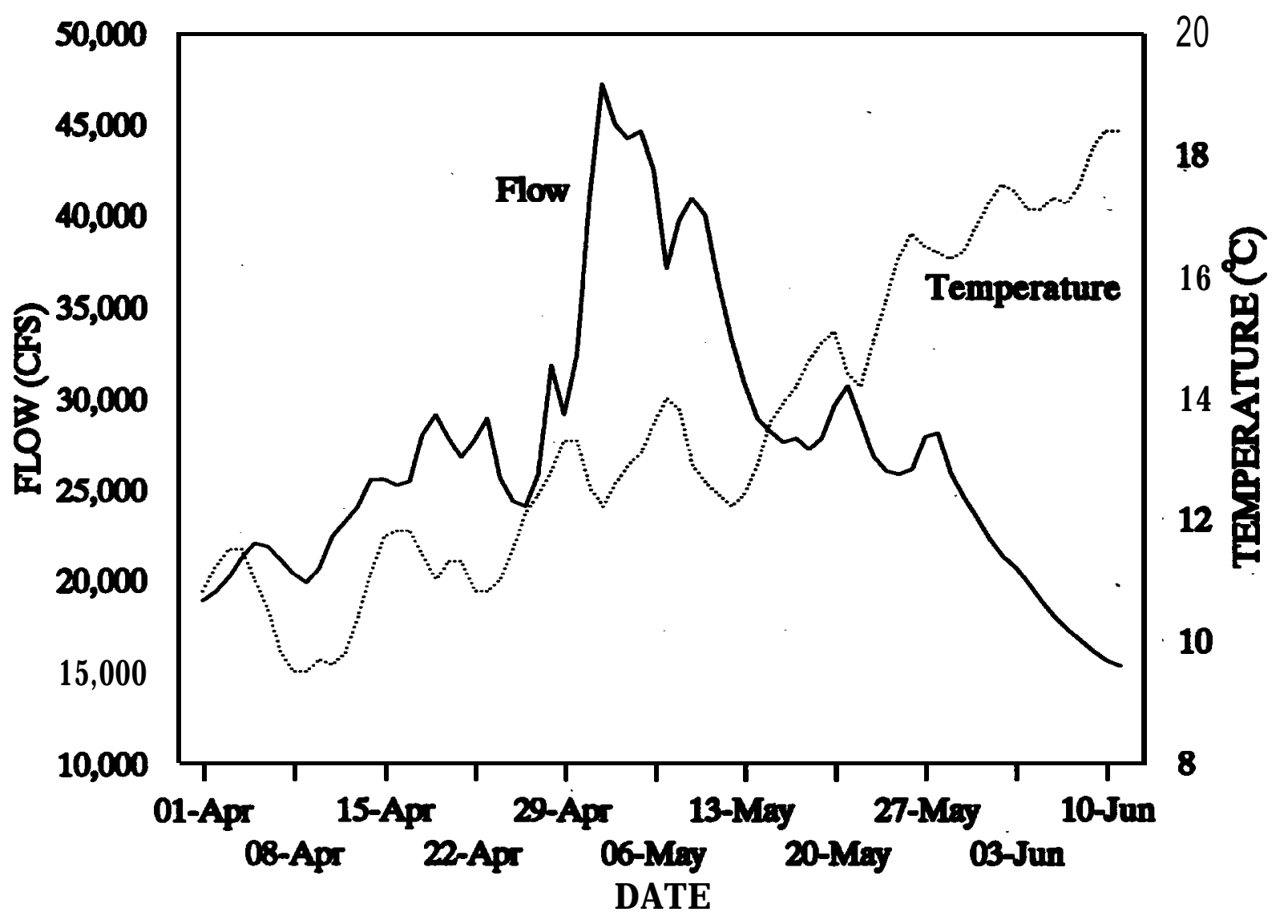

Figure 2.-Mean daily flows (RK 270) and temperature (RK 265) in the Snake River during the 1992 sampling period. 
from the stern platform of a $6.7 \mathrm{~m}$ jet boat. The net was then hauled straight into shore by both lead ropes. The smaller net sampled approximately $324 \mathrm{~m}^{2}$ of river to a depth of $1.2 \mathrm{~m}$, while the larger net sampled $465 \mathrm{~m}^{2}$ to a depth of $1.8 \mathrm{~m}$.

Table 1.-Sites seined for systematic fall chinook salmon juvenile sampling in the Snake River in 1992 .

\begin{tabular}{ll}
\hline River Kilometer & Side of River \\
\hline 226 & West \\
229 & East \\
232 & East \\
242 & East \\
242 & West \\
248 & West \\
$251 \mathrm{~A}$ & East \\
$251 \mathrm{~B}$ & East \\
254 & West \\
262 & East \\
272 & East \\
274 & East \\
280 & West \\
282 & East \\
290 & East \\
322 & East \\
328 & West \\
346 & West \\
355 & West \\
\hline
\end{tabular}

Grab samples.-Seine hauls made at locations other than, or adjacent to, systematic sampling sites were classified as grab samples. We collected fishes from 23 grab sites. Grab sites were selected based upon habitat features that were similar to our systematic seining sites. These sites are generalized by low velocity and sloping shore with minimal obstructions for landing a beach seine. Grab sites were sampled after systematic sites were finished for the day or on days when no systematic sampling was scheduled.

Anesthetic. - Once seined, chinook salmon were transferred to a 94.6 L oxygenated live-well supplied with water at river temperature, $100 \mathrm{~g}$ of $\mathrm{NaCl}$, and $12.5 \mathrm{~mL}$ of polyaqua. All chinook salmon were anesthetized in a dilute tricaine methanesulfonate (MS-222) solution of 2-5 mL of concentrated MS-222 to $18.9 \mathrm{~L}$ of water, which was buffered with $0.5 \mathrm{gm}$ of $\mathrm{NaHCO}_{3}$. The concentrate was prepared by mixing $100 \mathrm{gm}$ of powdered MS-222 in a $100 \mathrm{~mL}$ of 
water. The MS-222 concentrate was kept refrigerated and was stored in a dark plastic bottle. Chinook salmon were anesthetized in groups of 6-10 fish.

In-season race identification. We calculated a size limit to separate the smaller subyearling chinook salmon juveniles "in-season" from larger yearling chinook salmon. The size limit was calculated based on water temperature, projected fry emergence dates, and projected growth rate. Fork length (FL) of all anesthetized chinook salmon juveniles that obviously fit within the size limit were measured to the nearest millimeter. If the fish were out side of the size limit we measured FL of about 30 randomly sampled chinook salmon.

Water temperature data for the size limit calculation were collected at Pittsburg Landing (RK 347) and Billy Creek (RK 265) These temperature data were used to project fry emergence, documented to occur at 962 Celsius temperature units (CTUs; Arnsberg et al. 1992) after spawning. For the size limit calculation, emergent fry were estimated to be $38 \mathrm{~mm} \mathrm{FL}$ (Arnsberg et al. 1992), and estimated to have a growth rate of $1.4 \mathrm{~mm} / \mathrm{d}$ (Connor et al. 1993). Emergence timing had to be projected separately for chinook salmon juveniles collected above and below the Salmon River confluence because of differences in water temperature. We calculated the upper fall chinook salmon size limit in Table 2 using water temperatures from RK 265. A maximum upper limit of $110 \mathrm{~mm}$ was used since fall chinook salmon larger than this size were rare in 1991 (Connor et al. 1993). The lower fall chinook salmon size limit in Table 2 was calculated using a $60 \mathrm{~mm}$ minimum tagging size and water temperatures from RK 347 .

Table 2.-Upper and lower size limits calculated for in-season race identification of chinook salmon seined in the snake River, 1992 .

Limit

Estimated fall chinook salmon size by date

13-Apr 20-Apr 27-Apr 4-May 11-May 18-May 25-May 1-Jun 8-Jun

\begin{tabular}{|c|c|c|c|c|c|c|c|c|}
\hline Upper & 64 & 68 & 72 & 76 & 90 & 95 & 103 & 110 \\
\hline Lower & 60 & 60 & 60 & 60 & 60 & 60 & 60 & 60 \\
\hline
\end{tabular}


PITtagging.-Chinook salmon which fit within the size limits of Table 2 or had the sharper body features and smaller eyes we noted in fall chinook salmon during 1991 were Passive Integrated Transponder (PIT) tagged (Prentice et al 1990a). The minimum size limit for PIT tagging chinook salmon was $60 \mathrm{~mm} \mathrm{FL}$ based on laboratory data by colleagues (McCann et al. 1993). From 14 April to 14 May, 1992 we used a 50\% solution of iodine for a tag disinfectant. This disinfection method was based on a discussion with fish health experts at the American Fisheries Societies Smolt Survival Workshop '(February, 1992). Notably, the tags were not rinsed prior to injecting them into the chinook salmon. The excess iodine from the tag and the needle (about $0.05 \mathrm{~g}$ ) passively dispersed on the surface and edges of the insertion wound. Laboratory work to isolate the effects of the above iodine treatment were done on 15 May, 1992. Twenty-five hatchery fall chinook salmon juveniles ranging in size from $58-74 \mathrm{~mm} \mathrm{FL}$ were injected with $0.05 \mathrm{~g}$ of a 50\% iodine solution and 33 hatchery fall chinook salmon juveniles ranging in size from 62-72 $\mathrm{mm}$ FL served as controls. Mortality of the treatment and control groups was monitored for $96 \mathrm{~h}$.

From 19 May to 10 June 1992, we used 70\% ethyl alcohol to disinfect the tags. The disinfected tags were blotted dry prior to insertion into the fish. Chinook salmon juveniles were immobilized by placing them in a cool, wet, notched foam pad. Tags were manually implanted with a 12 gauge needle affixed to a syringe.

Recovery.-After tagging, we transferred the fish to an oxygenated 18.9 L recovery bucket filled with saline water $(20 \mathrm{gm}$ $\mathrm{NaCl}$ ) and $12.5 \mathrm{~mL}$ of polyaqua. The salmon were held in the recovery bucket for 15 min prior to a 24-h holding period in a $0.02 \mathrm{~m}^{3}$ minnow trap that was secured to the bottom of the river by weights. This 24-h holding procedure was implemented from 14 April to 13 May. After 13 May we released salmon immediately after the 15 min recovery period.

PIT-tagdata.-The data collected from the PIT-tagged chinook salmon juveniles were recorded in computer files (PIT Tag Work Group 1991). These tagging files were uploaded to the PIT Tag Information System (PITAGIS). Emigrating chinook salmon juveniles that bypass Lower Granite Dam turbines via the submersible travelling screen are monitored for PIT tags (Prentice et al. 1990b). Both PIT-tagging and PIT-tag detection data are available to interested parties through PITAGIS.

Electrophoresis.-A subsample of the PIT-tagged chinook salmon detected at Lower Granite Dam are diverted by a hydraulic slide gate. Diverted chinook salmon are scanned for tag codes and measured by Smolt Monitoring Program (SMP) personnel. When our tag codes were detected in chinook salmon a scale sample was 
taken for aging (Jerald 1983) and the fish was labeled and frozen. The Washington Department of Fisheries (WDF) validated the race of the frozen chinook salmon using tissue extracts and horizontal starch-gel electrophoresis (Abbersold et al. 1987).

\section{Data Analysis}

Post-season race separation.-The first step in our analysis was a description of the number and size of all the juvenile chinook salmon we beach seined. Then we used a simple process to separate out spring/summer chinook salmon data from fall chinook salmon data. We based our "post-season" separation of fall and spring/summer chinook salmon on data collected from our PITtagged, electrophoretically validated, fall chinook salmon juveniles diverted at Lower Granite Dam. The FL of the two known spring/summer chinook salmon were averaged. A line was then regressed through the FL of two spring/summer chinook salmon and the average FL calculated above. All fish smaller than this regressed upper size were separated as fall chinook salmon.

Emigration rate-We calculated emigration rate for each PITtagged fall chinook salmon by dividing the distance between the release site and Lower Granite Dam by the time the fish was at large before being detected at the dam. Multiple General Linear Hypothesis testing (MGLH; SYSTAT 1990) was used to test for relations between and among fall chinook salmon emigration rate and, (a) Snake River average discharge at Lower Granite Dam when the fish was at large (emigration flow), (b) the snake River average water temperature when the fish was at large (emigration temperature), (c) Snake River water temperature when the fish was released (release temperature), and (d) the FL of the PIT-tagged fall chinook salmon when it was released (release length; Appendix 5).

Results

\section{Overview of Seining and Tagging}

We beach seined 3,156 chinook salmon juveniles between 1 April and 10 June, 1992 at 19 systematic and 23 grab sites (Figure 3 ). The 2,710 chinook salmon we measured ranged from 34 to $210 \mathrm{~mm} \mathrm{FL} \mathrm{(Figure} \mathrm{4).} \mathrm{We} \mathrm{PIT} \mathrm{tagged} \mathrm{1,100} \mathrm{(total} \mathrm{before} \mathrm{post-}$ season race separation by $F L$ ) of the 3,156 chinook salmon between 14 April and 10 June, 1992 (Figure 5). We only released 1,051 of the 1,100 tagged chinook salmon as a result of post-tagging mortality. 


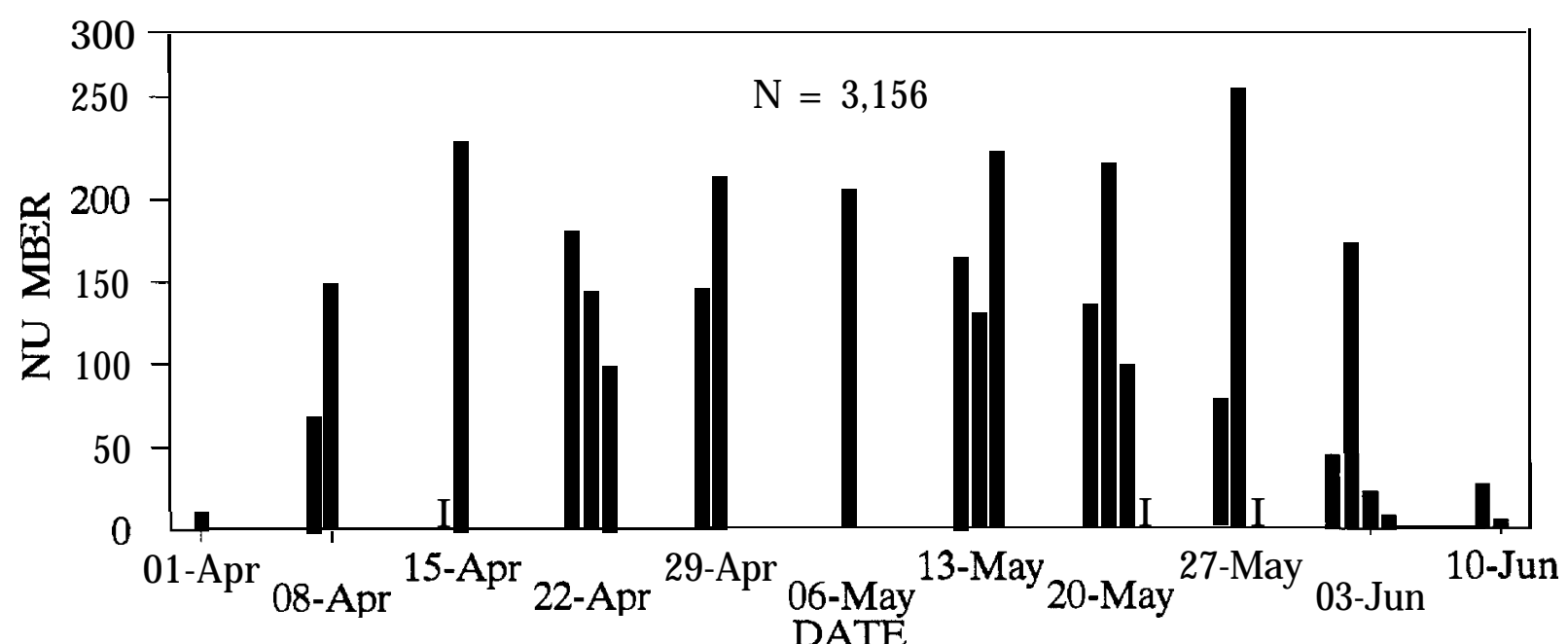

Figure 3.-Number of chinook salmon 'uveniles seined by date in the Snake River between RK 205 and RK 355, 1 April to 10 June, 1992.

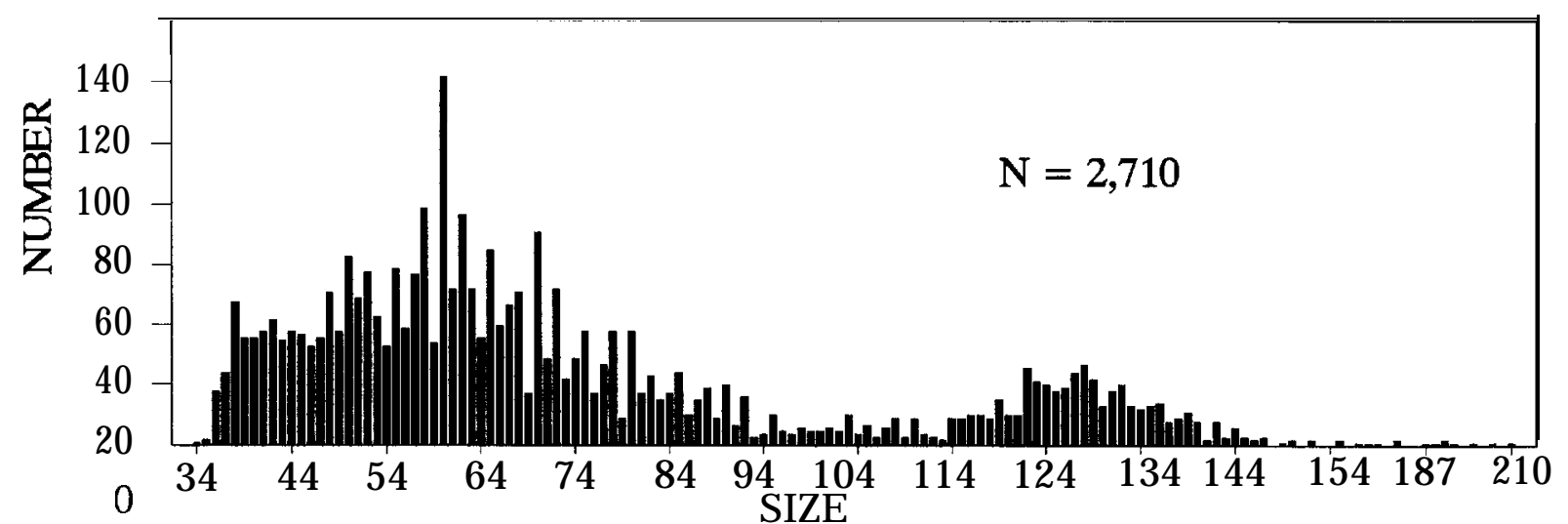

Figure 4. - Length frequency of chinook salmon $(\mathrm{mm})$ Juveniles seined in the Snake River between RK 205 and RK 355, 1 April to 10 June, 1992.

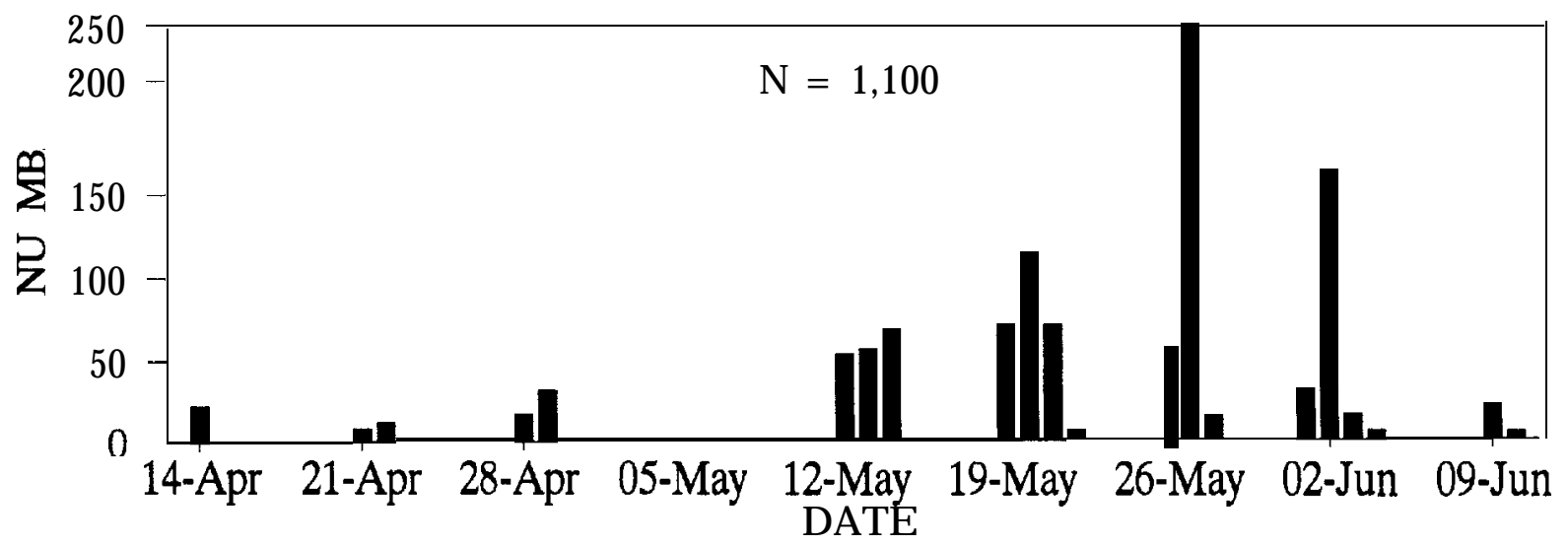

Figure S.-Number of chinook salmon juveniles PIT tagged by date in the Snake River between RK 205 and RK 290, 14 April to 10 June, 1992. 
Weekly post-tagging mortality of PIT-tagged chinook salmon juveniles ranged from 0 to 22.7\% from the week of 12 April to 7 June (Figure 6). The highest mortality occurred from 12 April to 13 May when we used unrinsed iodine disinfected tags and held salmon in minnow traps for 24-h after tagging. In the laboratory on 15 May, we determined that the quantity of iodine we used as an antibacterial treatment killed PIT-tagged fall chinook salmon juveniles when injected into their body cavities (Table 3). Mortality began $24 \mathrm{~h}$ after the fish were injected with iodine. After $96 \mathrm{~h}$ cumulative mortalities of injected and control fall chinook salmon were 52\% and $0 \%$, respectively. Weekly posttagging mortality decreased to a range of 0 to $1.1 \%$ when we switched to alcohol disinfected blotted tags and a 15-min recovery period (Figure 6 ). No $24-\mathrm{h}$ holding tests were done in the snake River after switching to alcohol as a tag disinfectant.

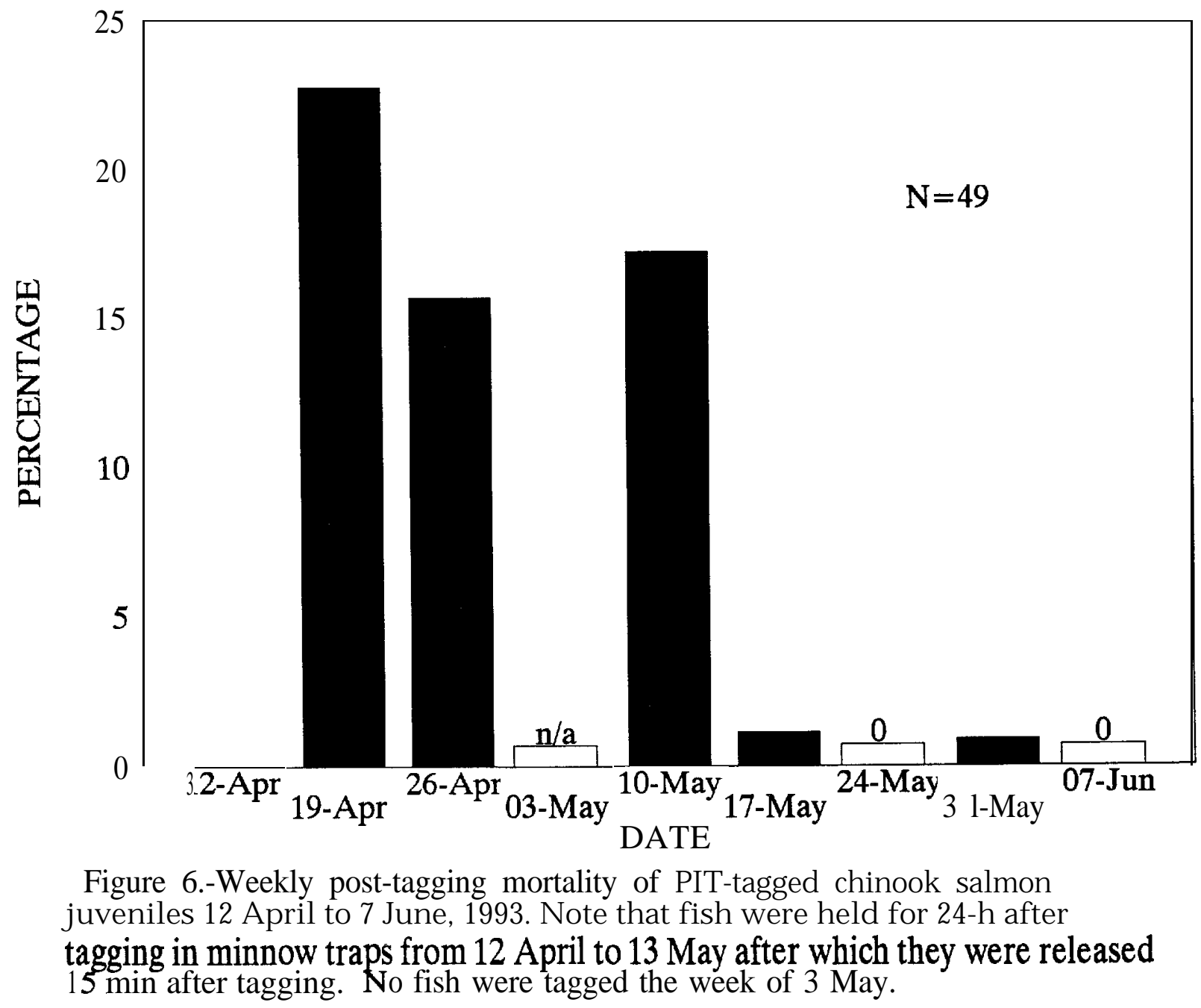


Table 3.-Ninety-six hour mortality of hatchery fall chinook salmon injected with a $0.05 \mathrm{~g}$ solution of $50 \%$ iodine and control fish which were not injected with iodine, 15 May 1993.

\begin{tabular}{ccccc}
\hline Treatment & $\begin{array}{c}\text { Sample } \\
\text { size }\end{array}$ & $\begin{array}{c}\text { Holding duration } \\
(\mathrm{h})\end{array}$ & $\begin{array}{c}\text { Daily } \\
\text { mortality }\end{array}$ & $\begin{array}{c}\text { Cumulative } \\
\text { mortality }\end{array}$ \\
\hline \multirow{2}{*}{ Injected } & 25 & 24 & 0 & 0 \\
& & 48 & 12 & 48 \\
& 72 & 1 & 52 \\
Control & 36 & 24 & 0 & 52 \\
& & 48 & 0 & 0 \\
& 72 & 0 & 0 \\
& 96 & 0 & 0 \\
\hline
\end{tabular}

A total of 51 chinook salmon juveniles we PIT tagged were detected at Lower Granite Dam, of which 16 were diverted by the sliding gate. Electrophoresis validated 14 of the above 16 fish as fall chinook salmon and the remaining two as spring/summer chinook salmon (Table 4). The 14 fall chinook salmon juveniles grew an average of $1.0 \mathrm{~mm} / \mathrm{d}(\mathrm{SD}= \pm 0.3 \mathrm{~mm} / \mathrm{d}$; range $=0.3-1.5$ $\mathrm{mm} / \mathrm{d}$ ) and had a mean $\mathrm{FL}$ of $111.2 \pm 11.2 \mathrm{~mm}$.

The post-season upper size limit for fall chinook salmon provided a fairly accurate method to separate the data by chinook salmon race (Figure 7). Applying the post-season upper size limit to the FL of the 2,710 juvenile chinook salmon we seined and measured identified 2,056 as fall chinook salmon.

\section{Systematic Samples}

Systematic beach seining collected 1,309 of the 2,056 fall chinook salmon. Fall chinook salmon captured during systematic sampling ranged in FL from 34 to $99 \mathrm{~mm}$ (mean = 58 +11 mm; Figure 8). Back calculated emergence timing estimates for the 1,309 fall chinook salmon ranged from 18 March to 25 May (Figure 9). The estimated pattern of emergence appears bimodal with an early peak on 31 March and a later peaks about 22 to 25 April.

Mean catch per unit effort (CPUE) of fall chinook salmon, by week from 29 March to 7 June, ranged from 0.3 to 8.5 (Figure 10). There was no marked change in CPUE the week of 10 May when we switched to a larger seine. The peak CPUE of 8.5 occurred the week of 17 May. Mean CPUE dropped quickly after the 17 May peak through the week of 7 June when we quit sampling. The overall 1992 mean CPUE was 2.6 . 
Table 4.-Data for chinook salmon juveniles PIT tagged in the Snake River, diverted at Lower Granite Dam, and analyzed by electrophoresis, 1992.

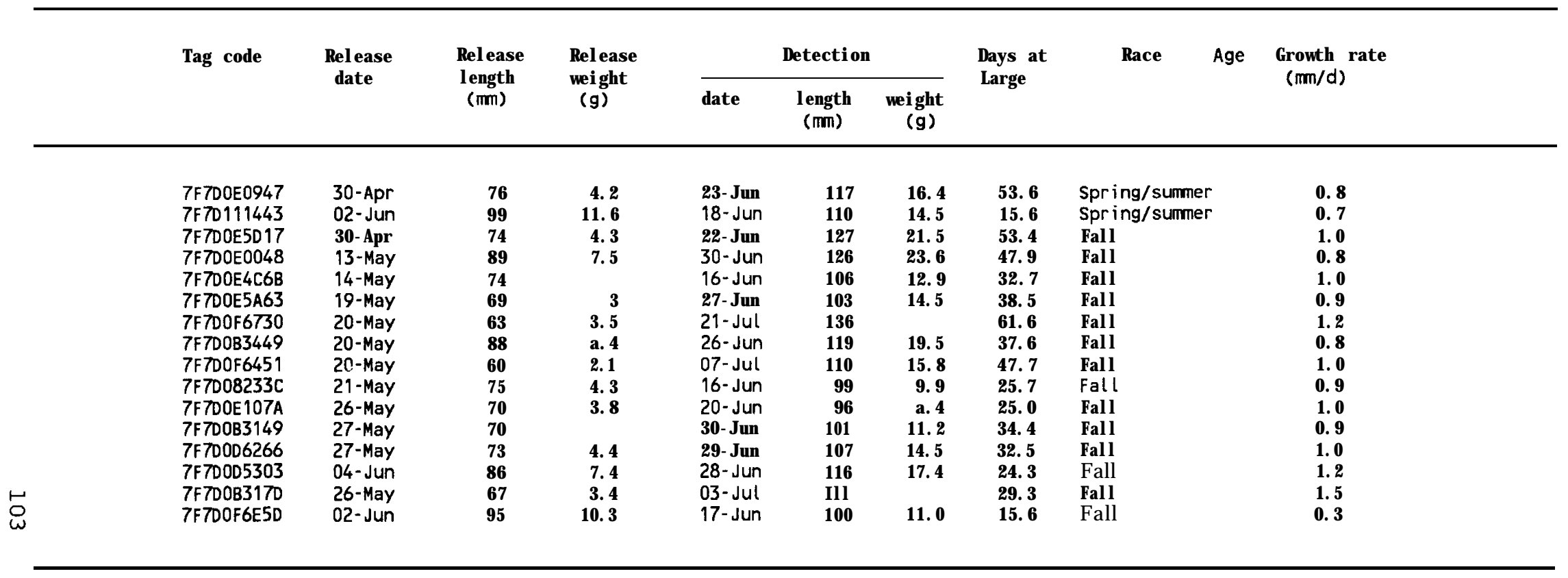




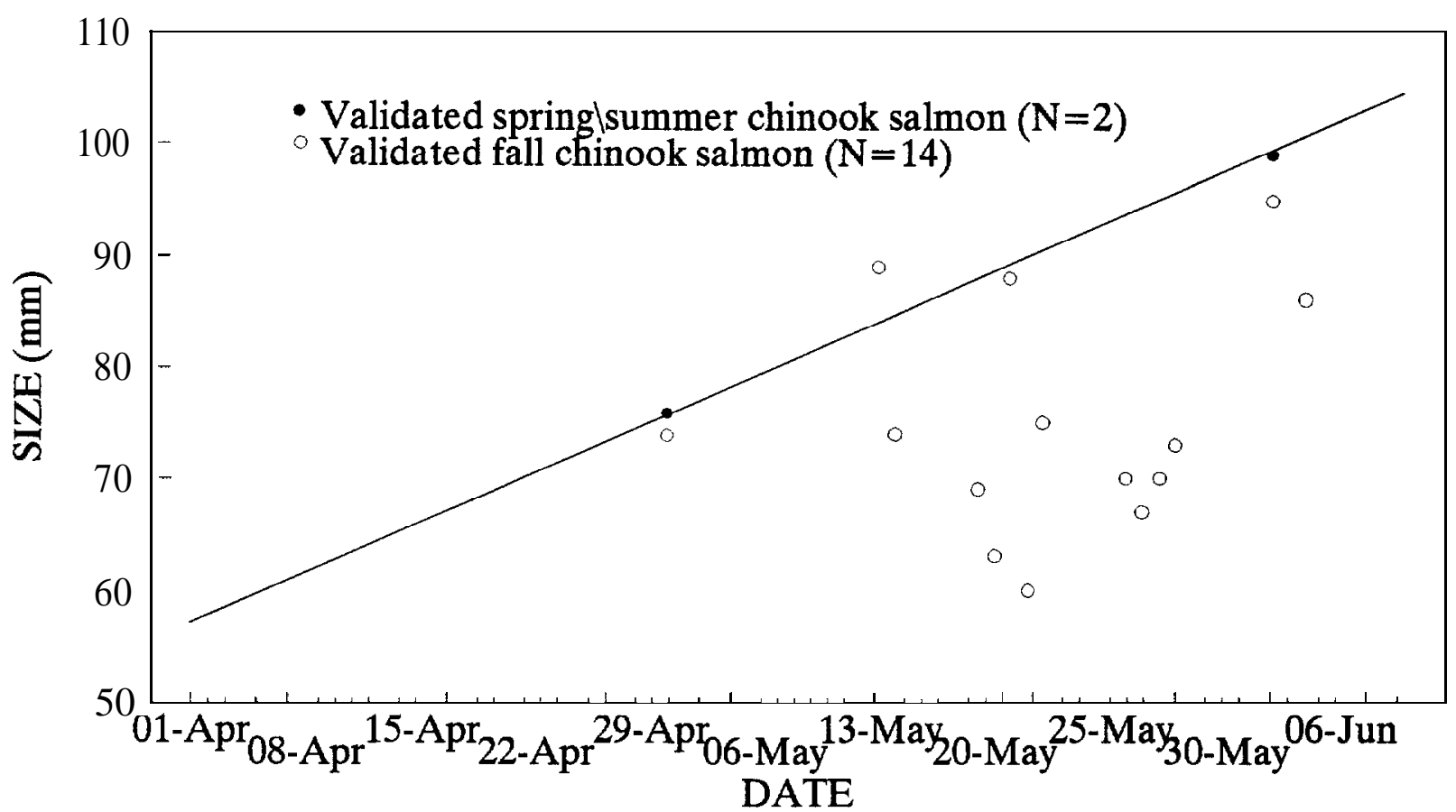

Figure 7.- Testing the applicability of the "post-season" size limit using chinook salmon juveniles which were seined and PIT tagged in the Snake River, diverted at Lower Granite Dam, and subjected to electrophoresis, 1992.

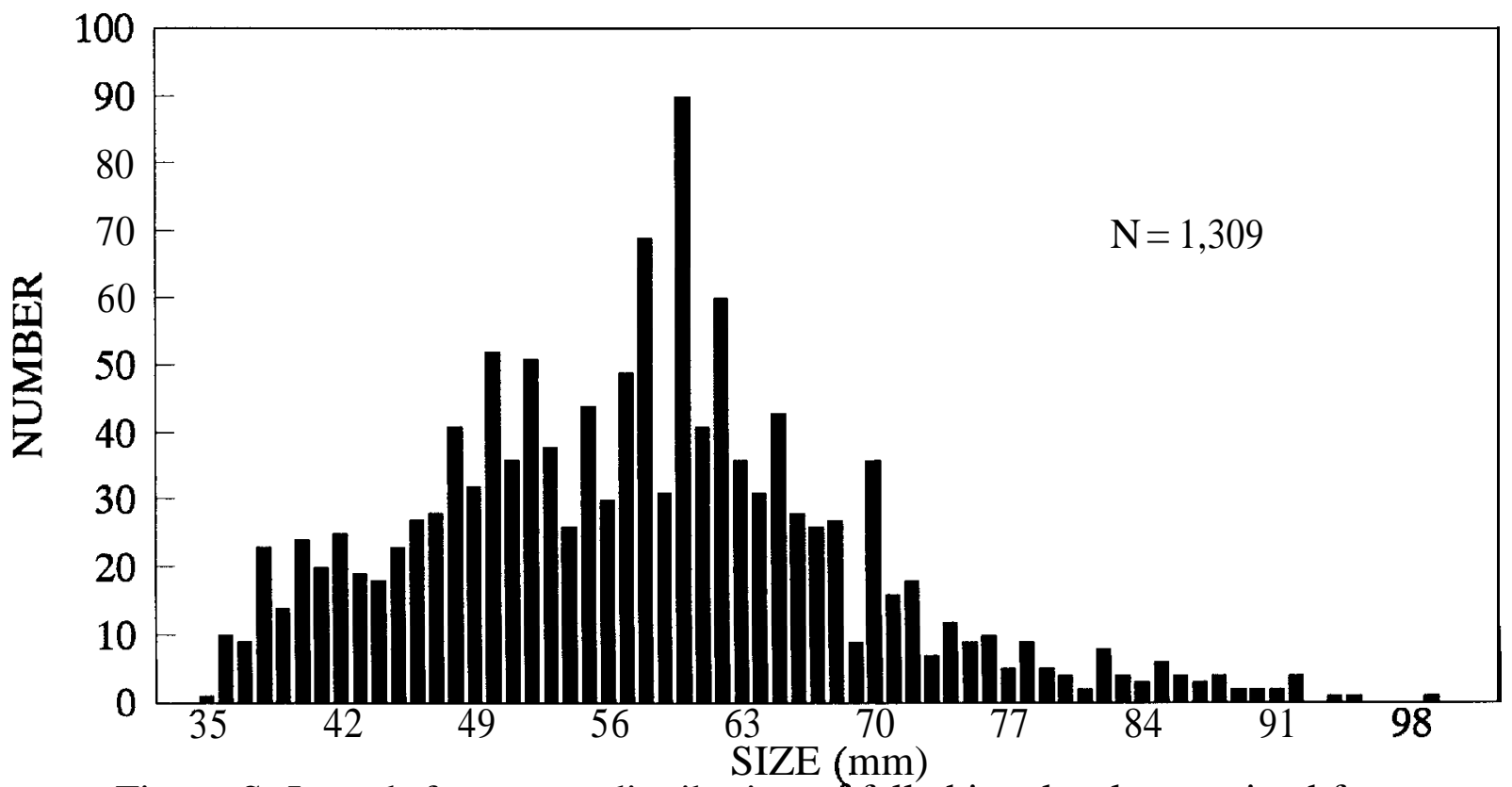

Figure S.-Length frequency distribution of fall chinook salmon seined from the Snake River by systematic sampling, 1 April - 10 June, 1992. 


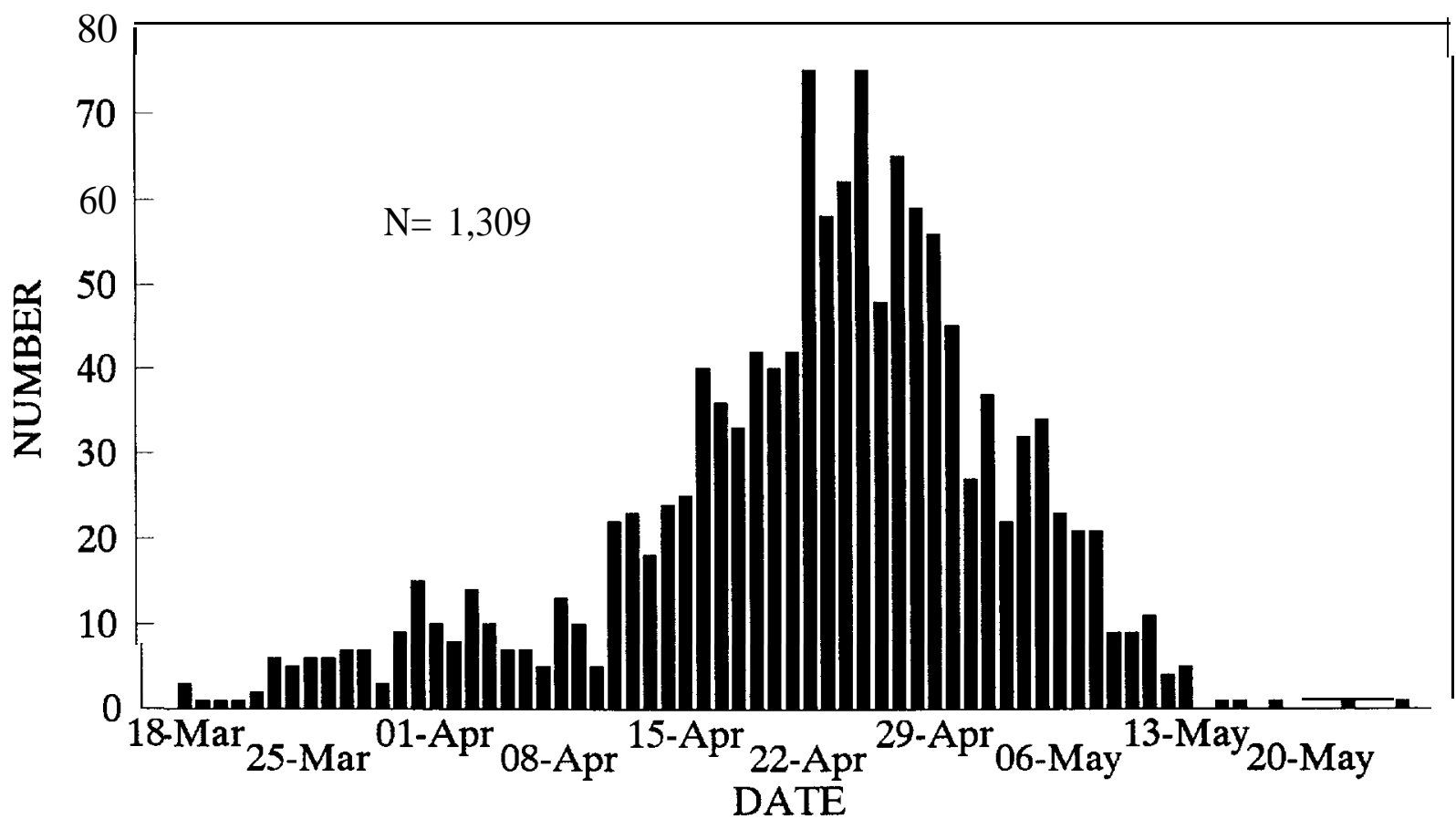

Figure 9.-Snake River fall chinook salmon emergence timing in 1992 back calculated using the release size of each fish, individual growth rates or the the average growth rate of $1.0 \mathrm{~mm} / \mathrm{d}$.

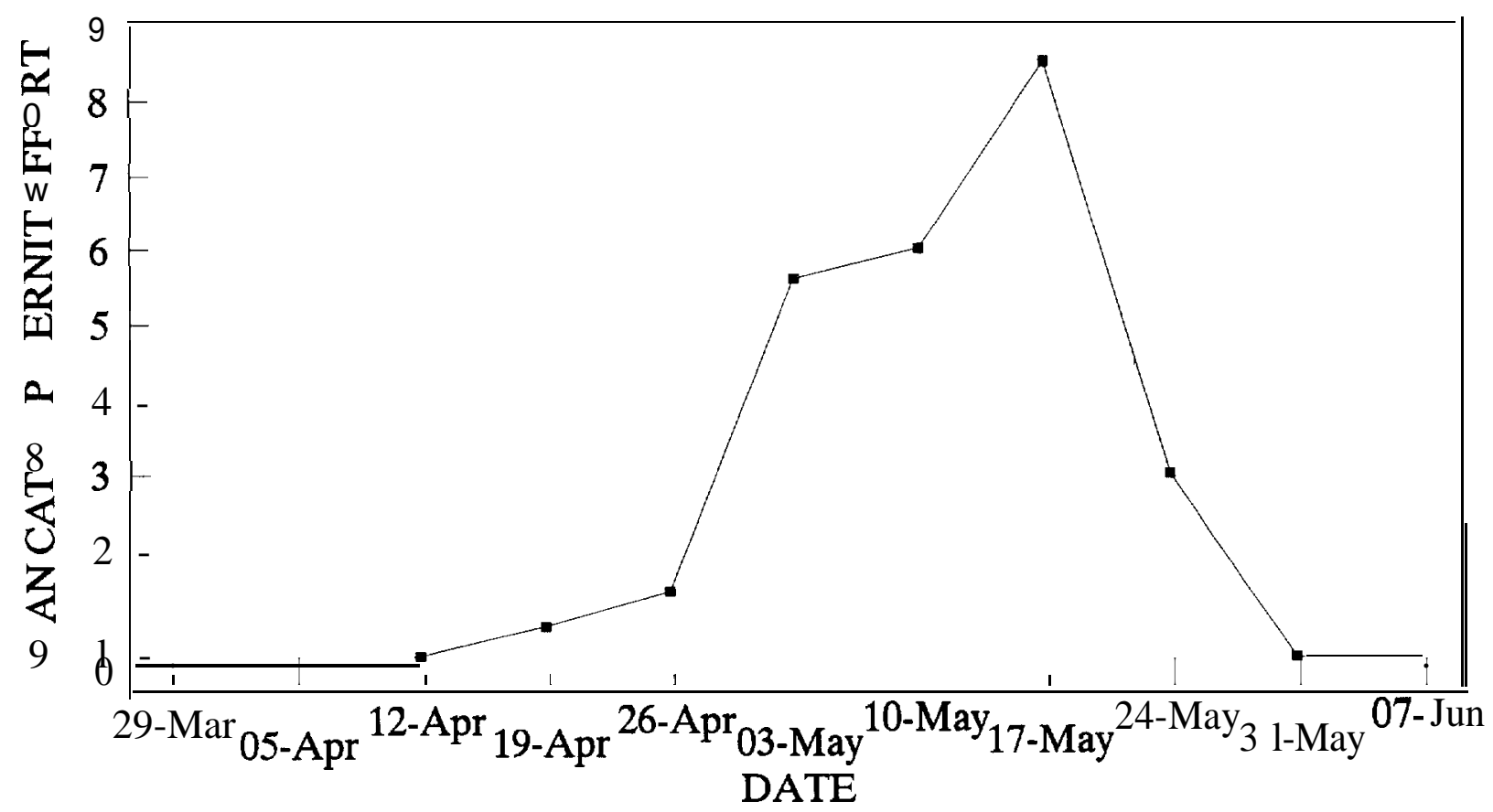

Figure 10.-Mean catch per unit effort of Snake River fall chinook salmon juveniles by sampling week, 1992. 
The 1992 mean CPUE of fall chinook salmon varied by site (identified as a river kilometer; Figure 11). The lowest 1992 mean CPUE occurred at RK 346, where no fall chinook salmon were caught and the highest overall CPUE of 8.1 occurred at RK 282 followed by 6.5 at RK 248 .

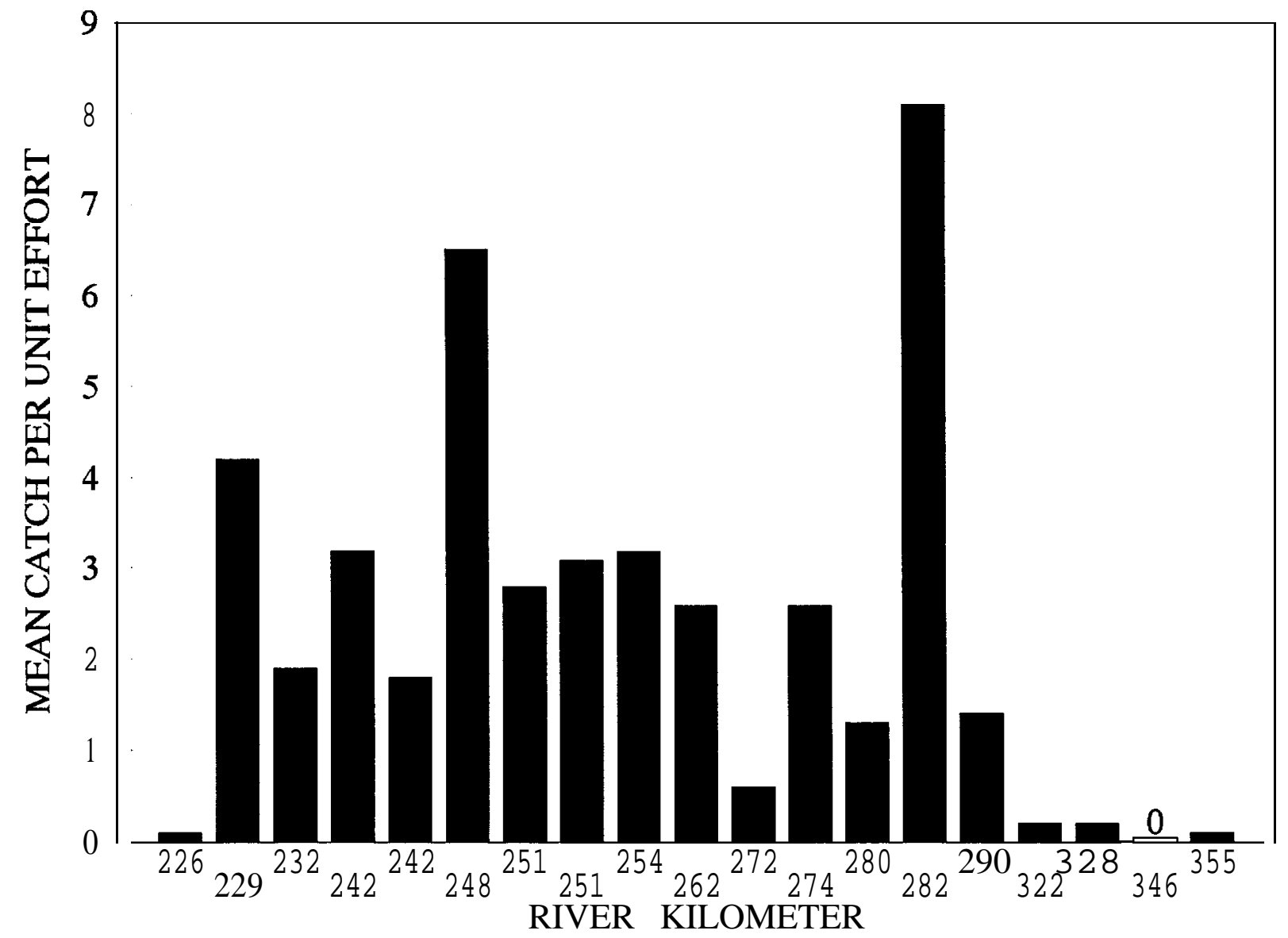

Figure 11-- Mean overall catch per unit effort of Snake River fall chinook salmon juveniles by river kilometer, 1 April - 11 June, 1992.

\section{Combined Grab and Systematic Samples}

The total number of fall chinook salmon we PIT tagged in combined grab and systematic samples was 947 . The 947 fall chinook salmon from the combined sample were released between the dates of 15 April and 10 June (Figure 12). The peak release of PIT-tagged fall chinook salmon from the combined sample was on 27 May $(N=230)$. PIT-tagged fall chinook salmon from the combined sample were released between RK 226 and RK 290; most releases were at RK 251 ( $\mathrm{N}=220$; Figure 13). The mean FL of PIT-tagged fall chinook salmon at release in 1992 was $70 \pm 9 \mathrm{~mm}$ and fish ranged from 60 to $99 \mathrm{~mm}$ FL (Figure 14). 


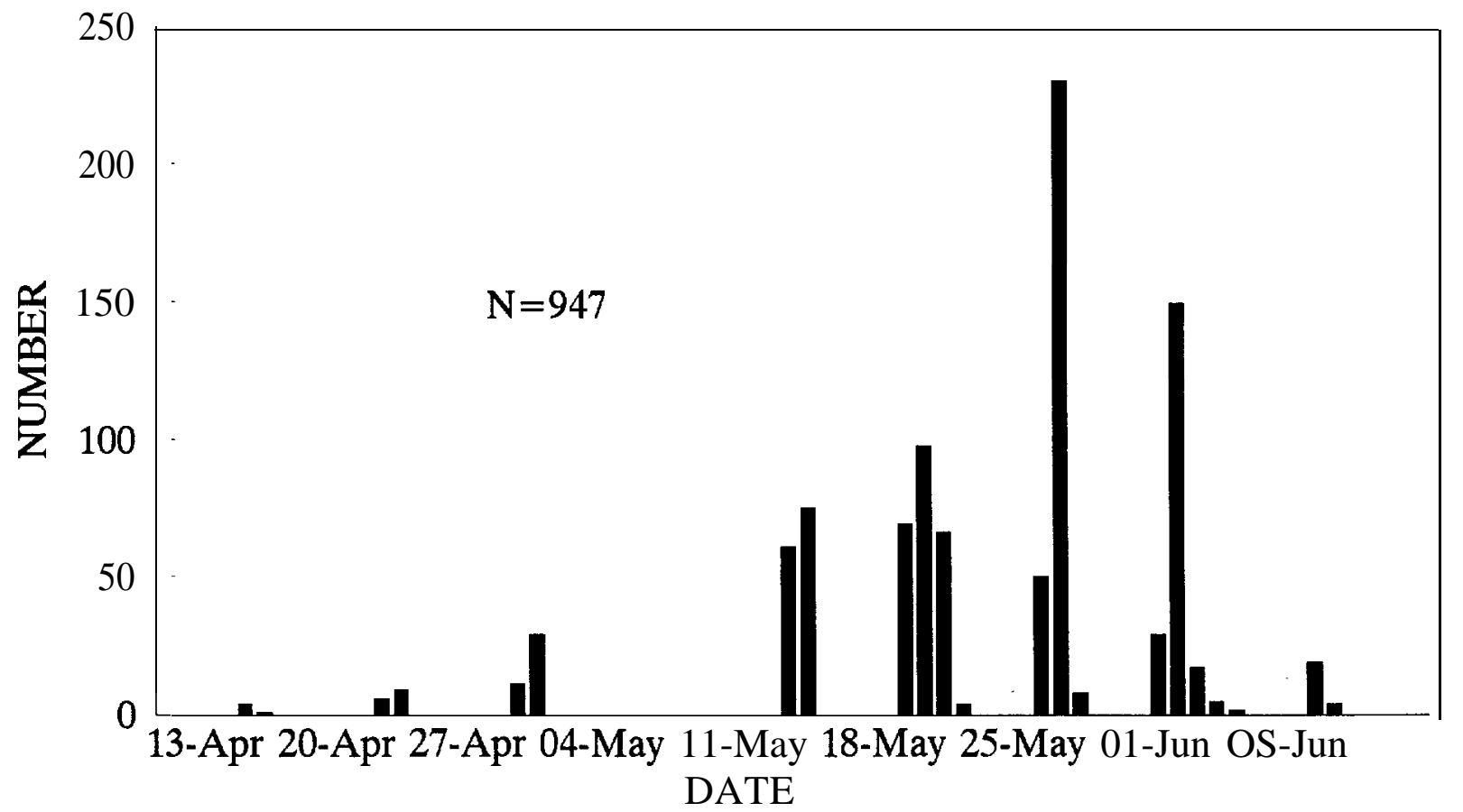

Figure 12.- Number of PIT-tagged fall chinook salmon released by date in the Snake River through combined systematic and grab samples collected between RK 211 and RK 290, 1992.

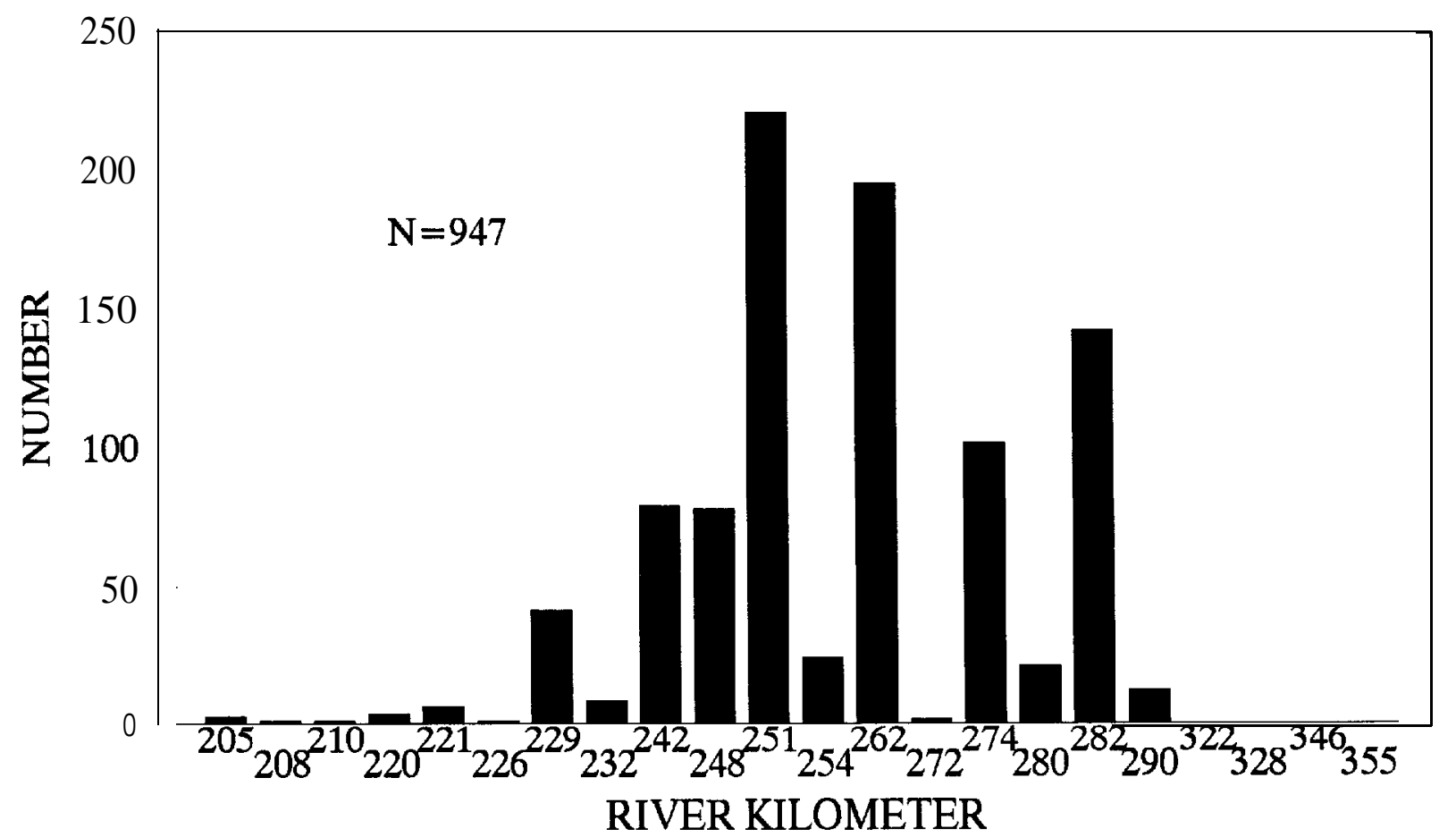

Figure 13--Number of Snake River fall chinook salmon PIT tagged by river kilometer by combined systematic and grab sampling, 15 April - 10 June, 1992. 


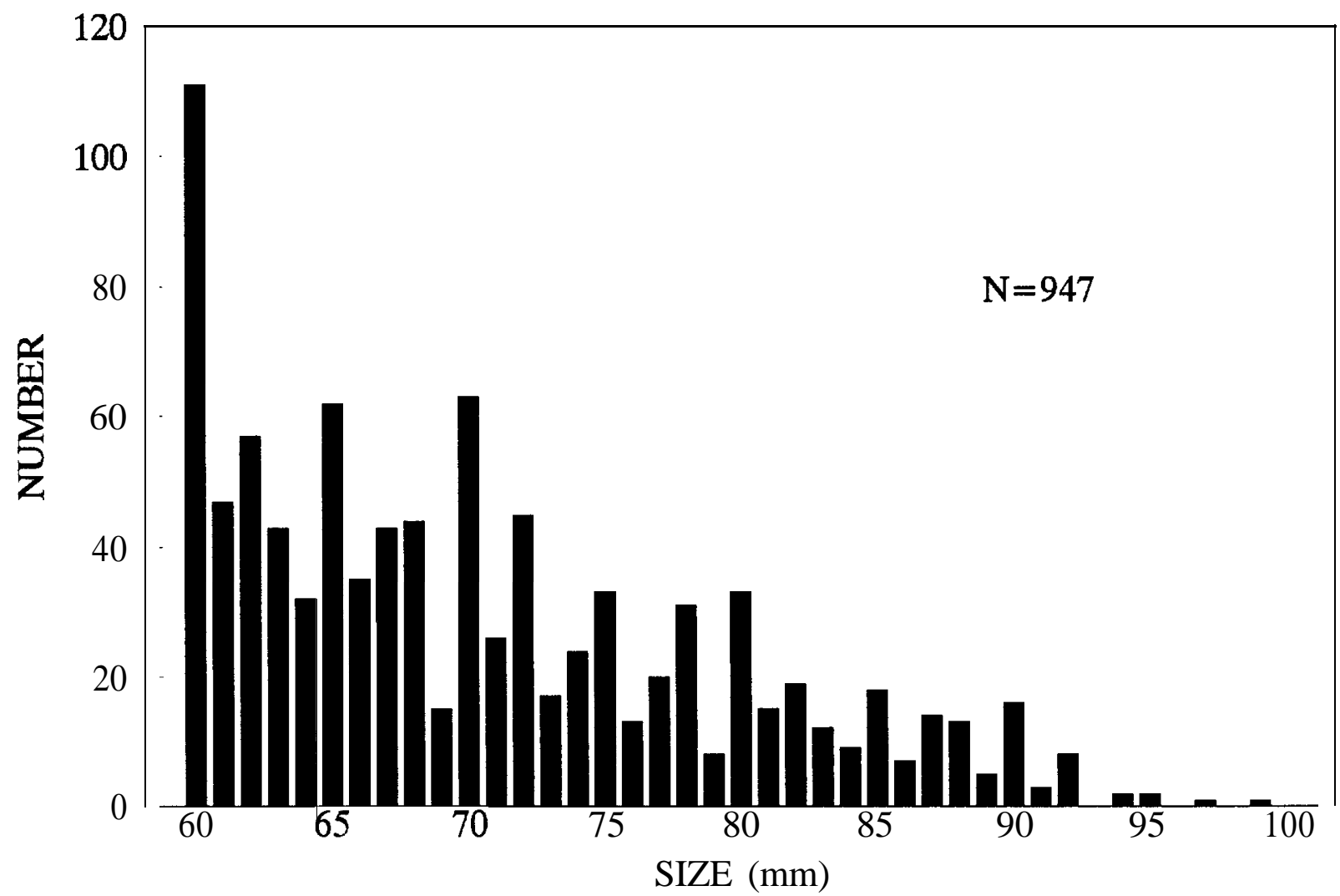

Figure 14.- Length frequency distribution of fall chinook salmon PIT tagged in the Snake River by combined systematic and grab sampling, 1992.

Through combined sampling we recaptured 66 PIT-tagged fall chinook salmon once and 3 twice (recapture rate $=7.3 \% ;$ Table 5). Recapture interval ranged from 1 to 27 d with the most common interval of $5 \mathrm{~d}$. Seven PIT-tagged fall chinook salmon were recaptured downstream of their original tagging site. Downstream movement ranged from 1 to $30 \mathrm{~km}$.

Thirty-three PIT-tagged fall chinook salmon were detected at Lower Granite Dam between 4 May and 21 July, 1992 (Figure 15). Detection of tagged fall chinook salmon at Lower Granite peaked on 23 June $(\mathrm{N}=5)$ and the median date of arrival was 22 June. PIT-tagged fall chinook salmon required from 3.5 to $61.6 \mathrm{~d}$ to reach Lower Granite Dam after the date of their last release (Figure 16) and their emigration rates to the dam averaged 3.6 $\mathrm{km} / \mathrm{d}(\mathrm{SD}= \pm 1.8 \mathrm{~km} / \mathrm{d}$, range $=1.1-9.3 \mathrm{~km} / \mathrm{d} ;$ Figure 17). 
Table 5.-PIT-tagged fall chinook salmon juveniles recaptured by beach seine in the Snake River, 1992.

\begin{tabular}{|c|c|c|c|c|c|c|c|c|c|c|c|c|c|c|}
\hline \multirow[t]{2}{*}{ Tag code } & \multicolumn{4}{|c|}{ Rel ease } & \multicolumn{4}{|c|}{ Fi rst recapt ure } & \multicolumn{4}{|c|}{ Second recapt ure } & \multirow{2}{*}{$\begin{array}{l}\text { Ti ne } \\
\text { i nterval } \\
\text { (d) }\end{array}$} & \multirow{2}{*}{$\begin{array}{l}\text { K I onet ers } \\
\text { travel I ed } \\
\text { downst ream }\end{array}$} \\
\hline & date & $\begin{array}{l}\text { ngt h } \\
\text { mm) }\end{array}$ & $\begin{array}{l}\text { uei ght } \\
\text { (g) }\end{array}$ & ki l onet er & date I & $\begin{array}{l}\text { igt h } \\
\text { m(m) }\end{array}$ & $\begin{array}{l}\text { wei ght } \\
\text { (g) }\end{array}$ & ki I onet er & date & $\begin{array}{l}\text { I ength } \\
(\mathrm{mm})\end{array}$ & $\begin{array}{c}\text { wei ght } \\
\text { (g) }\end{array}$ & ki I onet er & & \\
\hline 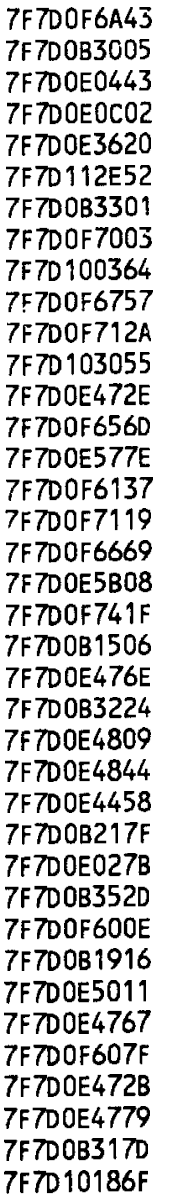 & 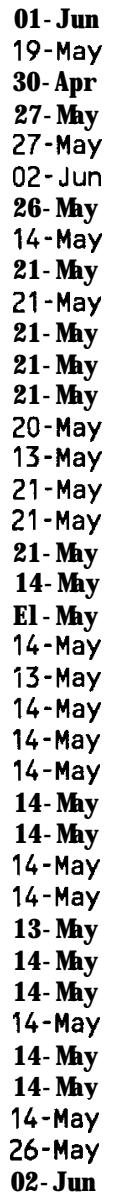 & $\begin{array}{l}82 \\
64 \\
61 \\
77 \\
62 \\
90 \\
60 \\
70 \\
76 \\
76 \\
87 \\
61 \\
84 \\
62 \\
60 \\
62 \\
66 \\
62 \\
60 \\
78 \\
66 \\
80 \\
60 \\
67 \\
74 \\
60 \\
70 \\
74 \\
61 \\
63 \\
70 \\
61 \\
71 \\
67 \\
62 \\
65 \\
67 \\
66\end{array}$ & $\begin{array}{l}1.7 \\
2.9 \\
4.8 \\
2.7 \\
7.5 \\
2.5 \\
\\
4.6 \\
4.9 \\
8.3 \\
2.4 \\
6.4 \\
2.7 \\
2.6 \\
2.8 \\
3.3 \\
3.2 \\
5.5 \\
6.8\end{array}$ & $\begin{array}{l}262 \\
280 \\
274 \\
274 \\
290 \\
250 \\
251 \\
282 \\
251 \\
251 \\
251 \\
251 \\
251 \\
248 \\
251 \\
251 \\
251 \\
251 \\
282 \\
251 \\
282 \\
251 \\
274 \\
282 \\
282 \\
282 \\
280 \\
282 \\
274 \\
254 \\
282 \\
282 \\
282 \\
229 \\
282 \\
282 \\
251 \\
250\end{array}$ & 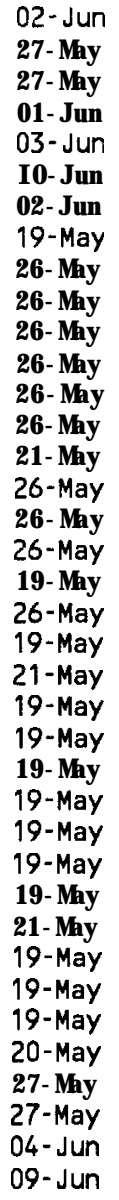 & $\begin{array}{l}83 \\
70 \\
85 \\
81 \\
70 \\
97 \\
67 \\
70 \\
77 \\
78 \\
92 \\
67 \\
88 \\
66 \\
68 \\
67 \\
71 \\
67 \\
63 \\
83 \\
67 \\
88 \\
62 \\
75 \\
77 \\
62 \\
72 \\
78 \\
63 \\
72 \\
73 \\
62 \\
70 \\
68 \\
78 \\
77 \\
75 \\
72\end{array}$ & $\begin{array}{r}0 \\
3.9 \\
6.4 \\
0 \\
0 \\
11.4 \\
3.4 \\
3.6 \\
5.8 \\
5.9 \\
9 \\
3.5 \\
8.2 \\
3.3 \\
2.8 \\
3.5 \\
4.4 \\
3.8 \\
2.6 \\
6.9 \\
2.7 \\
7.4 \\
2.5 \\
4.1 \\
4.8 \\
2.8 \\
4.5 \\
4.7 \\
2.5 \\
3.9 \\
3.8 \\
2.7 \\
3.5 \\
3.6 \\
0 \\
4.7 \\
5.1 \\
4.1\end{array}$ & $\begin{array}{l}232 \\
262 \\
262 \\
262 \\
282 \\
248 \\
250 \\
282 \\
251 \\
251 \\
251 \\
251 \\
251 \\
248 \\
251 \\
251 \\
251 \\
251 \\
282 \\
251 \\
282 \\
251 \\
274 \\
282 \\
282 \\
282 \\
280 \\
282 \\
274 \\
254 \\
282 \\
282 \\
282 \\
229 \\
282 \\
274 \\
251 \\
250\end{array}$ & 20- May & 84 & 4.4 & 242 & $\begin{array}{r}1 \\
8 \\
27 \\
5 \\
7 \\
8 \\
7 \\
5 \\
5 \\
5 \\
5 \\
5 \\
\\
5 \\
6 \\
8 \\
8 \\
5 \\
5 \\
5 \\
5 \\
5 \\
5 \\
8 \\
5 \\
5 \\
5 \\
5 \\
6 \\
6 \\
5 \\
5 \\
8 \\
13 \\
5 \\
5 \\
6 \\
13 \\
13 \\
9 \\
7\end{array}$ & $\begin{array}{r}30 \\
18 \\
12 \\
12 \\
8 \\
2 \\
1\end{array}$ \\
\hline
\end{tabular}


Table 5. (Conti nued

\begin{tabular}{|c|c|c|c|c|c|c|c|c|c|c|c|c|c|c|}
\hline \multirow[t]{2}{*}{ Tag code } & \multicolumn{4}{|c|}{ Rel ease } & \multicolumn{4}{|c|}{ Fi rst recapt ure } & \multicolumn{4}{|c|}{ Second recapt ure } & \multirow{2}{*}{$\begin{array}{l}\text { Ti ne } \\
\text { i nterval } \\
\text { (d) }\end{array}$} & \multirow{2}{*}{$\begin{array}{l}\text { K I onet ers } \\
\text { travel I ed } \\
\text { downst ream }\end{array}$} \\
\hline & date & $\begin{array}{l}\text { Length } \\
\text { (mm) }\end{array}$ & $\begin{array}{l}\text { wei ght } \\
(g)\end{array}$ & ki I onet er & date & $\begin{array}{l}\text { engt h } \\
(\mathrm{mm})\end{array}$ & $\begin{array}{l}\text { wei ght } \\
\text { (g) }\end{array}$ & ki I onet er & date & $\begin{array}{l}\text { I ength } \\
\text { (mm) }\end{array}$ & $\begin{array}{l}\text { wei ght } \\
(g)\end{array}$ & ki I onet er & & \\
\hline $\begin{array}{l}\text { 7F7D0E5B4E } \\
\text { 7F7DOE3B22 } \\
\text { 7F7DOB3512 } \\
\text { 7F7D0E5260 } \\
\text { 7F7DOF70666 } \\
\text { 7F7D101753 } \\
\text { 7F7DOF2B3C } \\
\text { 7F7D101D51 } \\
\text { 7F7D112826 } \\
\text { 7F7D10050E } \\
\text { 7F7DOF6426 } \\
\text { 7F7DOB3415 } \\
\text { 7F7D0E 1B13 } \\
\text { 7F7D0F2F7F } \\
\text { 7F7DOD6F79 } \\
\text { 7F7D10003B } \\
\text { 7F7D0F6E6C } \\
\text { 7F7D0E471F } \\
\text { 7F7D0B2840 } \\
\text { 7F7D0B2D1E } \\
\text { 7F7D0B265E } \\
\text { 7F7D0E3530 } \\
\text { 7F7D0F2D43 } \\
\text { 7F7D0E1E49 } \\
\text { 7F7DOE2333 } \\
\text { 7F7DOE3C22 } \\
\text { 7F7D0E237E } \\
\text { 7F7D0E1B37 }\end{array}$ & 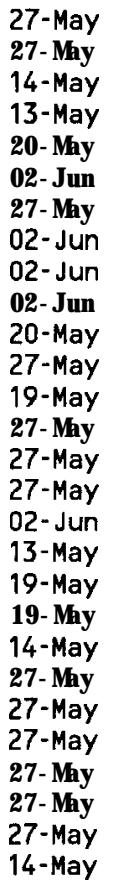 & $\begin{array}{l}75 \\
60 \\
71 \\
79 \\
66 \\
65 \\
80 \\
75 \\
81 \\
78 \\
62 \\
61 \\
70 \\
78 \\
72 \\
68 \\
73 \\
60 \\
64 \\
64 \\
64 \\
70 \\
75 \\
72 \\
72 \\
74 \\
68 \\
68\end{array}$ & $\begin{array}{l}4.7 \\
\\
6.7 \\
3.6 \\
3.5 \\
5.7 \\
5.2 \\
5.7 \\
6.4 \\
3 \\
2.5 \\
3.8 \\
5.5 \\
4.5 \\
2.9 \\
4.7 \\
2.2 \\
2.7 \\
2.8 \\
4.2 \\
5.2 \\
4.2 \\
3.8 \\
4.3 \\
3.4\end{array}$ & $\begin{array}{l}274 \\
282 \\
282 \\
251 \\
242 \\
250 \\
262 \\
250 \\
250 \\
250 \\
242 \\
274 \\
282 \\
262 \\
262 \\
262 \\
242 \\
262 \\
274 \\
282 \\
282 \\
262 \\
262 \\
262 \\
262 \\
262 \\
262 \\
282\end{array}$ & 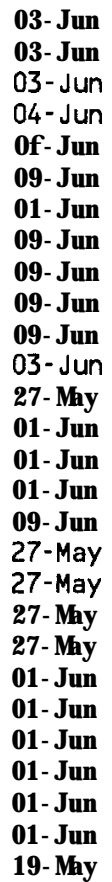 & $\begin{array}{r}82 \\
65 \\
90 \\
107 \\
82 \\
74 \\
85 \\
82 \\
87 \\
90 \\
81 \\
70 \\
80 \\
80 \\
77 \\
72 \\
78 \\
74 \\
70 \\
72 \\
75 \\
75 \\
80 \\
78 \\
77 \\
80 \\
73 \\
71\end{array}$ & $\begin{array}{r}6.3 \\
0 \\
0 \\
14.5 \\
6.4 \\
4.8 \\
0 \\
5.6 \\
6.8 \\
8.9 \\
5.6 \\
3.9 \\
0 \\
0 \\
0 \\
0 \\
5 \\
4.3 \\
3.7 \\
4.2 \\
3.6 \\
5.7 \\
0 \\
0 \\
0 \\
0 \\
3.7\end{array}$ & $\begin{array}{l}274 \\
282 \\
282 \\
251 \\
242 \\
250 \\
262 \\
250 \\
250 \\
250 \\
242 \\
274 \\
282 \\
262 \\
262 \\
262 \\
242 \\
262 \\
274 \\
282 \\
282 \\
262 \\
262 \\
262 \\
262 \\
262 \\
262 \\
282\end{array}$ & 04-J un & 84 & 6 & 262 & $\begin{array}{r}8 \\
7 \\
20 \\
22 \\
13 \\
7 \\
5 \\
7 \\
7 \\
7 \\
20 \\
7 \\
8 \\
5 \\
5 \\
5 \\
7 \\
14 \\
8 \\
8 \\
13 \\
5 \\
5 \\
5 \\
5 \\
5 \\
5 \\
5\end{array}$ & \\
\hline
\end{tabular}




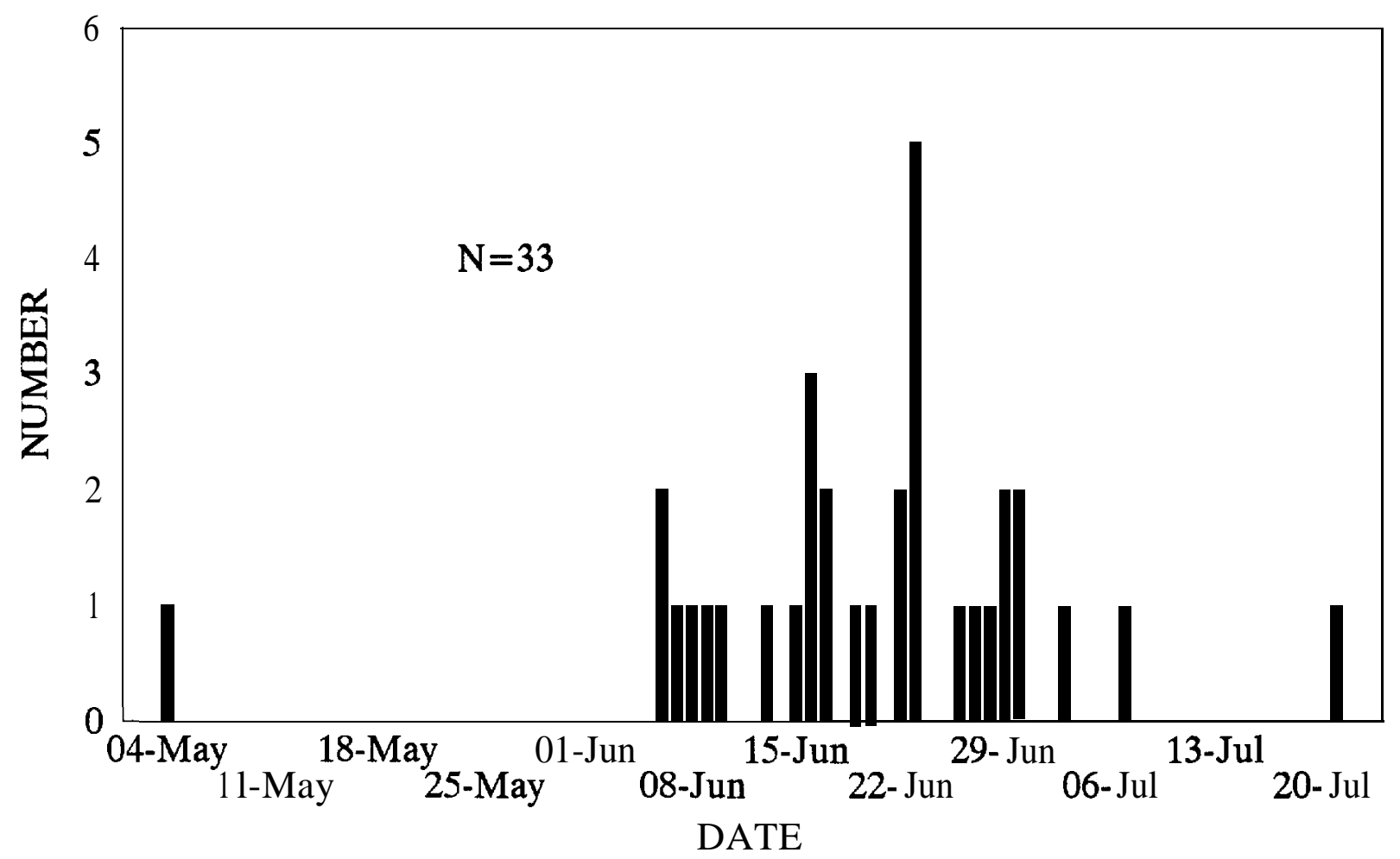

Figure 15.-PIT-tag detection numbers for fall chinook salmon juveniles released in the Snake River in 1992.

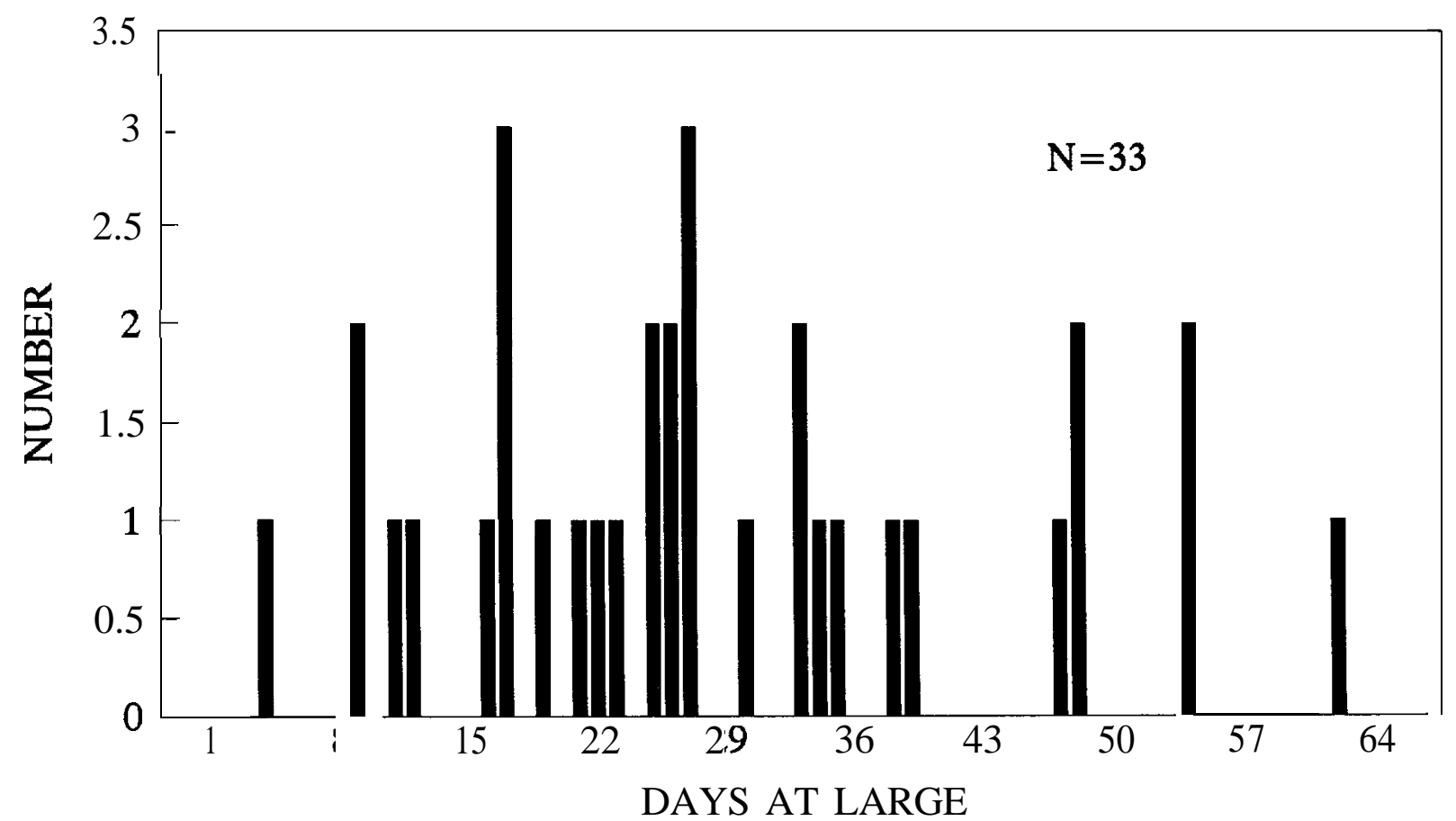

Figure 16.-Number of days PIT-tagged Snake River fall chinook salmon juveniles were at large in 1992 before detection at Lower Granite Dam. 


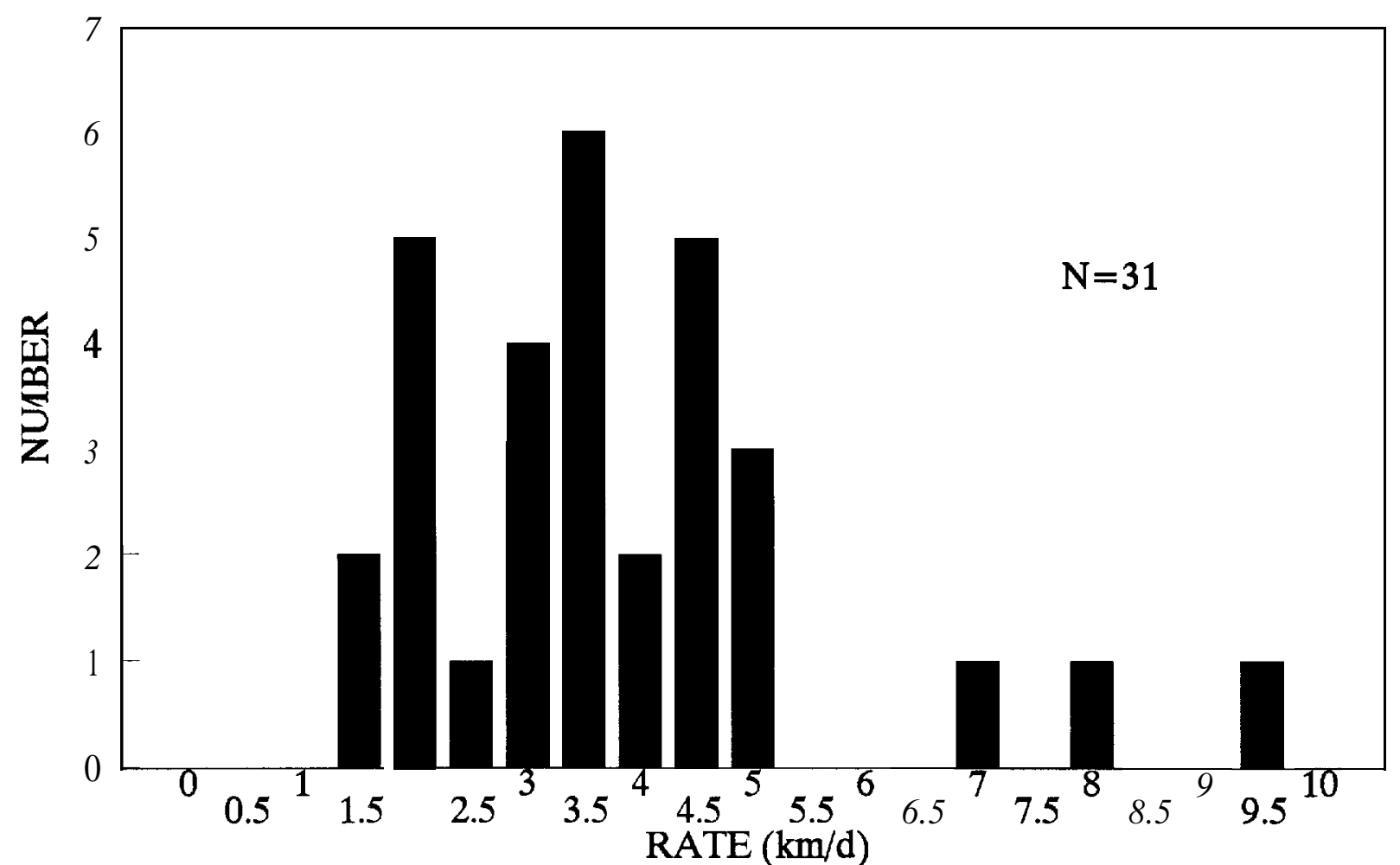

Figure 17.-Emigration rates of PIT-tagged Snake River fall chinook salmon detected at Lower Granite Dam in 1992. Note that two outliers were removed from this figure after regression analysis.

Influence of Flow, Temperature, and Size on Emigration Rate

Pearson correlations (SYSTAT 1990) indicated there was collinearity between emigration flow and emigration temperature (Pearson Correlation $=-0.885$; Table 6). After removing emigration temperature from the analysis, $72 \%$ of the variability in emigration rate in 1992 could be explained by emigration flow, release temperature, and release size (Table 7).

The relation of emigration rate to the emigration flow, release temperature, and release size for 1992 was:

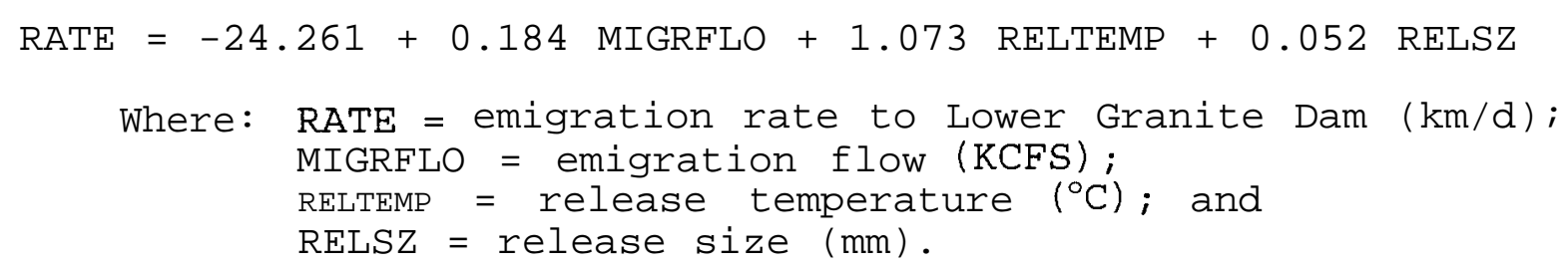


Table 6.-Pearson correlation matrix for the emigration rate analysis of Snake River fall chinook salmon juveniles, 1992 .

\begin{tabular}{lrrrr}
\hline & MIGRFLOW & MIGRTEMP & RELTEMP & RELSZ \\
MIGRFLO & 1.000 & & & \\
MIGRTEMP & -0.885 & 1.000 & & \\
RELTEMP & -0.614 & 0.609 & 1.000 & 1.000 \\
RELSZ & -0.200 & 0.161 & 0.502 & \\
\hline
\end{tabular}

Table 7.-SYSTAT multiple regression output (forward stepwise) for relation among emigration rate (MIGRRATE), emigration flow (MIGRFLO), release temperature (RELTEMP), and release size (RELSZ). Data were collected by PIT tagging Snake River fall chinook salmon juveniles, 1992.

DEP VAR=RATE $\mathrm{N}=31$ MULTPL $\mathrm{R}=0.845$ SQUARED MULTPL $\mathrm{R}=0.715$ ADJUSTED SQUARED MULTPL $\mathrm{R}=.683$ STD ERROR OF ESTIMATE=1.033

VARIABLE COEF. STD ERROR STD COEF TOLERANCE T P(2 TAIL)

$\begin{array}{lrrrrrr}\text { CONSTANT } & -24.261 & 3.598 & 0.000 & . & -6.743 & 0.000 \\ \text { MIGRFLO } & 0.184 & 0.035 & 0.689 & 0.607 & 5.217 & 0.000 \\ \text { RELTEMP } & 1.073 & 0.191 & 0.839 & 0.473 & 5.609 & 0.000 \\ \text { RELSZ } & 0.052 & 0.022 & 0.288 & 0.729 & 2.393 & 0.024\end{array}$

ANALYSIS OF VARIANCE

SOURCE SUM-OF-SQUARES DF MEAN-SQUARE F-RATIO P

$\begin{array}{lrrrrr}\text { REGRESSION } & 72.144 & 3 & 24.048 & 22.540 & 0.000 \\ \text { RESIDUAL } & 28.806 & 27 & 1.067 & & \end{array}$

Furthermore, from data in Table 7, we concluded that the 1992 response in emigration rate was higher with increases in release temperature (standardized coefficient $=0.839$ ) than with increases in emigration flow (standardized coefficient $=0.689$ ), or release size (standardized coefficient $=0.288$ ).

Using 1992 averages for release size, release temperature, and emigration flow, this relation predicts that a $77 \mathrm{~mm}$ fall chinook salmon, released in $15.4^{\circ} \mathrm{C}$ nearshore water, would have emigrated $5.5 \mathrm{~km} / \mathrm{d}$ under flows of $50 \mathrm{KCFS}$ compared to $3.6 \mathrm{~km} / \mathrm{d}$ under the $39.9 \mathrm{KCFS}$ flow that actually occurred (53\% faster under 50 KCFS; Figure 18). 


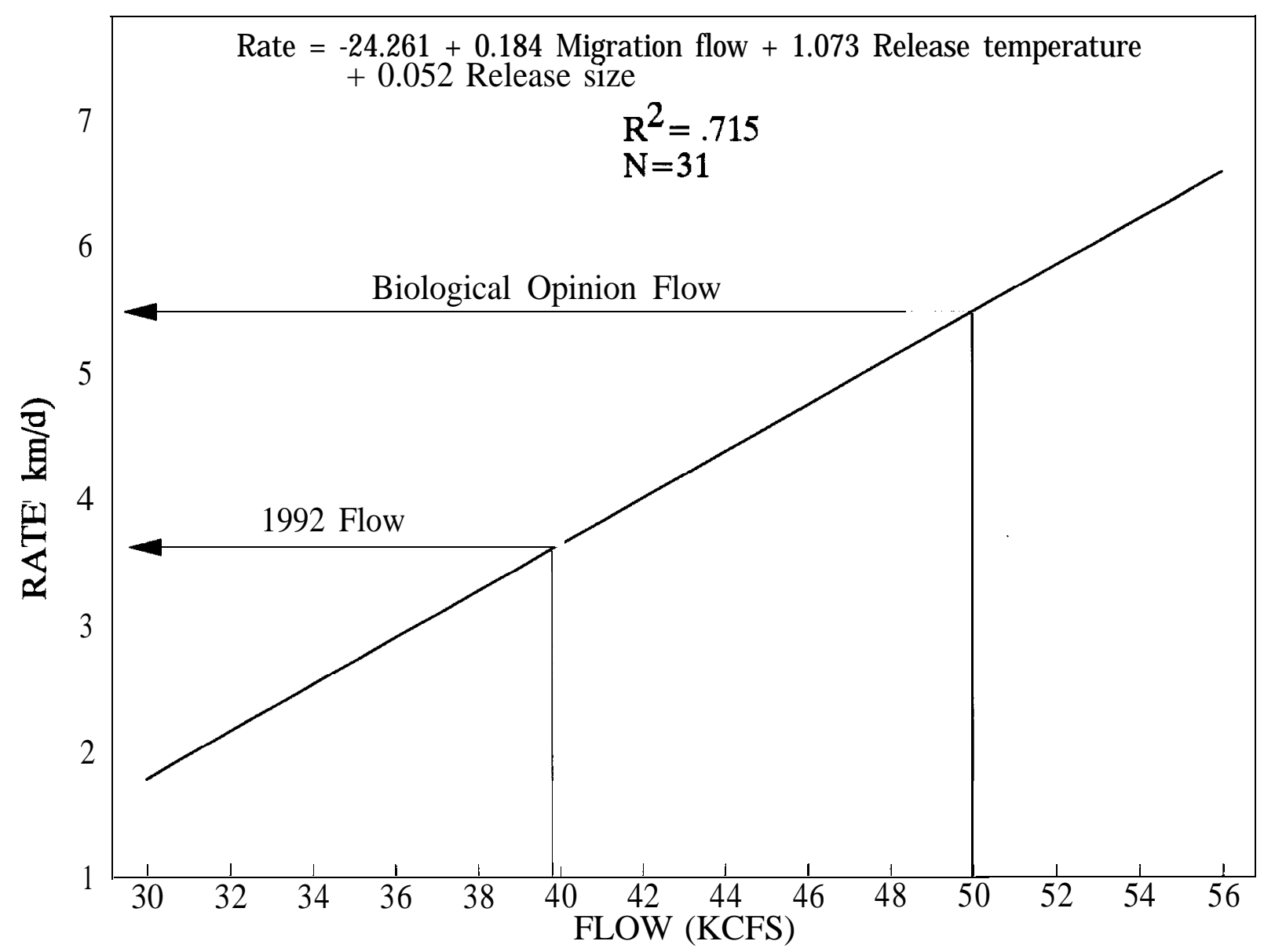

Figure 18. Predicted emigration rates for a $77 \mathrm{~mm}$ PIT-tagged fall chinook salmon released in 15.4 degrees Celsius water under the average 1992 flow conditions at Lower Granite Dam and under the Biological Opinion flow fo $50 \mathrm{KCFS}$. 


\section{Discussion}

Differences in fall chinook salmon early life history were documented between 1991 and 1992. Peak fall chinook salmon fry emergence in 1992 was back calculated to late April, about $30 \mathrm{~d}$ earlier than in 1991 (Connor et al. 1993). After emerging in 1992, fall chinook salmon reared in nearshore areas from midMarch to early June with a mid-May peak based on CPUE calculated from systematic samples. In 1991, PIT-tagged fall chinook salmon rearing in near-shore areas appeared to have begun in May and extended through mid-July (Connor et al. 1993). The highest 1991 catch of fall chinook salmon occurred at RK 242 about $3 \mathrm{~km}$ below Big Bench Point where about 43\% of all redds were counted in brood year 1991 (Garcia et al. in this report). We had the highest CPUE at RK 282 in 1992, while most fall chinook salmon spawning in brood year 1992 was documented below this site (Garcia et al. in this report). High CPUE at RK 282 may have been the result of fish concentrating in one area since rearing habitat may be less available in the higher gradient reaches above the mouth of the Grande Ronde River. Some fall chinook salmon juveniles in the snake River showed fidelity to individual rearing areas prior to emigration in both 1991 and 1992. In 1991, about 8\% (53 of 650) of PIT-tagged fall chinook salmon were recaptured within 1 to 21 d after tagging (Connor et al. 1993). Only one of the tagged fall chinook salmon was recaptured away from the original tagging site. In 1992, we recaptured about 7\% (69 of 947) of the fall chinook salmon tagged, and seven of the fish had moved downstream. The differences in fall chinook salmon early life history between 1991 and 1992 were undoubtedly related to flows and water temperatures, however an in depth analysis of this topic is beyond the scope of this annual report.

Fall chinook salmon arrival at Lower Granite Dam was a summer event in 1992 as in most years, but the arrival pattern was truncated. The 1991 detection pattern of PIT-tagged fall chinook salmon at Lower Granite Dam was protracted, extending into early september, while no PIT-tagged fall chinook salmon were detected after 20 July in 1992. The truncation of the 1992 PIT-tag detection pattern may have been due to decreased survival of later emigrating PIT-tagged salmon, poor fish guidance efficiency at Lower Granite Dam, or a combination of both. It is likely that any of these explanations would be correlated to the relatively lower flows and warmer water temperatures of 1992 .

Fall chinook salmon emigration rate was faster in 1992 (3.6 $+1.8 \mathrm{~km} / \mathrm{d})$ than in $1991(2.3+1.0 \mathrm{~km} / \mathrm{d})$, even after we adjusted the 1991 data set for a minimum emigration size (Connor et al. 1993). At first glance, we thought that faster 1992 emigration rates may have been due to the truncated detection pattern of PIT-tagged fall chinook salm.un at Lower Granite Dam, since the' 1992 data set lacked late arriving PIT-tagged emigrants which can 
have slower than average emigration rates. However, the mean emigration rate of the first 50\% of PIT-tagged fall chinook salmon in $1991(2.9 \pm 0.9 \mathrm{~km} / \mathrm{d})$ was still slower than the overall 1992 rate. We concluded that fall chinook salmon emigrated faster in 1992 than in 1991.

Faster emigration rates in 1992 may be explained by differences in release water temperature and flow between years. Water temperature increased and flow decreased earlier in 1992 than in 1991. Fall chinook salmon emigration behavior evolved under the descending limb of summer flows when water is warming rapidly, so faster emigration rates under less optimum rearing conditions would be a survival adaptation. In the case of summer emigrants, the pattern of change in temperature and flow may be as significant a determinant of emigration rate, as a given temperature or flow volume.

The 1992 emigration rate analysis indicated that of the variables tested, release temperature had the greatest effect on emigration rate of PIT-tagged fall chinook salmon followed closely by flow. Conversely, flow had greater effect than release temperature in 1991. The role of fall chinook salmon release size was also different between 1991 and 1992. Release size accounted for 53\% of the variability in emigration rate in the 1991 data and by adjusting the data set to a minimum emigration size we were better able to relate emigration rate to emigration flow and release temperature. Therefore, we theorized that in 1991 fall chinook salmon juveniles did not actively migrate until they grew to a minimum size (Connor et al. 1993). Release size had a positive significant effect on 1992 emigration rate $\left(r^{2}=0.32 ; p=0.001\right)$, but its influence was lowest of the three independent variables tested. We concluded that the 1992 pattern of an early decrease in flow accompanied by the rapid rise in temperature may have triggered fall chinook salmon emigration with somewhat less dependence on size.

Prior to 1991 there was no summer flow augmentation for natural Snake River fall chinook salmon emigration (Connor et al. 1992). We used our regression model to assess the benefits of increasing flow over fall chinook salmon emigration in 1992 . Our model predicted that if the $50 \mathrm{KCFS}$ flow recommended by the NMFS's Biological Opinion (1993) was implemented in 1992, the average fall chinook salmon emigrant would have spent less time reaching Lower Granite Dam.

In summary, we seined 1,309 fall chinook salmon in systematic samples in 1992. Estimated fall chinook salmon fry emergence ranged from 18 March to 25 May with a 25 April peak. Weekly CPUE of fall chinook averaged 2.6 (range 0.3-8.5) and peaked on 20 May. We PIT tagged and released 1,100 chinook salmon juveniles of which 947 were considered as fall chinook salmon (87\%) on the basis of post season race separation. We 
tagged fall chinook salmon in the Snake River from 14 April

through 10 June with a 27 May peak. About 7\% of all tagged fall

chinook salmon were recaptured by seine; most at the original

site of tagging. Mean emigration rate from release sites in

Hells Canyon to Lower Granite Dam was $3.6 \mathrm{~km} / \mathrm{d}$ with peak and median dates of passage on 23 and 22 June, respectively. Using multilinear regression we estimated that emigration rate was significantly influenced by temperature, flow, and fish size. It is important to realize that the low population level of Snake River fall chinook salmon dictated small sample sizes for analyses. These preliminary analyses and interpretations will be refined with the collection of additional data in the future. 


\section{References}

Abbersold, T.D., G.A. Winans, D.J. Tel, G.B. Milner, and F.N. Utter. 1987. Manual for starch gel electrophoresis: A method for the detection of genetic variation. Report No 61 . National Marine Fisheries Service, Seattle, Washington.

Arnsberg, B.D., W.P. Connor, and E. Connor. 1992. Mainstem Clearwater River study: Assessment for salmonid spawning, incubation, and rearing. Final Report by the Nez Perce Tribe, Contract DE-AI79-87-BP37474 to Bonneville Power Administration, Portland, Oregon.

Chapman D., A. Giorgi, M. Hill, A. Maule, S. McCutcheon, D. Park, W. Platts, K. Pratt, J. Seeb, L. Seeb, and F. Utter. 1991. Status of Snake River chinook salmon. Report to the Pacific Northwest Utilities Conference Committee by Don Chapman Consultants, Inc., Boise, Idaho.

Connor, W.P., H.L. Burge, and R. Bugert. 1992. Outmigration timing of natural and hatchery snake River fall chinook salmon. Proceedings of the American Fisheries Society chinook salmon smolt survival workshop. Published by the Idaho Chapter of the American Fisheries Society and the Idaho Water Resource Institute, Moscow. Idaho.

Connor, W.P., H.L. Burge, and W.H. Miller. 1993. Rearing and emigration of naturally produced Snake River fall chinook salmon juveniles. Pages 86-116 in Rondorf, D. and W.H. Miller, editors. Identification of the spawning, rearing, and migratory requirements of fall chinook salmon in the Columbia River Basin. Annual Progress Report by the United States Fish and Wildlife Service, Contract DE-AI7991BP21708, to Bonneville Power Administration, Portland, Oregon.

Jerald, A. 1983. Age determination. Pages 301-324 in Nielsen, L.A. and D.L. Johnson, editors. Fisheries Techniques. American Fisheries Society, Bethesda, Maryland.

McCann, J.A., H.L. Burge, and W.P. Connor. 1993. Evaluation of PIT tagging of subyearling chinook salmon. Pages 63-85 in Rondorf, D. and W.H. Miller, editors. Identification of the spawning, rearing, and migratory requirements of fall chinook salmon in the Columbia River Basin. Annual Progress Report by the United States Fish and Wildlife Service, Contract DE-AI79-91BP21708, to Bonneville Power Administration, Portland, Oregon. 
National Marine Fisheries Service. 1993. Biological opinion on 1993 operation of the federal Columbia River power system. United States Department of Commerce, Silver Spring, Maryland.

PIT Tag Work Group. 1991. PIT tag specification document. Columbia River Basin PIT Tag Information System Data Source Input Specifications. Portland, Oregon.

Prentice, E.F., T.A. Flagg, and C.S. McCutcheon. 1990a. Feasibility of using implantable passive integrated transponders (PIT) tags in salmonids. American Fisheries Society Symposium 7:317-322.

Prentice, E.F., T.A. Flagg, C.S. McCutcheon, and D.F. Brastow. 1990b. PIT-tag monitoring systems for hydroelectric dams and fish hatcheries. American Fisheries Society Symposium 7:323334 .

SYSTAT. 1990. SYSTAT for DOS, version 5.02. SYSTAT, Inc., Evanston, Ilinois.

United States Fish and Wildlife Service. 1988. Endangered Species Act of 1973 as amended through the 100th Congress. United States Department of the Interior, Washington, D.C. 
CHAPTER SIX

Nearshore Habitat Use by Subyearling Chinook Salmon
in the Columbia and Snake Rivers by

L.O. Key, J.A. Jackson, C.R. Sprague, and E.E. Kofoot National Biological Survey

Columbia River Research Laboratory

Cook, Washington 98605, USA 


\section{Introduction}

Currently, little published information exists on habitat requirements for subyearling fall chinook salmon Oncorhynchus tshawytscha rearing in the Columbia and Snake rivers. Subyearling chinook salmon have been reported in shoreline areas of the snake (Mains and Smith 1964) and Columbia rivers (Mains and Smith 1964; Becker 1973; Dauble et al. 1980; Dauble et al. 1989) and in backwater nearshore areas of the Columbia and Snake river reservoirs (Zimmerman and Rasmussen 1981; Bennett et al. 1990, 1991, 1993). Subyearling chinook salmon may reside along river margins because maximum growth is achieved through the interaction of food resources, velocity, and temperature (Becker 1973). The role of these variables in the dispersal, rearing, and migratory stages of subyearling chinook salmon is unknown, but needs to be determined to effectively conserve and enhance fall chinook salmon populations. Furthermore, such information is necessary to protect important rearing habitats in future proposals to modify reservoir and riverine habitats by dredging, filling, bank stabilization, flow management, and water diversion.

The goal of this study is to identify and describe the characteristics of rearing habitats used by naturally produced subyearling chinook salmon in riverine reaches and in main-stem reservoirs. Preliminary results described in this report were obtained during the first year of a five-year study .

\section{Study Area}

The 1992 study area included two reaches in the Columbia River from river kilometer (RK) 508 to RK 530 in McNary Reservoir and from RK 563 to RK 581 in the Hanford Reach (Figure 1). The Snake River was sampled between RK 227 and RK 358 (see Connor et al. this report for map). River kilometer information was obtained from the National Oceanic and Atmospheric Administration for McNary Reservoir, from the United States Geological Survey (USGS) 7.5 minute topographic maps for the Hanford Reach, and from the U.S. Army Corps of Engineers (COE) navigation charts for the Snake River.

\section{Methods}

Methods for the collection and handling of fish captured in the Snake River are described by Connor et al. (in this report). The methods outlined in this chapter describe the procedure for site selection, capture and handling of fish in the columbia River reaches. Habitat variables were measured in the same manner for all reaches except where noted. 


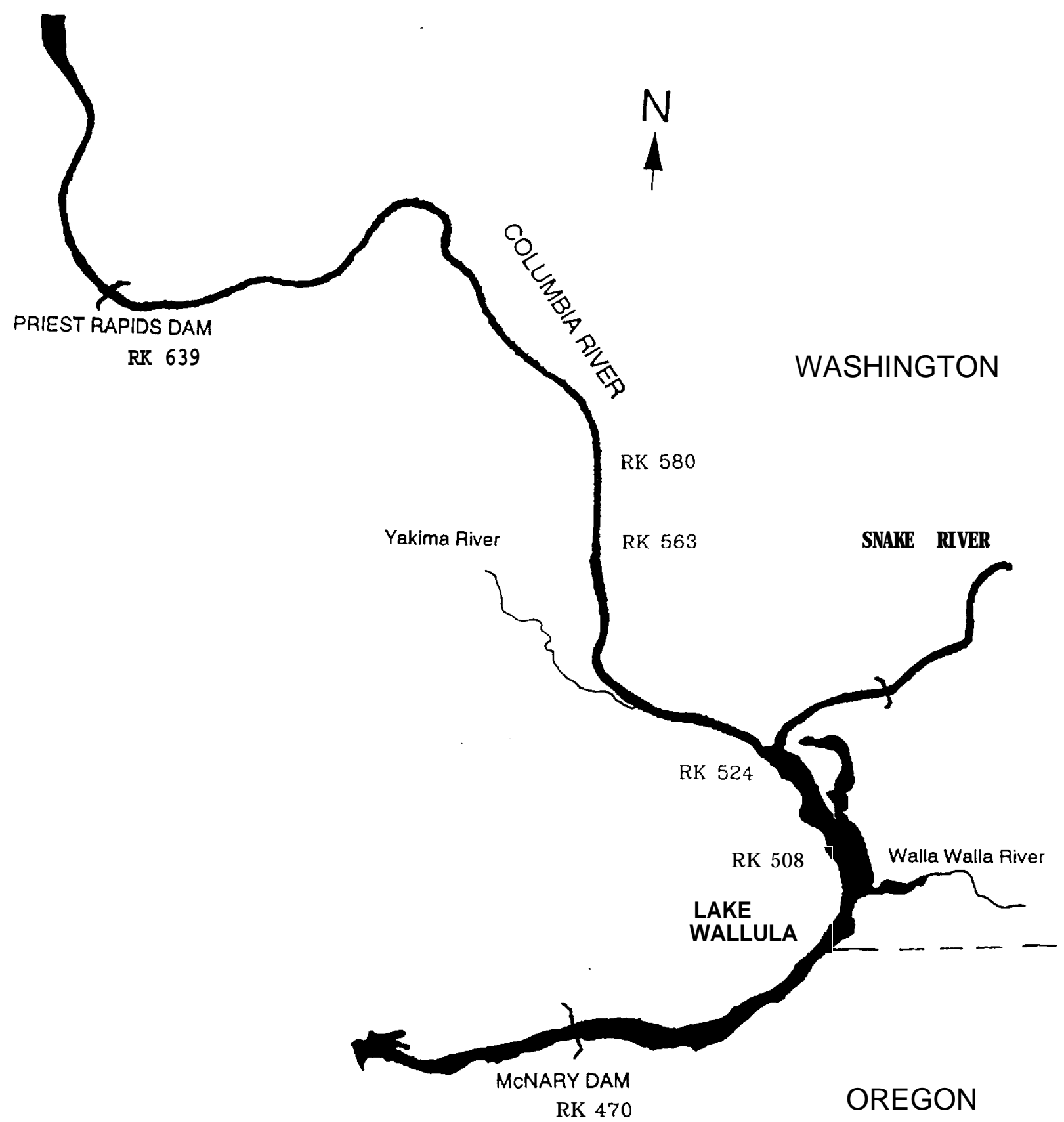

Figure 1.- Map showing the location of McNary Reservoir and Hanford Reach habitat sampling areas. Sampling areas in McNary Reservoir extends from RK 508 upstream to RK 523 and in the Hanford Reach from RK 563 to RK 580 . 
The sites selected were conducive to beach seining and represent combinations of habitat variables available to subyearling chinook salmon. Sites were selected on both banks of the river channel and on side channels. Both linear and complex shorelines were selected in backwater and main channel areas.

\section{All sites in McNary Reservoir (36) and the Hanford Reach} (16) were identified by a stake placed above the high water mark. This ensured that the same location would be sampled throughout the season and allowed for measurement of changes in the water elevation at each site. Once all sites were selected, blocks containing six or more sites were established and the sampling order randomized within each block. A single seine haul was made at each site in McNary and Hanford reaches during each week of sampling. All sites were sampled during daylight hours. Sites in McNary and Hanford reaches were sampled from May to August.

\section{Seining}

The beach seine used in McNary Reservoir was $30.5 \mathrm{~m}$ x $2.4 \mathrm{~m}$ with $0.48 \mathrm{~cm}$ mesh, $2.4 \mathrm{~m}^{3}$ bag and $15.2 \mathrm{~m}$ leads. A polypropylene rope was wrapped around the leadline to increase its diameter and reduce the incidence of snagging and collecting large substrate. The seine was set from the bow of a $5.5 \mathrm{~m}$ boat by backing $15.2 \mathrm{~m}$ from shore and then setting the seine parallel to the shoreline in an upstream direction. Once the net was set, both ends of the seine were pulled simultaneously to the shore by the leads. This sampled an area of about $460 \mathrm{~m}^{2}$ at each site in McNary Reservoir. The beach seine used in the Hanford Reach was of the same design as used in McNary Reservoir except it was $22.9 \mathrm{~m}$ long and sampled an area of about $345 \mathrm{~m}^{2}$.

\section{Catch}

Fish caught in each seine haul were processed immediately to minimize stress. If more than 40 subyearling chinook salmon were captured, a subsample of approximately 30 were randomly removed and processed. The subsample was anesthetized with $26 \mathrm{mg}$ per liter of tricaine methanesulfonate (MS-222), fork lengths (L) measured to the nearest millimeter, and weights (W) were recorded to the nearest $0.1 \mathrm{~g}$. Remaining salmonids and incidental fish caught were identified to the lowest taxonomic group possible, enumerated, and released. Based on length frequency information obtained from each week of sampling, subyearling chinook salmon were separated from yearling chinook salmon. Mean catch and mean length of subyearling chinook salmon were computed per seine haul for each week of sampling. All hauls were used to compute means in the Columbia River reaches. Only hauls made at 10 sites consistently sampled every week beginning the week of 20 April were used to compute mean catch in the snake River. Length and weight data obtained from subyearling chinook salmon were plotted and a curve fitted by the power equation, $W=a L^{b}$ (Ricker 1958). 
Because all habitat seining activities were performed during daylight hours, a pilot diel study was conducted to determine if subyearling chinook salmon catch remained constant in the shoreline areas during day and night. Sixteen sites along a shoreline on Foundation Island (RK 518-518.5) in McNary Reservoir were randomly sampled. A total of 71 beach seine hauls were made over three days in mid June. Catch and light were analyzed to determine whether they were significantly correlated ( $P$ s 0.05 ). Mean catches were calculated and grouped into five light categories, then statistically analyzed using analysis of variance and Tukey's studentized range test (SAS Institute 1988). Differences were considered statistically significant when $P \leq$ 0.05 .

\section{Habitat Measures}

Habitat variables that fluctuated on a daily basis were measured for each seine haul. Light and turbidity were measured before each net set. Light was measured above the water surface and $0.5 \mathrm{~m}$ below the water surface using an International Light $1400 \mathrm{~A}$ light meter.. Turbidity of water collected $15 \mathrm{~cm}$ below the surface was measured with $a$ Hach $2100 \mathrm{P}$ turbidity meter. After seining each site, distance from the stake to the waterline was measured. The midpoint of the seine site was determined by measuring half the seine length upstream from the stake. At midpoint and $1 \mathrm{~m}$ from the shoreline, water temperature was measured to $0.1^{\circ} \mathrm{C}$. Water velocity was measured at the midpoint $7.6 \mathrm{~m}$ and $15.2 \mathrm{~m}$ from the shoreline using a Swoffer Model 2100 or Marsh McBirney Model 2000 velocity meter. Temperature and dissolved oxygen were measured at the midpoint $15.2 \mathrm{~m}$ from the shoreline and at $1 \mathrm{~m}$ below the surface using a YSI Model 59 dissolved oxygen meter.

Thermographs were set to record water temperatures at one hour intervals in a main channel (RK 516.0), side channel (RK 512.0), and backwater area (RK 510.7) of McNary Reservoir. A single thermograph was set in a main channel area of the Hanford Reach (RK 561.8). Thermographs were set $15 \mathrm{~m}$ from the shoreline in approximately $2-3 \mathrm{~m}$ of water.

The physical characteristics of the seining sites were surveyed after completing beach seining. Depth, substrate, embeddedness and vegetation were mapped for McNary Reservoir and Hanford Reach sites. An electronic total station was used to measure distances to points where habitat characteristics were measured within the beach seine sites. At each point the substrate was visually assessed and assigned a code according to a Wentworth classification modified from Orth (1983).

Descriptions for visually evaluating substrate embeddedness were obtained from Platts et al. (1983). Aquatic vegetation was assessed for species, numbers of plants per meter and height. Habitat and positional information for each point were entered 
into a spreadsheet and transferred to a raster based geographic information system (GIS). In GIS, habitat was mapped using $1 \mathrm{~m}^{2}$ cells. Relative water elevation for each seine haul was calculated from the stake distance. Elevation was used to determine the nearest wetted row of cells which became the beginning point of the beach seine. Once the shoreline point of each beach seine haul was known, the surveyed habitat variables were estimated using the GIS record.

Results

\section{Catch of Subyearling Chinook Salmon}

During the habitat study, a total of 18,858 subyearling chinook salmon were captured in McNary Reservoir; 2, 972 were caught in the Hanford Reach; and 1,322 were caught in the Snake River. Connor et al. (this report) estimated 1,309 of the subyearlings caught in the snake River were of the fall chinook salmon race using a post season size limit criteria. Subyearling chinook salmon made up 79\% of the combined salmonid and incidental catch in McNary Reservoir and 63\% of the combined catch in the Hanford Reach from May through August. Incidental fish caught in McNary Reservoir and the Hanford Reach are reported in Appendix 6.

A total of 169 beach seine hauls in McNary Reservoir, 73 hauls in the Hanford Reach and 272 hauls in the Snake River were made during the habitat study. Success in capturing one or more subyearling chinook salmon in a haul varied between reaches. In McNary Reservoir 61\% of the hauls succeeded in capturing subyearlings (102 hauls), in the Hanford Reach 68\% succeeded (50 hauls), and in the snake River 50\% succeeded (136 hauls).

The mean weekly catch per seine haul for McNary Reservoir, Hanford Reach, and the Snake River peaked in May then decreased throughout the summer (Figure 2; Appendix 7). The highest mean number of subyearling chinook salmon captured per seine haul (682) occurred in McNary Reservoir during the week of 12 May 1992. Catches were lower in the Hanford Reach than in McNary Reservoir during all weeks sampled with a peak of 153 juvenile chinook salmon captured during the week of 25 May. Subyearling chinook salmon were not captured in nearshore areas in August in either McNary Reservoir or Hanford Reaches. Peak mean catch of 159 subyearling chinook salmon occurred during the week of 3 May in the Snake River.

Subyearling chinook salmon in the snake River maintained the highest mean fork length for every week sampled in comparison to Columbia River reaches (Figure 3; Appendix 8). Mean fork length of subyearling chinook salmon in McNary Reservoir was consistently higher than mean fork length in the Hanford Reach. 

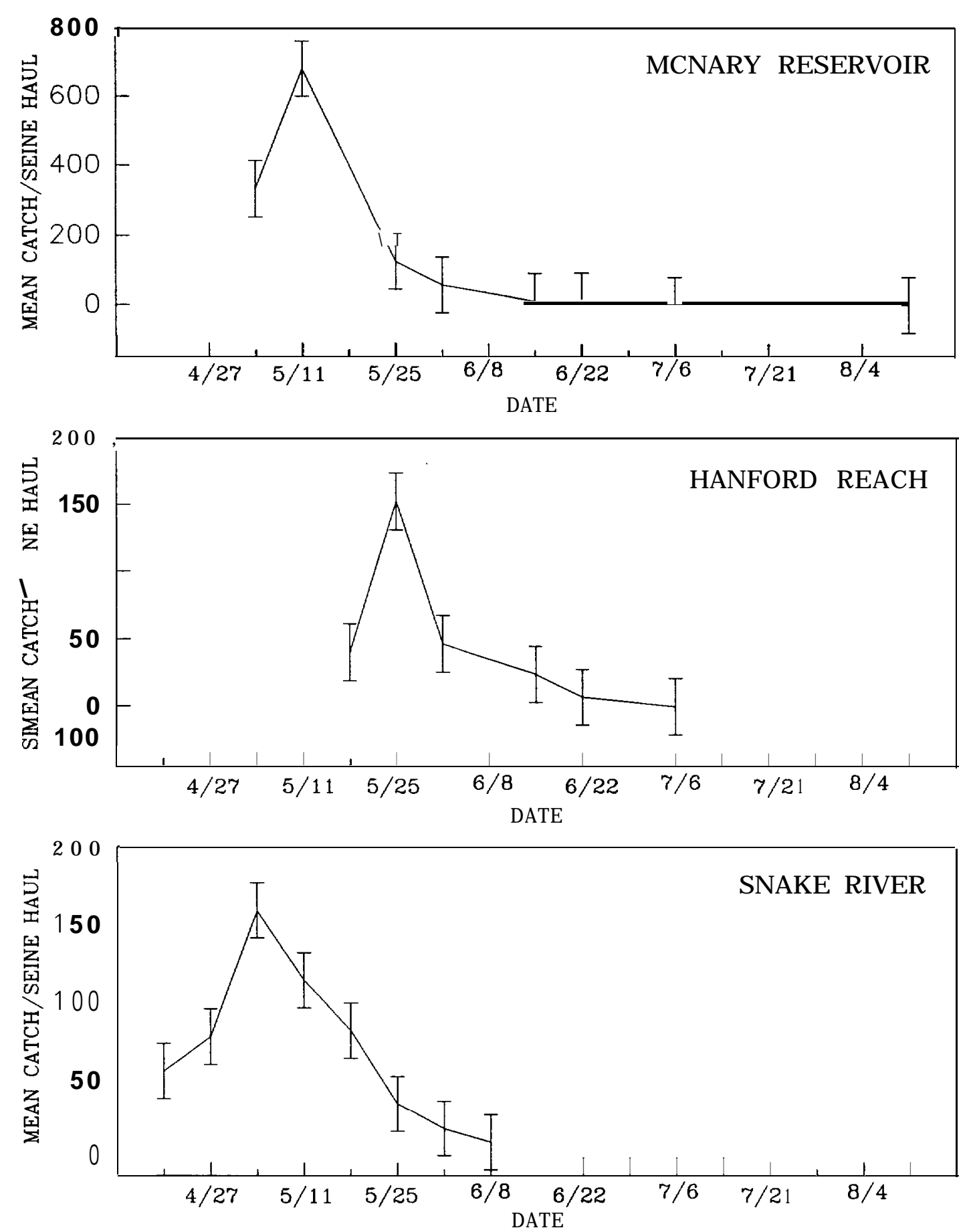

Figure 2 . Mean catch ( \pm se) of subyearling chinook salmon caught by beach seine during one week sampling intervals in McNary Reservoir and the Hanford Reach of the Columbia River, Washington and in the Snake River, Idaho, Oregon, and Washington. 


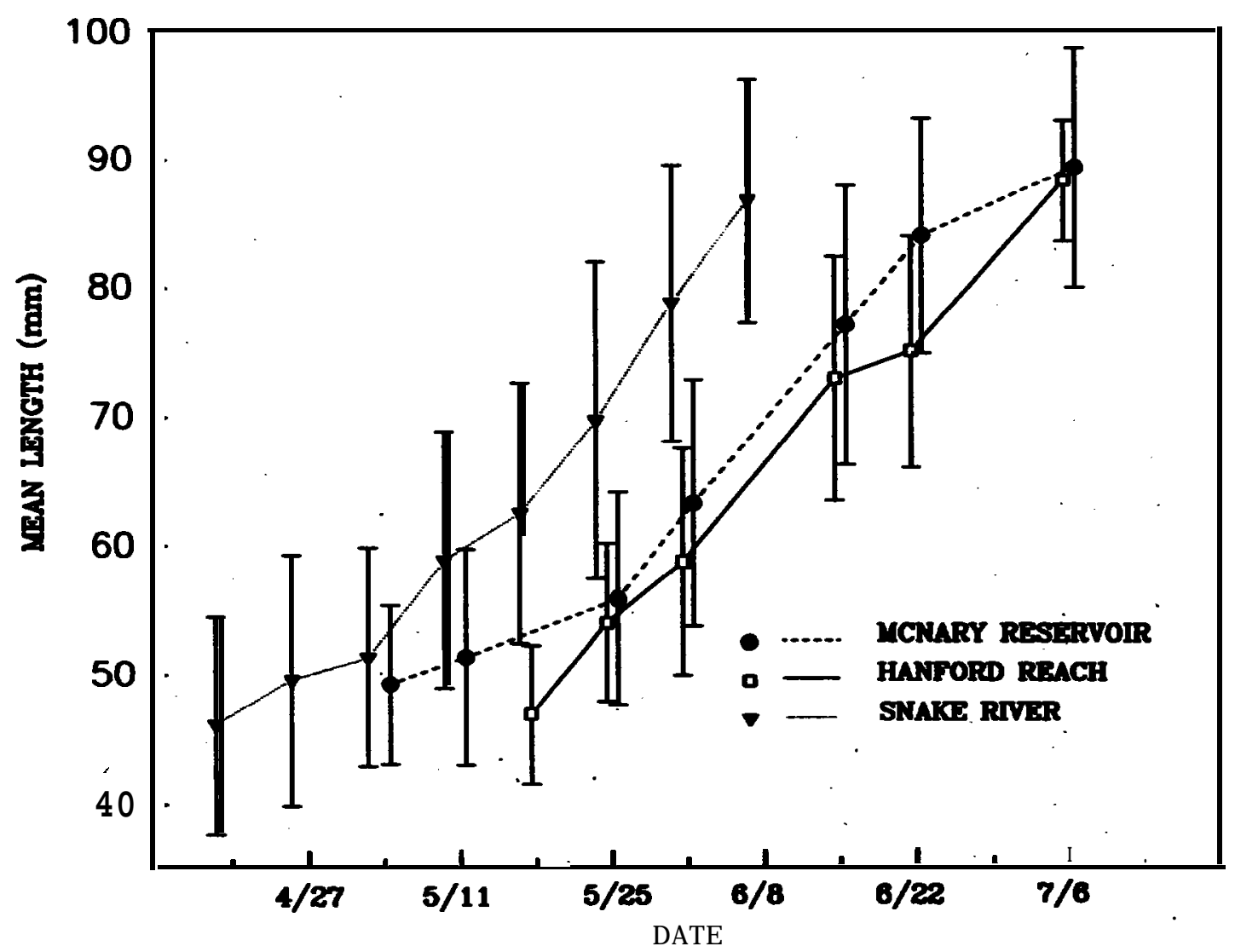

Figure 3.- Hean fork length (t sd) of subyearling chinook salmon caught in Hollary Reservoir and the Hanford Reach of the Columbia River, Washington and in the Snake River, Idaho, Oregon, and Washington. 
The length-weight curves for subyearling chinook salmon were similar for the two riverine reaches (Figure 4). The curve for McNary Reservoir had a larger exponent value indicating higher measured weight for a given length of subyearling chinook salmon.

\section{Diel Catch}

A total of 10,511 subyearling chinook salmon were caught during the diel study. Low numbers of subyearling chinook salmon were caught during the night (Figure 5). Catch increased immediately following sunrise (0515 hour) and decreased at sunset (2045 hour). Catch was significantly correlated with light ( $r=$ 0.52) (Figure 5). The hypothesis that mean catch for night and day categories was the same was rejected. Mean catch from day categories were not significantly different from each other nor were night categories significantly different from each other. Since no significant difference was found between the morning, midday and evening periods, the habitat data collected during these day periods were combined for analysis.

\section{Habitat}

For each seine haul, a GIS mapping procedure was used to produce a map containing defined strata for the surveyed habitat variables (Figure 6). Catch of subyearling chinook salmon was compared to the effort associated with various depths, velocities, temperatures, and substrates.

Most effort in McNary Reservoir was expended in shallow water sites $(<1.5 \mathrm{~m})$ and low water velocity ( $<0.05 \mathrm{~m} / \mathrm{s}$ ) (Figures 7 and 8). Few subyearlings were caught in sites where water depth $15.2 \mathrm{~m}$ from the shore was $<0.5 \mathrm{~m}$. Highest mean catch per seine haul was observed in sites with depths $0.5-1 \mathrm{~m}$ at $7.6 \mathrm{~m}$ from the shoreline, and $0.75-1.75 \mathrm{~m}$ at $15.2 \mathrm{~m}$ from the shoreline. No relationship could be discerned between velocity and mean catch over the range in velocities presented. Daily temperature fluctuations measured by thermograph in nearshore areas had a range of $1.5^{\circ} \mathrm{C}$ (Figure 9). Highest mean catch per seine haul occurred at temperatures between $13.0-14.9^{\circ} \mathrm{C}$ at both $1 \mathrm{~m}$ and 15.2 $\mathrm{m}$ from the shore (Figure 10). No subyearling chinook salmon were caught when temperatures exceeded $26.7^{\circ} \mathrm{C}$ at $1 \mathrm{~m}$ from the shoreline or $21.9^{\circ} \mathrm{C}$ at $15.2 \mathrm{~m}$ from the shoreline. Catch of subyearling chinook salmon was not related to percent of fine substrate (Figure 11).

In the Hanford Reach, seining effort was distributed more evenly for depth, but no trends in the average catch per seine haul were obvious (Figure 12). Highest effort was expended in low velocities $(<0.05 \mathrm{~m} / \mathrm{s})$ at $7.6 \mathrm{~m}$ and $15.2 \mathrm{~m}$ from shore and resulted in the highest catch of subyearling chinook salmon

(Figure 13). No relationship could be discerned between velocity and mean catch. Daily temperature fluctuations measured by 


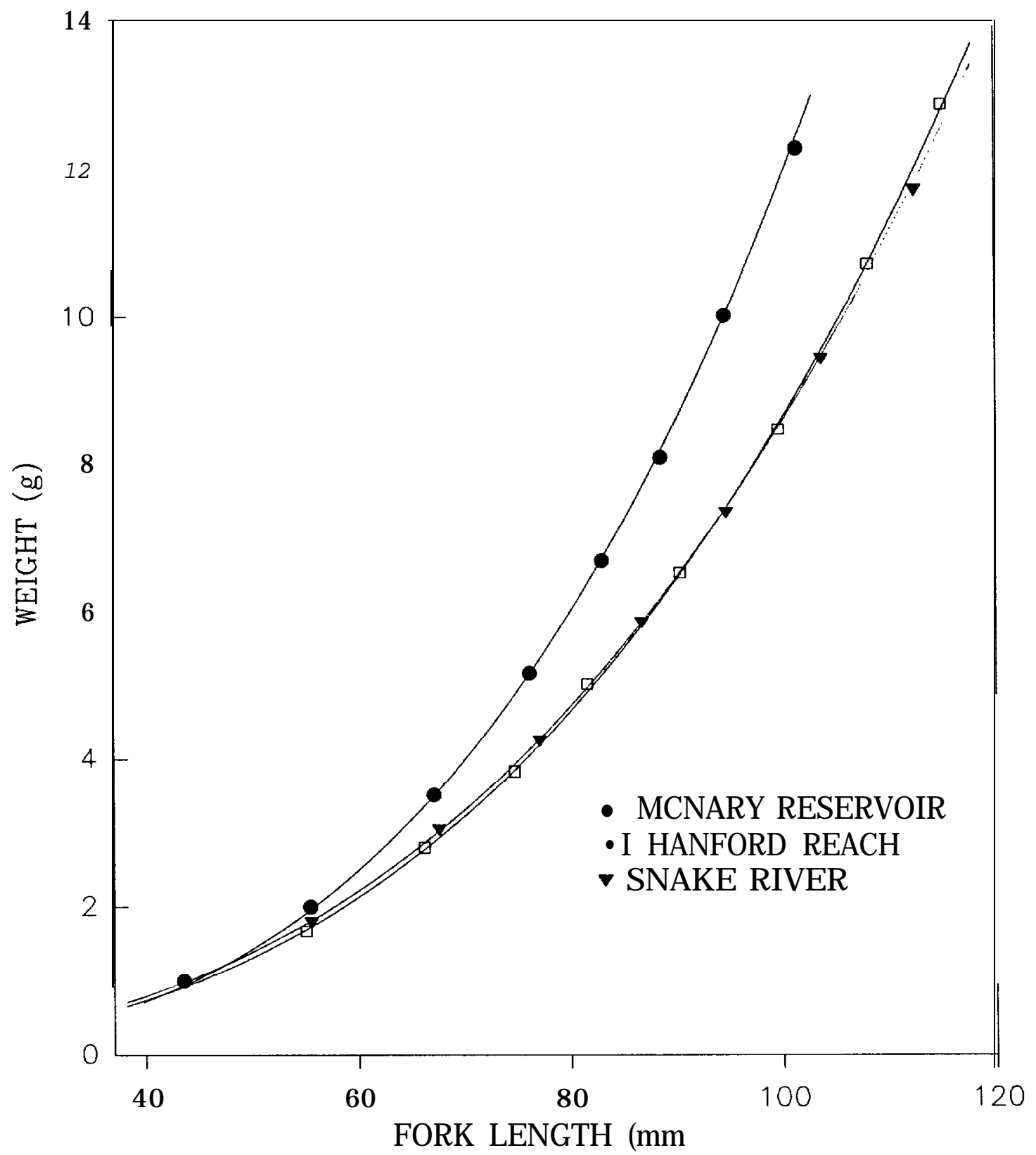

Figure 4.-Fitted curves for length and weight of all subyearling chinook salmon caught during 1992 in McNary Reservoir and the Hanford Reach in the Columbia River, Washington and in the Snake River, Idaho, Oregon, and Washington. 

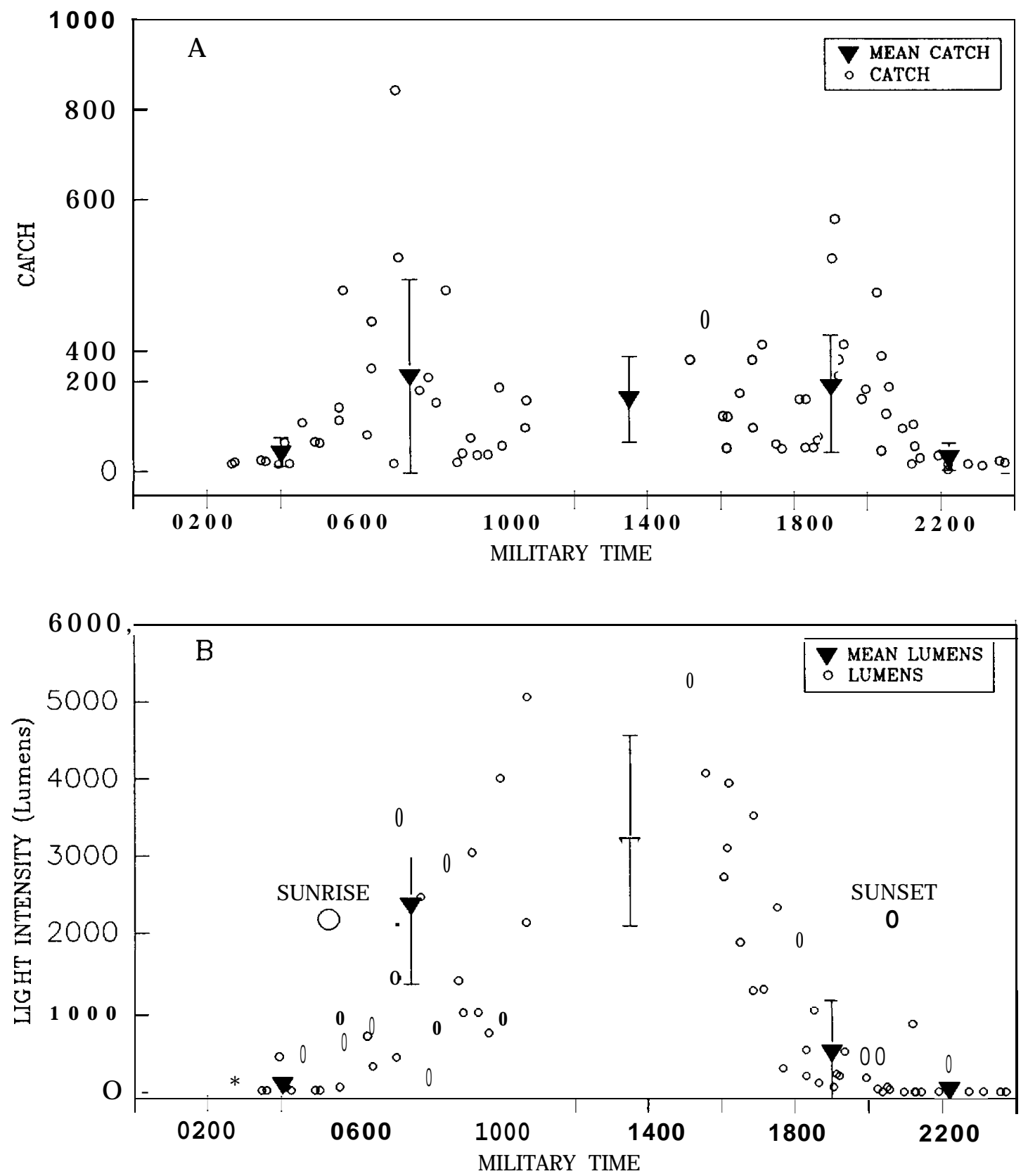

Figure 5.- (A) Catch of subyearling chinook salmon and (B) light intensities in McNary Reservoir. The catch and light intensities were grouped into five time catagories and means calculated. Means are displayed as triangles with corresponding standard deviations. 

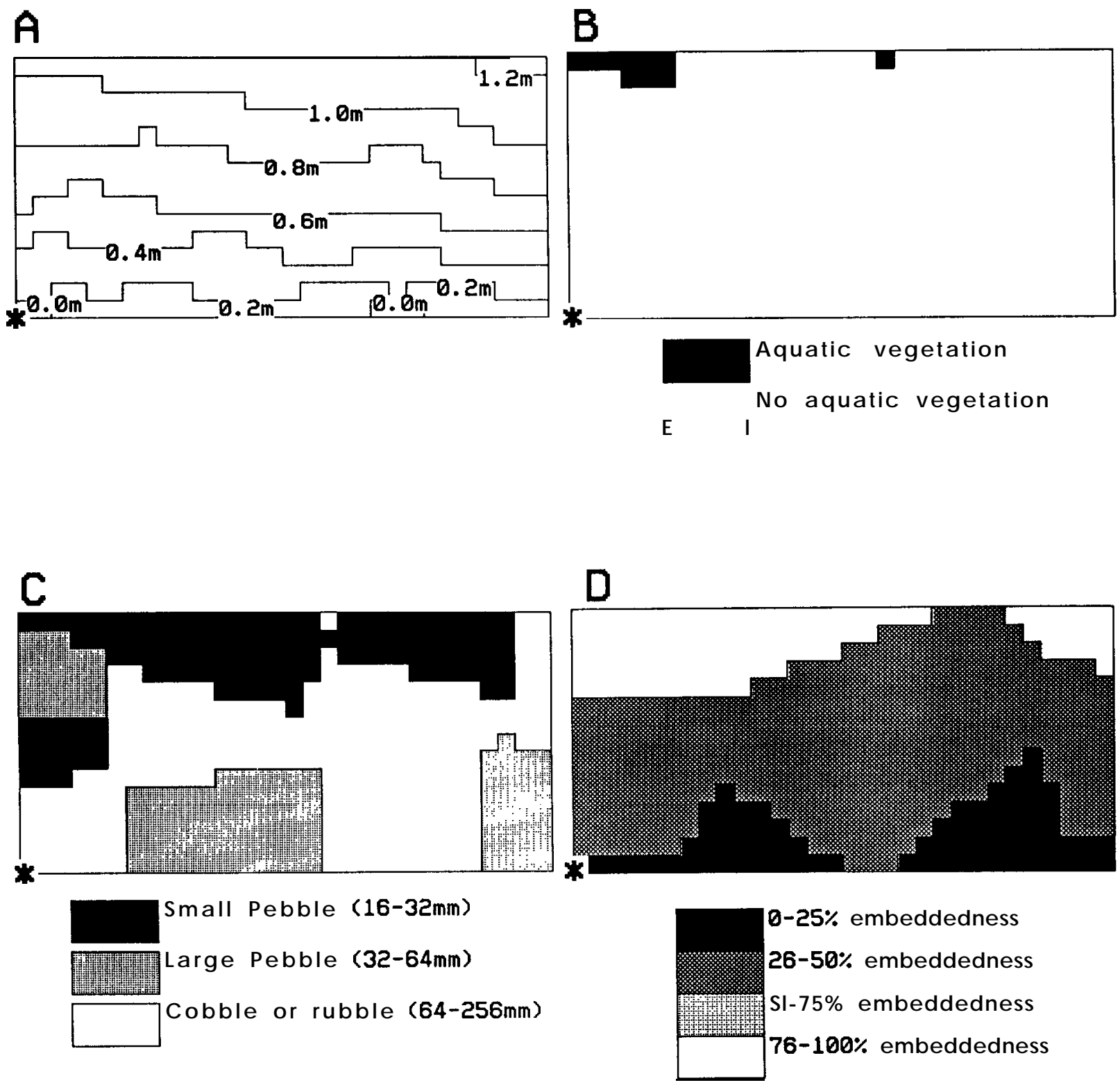

Figure 6.- Example of maps generated by GIS for determining areas of surveyed habitat variables (A) depth, (B) aquatic vegetation, (C) dominant substrate, and (D) embeddedness. Star (*) represents position of stake. 

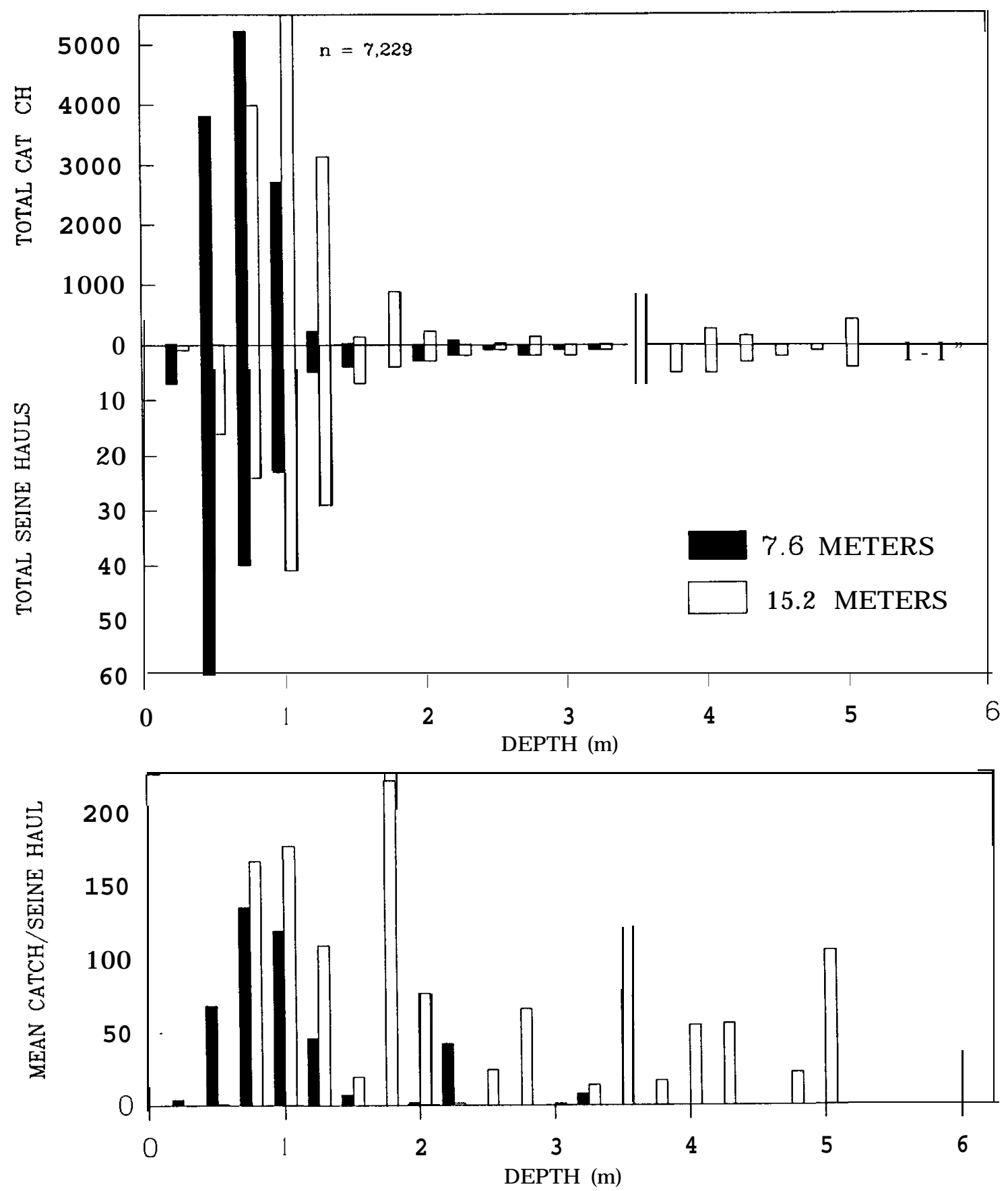

Figure 7.- Total catch, total seine hauls and mean catch/seine haul of subyearling chinook salmon. Depth was measured at $7.6 \mathrm{~m}$ and $15.2 \mathrm{~m}$ from the shoreline in McNary Reservoir of the Columbia River, Washington. 

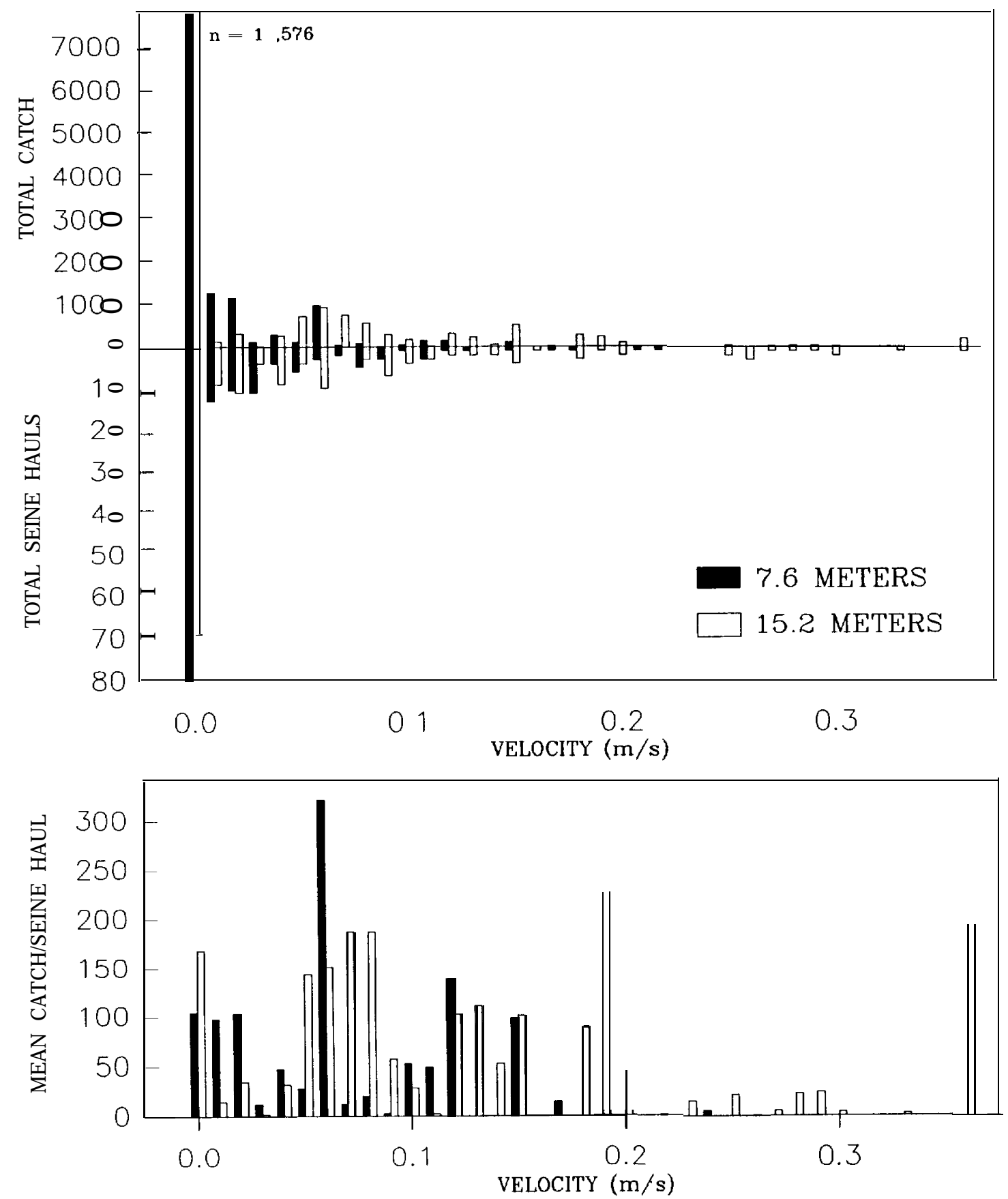

Figure 8.- Total catch, total seine hauls, and mean catch/seine haul of subyearling chinook salmon. Velocity was measured at 7.6 $\mathrm{m}$ and $15.2 \mathrm{~m}$ from the shoreline in McNary Reservoir of the Columbia River, Washington. 


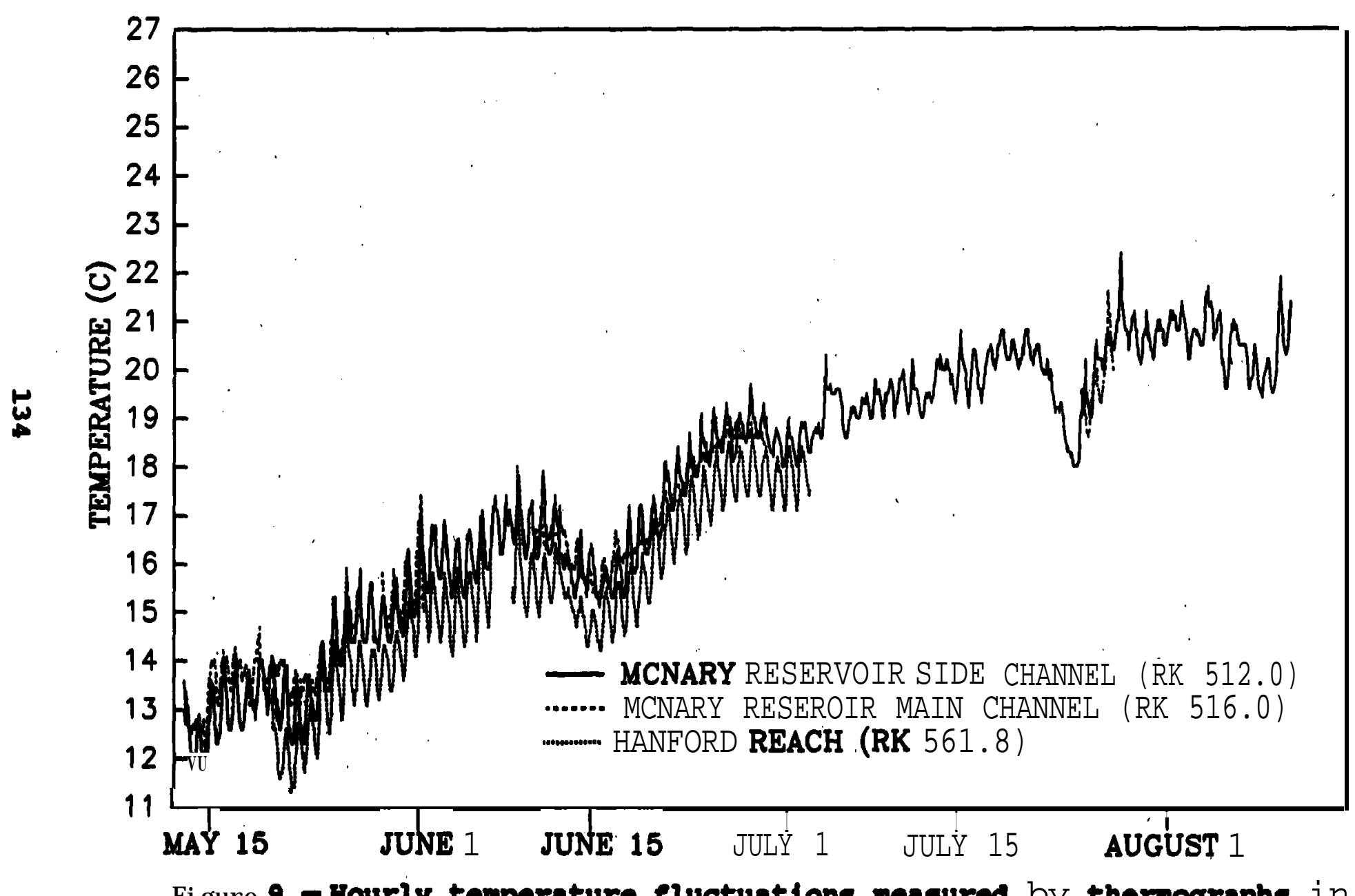

Fi gure 9.- Hourly temparature eluctuation maasured by thermograph in nearhore areas or MotaryRevervolr and the Hanford Reach, Columbia RIver, Wachington 1992. 

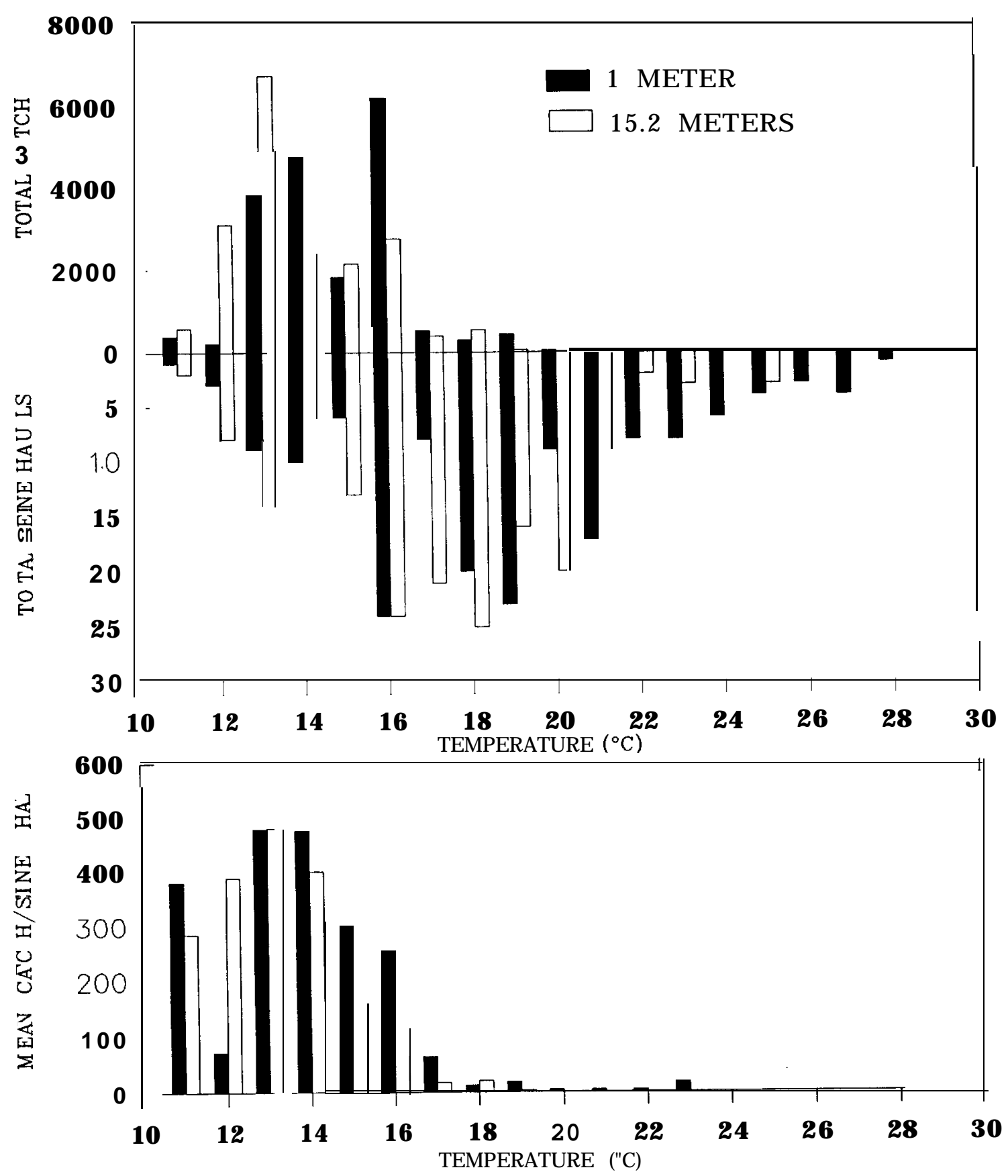

Figure 10.- Total catch, total seine hauls, and mean catch/seine haul of subyearling chinook salmon. Temperature was measured at $1 \mathrm{~m}$ and $15.2 \mathrm{~m}$ from the shoreline in McNary Reservoir of the Columbia River, Washington. 


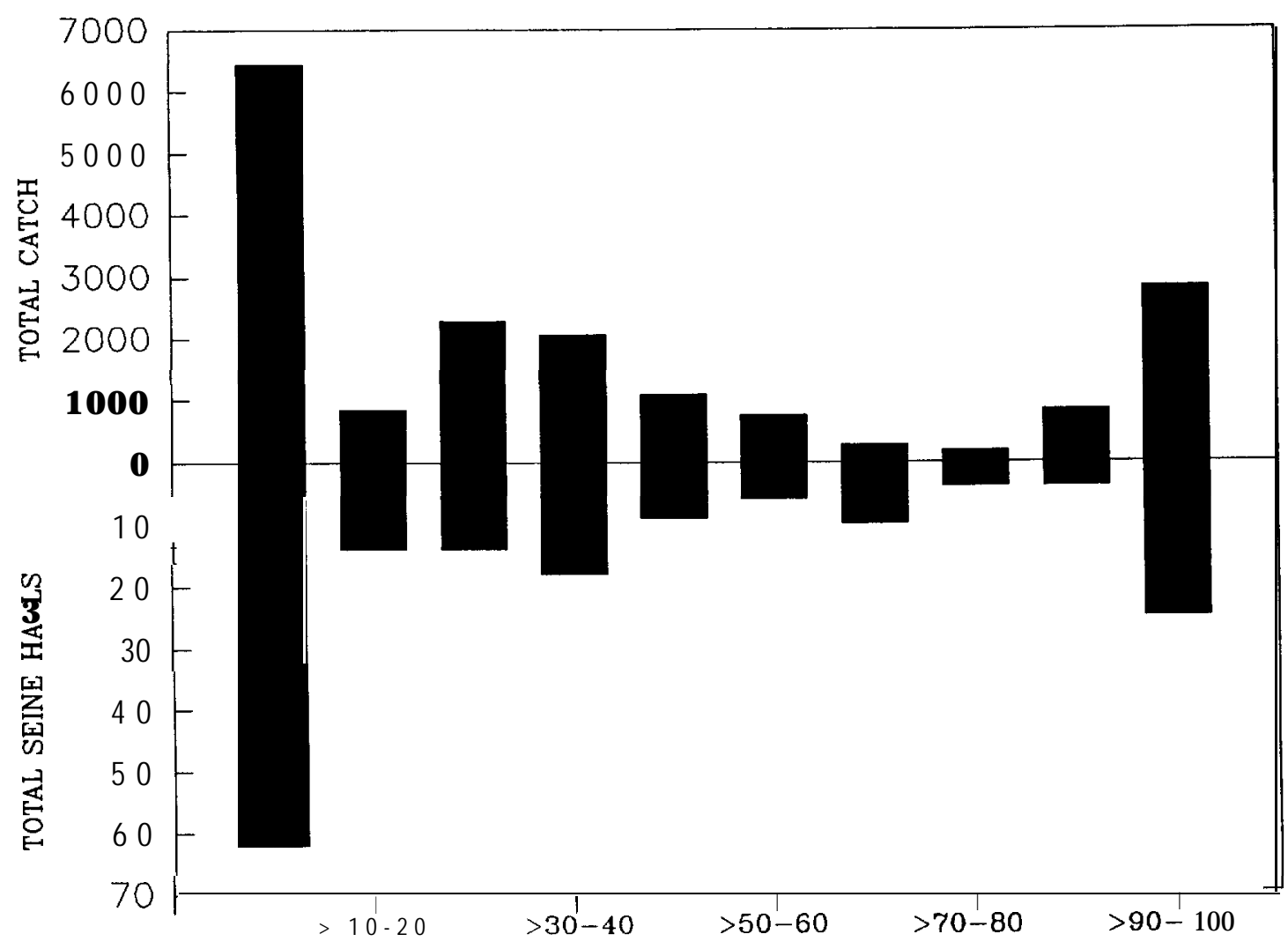

SUBSTRATE LESS THAN $2 \mathrm{~mm}$

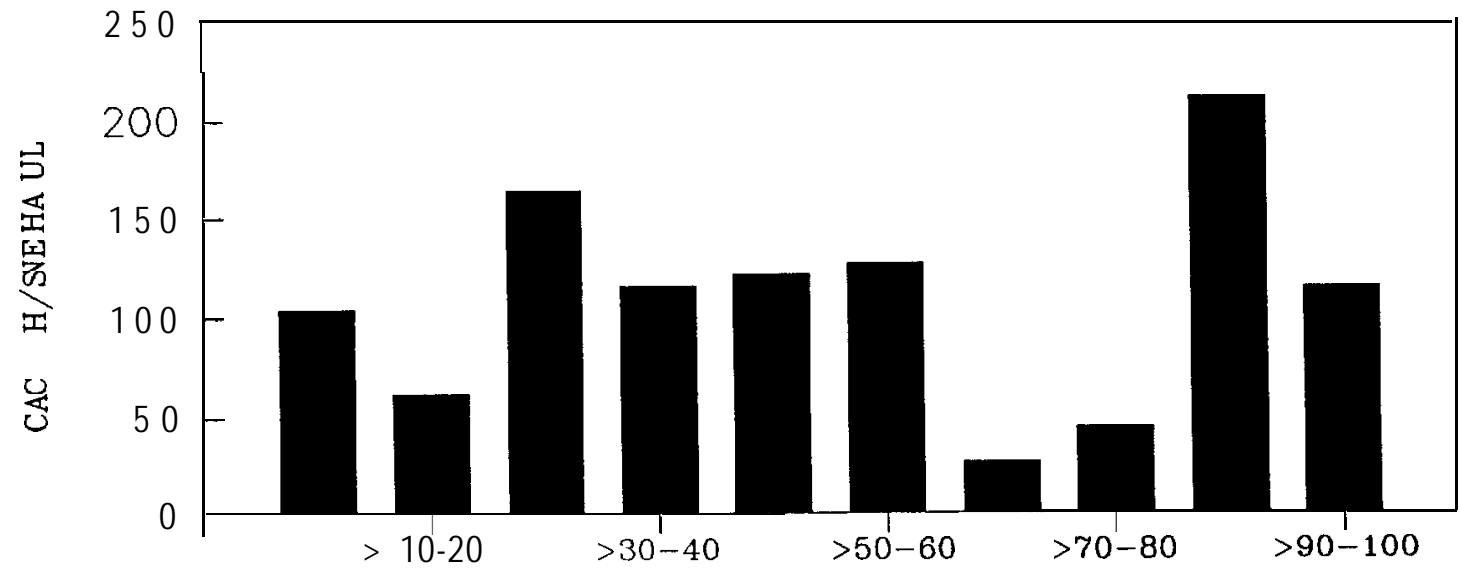

SUBSTRATE LESS THAN $2 \mathrm{~mm}$

Figure 11.- Total catch, total seine hauls, and mean catch/seine haul of subyearling chinook salmon in McNary Reservoir of the Columbia River, Washington. The percent area of the beach seine site was determined for each seine haul where dominant substrate was fines $<2 \mathrm{~mm}$ in size. Areas were combined into $10 \%$ intervals and graphed. 

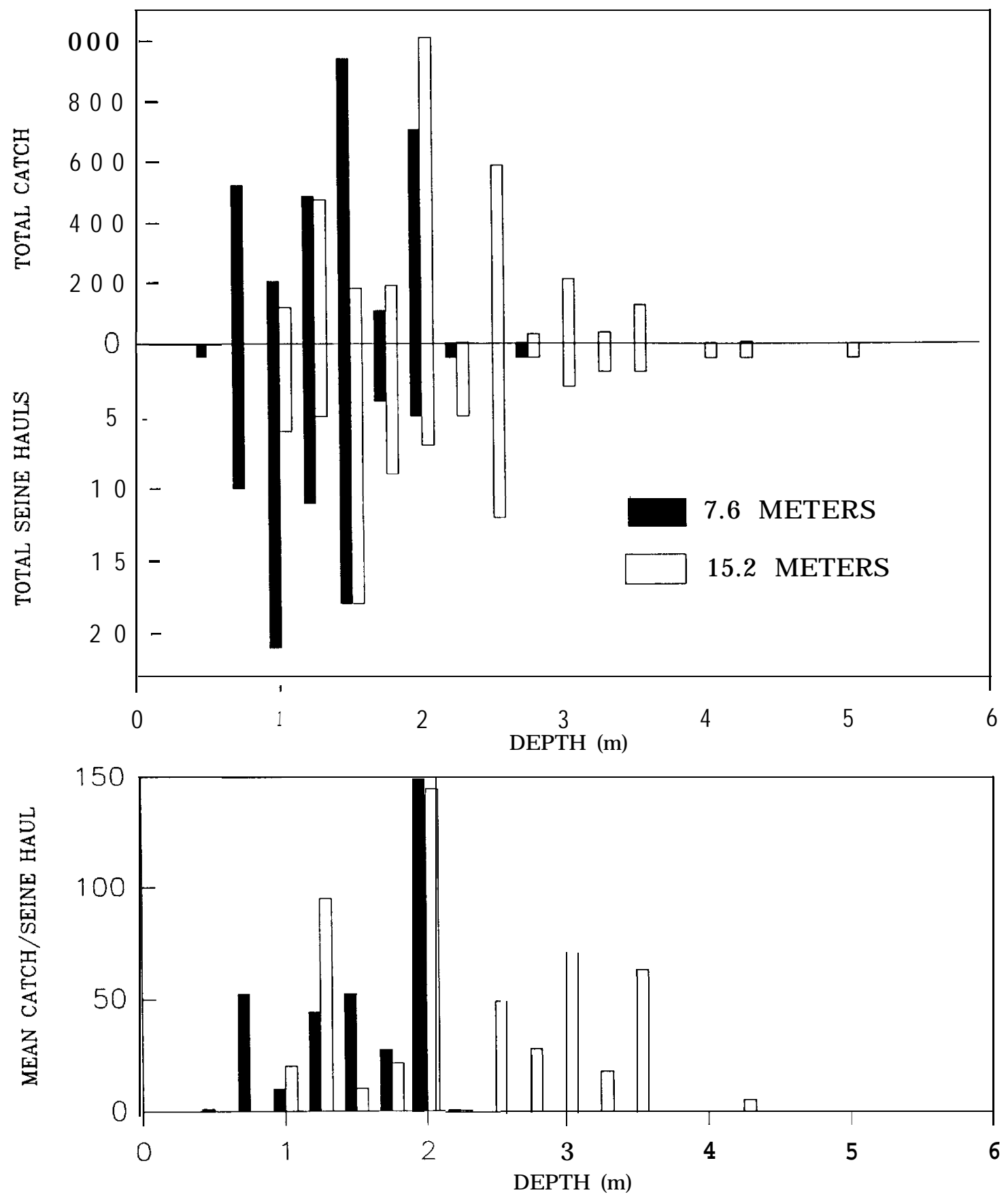

Figure 12.-Total catch, total seine hauls and mean catch/seine haul of subyearling chinook salmon. Depth was measured at $7.6 \mathrm{~m}$ and $15.2 \mathrm{~m}$ from the shoreline in the Hanford Reach of the Columbia River, Washington. 

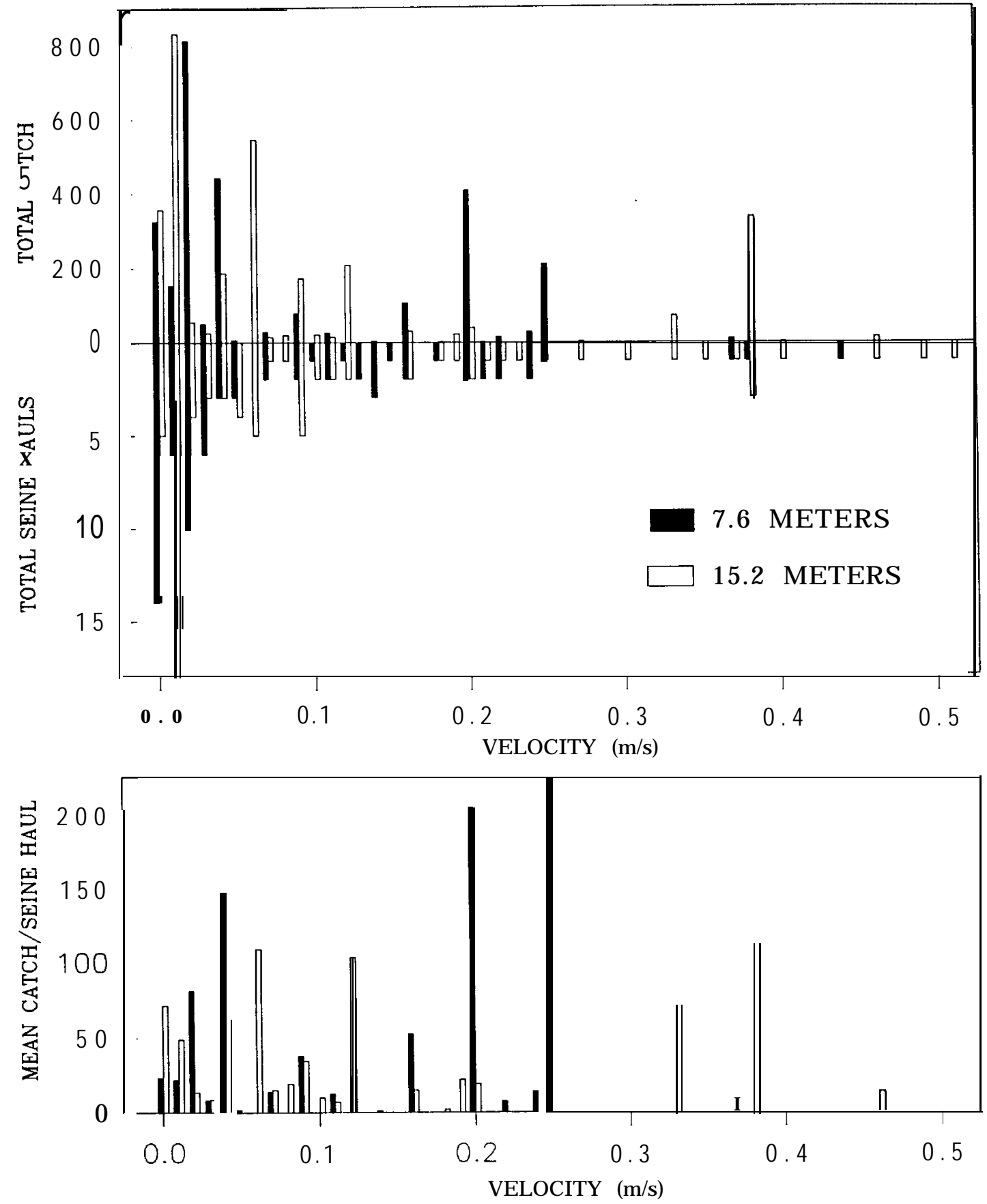

Figure 13.-Total catch, total seine hauls, and mean catch/seine haul of subyearling chinook salmon. Velocity was measured at $7.6 \mathrm{~m}$ and $15.2 \mathrm{~m}$ from the shoreline in the Hanford Reach of the Columbia River, Washington. 
thermograph in a nearshore area had a range of $1.5^{\circ} \mathrm{C}$ and were approximately a degree cooler than those from McNary Reservoir

(Figure 9). Effort was highest for sites where water temperature was between $14.0-18.9^{\circ} \mathrm{C}$ at both $1 \mathrm{~m}$ and $15.2 \mathrm{~m}$ from shore (Figure 14). Highest mean catch per seine haul occurred at temperatures between $14.0-15.9^{\circ} \mathrm{C}$ at $1 \mathrm{~m}$ and $13.0-13.9^{\circ} \mathrm{C}$ at $15.2 \mathrm{~m}$ from shore. Subyearling chinook salmon were not caught where temperature exceeded $21.2^{\circ} \mathrm{C}$ at $1 \mathrm{~m}$ from shore but were caught over the entire temperature range $\left(12-19.9^{\circ} \mathrm{C}\right)$ measured $15.2 \mathrm{~m}$ from shore. Most subyearling chinook salmon were caught in sites that contained a low percent of substrate $<2 \mathrm{~mm}$ (Figure 15).

In the Snake River, seining effort was highest between 0.76 $\mathrm{m}$ and $1.25 \mathrm{~m}$ depth at $7.6 \mathrm{~m}$ from shore and between $1.76-2.75 \mathrm{~m}$ at $15.2 \mathrm{~m}$ from shore, with no apparent trends in average catch per seine haul (Figure 16). Effort was highest for velocities $<0.05$ $\mathrm{m} / \mathrm{s}$ but the mean catch per seine haul was relatively high when velocities were between $0.3-0.4 \mathrm{~m} / \mathrm{s}$ (Figure 17). Effort was highest for sites where water temperature was between $13.0-17.9^{\circ} \mathrm{C}$ at $1 \mathrm{~m}$ and between $12.0-17.9^{\circ} \mathrm{C}$ at $15.2 \mathrm{~m}$ from shore (Figure 18). Highest mean catch per seine haul occurred at temperatures between $13.0-15.9^{\circ} \mathrm{C}$ at $1 \mathrm{~m}$ and $13.0-13.9^{\circ} \mathrm{C}$ at $15.2 \mathrm{~m}$ from the shore. No subyearlings were caught when temperatures exceeded $20.4^{\circ} \mathrm{C}$ at $1 \mathrm{~m}$ from shore or $19.2^{\circ} \mathrm{C}$ at $15.2 \mathrm{~m}$ from shore.

\section{Discussion}

The McNary Reservoir population of subyearling chinook salmon is primarily derived from fish naturally spawning in the Hanford Reach and releases from Priest Rapids State Fish Hatchery. Emergence of fry from redds in the Hanford Reach began 32 days earlier in 1992 than in 1991 (Carlson and Dell 1992).

Because of the earlier emergence, beach seining activities did not include the early rearing period of subyearlings in nearshore areas. Snake River collections were made during and following emergence until few subyearlings could be collected in the nearshore areas.

The mean fork length of subyearling chinook salmon remained lower in the Hanford Reach than in McNary Reservoir. The time required for subyearling chinook salmon to disperse $38 \mathrm{~km}$ from the downstream-most sampling point in the Hanford Reach to the upstream-most sampling point in McNary Reservoir may explain their consistently larger mean fork length in McNary Reservoir.

The greater mean fork length of subyearling chinook salmon in the snake River may be a result of warmer water temperature. Emergence of fry from redds in the Hanford Reach was reported to occur between 20 February and 21 April 1992 (Carlson and Dell 1992) and in the Snake River between 18 March and 25 May (Connor et al. this report). Since subyearlings emerged later but were larger in the Snake River than in the Hanford Reach, they 

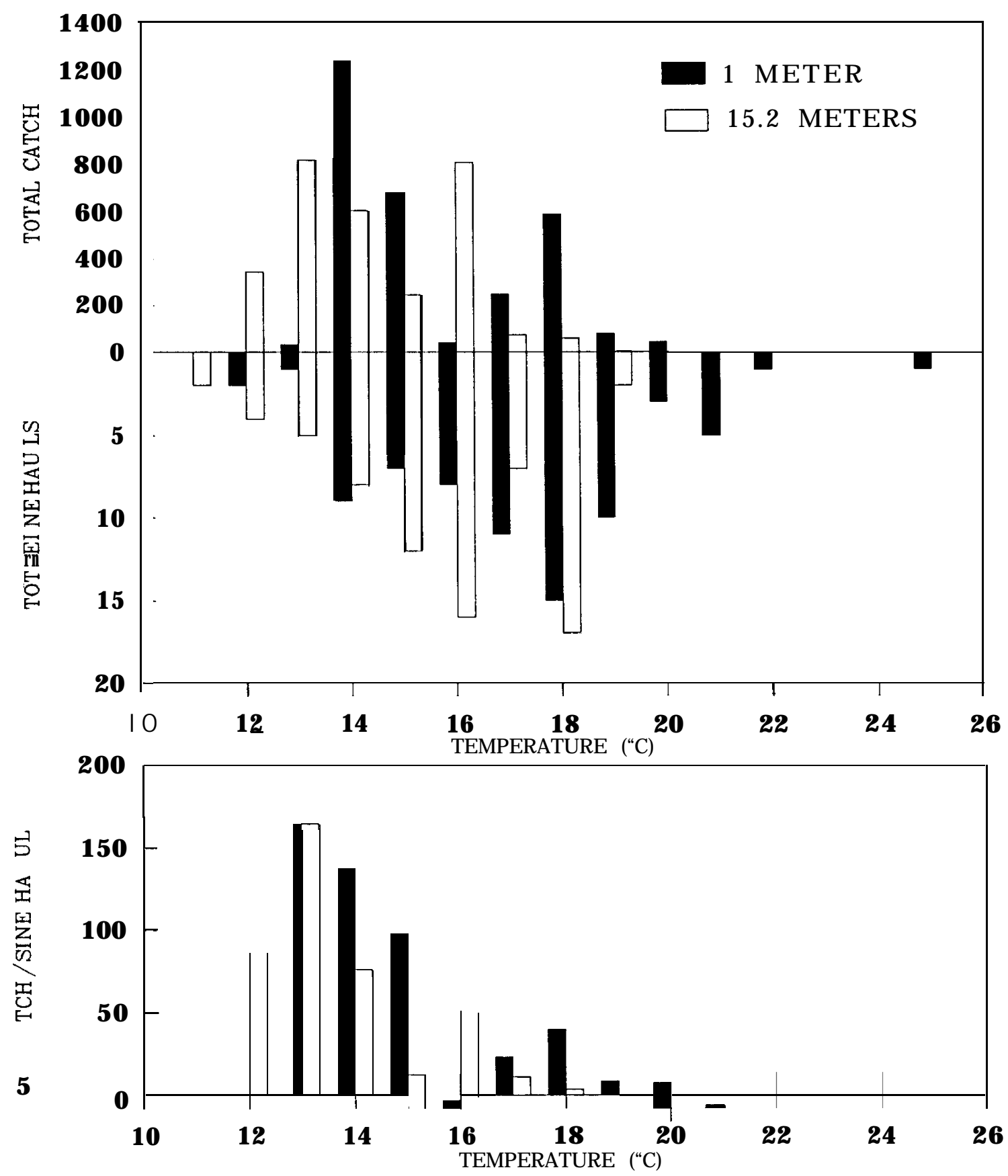

Figure 14.-Total catch, total seine hauls, and mean catch/seine haul of subyearling chinook salmon. Temperature was measured at $1 \mathrm{~m}$ and $15.2 \mathrm{~m}$ from the shoreline in the Hanford Reach of the Columbia River, Washington. 

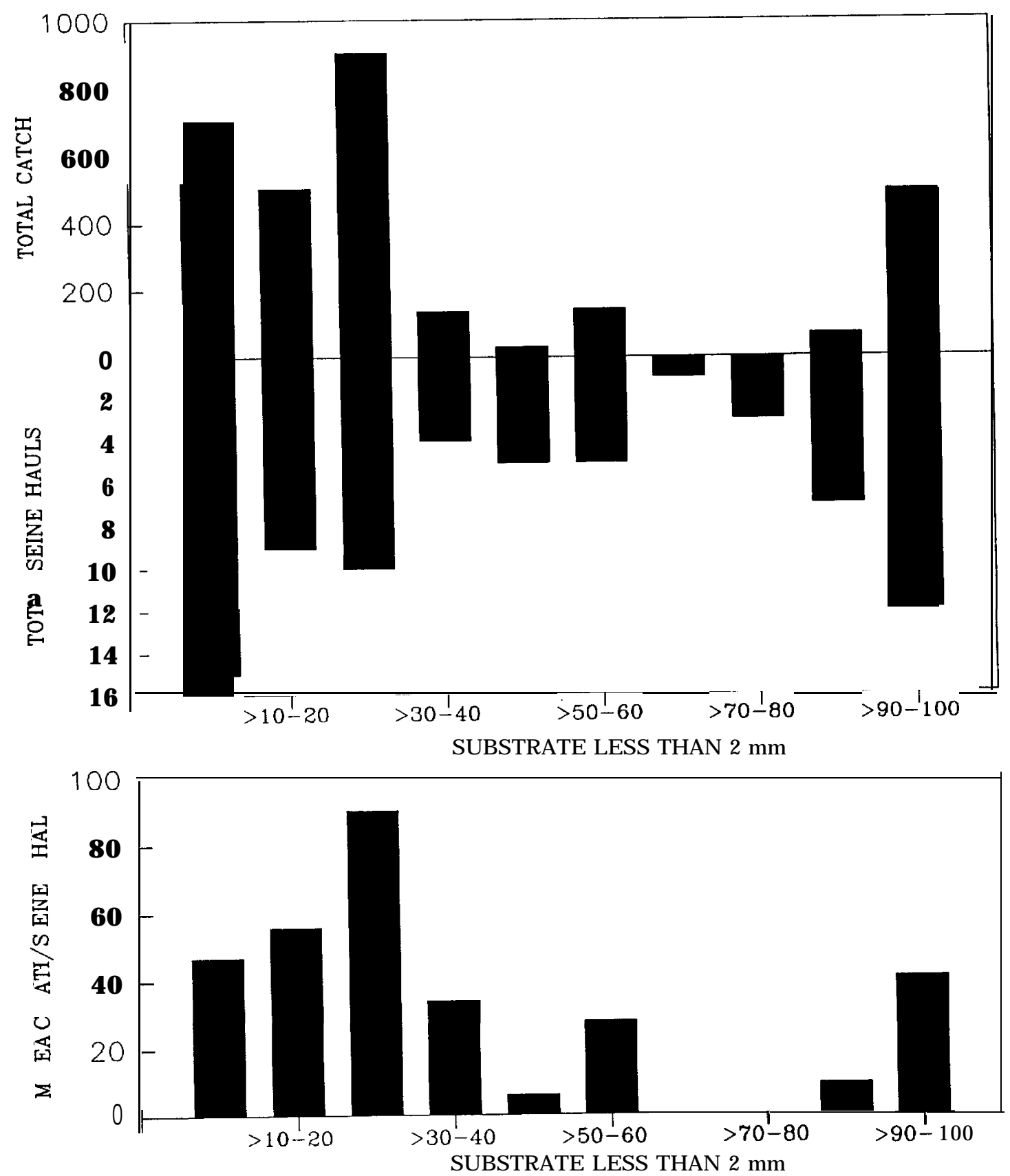

Figure 15.- Total catch, total seine hauls, and mean catch/seine haul of subyearling chinook salmon in the Hanford Reach of the Columbia River, Washington. The percent area of the beach seine site was determined for each seine haul where dominant substrate was fines $<2 \mathrm{~mm}$ in size. Areas were combined into $10 \%$ intervals and graphed. 

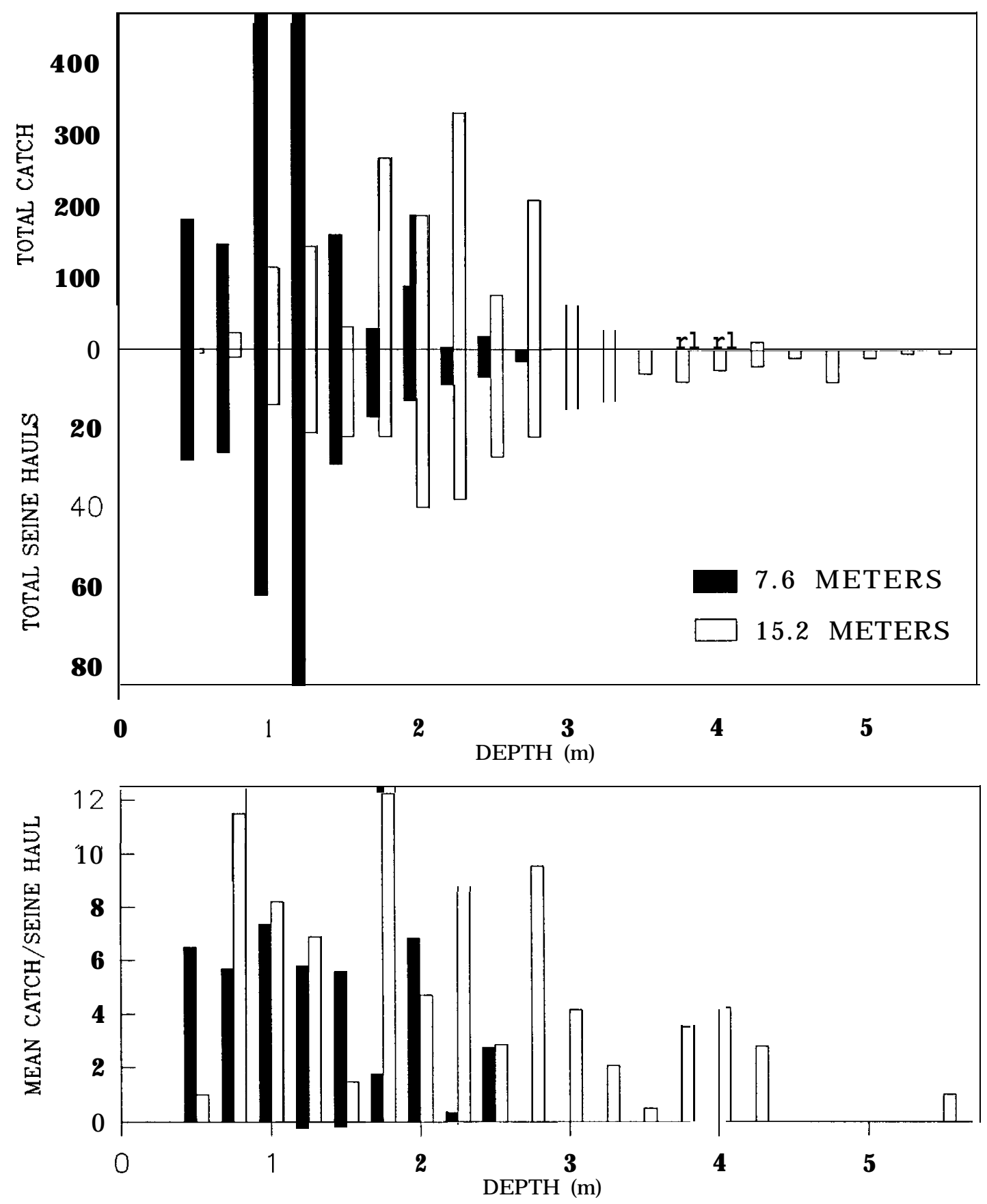

Figure 16.- Total catch, total seine hauls, and mean catch/seine haul of subyearling chinook salmon. Depth was measured at $7.6 \mathrm{~m}$ and $15.2 \mathrm{~m}$ from the shoreline in the Snake River, Idaho, Oregon, and Washington. 

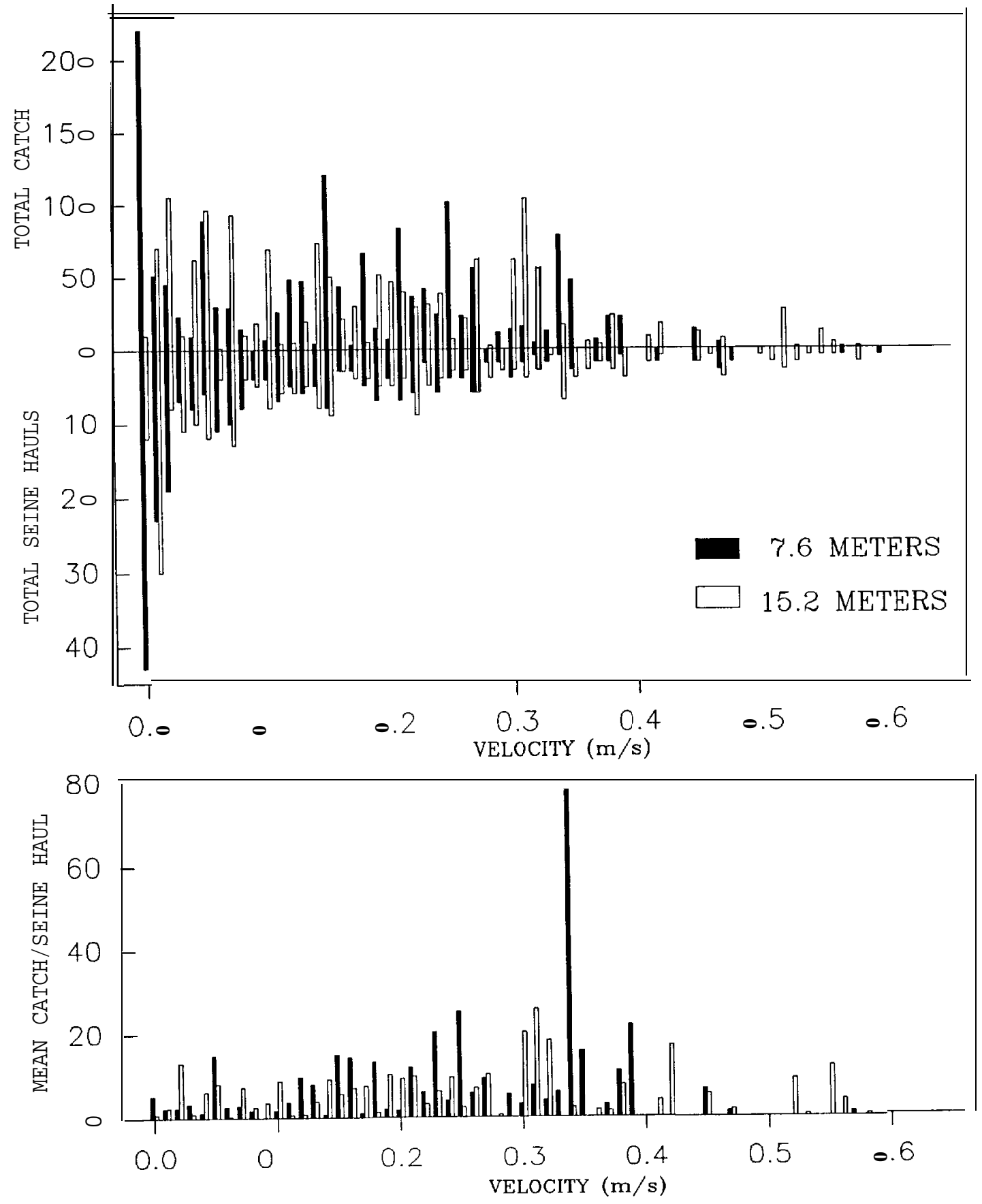

Figure 17.- Total catch, total seine hauls, and mean catch/seine haul of subyearling chinook salmon. Velocity was measured at $7.6 \mathrm{~m}$ and $15.2 \mathrm{~m}$ from the shoreline in the snake River, Idaho, oregon, and Washington. 

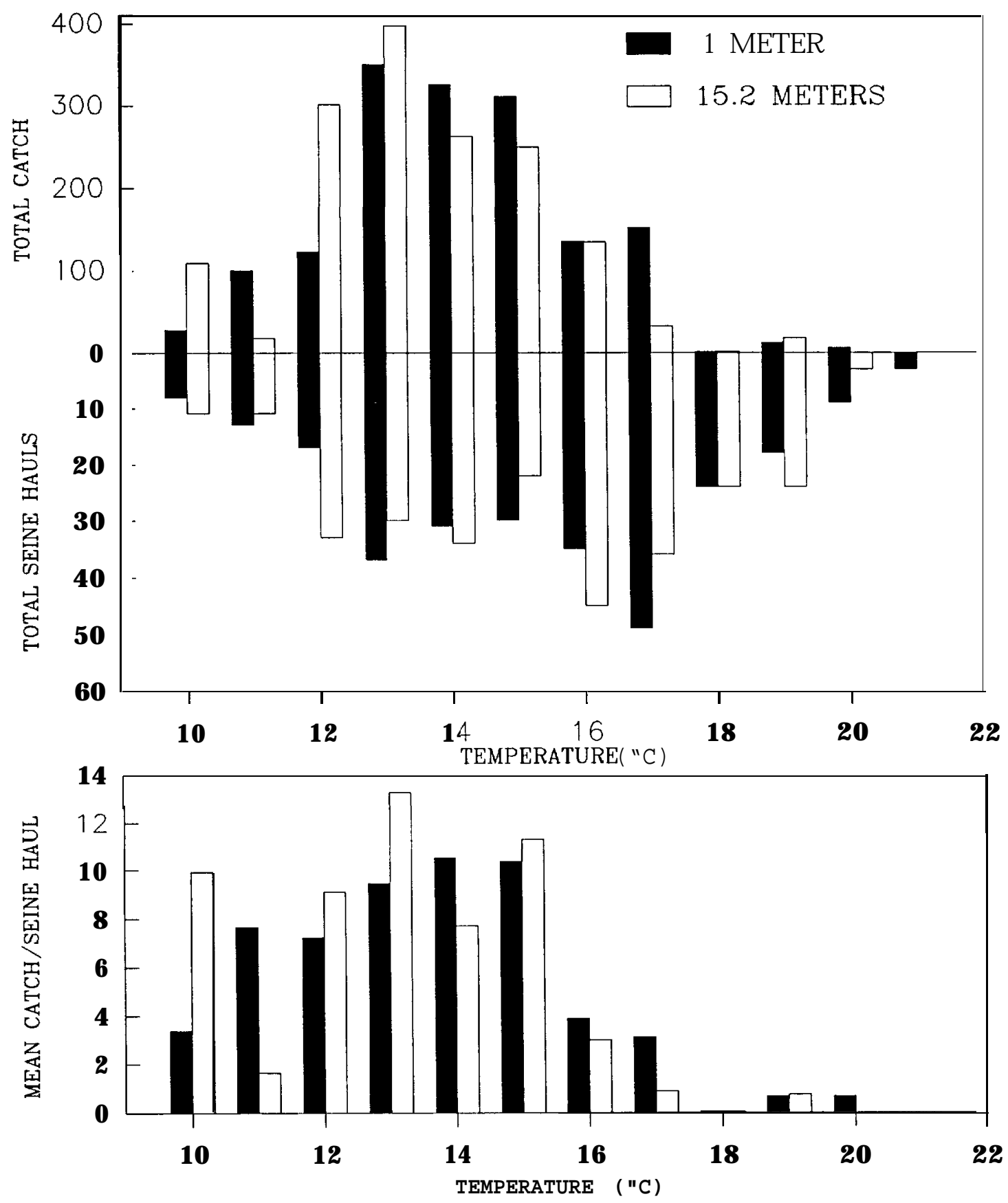

Figure 18.- Total catch, total seine hauls, and mean catch/seine haul of subyearling chinook salmon. Temperature was measured at $1 \mathrm{~m}$ and $15.2 \mathrm{~m}$ from the shoreline in the Snake River, Idaho, Oregon, and Washington. 
achieved considerably faster growth upon emergence. Fall chinook salmon fry emerged in the Hanford Reach when daily mean water temperatures were between $5^{\circ} \mathrm{C}$ and $9^{\circ} \mathrm{C}$ (Carlson and Dell 1992) but in the snake River they emerged when water temperatures were between $7.4^{\circ} \mathrm{C}$ and $14.9^{\circ} \mathrm{C}$ (Connor et al. this report). In a laboratory, as water temperature was increased feeding and growth of alevins began earlier (Heming et al. 1982). Subyearling chinook salmon in the Hanford Reach had the lowest feeding intensity in March and April when temperature ranged from $3^{\circ} \mathrm{C}$ to $8^{\circ} \mathrm{C}$ (Becker 1973). Subyearlings emerging in the water of the Hanford Reach may not grow as quickly as fish emerging in the relatively warmer snake River. In addition to temperature, stock differences could have contributed to observed differences in length. Longer emigration distance from the snake River than from the Hanford Reach may have selected for fish able to attain a larger size at emigration (Taylor 1990). Statistical analysis and collection of additional information should reveal whether subyearling chinook salmon attain larger size more quickly in the Snake River than in the Columbia River.

Although Snake River subyearling chinook salmon may increase in length more quickly, they appear to increase in weight in the same proportion to length as subyearlings in the Hanford Reach. The differences in the length-weight curve for fish in McNary Reservoir (Figure 4) could simply be a result of hatchery fish released into the Columbia River. Over seven million hatchery subyearlings were released below Priest Rapids Dam between 12 and 24 June 1992 (Fish Passage Center 1993). Following 12 June large numbers of subyearlings of larger size, greater weight, and less fusiform appearance were observed in the McNary Reservoir catch. The greater weight may have shifted the slope of the curve to the left for fish captured in McNary Reservoir compared to the riverine reaches.

The catch of subyearling chinook salmon was positively correlated with light and was significantly higher during the day than at night. The higher daytime catch in this study agrees with the findings of previous studies conducted with a beach seine in the Columbia River Estuary (Ledgerwood et al. 1991). Catch of subyearlings with a purse seine was also higher during the day than at night in the estuary (Ledgerwood et al. 1991) and in John Day Reservoir on the Columbia River (Sims et al. 1976). These studies suggested that chinook were moving deeper into the water column beyond the reach of the seines at night. Underwater observation studies have shown that preceeding darkness small diurnal schools of fish disbanded, moved to the bottom, and spaced themselves out on, or just above, the substrate (Emery 1973; Helfman 1981). This behavior was explained as a mechanism to avoid nocturnally active predators. Although it is generally accepted that net avoidance is greatest during the day, fish that become torpid at night may not be caught if the leadline skims over the top of them or if they are in water deeper than the 
reach of the net. If subyearlings are actively using nearshore areas during the day to move and feed, then daytime would be the most appropriate time to study movement patterns and active use of depth, velocity, substrate, and vegetation.

Shallow nearshore water depth may be important to subyearling chinook salmon by providing an environment with warmer water temperatures and lower risk of predation from large piscivorous fish. Bennett et al. (1993) found that subyearling chinook salmon in Lower Granite Reservoir were caught most frequently at low gradient sites. However, our findings suggest that there may be a minimum slope that subyearling chinook salmon will inhabit. Extremely shallow water may place small fish at a higher risk to avian predation by reducing escapement into deeper water depths; avian predation was observed daily by workers in the field during daylight hours. In addition, sites with very low slope dewater rapidly as reservoir and river levels fluctuate daily, and sometimes hourly, and may cause stranding.

As juvenile salmon grow they tend to shift to higher velocities and deeper water (Lister and Genoe 1970; Hillman et al. 1987). Personal observations in the field support these findings. Subyearlings were observed to feed at increasing distances from the shoreline as the season progressed and mean length increased. In late June, when beach seine hauls captured few subyearling chinook salmon, fish were observed feeding beyond the range of the beach seine. These observations suggest that the lack of a relationship between velocity and catch may be an artifact of grouping catches and velocity intervals across the entire sampling season and further study and analysis are required before a definitive conclusion can be reached.

Temperature avoidance may affect movement from nearshore areas. Mean catch dropped when temperatures exceeded $15.9^{\circ} \mathrm{C}$. In all three reaches the mean catch peaked when temperatures were between $12.0-15.9^{\circ} \mathrm{C}$. However, because river temperature and subyearling chinook salmon length both increase with time, it is difficult to separate temperature factors from the physical and physiological changes in subyearling chinook salmon that can affect behavior.

Substrate is commonly reported as an important component of the habitat for resident fish in streams and small rivers where it may provide protection from high velocity or predators. In the Snake River, Bennett et al. (1993) reported that of the total subyearling chinook salmon caught, 72\% were captured over substrates consisting of $>75 \%$ fines, however, effort was not reported. Catch of subyearling chinook salmon appeared to be proportional to effort over a range of percent fine substrate in the Hanford Reach and McNary Reservoir. High effort resulted in high total catch of subyearlings in McNary Reservoir and Hanford Reach. Since catch appeared dependent on effort, a conclusion 
regarding association of subyearling chinook salmon with substrate could not be supported, We propose that subyearling chinook salmon are generalistic feeders consuming prey items from the water column and the surface (Becker 1973; Rondorf et al. 1990) and moving freely in the water column as loose aggregates (personal observation). A snorkel study in the Sixes River, Oregon observed subyearling fall chinook salmon inhabiting backwater eddies near shore, distributed throughout the water column and consuming prey from the drift (Stein et al. 1972). This nondemersal behavior of subyearlings during the day could explain a lack of association between substrate and catch and the proportional relationship between effort and catch.

In conclusion, peak numbers of subyearling chinook salmon were captured during May in all reaches but as water temperatures increased above $15.9^{\circ} \mathrm{C}$, mean catch decreased. The Snake River subyearling chinook salmon emerged later and attained a larger size more quickly than the Columbia River subyearlings. Subyearlings were caught in significantly greater numbers during the day than during the night. Most subyearlings were caught in water between $0.5 \mathrm{~m}$ and $2.0 \mathrm{~m}$ deep. Substrate did not appear to have an influence on catch of subyearling chinook salmon in the main-stem Columbia River. Habitat shifts by fall chinook salmon may occur in the nearshore areas but that analysis has been deferred with only one year of data available. 


\section{References Cited}

Becker, C.D. 1973. Food and growth parameters of juvenile chinook salmon, Oncorhynchus tshawytscha, in central Columbia River. U.S. National Marine Fisheries Service Fishery Bulletin 71:387-400.

Bennett, D.H., J.A. Chandler, and L.K. Dunsmoor. 1990. Lower Granite Reservoir in-water disposal test: Results of the fishery, benthic and habitat monitoring program-Year 1 (1988). Completion report to U.S. Army Corp of Engineers, Walla Walla, Washington.

Bennett, D.H., J.A. Chandler, and G. Chandler. 1991. Lower Granite Reservoir in-water disposal test: Results of the fishery, benthic and habitat monitoring program-Year 2 (1989) . Completion Report to U.S. Army Corp of Engineers, Walla Walla, Washington.

Bennett, D.H., T.J. Dresser Jr., T.S. Curet, D.B. Lepla, and M.A. Madsen. 1993. Lower Granite Reservoir in-water disposal test: Results of the fishery, benthic and habitat monitoring program-Year 3 (1990). Completion Report to U.S. Army Corp of Engineers, Walla Walla, Washington.

Carlson, D. and M. Dell. 1992. Vernita Bar monitoring for 19911992. Annual Report. PUD of Grant County. Ephrata, Washington .

Dauble, D.D., R.H. Grey and T.L. Page. 1980. Importance of insects and zooplankton in the diet of O-age chinook salmon (Oncorhynchus tshawytscha) in the central Columbia River. Northwest Science 52:253-258.

Dauble, D.D., T.L. Page, and R.W. Hanf Jr. 1989. Spatial distribution of juvenile salmonids in the Hanford Reach, Columbia River. U.S. National Marine Fishery Service Fishery Bulletin 87:775-790.

Emery, A.R. 1973. Preliminary comparisons of day and night habits of freshwater fish in Ontario lakes. Journal of the Fisheries Research Board of Canada 30:761-774.

Fish Passage Center. 1993. Fish Passage Center 1992 Annual Report. Report to Bonneville Power Administration, Portland, Oregon.

Helfman, G.S. 1981. Twilight activities and temporal structure in a freshwater fish community. Canadian Journal of Fisheries and Aquatic Sciences 38:1405-1420. 
Heming, T.A., J.E. McInerney, and D.F. Alderdice. 1982. Effect of temperature on initial feeding in alevins of chinook salmon (Oncorhynchus tshawytscha). Canadian Journal of Fisheries and Aquatic Sciences 9:1554-1562.

Hillman, J.W., J.S. Griffith, and W.S. Platts. 1987. Summer and winter habitat selection by juvenile chinook salmon in a highly sedimented Idaho stream. Transactions of the American Fisheries Society 116:185-195.

Lister, D.B., and H.S. Genoe. 1970. Stream habitat utilization by cohabiting underyearlings of chinook (Oncorhynchus

tshawytscha) and coho (0. kisutch) salmon in the Big Wualicum River, British Columbia. Journal of the Fisheries Research Board of Canada 27:1225-1224.

Ledgerwood, R.D., F.P. Thrower, and E.M. Dawley. 1991. Diel sampling of migratory juvenile salmonids in the Columbia River Estuary. Fishery Bulletin 89:69-78.

Mains, E.M., and J.M. Smith. 1964. The distribution size, time, and current preferences of seaward migrant chinook salmon in the Columbia and Snake rivers. Washington State Department of Fisheries, Fisheries Research Papers. 2(3):5-43.

Orth, D.J. 1983. Aquatic habitat measurements. Pages 61-84 in L.A. Nielsen and D.L. Johnson, editors. Fisheries techniques. American Fisheries Society, Bethesda, Maryland.

Platts, W.S., W.F Megaham, and H.W. Minshall. 1983. Methods for evaluating stream, riparian. and biotic conditions. USDA Forest Service, General Technical Report. INT-138. Intermountain Forest and Range Experiment Station, Ogden, Utah.

Ricker, W.E. 1958. Handbook of computations for biological statistics of fish populations. Fisheries Research Board of Canada. Bulletin 119. Ottawa, Ontario, Canada.

Rondorf, D.W., G.A. Gray, and R.B. Fairley. 1990. Feeding ecology of subyearling chinook salmon in riverine and reservoir habitats of the Columbia River. Transactions of the American Fisheries Society 119:16-24.

SAS Institute. 1988. SAS/STAT User's Guide, Release 6.03 Edition. SAS Institute Inc., Cary, North Carolina.

Sims, C.W., R.C. Johnson, and W.W. Bentley. 1976. Effects of power peaking operations on juvenile salmon and steelhead trout migrations 1975. Progress Report (Contract DACW57-76- 
F-0303) to U.S. Army Corps of Engineers Portland, Oregon and National Marine Fisheries Service, Seattle, Washington.

Stein, R.A., P.E. Reimers, and J.D. Hall. 1972. Social interaction between juvenile coho (Oncorhynchus kisutch) and fall chinook slamon (O. tshawytscha) in Sixes River, Oregon. Journal of the Fisheries Research Board of Canada 29:1737-1748.

Taylor, E.B. 1990. Environmental correlates of life-history variation in juvenile chinook salmon, Oncorhynchus tshawytscha (Walbaum). Journal of Fish Biology 37:1-17.

Zimmerman M.A. and L.A. Rasmussen. 1981. Juvenile salmonid use of three Columbia River backwater areas proposed for subimpoundment. U.S. Department of the Interior. Fish and Wildlife Service. Ecological Services. Portland, Oregon. 
CHAPTER SEVEN

Distribution of Juvenile Chinook Salmon
and American Shad in McNary and John Day Reservoirs

by

J.A. McCann, E.E. Kofoot, C.R. Sprague,

J.A. Jackson, and D.H. Feil

National Biological Survey

Columbia River Research Laboratory

Cook, Washington 98605, USA 


\section{Introduction}

Considerable research has been conducted to determine the influence of flow on the rate of juvenile chinook salmon

Oncorhynchus tshawytscha outmigration in the Columbia River (Raymond 1969; Sims et al. 1981; Faurot et al. 1982; Miller and Sims 1983, 1984). Smolt travel time comparisons have been made between preand post-impoundment (Raymond 1969, 1988), and early and late migrants (Giorgi 1991), but there is still little agreement as to the importance of flow in regards to juvenile chinook salmon migration (Giorgi 1991; Berggren and Filardo 1993). Part of the difficulty stems from the inability to study any single environmental factor versus fish migration rate. Various authors have proposed smoltification, flow, time of year, water temperature, turbidity, and lunar phase as important in determining rate or readiness to migrate seaward. Furthermore, juvenile salmon movement and distribution within reservoir environments remains poorly understood.

Several investigators correlated fish movement in John Day Reservoir with flow using radio telemetry data (Sims et al. 1981; Faurot et al. 1982; Miller and Sims 1983, 1984). Incidental hydroacoustic data were gathered on juvenile salmonid distribution during a study of predator distributions in Lower Granite Reservoir (Thorne et al. 1992). Still there is a need to determine the distribution of juvenile salmon in the main stem reservoirs of the Columbia and Snake rivers to better understand how changes in water flow affect their migration.

The objective of this study was to determine if distribution of subyearling chinook salmon in main stem reservoirs explains the relatively slow downstream migration during summer. This study seeks to define the role of water velocity and other environmental variables in determining the distribution of subyearling chinook salmon in the cross sections of reservoirs. The first year of work reported here was used to develop an integrated sampling system and gather preliminary data to determine the best sampling protocols and analytical approaches.

\section{Methods}

Hydroacoustics and trawl surveys were conducted on McNary and John Day reservoirs during the summer of 1992. McNary Reservoir surveys were conducted from 7 July to 16 July and John Day Reservoir was sampled $22 \mathrm{July}$ to 7 October. These reservoirs were selected because of the large number of subyearling fall chinook salmon that are naturally produced in the Hanford Reach or released from hatcheries upriver. 
McNary Reservoir was divided into reaches for hydroacoustic surveys. Three reaches were selected for sampling, each $6 \mathrm{~km}$ long, based on potential diversity between hydrologic crosssections. Reach 1 (river kilometer (RK) 476 to RK 483), located $8 \mathrm{~km}$ above McNary Dam had the deepest water and lowest water velocities. Reach 2 (RK 497 to RK 502) was of intermediate depth and water velocity. Reach 3 (RK 512 to RK 518), $16 \mathrm{~km}$ below the confluence of the snake and Columbia rivers had the shallowest water and highest water velocities. In John Day Reservoir three reaches were also surveyed, but only data from reach 2, RK 385 to RK 391, are reported here.

Within each reach, four transects were randomly selected within each $1.5 \mathrm{~km}$ of river. Transects were set up perpendicular to the shore. This design allowed random selection of starting transects and was a compromise between total random sampling which would have been inefficient and systematic sampling which could introduce the greatest bias into the samples. Transects were sampled beginning at the most down-river transect and proceeded sequentially upstream so that fish detected in one transect would not likely be detected in the next transect, thereby reducing potential covariance among transects.

The hydroacoustic survey vessel was equipped with a dual beam echosounder for detecting fish in the water column, an acoustic doppler current profiler (ADCP) for measuring water column velocities, and a midwater trawl for capturing fish. During each transect the echosounder recorded echo intensity of fish in the water column, while the ADCP simultaneously recorded velocity profiles. By using a dual beam echosounder system the relative size of fish could be determined from the recorded information. A global positioning system (GPS), which fixes latitude and longitude, was used to locate and navigate transects. The latitude and longitude information was linked to the echosounder data so fish locations could be mapped.

A midwater trawl made of monofilament mesh was used to collect data on fish size and species composition in pelagic areas of the reservoir. These data were used to verify size estimates and target strengths from hydroacoustic surveys. Fish concentrations were identified during hydroacoustic surveys and trawl samples were collected in areas of highest concentration after all hydroacoustic transects within a river kilometer had been completed. The trawl was deployed for five minutes at a designated sampling depth. Fish were identified to species, measured, and released.

ADCP data were collected in an unprocessed form in 0.5 meter depth intervals. The ADCP uses $600 \mathrm{KHz}$ frequency pings to ensonify small particles in the water such as silt, plankton, and organic debris. An ensemble of pings is generated and the Doppler shift is measured from the echoes off particles within 
each depth interval. Particle velocities are estimated from the magnitude of shift in frequency of echoes, and north, east, and vertical velocity vectors are subsequently generated. The velocity vectors are then combined to generate a velocity magnitude for each depth interval within an ensemble. Each unprocessed ensemble takes four to five seconds to complete. After comparing the results of averaging raw data ensembles for $10 \mathrm{~s}, 20 \mathrm{~s}$, and $30 \mathrm{~s}$ periods, in $0.5 \mathrm{~m}$ and $1 \mathrm{~m}$ depth intervals, unprocessed data for individual ensembles were combined and averaged over $30 \mathrm{~s}$ (30 m to $40 \mathrm{~m}$ depending on vessel speed) in 1 $\mathrm{m}$ depth intervals to assist in data analysis.

Relative fish size was determined by the target strength of echoes processed by the dual beam echosounder. An echo received from a single source is referred to as a target. Target strength is the echo intensity of ensonified objects in the water column. A grouping of targets that matches user defined criteria is classified as a fish and will have an average target strength from which fish size can be estimated. Fish located by the echosounder were matched to velocities measured by the ADCP using elapsed time and depth. This is based on trawl catch data and recorded average target strengths from -58 decibels (db) to -46 $\mathrm{db}$ which is the range expected for fish less than $200 \mathrm{~mm}$. Records of gas bubbles were identified by clustered and vertically rising patterns and were deleted.

The volume of water sampled by the echosounder was calculated for each $0.5 \mathrm{~m}$ depth interval generated by the ADCP using the estimated width of the echosounder beam at mid-depth of the velocity cell. Fish density per $10,000 \mathrm{~m}^{3}$ of water was computed for each group of transects based on the total volume of water sampled (ensonified) and the number of fish ensonified $(N)$, taking into account the inverted cone shape of the echosounder beam (i.e., a greater volume was sampled at greater depth).

Data from hydroacoustic transects were grouped for analysis by time and location into eight groups. The frequency of velocities and depth which fish were located were compared to an expected random distribution using a Kolmogorov-Smirnov Goodness of Fit test (Zar 1984). The frequency of velocities and depths which fish were located were also compared to the frequency of those variables in reservoir cross sections sampled. The number of fish was adjusted for ensonified volume sampled by the echosounder. Because of the preliminary nature of this report, the density estimates do not include an estimate of variability. Median values of water velocity in cross sections, depth in cross sections, and velocity and depths where adjusted numbers of fish were located were calculated as measures of central tendency and tested using the median test (Zar 1984). 


\section{Species composition}

\section{Results}

Juvenile chinook salmon made up 99\% of the trawl catch in McNary Reservoir surveys (Table 1). Average fork length of juvenile chinook salmon captured in trawl samples was $110 \mathrm{~mm}$ (range $91 \mathrm{~mm}$ to $150 \mathrm{~mm}$ ). The number of juvenile chinook salmon caught in trawl samples had diminished by 16 July at which time McNary Dam juvenile chinook salmon passage indices were also rapidly declining (Figure 1 ). We assumed that most fish with target strengths from $-58 \mathrm{db}$ to $-46 \mathrm{db}$ detected in McNary Reservoir during July were subyearling chinook salmon based on the trawl catches, target strengths, and juvenile salmon fish passage information at McNary Dam.

Juvenile American shad Alosa sapidissima made up 99\% of the trawl catch in John Day Reservoir where sampling began on 22 July . Average fork length of American shad captured in trawl samples was $66 \mathrm{~mm}$ (range $35 \mathrm{~mm}$ to $116 \mathrm{~mm}$ ). Juvenile chinook salmon and other species made up less than 1\% of trawl catch in John Day Reservoir (Table 1).

\section{Juvenile chinook salmon distribution}

Fish density during night sampling in July was about twice that observed during the daytime sampling. Fish density during night samples ranged from 22-39 fish/IO,000 $\mathrm{m}^{3}$ water for transects that began at 2045-2305 hours (Table 2). Density observed during the day ranged from 7-16 fish/10,000 $\mathrm{m}^{3}$ water for transects that began at 1248-1955 hours.

Fish located by echosounder were distributed randomly across the range of water velocities available in one of four groups of transects. In three groups of transects starting between 1248 and 2310 hours, the frequency distribution of water velocities selected by fish was significantly different from random ( $P$ C 0.05; Table 3). In a fourth group of transects in which sampling started at 2224 and 2305 hours, the frequency of water velocities selected by fish was randomly distributed $(P>0.05$; Table 3$)$.

The frequency of water velocities selected by fish did not reflect the frequency of water velocities available in reservoir cross sections. The water velocities measured by the ADCP were considered representative of those available in the reservoir cross sections and are presented as one meter deep cells with an average velocity for that cell (Figure 2). The availability

(number of cells) in the reservoir cross section with a specific water velocity is indicated by the open bars of the histograms in Figure 3 (Availability). The estimated density of fish at specific water velocities is shown by the black bars on the lower half of each plate (Usage; Figure 3). The frequency of water 
Table 1.- Species composition and catch for trawl surveys conducted in McNary and John Day reservoirs, 1992.

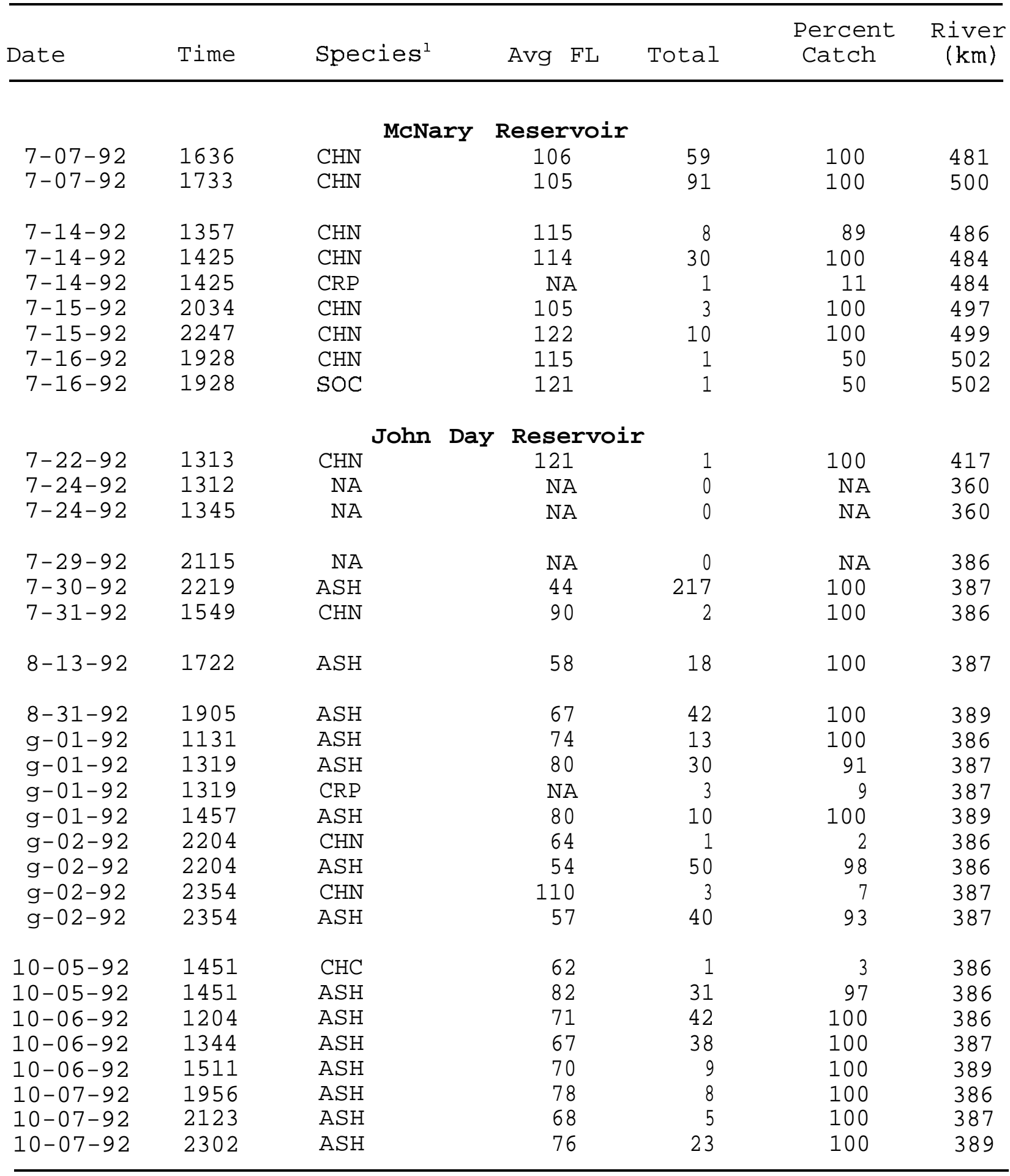

'Species abbreviations are ASH; American shad Alosa supidissima, CHC; channel catfish Ictulurus punctatus, CHN; chinook salmon O. tshawytscha, CRP; common carp Cyprinus carpio, and SOC; sockeye salmon O. nerka. 

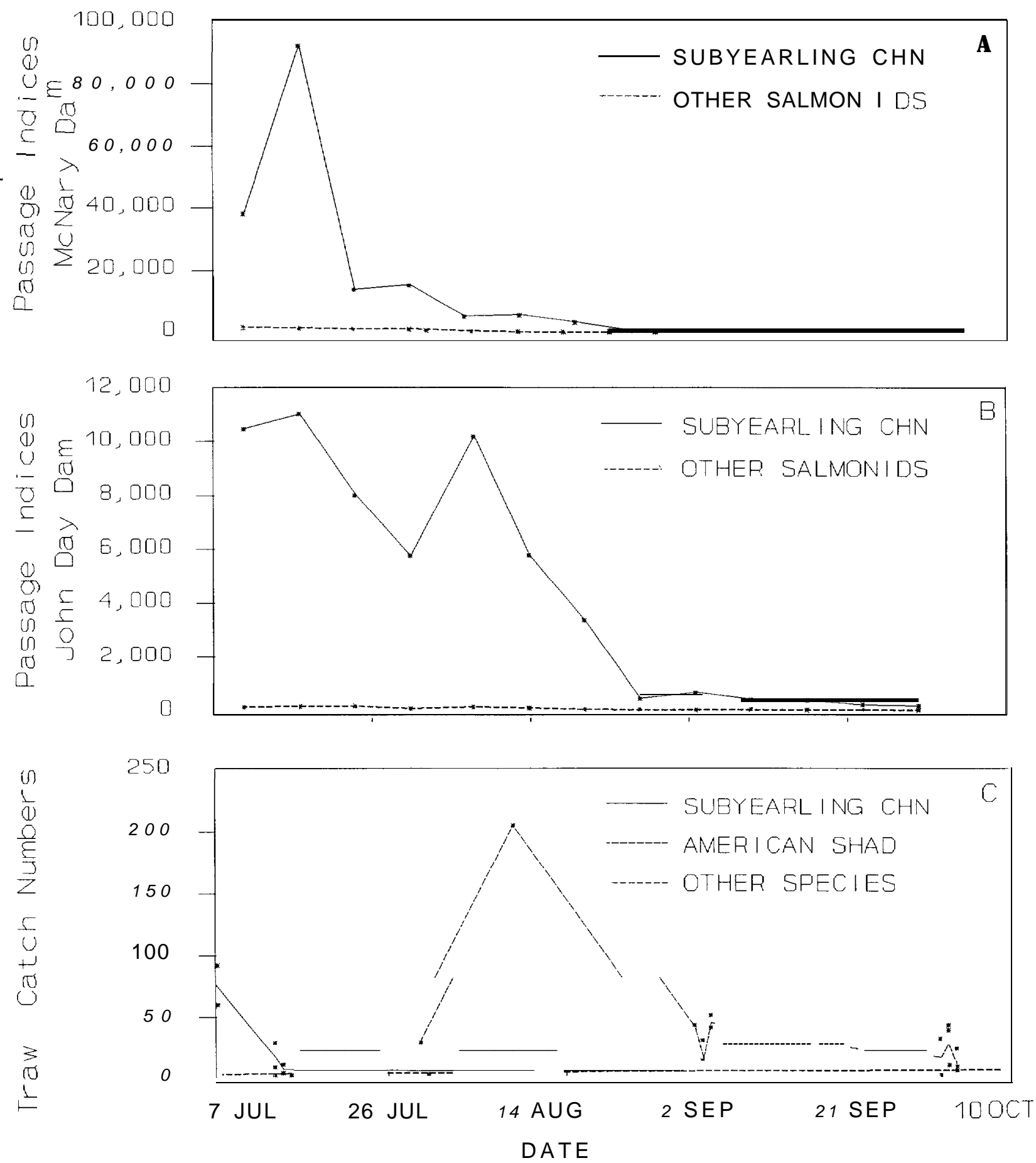

Figure 1.(A)-Daily passage indices of juvenile salmonids at McNary Dam (averaged and plotted weekly), from 7 July through 10 October 1992. (B) Daily passage indices of juvenile salmonids at John Day Dam (averaged and plotted weekly), from 7 July through 10 October 1992. (C) Trawl catch data from McNary and John Day reservoirs from 7 July through 10 October 1992. Each symbol represents a single trawl catch for that species or group. 
Table 2.-Representative hydroacoustic results for transects surveyed in MCNary Reservoir $7 \mathrm{July}$ to $16 \mathrm{July}$ and in John Day Reservoir 22 July to 7 October 1992 .

\begin{tabular}{|c|c|c|c|c|c|}
\hline Group & $\begin{array}{c}\text { River } \\
\text { Kilometer }\end{array}$ & Date & Time & $\begin{array}{l}\text { Number } \\
\text { of Fish }\end{array}$ & $\begin{array}{c}\text { Fish } \\
\text { Density }\end{array}$ \\
\hline 1 & $\begin{array}{l}512 \\
513\end{array}$ & $\begin{array}{l}7-11-92 \\
7-11-92\end{array}$ & $\begin{array}{l}1248 \\
1314\end{array}$ & $\begin{array}{l}7 \\
8\end{array}$ & $\begin{array}{l}11 \\
15\end{array}$ \\
\hline 2 & $\begin{array}{l}500 \\
500 \\
500\end{array}$ & $\begin{array}{l}7-8-92 \\
7-8-92 \\
7-8-92\end{array}$ & $\begin{array}{l}1900 \\
1932 \\
1955\end{array}$ & $\begin{array}{r}14 \\
8 \\
17\end{array}$ & $\begin{array}{r}13 \\
7 \\
16\end{array}$ \\
\hline 3 & $\begin{array}{l}512 \\
518 \\
518\end{array}$ & $\begin{array}{l}7-12-92 \\
7-12-92 \\
7-12-92\end{array}$ & $\begin{array}{l}2045 \\
2247 \\
2310\end{array}$ & $\begin{array}{r}16 \\
13 \\
6\end{array}$ & $\begin{array}{l}22 \\
30 \\
22\end{array}$ \\
\hline 4 & $\begin{array}{l}497 \\
499\end{array}$ & $\begin{array}{l}7-9-92 \\
7-9-92\end{array}$ & $\begin{array}{l}2224 \\
2305\end{array}$ & $\begin{array}{l}43 \\
47\end{array}$ & $\begin{array}{l}32 \\
39\end{array}$ \\
\hline 5 & $\begin{array}{l}387 \\
387 \\
387\end{array}$ & $\begin{array}{l}9-1-92 \\
9-1-92 \\
9-1-92\end{array}$ & $\begin{array}{l}1200 \\
1227 \\
1245\end{array}$ & $\begin{array}{r}31 \\
8 \\
19\end{array}$ & $\begin{array}{r}12 \\
3 \\
8\end{array}$ \\
\hline 6 & $\begin{array}{l}389 \\
389 \\
389\end{array}$ & $\begin{array}{l}8-31-92 \\
8-31-92 \\
8-31-92\end{array}$ & $\begin{array}{l}1752 \\
1815 \\
1836\end{array}$ & $\begin{array}{l}30 \\
40 \\
23\end{array}$ & $\begin{array}{l}13 \\
18 \\
11\end{array}$ \\
\hline 7 & $\begin{array}{l}386 \\
386 \\
386\end{array}$ & $\begin{array}{l}9-2-92 \\
9-2-92 \\
9-2-92\end{array}$ & $\begin{array}{l}2042 \\
2103 \\
2127\end{array}$ & $\begin{array}{l}61 \\
94 \\
86\end{array}$ & $\begin{array}{l}22 \\
32 \\
29\end{array}$ \\
\hline 8 & $\begin{array}{l}389 \\
389\end{array}$ & $\begin{array}{l}9-3-92 \\
9-3-92\end{array}$ & $\begin{array}{l}0020 \\
0107\end{array}$ & $\begin{array}{l}176 \\
278\end{array}$ & $\begin{array}{r}71 \\
121\end{array}$ \\
\hline
\end{tabular}

'Fish density reported as fish/10,000 $\mathrm{m}^{3}$. 
Table 3.-Results from Kolmogorov-Smirnov test of goodness of fit for subyearling chinook salmon and American shad based on availability and usage associated with velocity and depth in hydroacoustic transects in McNary and John Day reservoirs. Symbols: $*=P<0.05 ; * \star=P<0.01 ;$ NS $=$ no significant difference.

\begin{tabular}{|c|c|c|c|c|c|c|c|}
\hline \multirow[b]{2}{*}{ Group } & \multirow[b]{2}{*}{ Date } & \multirow[b]{2}{*}{$\begin{array}{l}\text { Start } \\
\text { time }\end{array}$} & \multirow[b]{2}{*}{$\mathrm{N}$} & \multicolumn{2}{|c|}{ Velocity } & \multicolumn{2}{|c|}{ Depth } \\
\hline & & & & $\begin{array}{l}\text { Range } \\
\text { Sampled }\end{array}$ & $\begin{array}{l}\text { Cells } \\
\text { Available }\end{array}$ & $\begin{array}{l}\text { Range } \\
\text { Sampled }\end{array}$ & $\begin{array}{l}\text { Cells } \\
\text { Available }\end{array}$ \\
\hline & & & & \multicolumn{2}{|c|}{ Subyearling } & Chinook & salmon \\
\hline 1 & $7-11-92$ & 1248 & 15 & $\star \star$ & $\star \star$ & NS & NS \\
\hline 2 & $7-08-92$ & 1900 & 39 & $\star$ & ** & $\star \star$ & $\star \star$ \\
\hline 3 & $7-12-92$ & 2045 & 35 & ** & ** & NS & NS \\
\hline \multirow[t]{2}{*}{4} & $7-09-92$ & 2224 & 90 & NS & ** & $\star *$ & $\star \star$ \\
\hline & & & & \multicolumn{4}{|c|}{ American shad } \\
\hline 5 & $9-01-92$ & 1200 & 58 & $\star \star$ & ** & NS & ** \\
\hline 6 & $8-31-92$ & 1752 & 93 & NS & ** & NS & ** \\
\hline 7 & $9-02-92$ & 2042 & 241 & $\star \star$ & $\star \star$ & $\star$ & $\star *$ \\
\hline 8 & $g-03-92$ & 0020 & 454 & $\star \star$ & ** & ** & ** \\
\hline
\end{tabular}




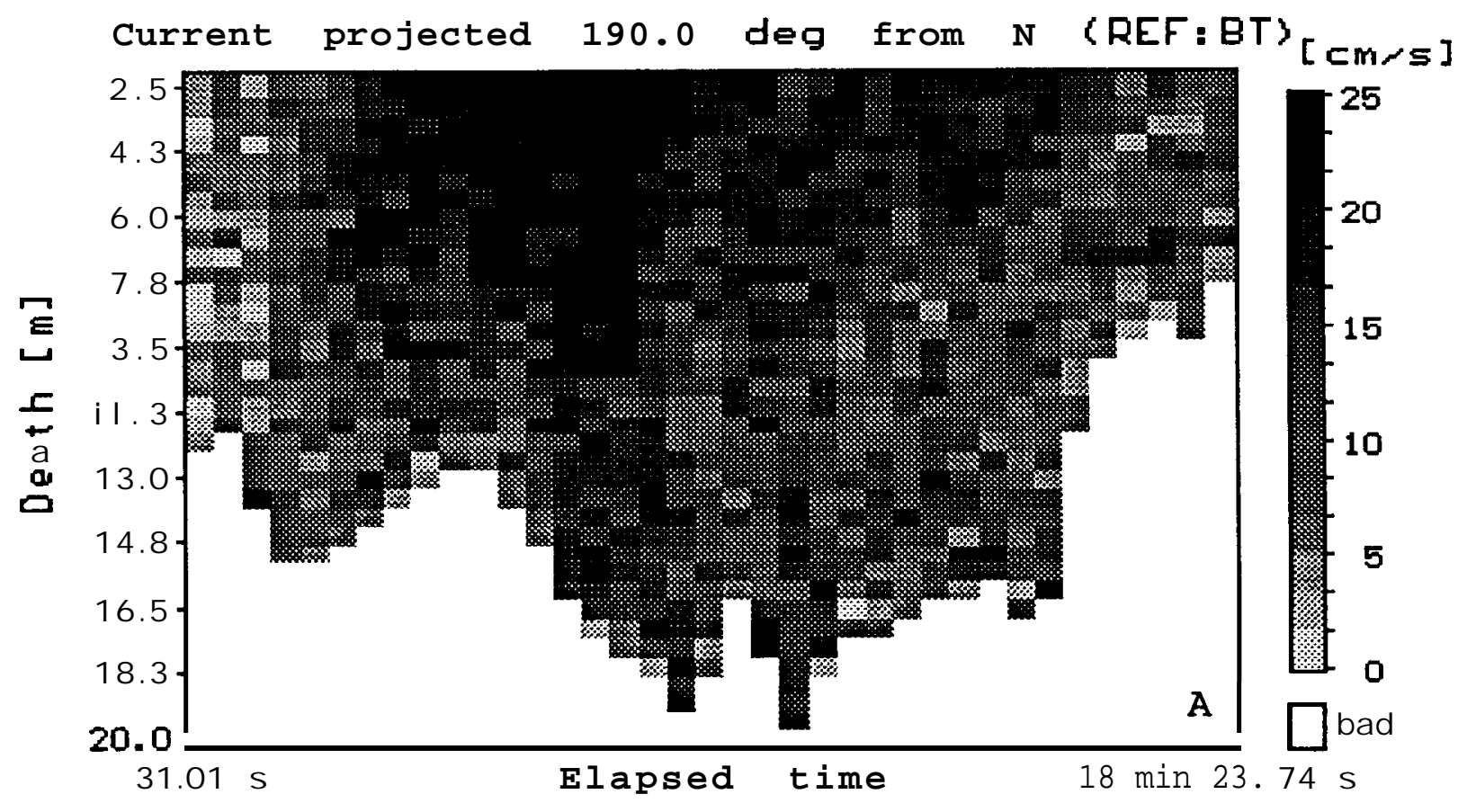

Figure 2.-Example of ADCP velocity profile for a reservoir cross section surveyed at river $\mathrm{km} \mathrm{500,} 8 \mathrm{July}$ 1992. Data were averaged every $30 \mathrm{~s}$ in $1 \mathrm{~m}$ depth intervals. 


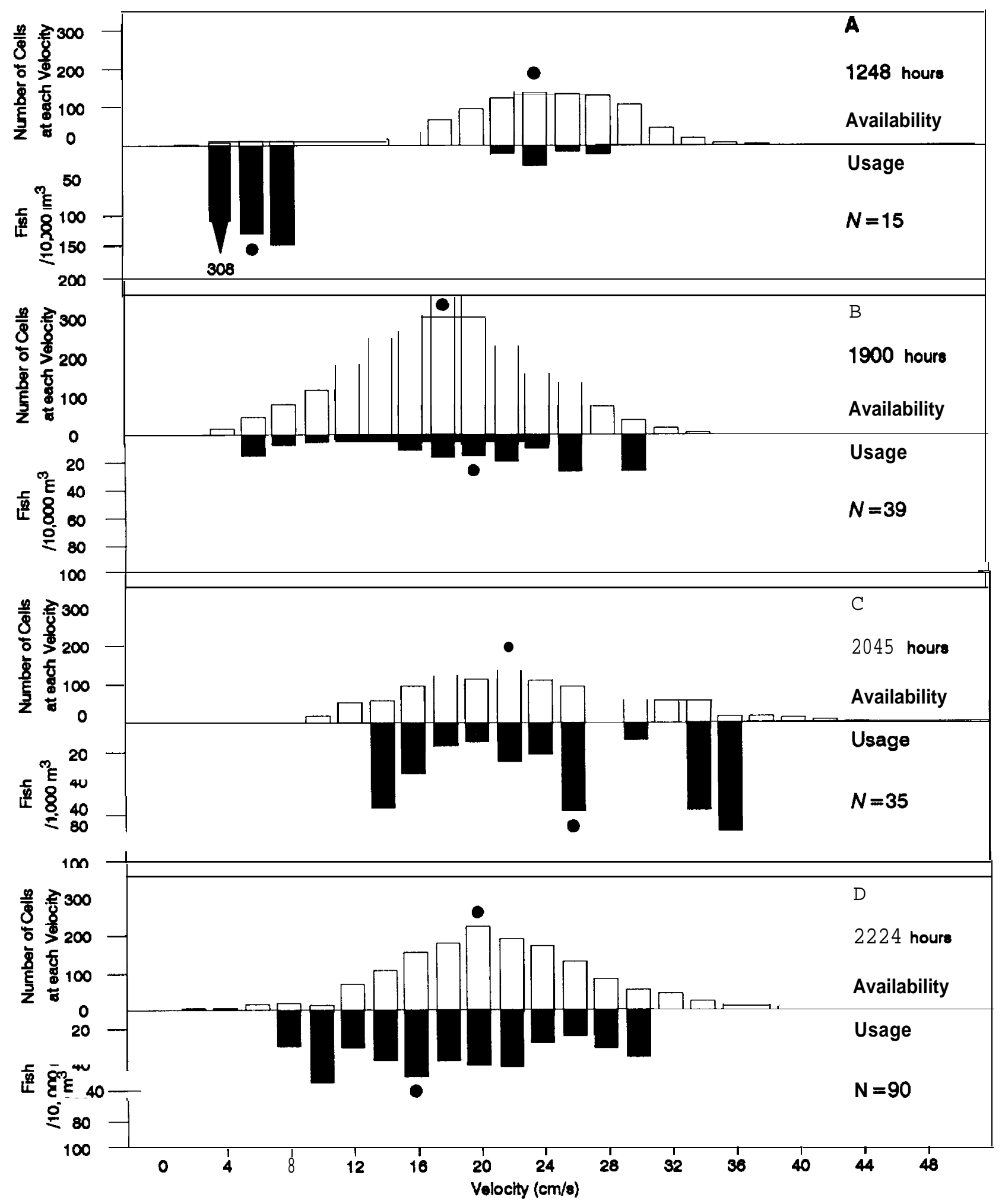

Figure 3.- Frequency histograms of available velocity cells and associated fish density by velocity for hydroacoustic surveys performed in McNary Reservoir, 1992. Medians are denoted as (•). 
velocities available and the water velocities selected by fish were significantly different ( $P$ C 0.01 ; Table 3$)$. Fish detected in transects starting at 1248 and 1314 hours were mostly distributed in waters with velocities $<8 \mathrm{~cm} / \mathrm{s}$ (Figure $3 \mathrm{~A}$ ), whereas fish detected during night transects starting at 20452305 hours were associated with velocities ranging from $8 \mathrm{~cm} / \mathrm{s}$ to $36 \mathrm{~cm} / \mathrm{s}$ (Figure 3B, C, D).

The depth selected by fish during day and night may have been associated with the morphology of the cross sections. The depths fish selected in transects sampled starting at $\times 248-1314$ hours and 2045-2310 hours were not significantly different from random and were not related to availability $(P>0.05$; Table 3$)$.

These transects were located in reach 3 between RK 512-518 which was the shallowest cross section with the highest velocities. Fish in transects located in reach 2 between RK 497-500 selected depths that were significantly different from random and from water velocities available in the cross section $(P<0.01$; Table 3). Median depths of fish in the deeper reach shifted from $5.5 \mathrm{~m}$ at 1900-1955 hours to 11.6 $\mathrm{m}$ at 2224-2305 hours (Table 4; Figure $4 \mathrm{~B}, \mathrm{D})$.

\section{Juvenile American shad distribution}

Fish density during night sampling in John Day Reservoir was considerably higher than that observed during daytime sampling. Fish density during night samples ranged from 22-121 fish/10,000 $\mathrm{m}^{3}$ of water for transects that began at 2042-0107 hours (Table 2). Density observed during the day ranged from 3-18 fish/10,000 $\mathrm{m}^{3}$ water for transects that began at 1200-1836 hours.

Fish located by echosounder were distributed randomly across the range of water velocities available in one of four groups of transects. In three groups of transects starting at 1200, 2042, and 0020 hours, the water velocities selected by fish were significantly different from a random distribution $(P<0.05$; Table 3). In a fourth group of transects sampled beginning at 1752 hours, the frequency of water velocities selected by fish was not distributed significantly different from random $(P>$ 0.05 ; Table 3).

The frequency of water velocities selected by fish did not reflect the frequency of water velocities available in reservoir cross sections. The water velocities available and the water velocities selected by fish were significantly different in all groups of transects sampled in John Day Reservoir $(P<0.01$; Table 3). Density of fish in transects started between 2042 and 0107 hours, during darkness, tended to be higher in water velocities $2-12 \mathrm{~cm} / \mathrm{s}$ compared to the $12-24 \mathrm{~cm} / \mathrm{s}$ velocity range 
Table 4.-Distribution medians of subyearling chinook salmon and American shad associated with velocity and depth in hydroacoustic transects in MCNary and John Day reservoirs.

\begin{tabular}{|c|c|c|c|c|c|c|}
\hline \multirow[b]{2}{*}{ Group } & \multirow[b]{2}{*}{ Date } & \multirow[b]{2}{*}{$\begin{array}{l}\text { Start } \\
\text { time }\end{array}$} & \multicolumn{2}{|c|}{ Velocity $(\mathrm{cm} / \mathrm{s})$} & \multicolumn{2}{|c|}{ Depth (m) } \\
\hline & & & $\begin{array}{l}\text { Fish } \\
\text { median }\end{array}$ & $\begin{array}{l}\text { Velocity } \\
\text { median }\end{array}$ & $\begin{array}{l}\text { Fish } \\
\text { median }\end{array}$ & $\begin{array}{l}\text { Depth } \\
\text { median }\end{array}$ \\
\hline & & & \multicolumn{2}{|c|}{ Subyearling } & Chinook & salmon \\
\hline 1 & $7-11-92$ & 1248 & 4.4 & 23.2 & 6.2 & 6.0 \\
\hline 2 & $7-08-92$ & 1900 & 19.9 & 17.1 & 5.5 & 7.4 \\
\hline 3 & $7-12-92$ & 2045 & 25.3 & 21.9 & 5.9 & 6.6 \\
\hline \multirow[t]{2}{*}{4} & $7-09-92$ & 2224 & 15.1 & 19.7 & 11.6 & 8.2 \\
\hline & & & \multicolumn{4}{|c|}{ American shad } \\
\hline 5 & $g-01-92$ & 1200 & 27.5 & 11.5 & 15.5 & 10.9 \\
\hline 6 & $8-31-92$ & 1752 & 15.6 & 13.0 & 13.2 & 10.7 \\
\hline 7 & $9-02-92$ & 2042 & 13.5 & 12.4 & 13.1 & 10.4 \\
\hline 8 & $g-03-92$ & 0020 & 35.5 & 8.3 & 9.7 & 10.9 \\
\hline
\end{tabular}




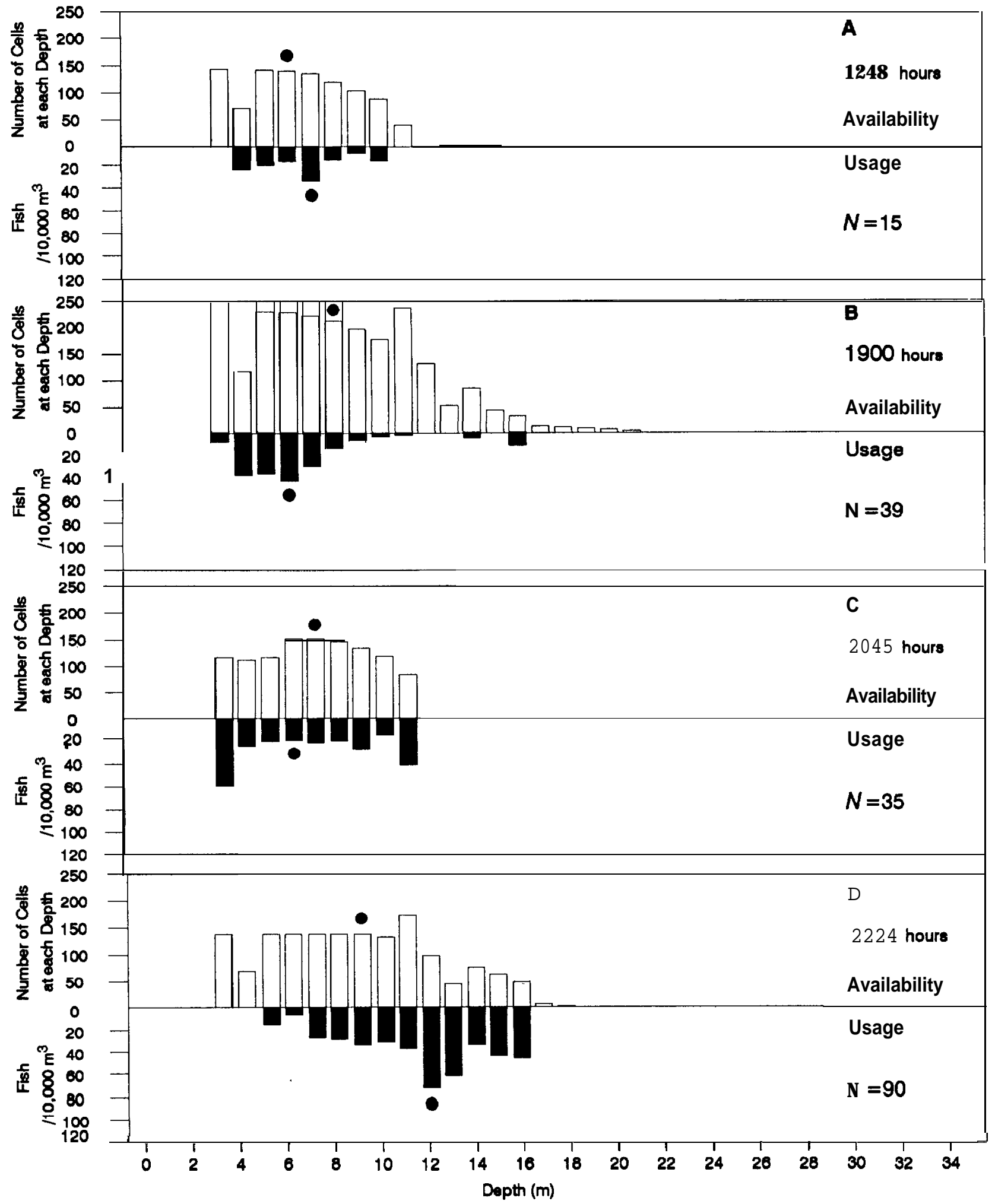

Figure 4.- Frequency histograms of available depth cells and associated fish density by depth for hydroacoustic surveys performed in McNary Reservoir, 1992. Medians are denoted as (•). 
(Figure 5). Exceptions to this were very high densities at the highest velocities.

The frequency distribution of fish relative to depth strata sampled differed between transects surveyed during the day and those surveyed at night. In the transects sampled during the day starting at 1200 and 1753 hours, the frequency of depth cells selected by fish was not significantly different from a random distribution ( $P>0.05$; Table 3$)$. The depth cells selected by fish on transects starting at 2042 and 0020 hours were not randomly distributed $(P<0.05$; Table 3$)$.

The depths selected by fish and those available in the reservoir cross section were significantly different ( $P$ C 0.05 ; Table 3). Although the median depth of the transects surveyed was similar in all transects, $10.4-10.9 \mathrm{~m}$, the median depth of fish detected shifted from $15.5 \mathrm{~m}$ at midday to $9.7 \mathrm{~m}$ for transects starting near midnight (Table 4; Figure 6).

\section{Discussion}

We assumed that most hydroacoustic targets located in McNary Reservoir during July were subyearling chinook salmon and most targets located in John Day Reservoir during August and early September were American shad. Species composition of trawl catches, fish passage indices, and the limits we used on target strengths of $-58 \mathrm{db}$ to $-46 \mathrm{db}$ support these conclusions.

Although the total volume of water sampled during 1992 hydroacoustic surveys was large, encounters with target fish were quite low, especially during the early summer surveys conducted in McNary Reservoir. This is partially due to overall fish densities in the system at the time of sampling. However, it is also a result of the echo sounder beam structure, narrow at the surface and increasing in width with depth, resulting in inefficient sampling of the upper three meters of the water column. To accurately evaluate this portion of the water column an emphasis on improved side looking techniques or modifications in equipment need to be tested and evaluated. The inability to accurately sample shallow nearshore areas is also a concern. The importance of these areas of the reservoirs in regards to subyearling chinook salmon migration and rearing is of interest.

The water velocities that fish were located at were not random and did not reflect availability. In most groups of transects we found that frequency of velocities selected by fish were significantly different from random. Furthermore, the water velocities selected by fish were significantly different from the expected frequency based on water velocities available in the reservoir cross sections. The range of water velocities measured was relatively narrow in all transects surveyed (<50 cm/s). 


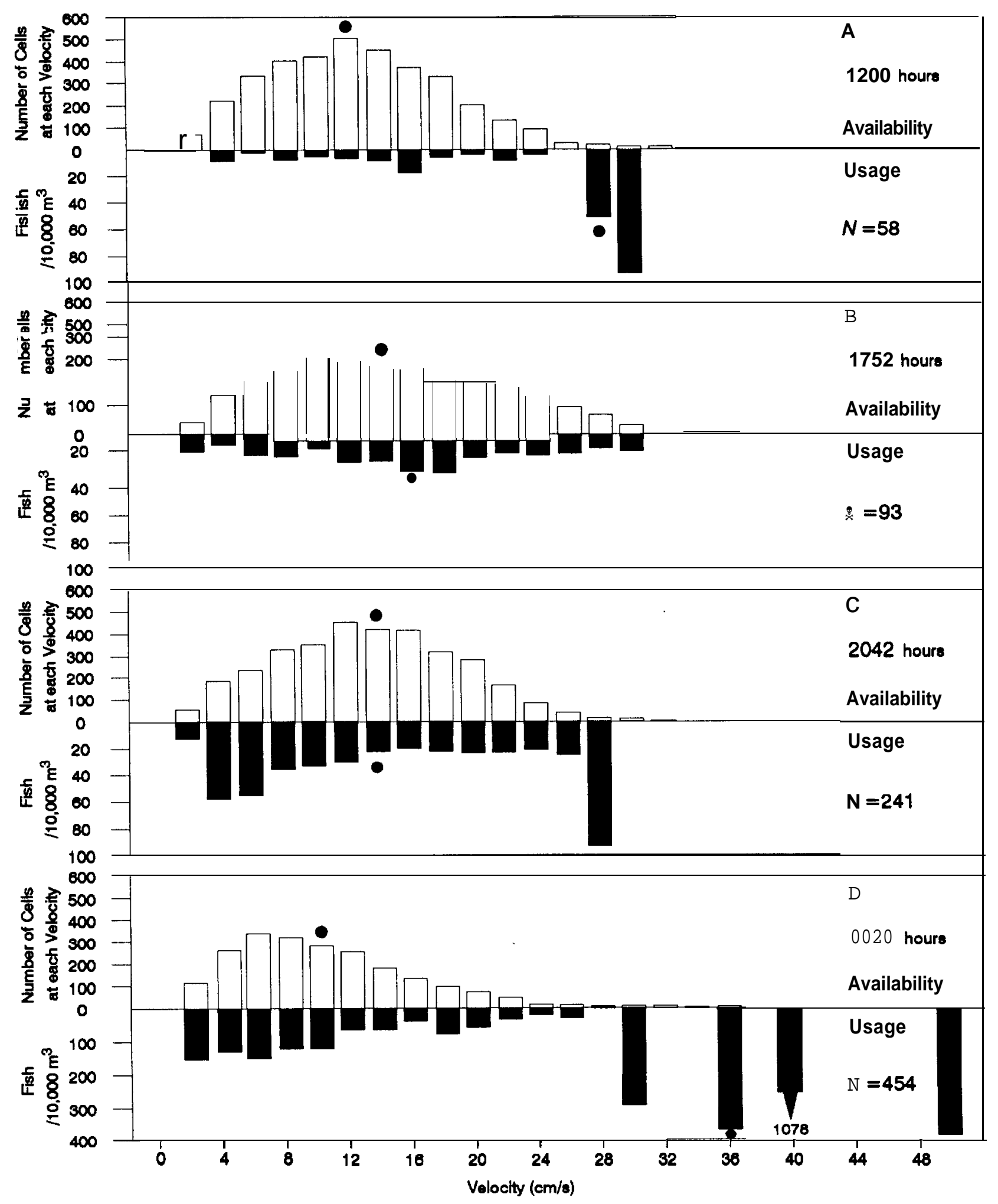

Figure 5.- Frequency histograms of available velocity cells and associated fish density by velocity for hydroacoustic surveys performed in John Day Reservoir, 1992. Medians are denoted as (๑). 

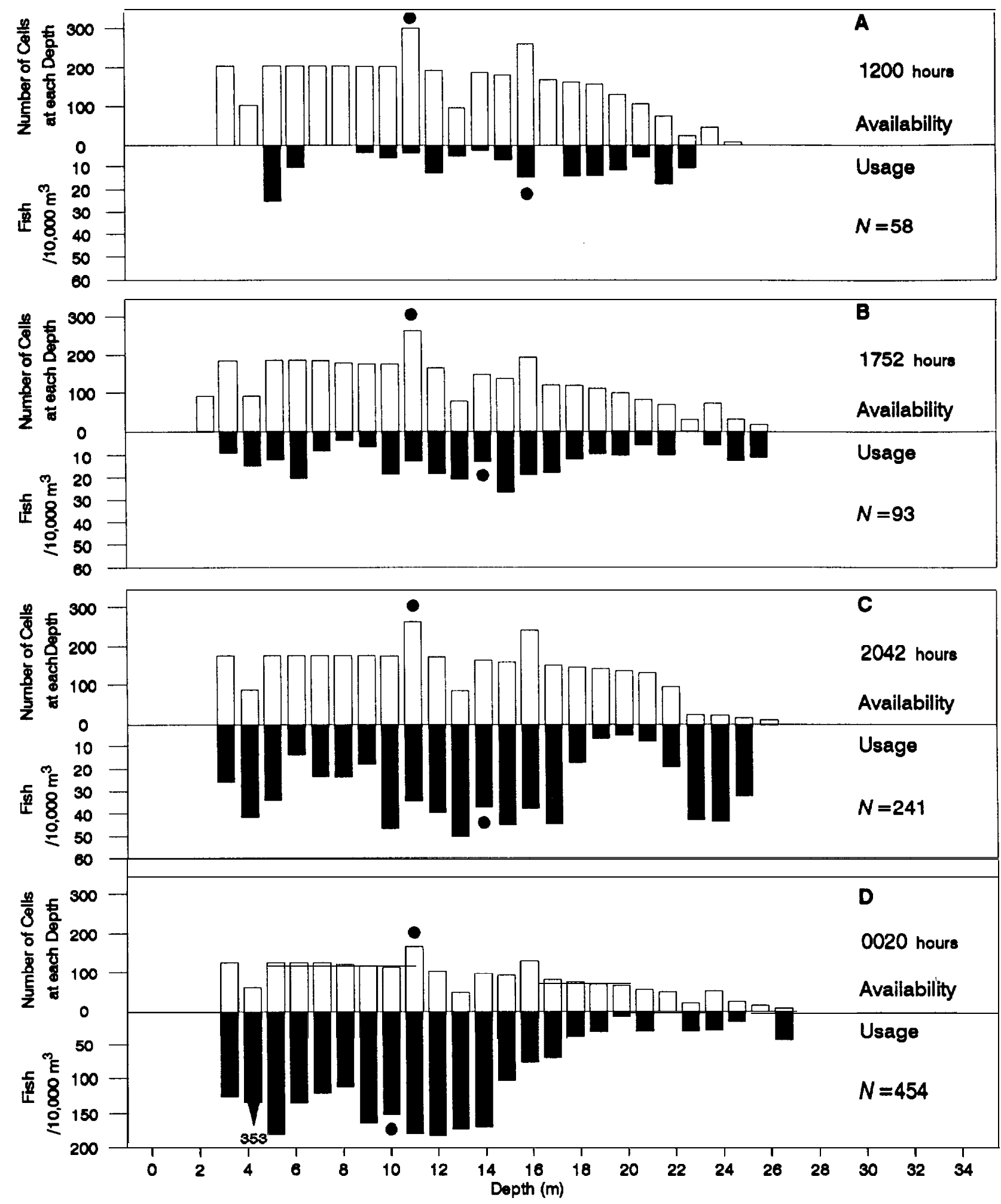

Figure 6.- Frequency histograms of available depth cells and associated fish density by depth for hydroacoustic surveys performed in John Day Reservoir, 1992. Medians are denoted as (॰). 
Discerning patterns of biological significance within this relatively narrow range of water velocities may be difficult.

In summary, we integrated and deployed a system using a hydroacoustic fish stock assessment system to locate subyearling chinook salmon in reservoirs, an ADCP to measure water velocities, and a GPS to provide locations and night navigation. Data presented in this chapter are preliminary, but representative of the data collected during 1992 field work. Concerns about equipment capabilities, sampling techniques, and data analysis will continue to be addressed. 


\section{References}

Berggren, T.J., and M.J. Filardo. 1993. An analysis of variables influencing the migration of juvenile salmonids in the Columbia River Basin. North American Journal of Fisheries Management 13:48-63.

Faurot, D.A., L.C. Stuehrenberg, and C.W. Sims. 1982. Migrational characteristics of juvenile salmon and steelhead trout in the Columbia River system, 1981. Report to U.S. Army Corps of Engineers, Contract DACW57-81-F-0342, Portland, Oregon.

Giorgi, A. 1991. The migrational characteristics of chinook salmon emanating from the Snake River Basin. Don Chapman Consultants, Inc., Report to ESA record, National Marine Fisheries Service, Portland, Oregon.

Miller, D.R., and C.W. Sims. 1983. Effects of flow on the migratory behavior of juvenile fall and summer chinook salmon in John Day Reservoir. Report to Bonneville Power Administration, Contract DE-A179-81BP-27602, Portland, Oregon.

Miller, D.R., and C.W. Sims. 1984. Effects of flow on the migratory behavior and survival of juvenile fall and summer chinook salmon in John Day Reservoir. Report to Bonneville Power Administration, Contract DE-A179-83BP39645, Portland, Oregon.

Raymond, H.L. 1969. Effect of John Day Reservoir on the Migration Rate of Juvenile Chinook Salmon in the Columbia River. Transactions of the American Fisheries Society $98: 513-514$.

Raymond, H.L. 1988. Effects of Hydroelectric development and fisheries enhancement on spring and summer chinook salmon and steelhead in the Columbia River Basin. North American Journal of Fisheries Management 8:1-24, 1988.

Sims, C.W., J.G. Williams, D.A. Faurot, R.C. Johnsen, and D.A. Brege. 1981. Migrational characteristics of juvenile salmon and steelhead trout in the Columbia River Basin and related passage research at John Day Dam, Volumes I and II. Report to U.S. Army Corps of Engineers, Contracts DCW57-80-F-0394 and DACW68-78-C-0051, Portland, Oregon.

Thorne, Dr. R.E., C.J. MCClain, J. Hedgepeth, E.S. Kuehl, and J. Thorne. 1992. Hydroacoustic surveys of the distribution and abundance of fish in Lower Granite Reservoir, 1989-1990. Report to U.S. Army Corps of Engineers, Contract

DACW68-C-0022, Walla Walla, Washington. 
Zar, J.H. 1984. Biostatistical Analysis, 2nd edition. PrenticeHall, Inc., Englewood Cliffs, New Jersey. 


\section{CHAPTER EIGHT}

Osmoregulatory Performance and Marking of Subyearling Chinook Salmon at McNary Dam to Estimate Adult Contribution

by

K.F. Tiffan and D.W. Rondorf National Biological Survey

Columbia River Research Laboratory

Cook, Washington 98605, USA

and

P.G. Wagner

Washington Department of Fisheries

Plymouth, Washington 99346, USA 


\section{Introduction}

Research conducted at McNary Dam from 1981 to 1983 determined that subyearling chinook salmon Uncorhynchus tshawytscha which emigrated earlier in the summer exhibited greater adult contribution than did those emigrating later in the summer (Giorgi et al. 1990). No physical or biological factor could be isolated as a causal factor for this phenomenon even though a primary objective of the study was to examine the influence of flows on juvenile emigration and survival. Giorgi et al. (1990) attributed this failure to an inability to recover sufficient numbers of marked fish at John Day Dam to estimate their travel time through John Day Reservoir and the interaction among flow, temperature, fish size, physiological development, and origin of the fish.

This study task was initiated in an attempt to resolve the questions pertaining to the influence of summer flows on the emigration of subyearling chinook salmon and their contribution as adults. The primary objectives for this second year of study were to mark and release sufficient numbers of subyearling chinook salmon at McNary Dam to estimate their travel time through John Day pool and to determine if released groups remained temporally discrete during emigration. Another objective was to describe the physiological development of fish marked and released at McNary Dam and to relate that to travel time and future adult returns.

\section{Methods}

\section{Marking and Release}

Juvenile subyearling chinook salmon were collected from the juvenile fish collection facility at McNary Dam. The dam is equipped with traveling screens to divert juvenile fish from the turbine intakes into gatewells and to raceways. Fish entering the collection facility were sub-sampled by operation of a timed gate in the conduit moving fish to the holding raceways. Each group of fish was collected by repeated sub-sampling during a 24 $h$ period starting at 0700 hours. The sub-sample rate ranged from 5\% to $20 \%$ of the total number of fish diverted.

Subyearling chinook salmon were marked with coded wire tags (CWT) and branded with cold brands (Jefferts et al. 1963; Mighell 1969). Fish were anesthetized with a preanesthetic of benzocaine (ethyl P-aminobenzoate) and an anesthetic of tricaine methanesulfonate (MS-222) similar to that described by Matthews (1986). Juvenile fish were then sorted by species and marked with CWT and cold brands. Three segments of the emigration were marked; early, middle, and late. For each segment of the 
migration, three CWT codes were used resulting in a total of nine CWT codes released in 1992. During each day of marking, fish were marked with cold brands using a unique combination of a character, location, and rotation. The cold brand identified the fish for subsequent determination of migration time from McNary Dam to John Day Dam. Marked fish were released into the fish bypass system at McNary Dam between 2200 and 2300 hours on the day of marking. At John Day Dam juvenile salmon were collected using two air-lift pumps (Brege et al. 1990) and the brands on recaptured fish were recorded.

The marking program included measures to ensure the quality of subyearling chinook salmon released at McNary Dam. Fish that; were previously branded or adipose fin clipped and CWT tagged, descaled, or had injuries likely to result in mortality were not marked (Wagner 1993). Fish with fork lengths < $55 \mathrm{~mm}$ were also not marked. One hundred fish per day were held for $48 \mathrm{~h}$ to measure delayed mortality and coded wire tag loss from the first and second replicates and about 50 fish per day were held from the third replicate. Fish surviving the delayed mortality test were transported downstream by barge or truck to prevent confounding of migration time estimates to John Day Dam.

Travel time of branded replications of fish was estimated to the nearest day by the method used by the Fish Passage Center i.e., the difference between the median date of release at McNary Dam and the date nearest the median date of recovery based on the passage indices at John Day or Bonneville dams. However, we only estimated travel time to the nearest day and did not interpolate to the nearest tenth of a day. Flow and temperature during travel time was estimated by averaging the discharge and temperature at John Day Dam from the day after fish release at McNary Dam through the median day of recovery at John Day Dam. Since recapture data were not normally distributed, nonparametric tests were used in statistical analyses.

\section{Physiology}

Samples were collected for gill $\mathrm{Na}^{+}, \mathrm{K}^{+}$-adenosine triphosphatase (ATPase) analysis from Priest Rapids state Fish Hatchery brand groups and from wild subyearling fall chinook salmon in the Hanford Reach of the Columbia River to assess smoltification of premigrants. Priest Rapids fish were sampled before release and Hanford fish were sampled coincidentally with a Washington Department of Fisheries marking study. Gill samples were collected again from Priest Rapids and Hanford brand groups at McNary Dam to measure ATPase activities of emigrants.

Twenty-four-hour seawater challenges were employed to evaluate the physiological status of emigrating subyearling chinook salmon marked at McNary Dam. The general procedures of 
the seawater challenges followed Blackburn and Clarke (1987). Recirculating flow-through systems were used for challenged and control fish. The seawater system was composed of eight plastic 80-L containers which drained into a sump reservoir and a pump recirculated salt water from the sump to the plastic containers. The control system was identical to the seawater system except two containers were used. Chillers were placed in sump reservoirs to maintain water temperature at $18.3^{\circ} \mathrm{C}$. Diaphragm pumps and air stones supplied air to each tank.

Actively emigrating subyearling chinook salmon were collected at the McNary Dam fish collection facility coincidentally with marking. Three separate challenges were conducted to characterize the seawater adaptability of migrants during the early, middle, and late portions of the outmigration. Random samples of 10 anesthetized fish were weighed, measured (FL), and distributed to each tank. Fish were allowed to acclimate for $24 \mathrm{~h}$ prior to being challenged.

Artificial sea salt was dissolved and added to the sump reservoir of the seawater system to infuse salt water into the tanks without handling or disturbing the fish. A desired salinity of 30 parts-per-thousand was usually achieved within one hour. Unchallenged control fish were maintained in fresh water.

At the end of a 24-h challenge, fish were immobilized in their tanks with $30 \mathrm{mg} / \mathrm{L}$ MS222. Anesthetized fish were weighed, measured, rinsed in fresh water., and their tails blotted dry before being severed. Blood was collected from the caudal artery in ammonium heparinized Natelson tubes, centrifuged, and the plasma was frozen immediately in liquid nitrogen. In addition, gill filaments were collected for determination of $\mathrm{Na}^{+}, \mathrm{K}^{+}-\mathrm{ATPase}$ activity.

Blood plasma was analyzed for $\mathrm{Na}^{\prime}$ and $\mathrm{K}^{+}$by flame photometery. Plasma cortisol was analyzed by radioimmunoassay (Redding et al. 1984) and gill $\mathrm{Na}^{+}, \mathrm{K}^{+}$-ATPase activity was measured using a microassay (Schrock et al. 1994). Group means were calculated for control and test fish for the three challenges. Means were compared between challenges using analysis of variance (ANOVA) and Tukey's test while withinchallenge comparisons were made using t-tests by the Cochran-Cox approximation for plasma $\mathrm{Na}^{\prime}$ and $\mathrm{K}^{+}$and t-tests for plasma cortisol and gill ATPase activity. The significance level for all tests was $P<0.05$. 
Results

\section{Marking, Release, and Recapture}

The median date of subyearling chinook salmon emigration past McNary Dam in 1992 was 29 June (Figure 1), which is 4 days earlier than the 1984-90 median. The 10\% passage was four days later and the 90\% passage was four days earlier than the 1984-90 mean (Fish Passage Center 1993). Based on recaptures of wild subyearling chinook salmon that were freeze branded, tagged with passive integrated transponders (PIT) and released in the Hanford reach on 8 June (median date), 10\%, 50\%, and 90\% passage at McNary Dam occurred on 25 June, 3 July, and 18 July, respectively. The median dates of passage at McNary Dam of branded subyearling fall chinook salmon released from Priest Rapids State Fish Hatchery between 12 and 24 June ranged from 30 June to $6 \mathrm{July}$. The median date of passage for branded subyearling summer chinook salmon released on 19 June from Wells State Fish Hatchery was 28 July. A total of 1,549 subyearling chinook were PIT tagged and released from 15 June to 14 August for the first time from Rock Island Dam in 1992. Of these, 4.9\% were detected at McNary Dam (Fish Passage Center 1993). The 10, 50, and 90\% passage dates of all hatchery fish combined at McNary Dam were 26 June, $2 \mathrm{July}$, and $18 \mathrm{July}$. Passage dates at McNary Dam indicate that migration timing was similar for hatchery fish and wild fish produced in the Hanford Reach.

A total of 105,250 subyearling chinook salmon collected at McNary Dam were freeze branded, coded wire tagged, and released in the tailrace (Table 1; Appendix 9). An additional 2,750 marked fish were transported after being retained for $48 \mathrm{~h}$ to estimate delayed mortality and CWT loss, which ranged from 0.6 to 0.7\%. The group of 35,095 early migrants were marked with 9 unique brands from 16 to 24 June when the cumulative passage index increased from 5\% to $20 \%$. The middle group of 35,052 emigrants were marked with 10 unique brands from 2 to 11 July when the passage index increased from 63\% to $84 \%$. The late group of 35,103 emigrants were marked with 14 unique brands from 17 to 30 July when the passage index increased from 94\% to 97\%.

Columbia River flows at McNary Dam decreased from about 170 thousand cubic feet KCFS in late August to $22^{\circ} \mathrm{C}$ (Figure 1$)$. per second (KCFS) in early June to about 90 while water temperature increased from $16^{\circ} \mathrm{C}$ the 40 year average.

The number of subyearling chinook salmon recaptured at John Day Dam ranged from 36 to 118 fish for the nine CWT replications and from 128 to 324 for the early, middle, and late groups

(Figure 2; Table 2). Estimated travel times were 15, 21, and 15 


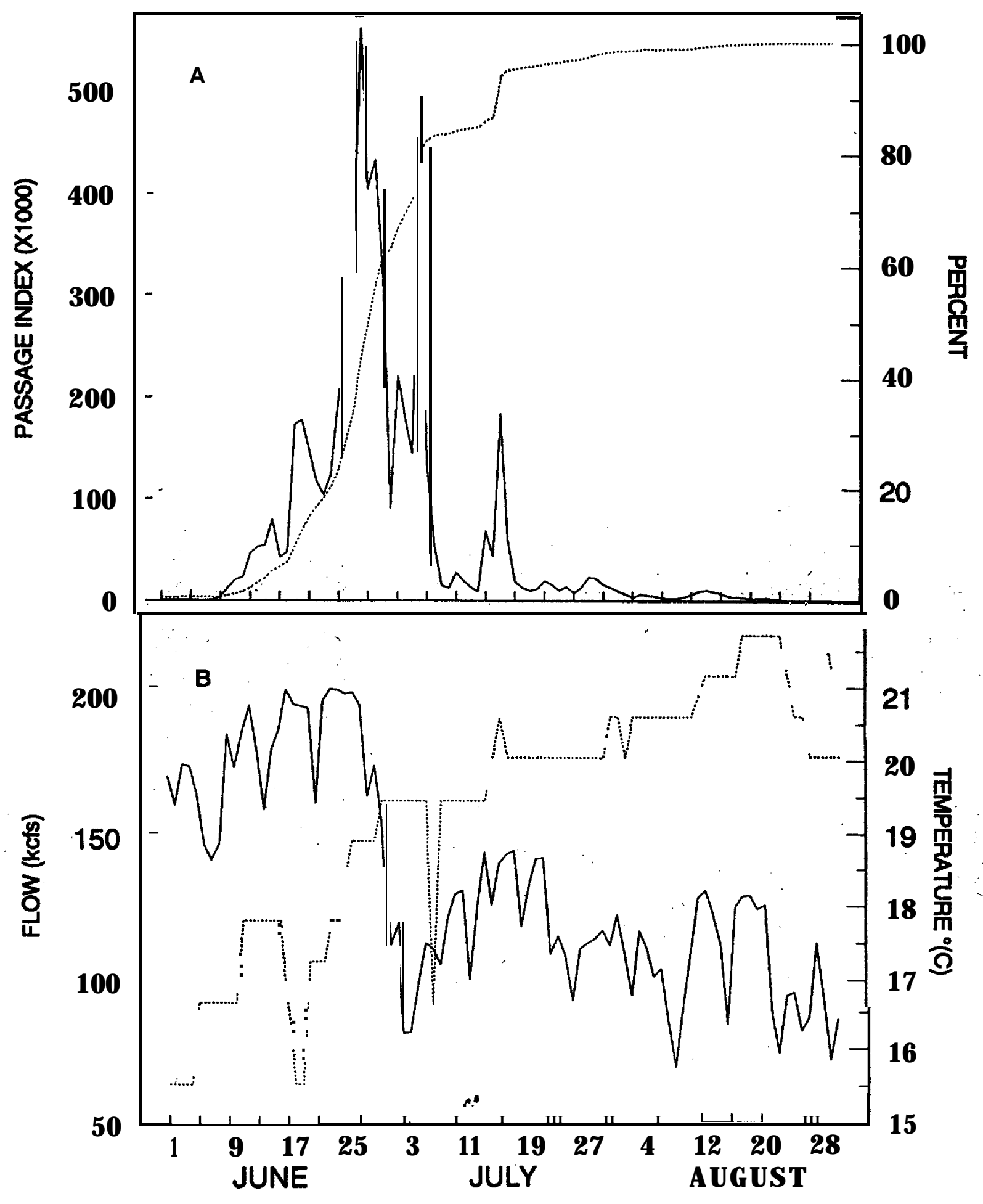

Figure 1.-Daily (solid line) and cumulative (dotted line) passage index (x1000) of subyearling chinook salmon (A) and daily flow (solid line) and temperature (dotted line: B) at McNary Dam, 19-92. 
Table 1 .-Date, coded wire tag (CWT) code, and number of subyearling chinook salmon released in the McNary Dam tailrace and the number of fish held for $48 \mathrm{~h}$ with their tag loss and mortality prior to transportation, 1992.

\begin{tabular}{|c|c|c|c|c|c|c|c|}
\hline Date & $\begin{array}{l}\text { CWT } \\
\text { Code }\end{array}$ & $\&$ & $\begin{array}{l}\text { Marked } \\
\text { Released }\end{array}$ & $\begin{array}{l}\text { Marked } \\
\& \text { Held }\end{array}$ & Mortality & $\begin{array}{l}\text { Tag } \\
\text { Loss }\end{array}$ & $\begin{array}{c}\text { Percent } \\
\text { Loss }\end{array}$ \\
\hline Jun $16-18$ & $29-52$ & & 11,767 & 300 & 0 & 0 & 0 \\
\hline Jun $19-21$ & $29-54$ & & 11,259 & 300 & 3 & 1 & 0.3 \\
\hline Jun $22-24$ & $29-53$ & & 12,069 & 305 & 0 & 0 & 0 \\
\hline Sub-Total & & & 35,095 & 905 & 3 & 1 & 0.1 \\
\hline Jul 2-4 & $29-51$ & & 11,700 & 300 & 2 & 0 & 0 \\
\hline Jul 5-7 & $29-50$ & & 11,786 & 300 & 0 & 0 & 0 \\
\hline Jul 8-11 & $29-49$ & & 11,566 & 400 & 4 & 0 & 0 \\
\hline Sub-Total & & & 35,052 & 1,000 & 6 & 0 & 0 \\
\hline Jul $17-18$ & $29-48$ & & 11,386 & 200 & 2 & 10 & 5.0 \\
\hline Jul 19-25 & $29-46$ & & 11,766 & 350 & 8 & 5 & 1.4 \\
\hline Jul 26-30 & $29-47$ & & 11,951 & 295 & 1 & 0 & 0 \\
\hline Sub-Total & & & 35,103 & 845 & 11 & 15 & 1.8 \\
\hline Total & & & 105,250 & 2,750 & 20 & 16 & 0.6 \\
\hline
\end{tabular}




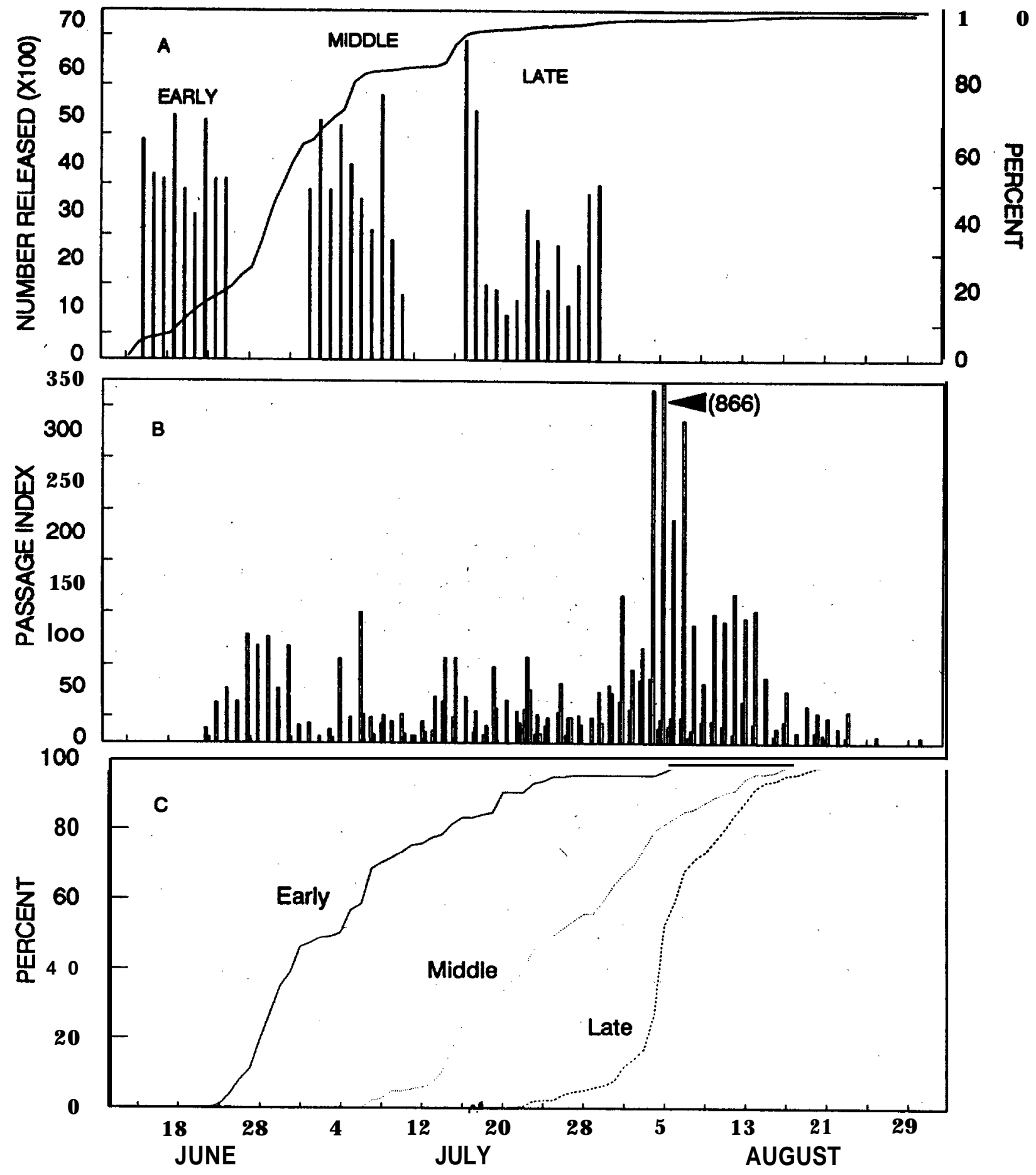

Figure 2.-Number of subyearling chinook salmon marked and released at McNary Dam with cummulative percent passage index and the passage index of early, middle, and late emigrating marked groups (B) and the cummulative percent frequency of each group (C) recovered at John Day Dam, 1992. 
Table 2.-Median dates and number of subyearling chinook salmon released at McNary Dam and the number recovered, passage index (PI), and percent detected ( $\left(\frac{\circ}{\circ}\right)$ at John Day and Bonneville dams, 1992.

\begin{tabular}{|c|c|c|c|c|c|c|c|c|c|c|c|c|}
\hline \multirow{2}{*}{ 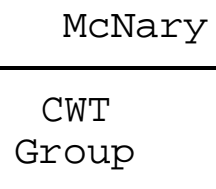 } & \multicolumn{2}{|c|}{ Dam Release } & \multicolumn{3}{|c|}{ Recovery at } & \multicolumn{2}{|c|}{ t John Day } & \multicolumn{3}{|c|}{ Recovery at } & \multicolumn{2}{|c|}{ Bonnevile } \\
\hline & $\begin{array}{l}\text { Med. } \\
\text { Date }\end{array}$ & $\begin{array}{l}\text { Num- } \\
\text { ber }\end{array}$ & & $\begin{array}{l}\text { Med. } \\
\text { Date }\end{array}$ & $\begin{array}{l}\text { Num- } \\
\text { ber }\end{array}$ & PI & $\frac{\circ}{0}$ & & $\begin{array}{l}\text { Med. } \\
\text { Date }\end{array}$ & $\begin{array}{l}\text { Num- } \\
\text { ber }\end{array}$ & PI & $\div$ \\
\hline $29-52$ & 17 Jun & 11,767 & 28 & Jun & 46 & 511 & 4.3 & 29 & Jun & 31 & 93 & 0.8 \\
\hline $29-54$ & 20 Jun & 11,259 & 5 & Jul & 36 & 336 & 3.0 & 2 & Jul & 75 & 214 & 1.9 \\
\hline Early & 20 Jun & 35,095 & 5 & Jul & 128 & 1,278 & 3.6 & 2 & Jul & 180 & 509 & 1.5 \\
\hline $29-51$ & $3 \mathrm{Jul}$ & 11,700 & 17 & Jul & 39 & 365 & 3.1 & 21 & Jul & 55 & 106 & 0.9 \\
\hline Middle & $6 \mathrm{Jul}$ & 35,052 & 27 & Jul & 140 & 1,225 & 3.5 & 21 & Jul & 253 & 510 & 1.5 \\
\hline $29-48$ & 17 Jul & 11,386 & 5 & Aug & 97 & 767 & 6.7 & 7 & Aug & 60 & 130 & 1.1 \\
\hline $29-46$ & $23 \mathrm{Jul}$ & 11,766 & 7 & Aug & 109 & 949 & 8.1 & 20 & Aug & 60 & 100 & 0.8 \\
\hline $29-47$ & $29 \mathrm{Jul}$ & 11,951 & 10 & Aug & 118 & 943 & 7.9 & 17 & Aug & 120 & 236 & 2.1 \\
\hline Late & $23 \mathrm{Jul}$ & 35,103 & 7 & Aug & 324 & 2,659 & 7.6 & 16 & Aug & 240 & 466 & 1.4 \\
\hline
\end{tabular}


days for the early, middle, and late groups, respectively. The Kruskal-Wallis test indicated the time of emigration for the three groups past John Day Dam was significantly different $\left(\mathrm{X}^{2}=\right.$ 196.6) and Tukey's test indicated all three groups were significantly different from each other.

The number of fish recaptured at Bonneville Dam ranged from 31 to 120 for the nine CWT replications and 180 to 253 for the three groups (Table 2). Emigration time for the three groups past Bonneville Dam was significantly different $\left(X^{2}=68.62\right)$ and each group was different from each other. The median dates of recapture for the replications at John Day and Bonneville dams indicated the fish traveled rapidly through the Dalles and Bonneville reservoirs compared to travel time through John Day reservoir. Travel time was not significantly correlated with flow, temperature, gill ATPase activity, median release date, or fork length (Table 3).

\section{Physiology}

Gill ATPase activity of premigrants from Priest Rapids State Fish Hatchery and from the Hanford Reach was low but rose substantially by the time of recapture at McNary Dam. Mean gill ATPase activities of prerelease brand groups at Priest Rapids on 11 and 17 June were 9.2 and $8.6 \mu$ mol $\mathrm{Pi} /(\mathrm{mg}$ protein)/h, respectively. These same brand groups were recaptured at McNary Dam from 27 June to $15 \mathrm{July}$ and had mean gill ATPase activities of 27.1 and $26.8 \mu \mathrm{mol} \mathrm{Pi} /$ (mg protein)/h. Subyearling chinook salmon branded in the Hanford reach on 3 and 10 June had gill ATPase activities of 11.5 and $14.0 \mu$ mol Pi/(mg protein)/h. These fish were collected at McNary Dam from 21 June to 28 July and had mean gill ATPase activities of 31.0 and $31.4 \mu \mathrm{mol} \mathrm{Pi} /(\mathrm{mg}$

protein)/h. Gill ATPase activities of migrants marked at McNary Dam ranged from 20.0 to 34.3 in 1992 while in 1991 levels ranged from 14.6 to $30.3 \mu \mathrm{mol} \mathrm{Pi} /(\mathrm{mg}$ protein)/h (Figure 3).

All subyearling chinook salmon used in seawater challenges exhibited the silvery appearance of smolts. Group means of plasma $\mathrm{Na}^{\prime}$ of challenged fish were $153.2 \mathrm{mmol} / \mathrm{L}$ for the early challenge, 150.3 for the middle, and 153.6 for the late challenge (Table 4, Figure 4). Of the 223 fish challenged only 5 died during testing.

ANOVA of plasma Na' values from the early challenge were significantly different than those of the middle, but not the late challenge. The middle and late challenge plasma $\mathrm{Na}^{\prime}$ concentrations were not different from each other. Control values from the early challenge were significantly different from the middle and late challenge but there was no difference between the middle and late challenges for plasma $\mathrm{Na}$ '. Comparisons within challenges showed that seawater challenged fish had 
Table 3.-Correlation of subyearling chinook salmon travel time from McNary Dam to John Day Dam with median release date, flow, temperature, ATPase activity, and fork length (FL) of coded wire tagged (CWT) groups, 1992.

\begin{tabular}{|c|c|c|c|c|c|c|}
\hline $\begin{array}{c}\text { CWT } \\
\text { Group }\end{array}$ & $\begin{array}{l}\text { Travel } \\
\text { Time (d) }\end{array}$ & $\begin{array}{l}\text { Median } \\
\text { Date }\end{array}$ & $\begin{array}{c}\text { Flow } \\
\text { (kcfs) }\end{array}$ & Temp. & $\begin{array}{c}\text { ATPase } \\
\text { Activity }\end{array}$ & $\begin{array}{c}\mathrm{FL} \\
(\mathrm{mm})\end{array}$ \\
\hline $\begin{array}{l}\text { Early } \\
29-52\end{array}$ & 11 & 17 June & 193 & 18.4 & 27.2 & 110 \\
\hline $29-54$ & 15 & 20 June & 156 & 18.3 & 22.0 & 108 \\
\hline $29-53$ & 15 & 23 June & 140 & $1 a .3$ & 27.6 & 106 \\
\hline $\begin{array}{c}\text { Middle } \\
29-51\end{array}$ & 14 & 3 July & 121 & la. 7 & 31.5 & 106 \\
\hline $29-50$ & 26 & $6 \mathrm{July}$ & 123 & 19.8 & 34.3 & 106 \\
\hline $29-49$ & 23 & 9 July & 125 & 20.0 & 30.6 & 109 \\
\hline $\begin{array}{l}\text { Late } \\
29-48\end{array}$ & 19 & 17 July & 118 & 20.7 & 23.6 & 114 \\
\hline $29-46$ & 15 & 23 July & 112 & 20.9 & 20.5 & 118 \\
\hline $29-47$ & 12 & 29 July & 104 & 20.9 & 20.0 & 125 \\
\hline$r$ & & 0.123 & -0.333 & 0.267 & 0.584 & -0.385 \\
\hline
\end{tabular}




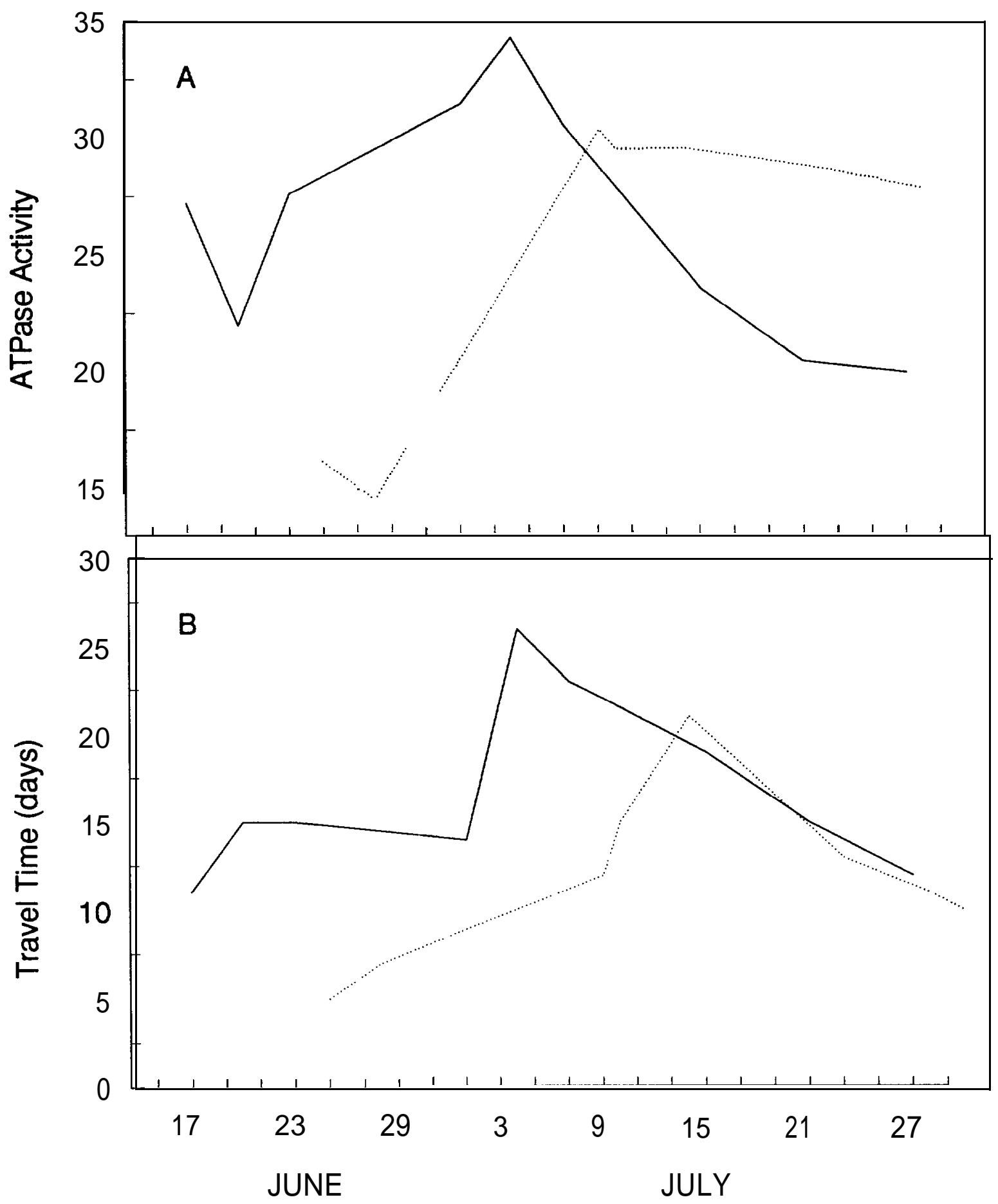

Figure 3.-Gill ATPase activity (A) and travel time to John Day Dam (B) calculated from median date of release of groups of subyearling chinook salmon marked at McNary Dam in 1991 (dotted line) and 1992 (solid line). 
Table 4.-Mean plasma Na' (mmol/L), plasma cortisol ( $\mathrm{ng} / \mathrm{ml})$, and gill ATPase activity ( $\mu \mathrm{mol} \mathrm{Pi} /(\mathrm{mg}$ protein)/h) from subyearling fall chinook migrants subjected to 24-h seawater challenges at McNary Dam, 1992.

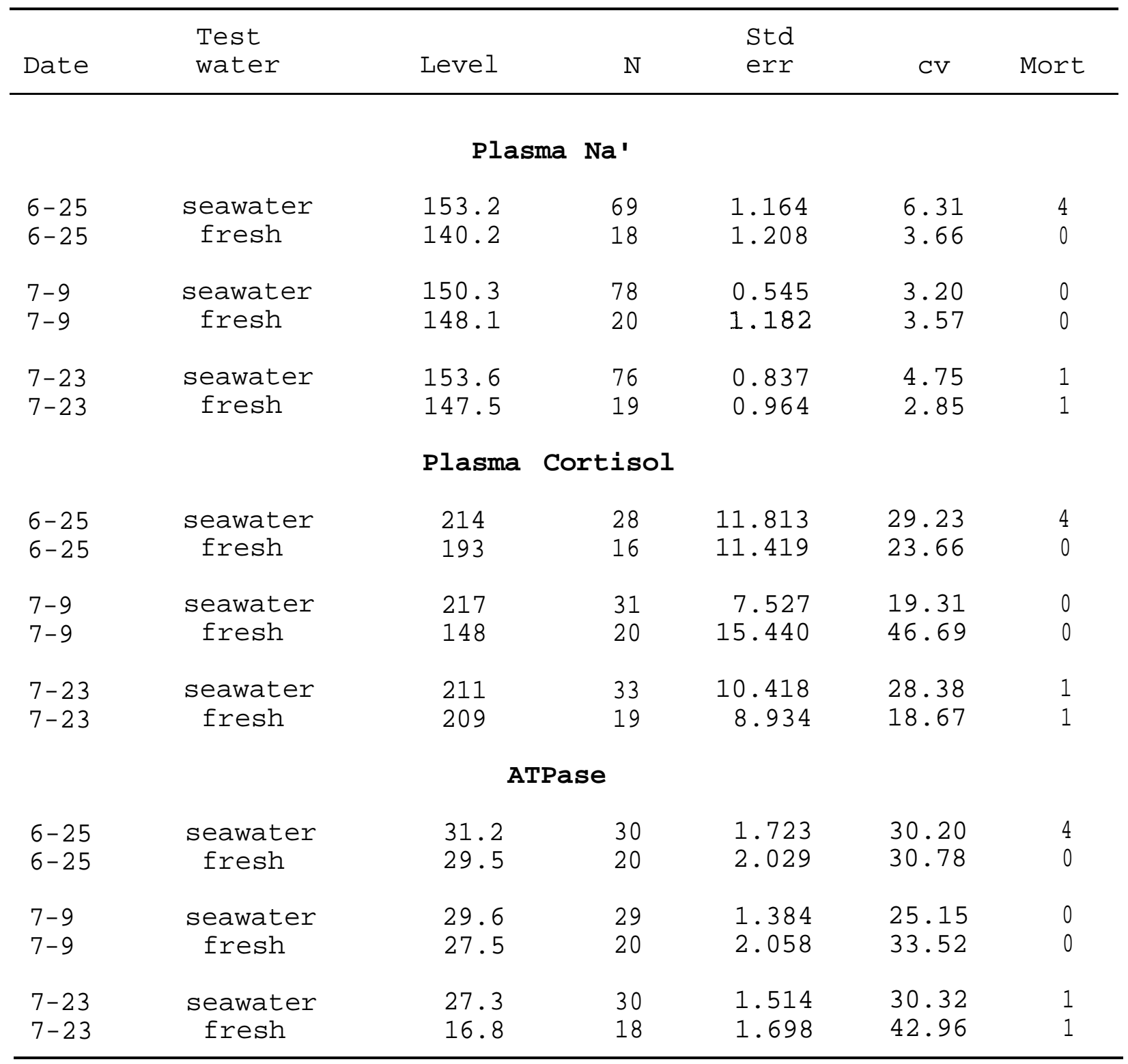



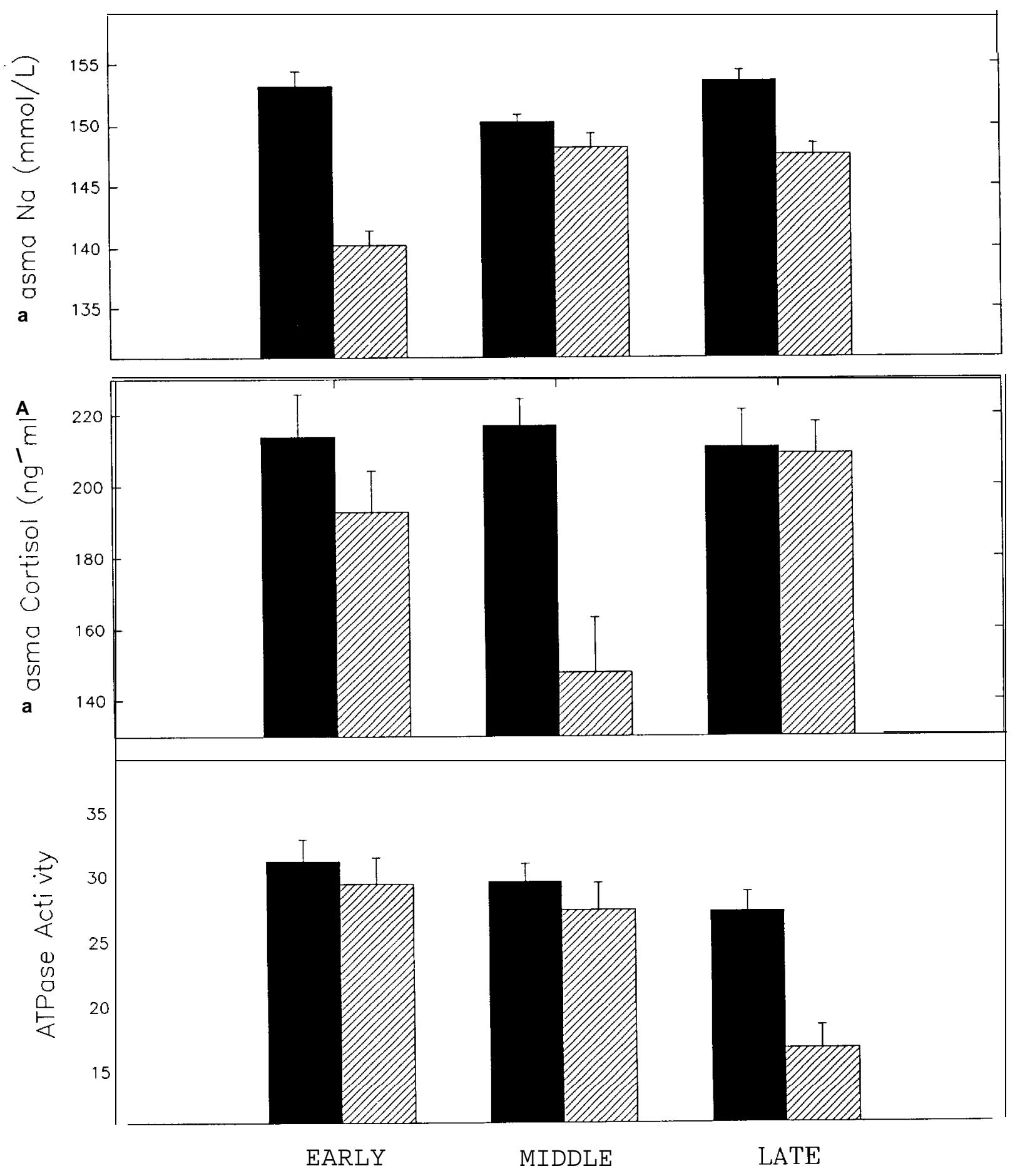

\section{Seawater QIIIA Control}

Figure 4 .-Physiological responses, with standard error bars, of subyearling chinook salmon exposed to seawater and fresh water at McNary Dam during the early (25 June), middle (9 July), and late (23 July) portions of the 1992 outmigration. 
significantly higher plasma $\mathrm{Na}$ ' values than control fish in the first and third challenges but not in the second challenge.

There was a small decrease in plasma $\mathrm{K}^{+}$concentration from the early to late portion of the run but no differences were found between challenged and control fish.

There were no significant differences in plasma cortisol values of challenged fish between any portions of the outmigration. Mean plasma cortisol values of challenged fish showed a slight decrease from $219 \mathrm{ng} / \mathrm{ml}$ in the early portion of the run to $210 \mathrm{ng} / \mathrm{ml}$ in the late part of the run (Table 4, Figure 4). Control fish values were slightly lower than challenged fish values during all challenges. Low plasma cortisol values of control fish from the middle challenge resulted in significant differences in any comparison involving this group, otherwise, there were no differences between control values or between challenge and control values. Plasma cortisol was correlated with plasma $\mathrm{Na}^{\prime}$ when cortisol from fish in seawater were combined $(r=0.407)$. No correlations existed between plasma cortisol and plasma Na', gill ATPase activity, length, or weight in control fish.

ATPase activities were typical of smolted fish, but showed a slight decline from the early to late portions of the outmigration (Table 4, Figure 4). Seawater challenged fish had higher activities than control fish, but were not significantly different except during the late challenge. Seawater gill ATPase activities were not significantly different over time, but low activities from the late control group resulted in significant differences in any comparison involving this group. In seawater fish, ATPase activity was significantly correlated with length ( $r$ $=-0.285)$ and weight $(r=-0.266)$ and in control fish with plasma $\mathrm{K}^{+}(r=0.329)$.

\section{Discussion}

Travel time from McNary to John Day Dam was correlated with certain physical and physiological variables in 1991, but no significant correlations existed in 1992. The reason for this may be that travel times in 1992 showed no distinct pattern of either increasing or decreasing over time. This made the likelihood of obtaining any significant correlations involving travel time improbable, especially given the small sample sizes used in correlation analyses.

Estimated travel times of subyearling chinook salmon from McNary to John Day Dam did not follow the paradigm that travel time decreases with increased flow or the expectation that rapid travel time would be associated with relatively high gill ATPase activities. Travel times increased from the early to middle portions of the outmigration as flows decreased, but then became shorter during the late portion of the run as flows continued to 
decline. ATPase activity followed a similar trend (Figure 3). During the latter portion of the outmigration several factors such as increased water temperature, increased fish size, and stock differences may have contributed to this phenomenon. In addition, Skalski (1989) has shown that various assumptions related to passage index calculation at John Day Dam are often violated due to shifts in dam operations and subsequently may lead to biased travel time estimates. This may explain the seemingly contradictory results obtained in 1992 .

Subyearling chinook salmon migrating past McNary Dam during the early, middle, and late portions of the outmigration in 1992 appeared to be fully smolted and were physiologically adapted to sea water. Although statistical differences were found between plasma Na' values, biologically there appeared to be no trend in seawater adaptiveness. Fish in all three seawater tests performed equally well as evidenced by low mortality and ability to regulate plasma $\mathrm{Na}$ ' below $165 \mathrm{mmol} / \mathrm{L}$, the value given by Clarke and Shelbourn (1985) for characterizing chinook salmon smolts. Higher plasma $\mathrm{Na}^{\prime}$ values in challenged fish compared to freshwater control groups may be attributed to the requirement of more than $24 \mathrm{~h}$ to further lower plasma $\mathrm{Na}^{\prime}$ or else plasma $\mathrm{Na}^{\prime}$ is maintained at a higher equilibrium in sea water (Conte and Wagner 1965 ) .

Plasma cortisol has been implicated in the maintenance of water-electrolyte balance in hyperosmotic media, but its role in accomplishing this remains unclear (Hoar 1988). No relationship was established between plasma cortisol and seawater adaptiveness in subyearling chinook salmon challenged at McNary Dam. All significant differences in plasma cortisol comparisons involved the middle challenge control group which contained a number of comparatively low values from one tank. The reason for this is unknown. The rapid surge in plasma cortisol upon entry into sea water observed in coho salmon o. kisutch(Redding et al. 1984; Young et al. 1989) was not observed in subyearling chinook salmon challenged at McNary Dam. Plasma cortisol may have surged then returned to prechallenge levels before samples were collected 24 $h$ later. Alternatively, plasma cortisol levels elevated by stress induced by the McNary Dam collection facility may have minimized any seawater response. Plasma cortisol values of both challenged and control fish were high compared to the baseline value of $100 \mathrm{ng} / \mathrm{ml}$ given by Schreck et al. (1984) for unstressed fish in the system. However, fish should have recovered from collection stress in 24-48 h (Maule et al. 1988). Regardless of any stress confounding that may have affected challenge results, there were no differences between challenged and control levels, except during the second challenge, that would indicate a seawater response by plasma cortisol. 
The rapid rise in gill ATPase activity exhibited by Priest Rapids and wild Hanford fish was likely due to physiological change during emigration (Zaugg et al. 1985). Although gill ATPase activity declined during the latter part of the emigratiou fish were still able to adapt to sea water. Despite comparatively low activities in control fish during the late portion of the run, ATPase activities increased significantly upon seawater entry. This is consistent with the findings of other investigators (see review in Folmar and Dickhoff 1980) relating to sea water's stimulating effect on ATPase activity.

There appeared to be no relationship between seawater performance of subyearling chinook salmon and river flow and temperature at McNary Dam. However, gill ATPase activity declined during the seawater challenge period as river flows declined and water temperatures increased. The decrease in gill ATPase activities with increasing temperature, reviewed by Wedemeyer et al. (1980), may explain the gill ATPase activity decline in this study. In addition, the decline in gill ATPase activities may have resulted from smolts migrating after their physiological peak due to longer travel times caused by lower flows.

The rise and subsequent decline in gill ATPase activities of run-at-large fish sampled at McNary Dam was similar to the increase and subsequent decrease in travel time during the study period. The observed trend of increasing gill ATPase activities with increasing travel times was unexpected. The definition and cause for this pattern may be elucidated after collecting additional data in upcoming years. 


\section{References}

Blackburn, J., and W.C. Clarke. 1987. Revised procedure for the 24 hour seawater challenge test to measure seawater adaptability of juvenile salmonids. Canadian Technical Report of Fisheries and Aquatic Sciences.

Brege, D.A., W.E. Farr, and R.C. Johnsen. 1990. An air-lift pump for sampling juvenile salmonids at John Day Dam. North American Journal of Fisheries Management 10:481-483.

Clarke, W.C., and J.E. Shelbourn. 1985. Growth and development of seawater adaptability by juvenile fall chinook salmon (Oncorhynchus tshawytscha) in relation to temperature. Aquaculture 45:21-31.

Conte, F.P., and H.H. Wagner. 1965. Development of osmotic and ionic regulation in juvenile steelhead trout Salmo gairdneri. Comparative Biochemistry and Physiology 14:603-620.

Evans, D.H. 1984. The roles of gill permeability and transport mechanisms in euryhalinity. Pages 239-283 in W.S. Hoar and D.J. Randall, editors. Fish Physiology Volume X, Gills, Part B:Ion and Water Transfer. Academic Press. Orlando, Florida.

Fish Passage Center. Fish Passage Center 1992 Annual Report. Annual Report (Project 87-127) to Bonneville Power Administration, Portland, Oregon.

Folmar, L.C., and W.W. Dickhoff. 1980. The parr-smolt transformation (smoltification) and seawater adaptation in salmonids: A review of selected literature. Aquaculture $21: 1-37$.

Giorgi, A.E., D.R. Miller, and B.P. Sanford. 1990. Migratory behavior and adult contribution of summer outmigrating subyearling chinook salmon in John Day Reservoir, 1981-1983. Final Report (Contract DE-A179-83BP39645) to Bonneville Power Administration, Portland, Oregon.

Hoar, W.S. 1988. The physiology of smolting salmonids. Pages 275-343 in W.S. Hoar and D.J. Randall, editors. Fish Physiology Volume XI, The Physiology of Developing Fish, Part B: Viviparity and Posthatching Juveniles. Academic Press. San Diego, California.

Jefferts, K.B., P.K. Bergman, and H.F. Fiscus. 1963. A codedwire identification system for macro-organisms. Nature (London) 198:460-462. 
Matthews, G.M., and D.L. Park, S. Achord, and T.E. Reuhle. 1986. Static seawater challenge test to measure relative stress levels in spring chinook salmon smolts. Transactions of the American Fisheries Society 115:236-244.

Maule, A.G., C.B. Schreck, C.S. Bradford, and B.A. Barton. 1988. Physiological effects of collecting and transporting emigrating juvenile chinook salmon past dams on the Columbia River. Transactions of the American Fisheries Society $117: 245-261$.

Mighell, J.L. 1969. Rapid cold-branding of salmon and trout with liquid nitrogen. Journal of the Fisheries Research Board of Canada $26: 2765-2769$.

Redding, J.M., C.B. Schreck, E.K. Birks, and R.D. Ewing. 1984 . Cortisol and its effects on plasma thyroid hormone and electrolyte concentrations in fresh water and during seawater acclimation in yearling coho salmon, Oncorhynchus kisutch. General and Comparative Endocrinology 56:146-155.

Schreck, C.B., H.W. Li, A.G. Maule, B.A. Barton, L. Sigismondi, and P.J. Prete. 1984. Columbia river salmonid outmigration: McNary Dam passage and enhanced smolt quality. Report (Contract No.: DE-A179-82BP34797, Project 82-16) to Bonneville Power Administration, Portland, Oregon.

Schrock, R.M., J.W. Beeman, D.W. Rondorf, and P.V. Haner. 1994. A microassay for gill sodium, potassium - activated ATPase in juvenile salmon. Transactions of the American Fisheries Society (In Press).

Skalski, J.R. 1989. Statistical evaluation of the smolt monitoring program at McNary and John Day dams. Report to Pacific Northwest Utilities Conference Committee, Portland, Oregon.

Wagner, P.G. 1993. 1992 McNary Dam smolt monitoring program annual report. Annual Report (Project 87-127) to Bonneville Power Administration, Portland, Oregon.

Wedemeyer, G.A., R.L. Saunders, and W.C. Clarke. 1980. Environmental factors affecting smoltification and early marine survival of anadromous salmonids. Marine Fisheries Review $42(6): 1-14$.

Young, G., B.T. Bjornsson, P. Prunet, R.J. Lin, and H.A. Bern. 1989. Smoltification and seawater adaptation in coho salmon (Oncorhynchus kistuch) : plasma prolactin, growth hormone, thyroid hormones, and cortisol. General and Comparative Endocrinology $74: 335-345$. 
Zaugg, W.S., E.F. Prentice, and F.W. Waknitz. 1985. Importance of river migration to the development of seawater tolerance in Columbia River anadromous salmonids. Aquaculture 51:3347. 


\section{LIST OF APPENDICES}

Appendix 1. Snake River average daily discharge at Anatone gage, Washington (1991-1993) .

Appendix 2. Snake River main stem and tributary discharge data (1992-1993).

Appendix 3. Snake River water temperatures at RK 347 and RK 265 (1991-1993).

Appendix 4. IFG4 data deck used to simulate water velocity and depth at cross section 4 of the RK 261 spawning site.

Appendix 5. Data used in emigration rate analysis in 1992 .

Appendix 6. Total number ofincidental fish caught by beach seine in McNary Reservoir and the Hanford Reach of the Columbia River, WA, 1992.

Appendix 7. Mean catch/seine haul (CPUE) of subyearling chinook salmon caught by beach seine during one week sampling intervals in McNary Reservoir and the Hanford Reach of the Columbia River, Washington and in the Snake River, Idaho, Oregon, and Washington, 1992 .

Appendix 8. Mean fork length (FL) and standard deviation (SD) of subyearling chinook salmon caught by beach seine during one week sampling intervals in McNary Reservoir and the Hanford Reach of the Columbia River, Washington and in the snake River, Idaho, Oregon, and Washington, 1992.

Appendix 9. Summary of the number of subyearling chinook salmon marked with coded wire tags and brands of considered not suitable for marking at McNary Dam during 1992. 
Appendix 1. -Snake River average daily discharge at Anatone gage, Washington (1991-1993).

DATE

$18-$ Aug

$19-$ Aug

$20-$ Aug

21-Aug

22-Aug

23-Aug

24-Aug

25-Aug

26-Aug

27-Aug

28-Aug

29-Aug

30-Aug

31-Aug

01-Sep

02-Sep

03-Sep

04-Sep

05-Sep

06-Sep

07-Sep

08-Sep

09-Sep

10-Sep

11-Sep

$12-$ Sep

13 -Sep

14 -Sep

15 - Sep

16 -Sep

$17-\mathrm{sep}$

18 - Sep

$19-$ Sep

20-Sep

21 - Sep

22-Sep

23-Sep

24-Sep

25-Sep

26-Sep

27-Sep

28-Sep

29-Sep

30-Sep

01-Oct

02-Oct

03 -Oct

04-Oct

05-Oct

AUG-91 TO JUN-92 AVG AUG-92 TO JUN-93 AVG

11700

11900

14000

12200

11400

11300

11400

11000

11300

11700

12000

12100

12600

13500

13000

12800

12700

12800

13800

13500

17400

17300

19600

22200

22400

22700

23100

23300

23200

23200

23100

23100

23200

16200

18300

16600

16600

17600

16800

15600

16800

15900

15000

14400

15600

14500

15100

15000

16100
9650

9690

9620

9490

9440

9630

9570

9640

9580

9510

9510

9440

9390

9330

9260

9260

9270

9220

9230

9310

9410

9490

9590

9750

9850

9490

9640

9980

10100

10500

10800

10500

10500

10300

10400

11000

10200

10100

10400

11000

11400

11600

11800

12200

13650

15100

14700

14200

14300 
Appendix 1. (Continued) .

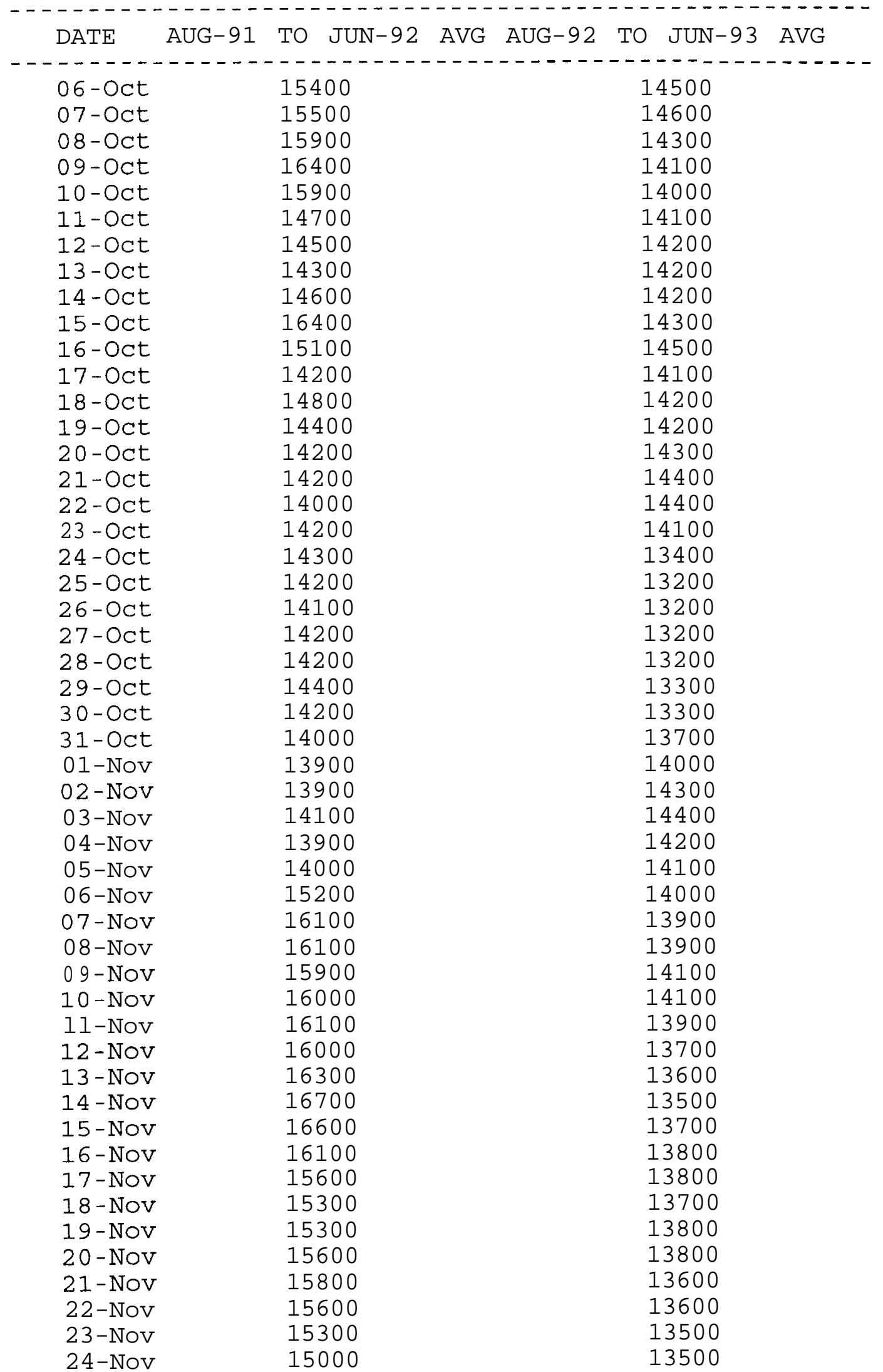


Appendix 1. (Continued) .

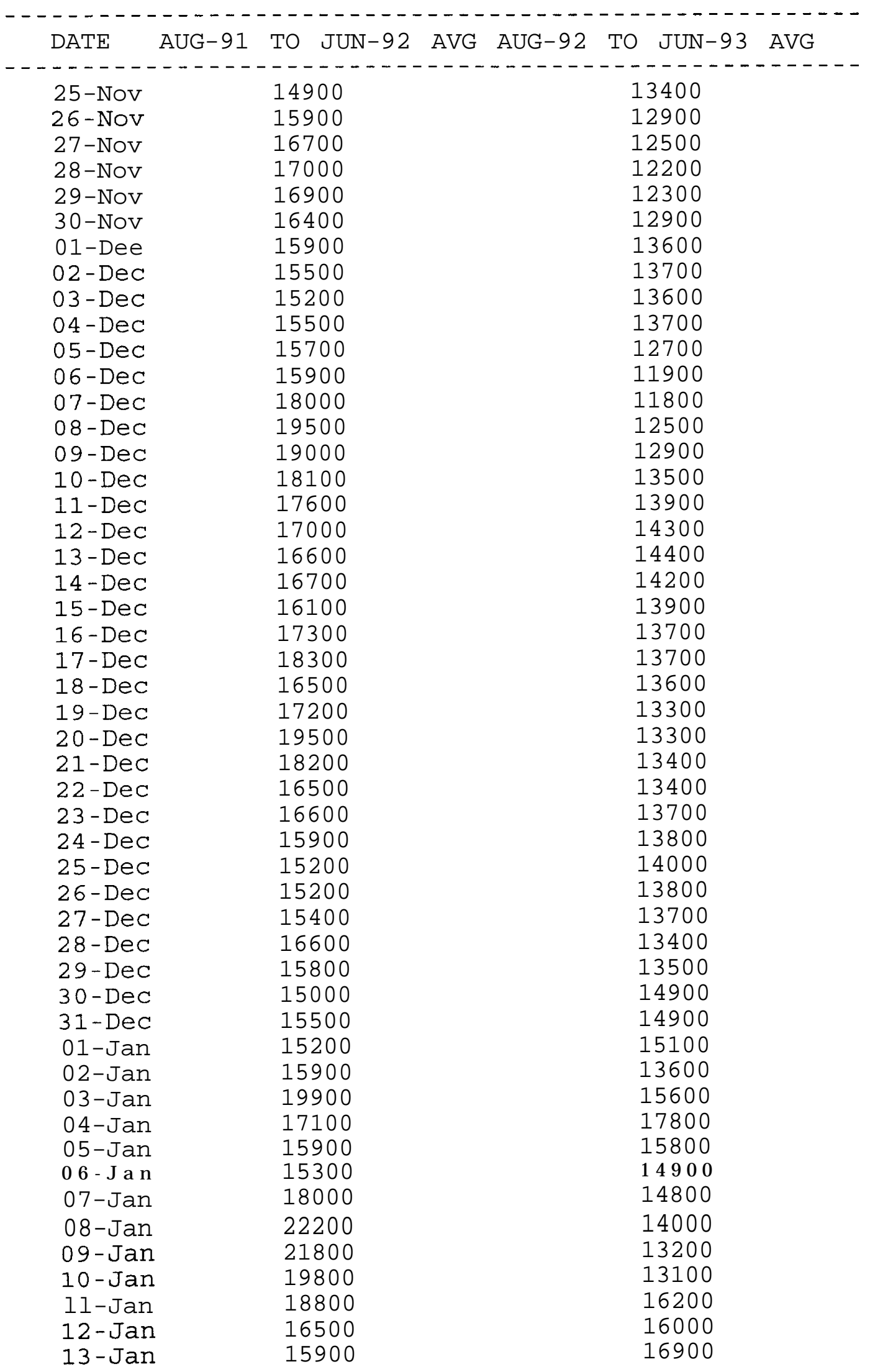


Appendix 1. (Continued) .

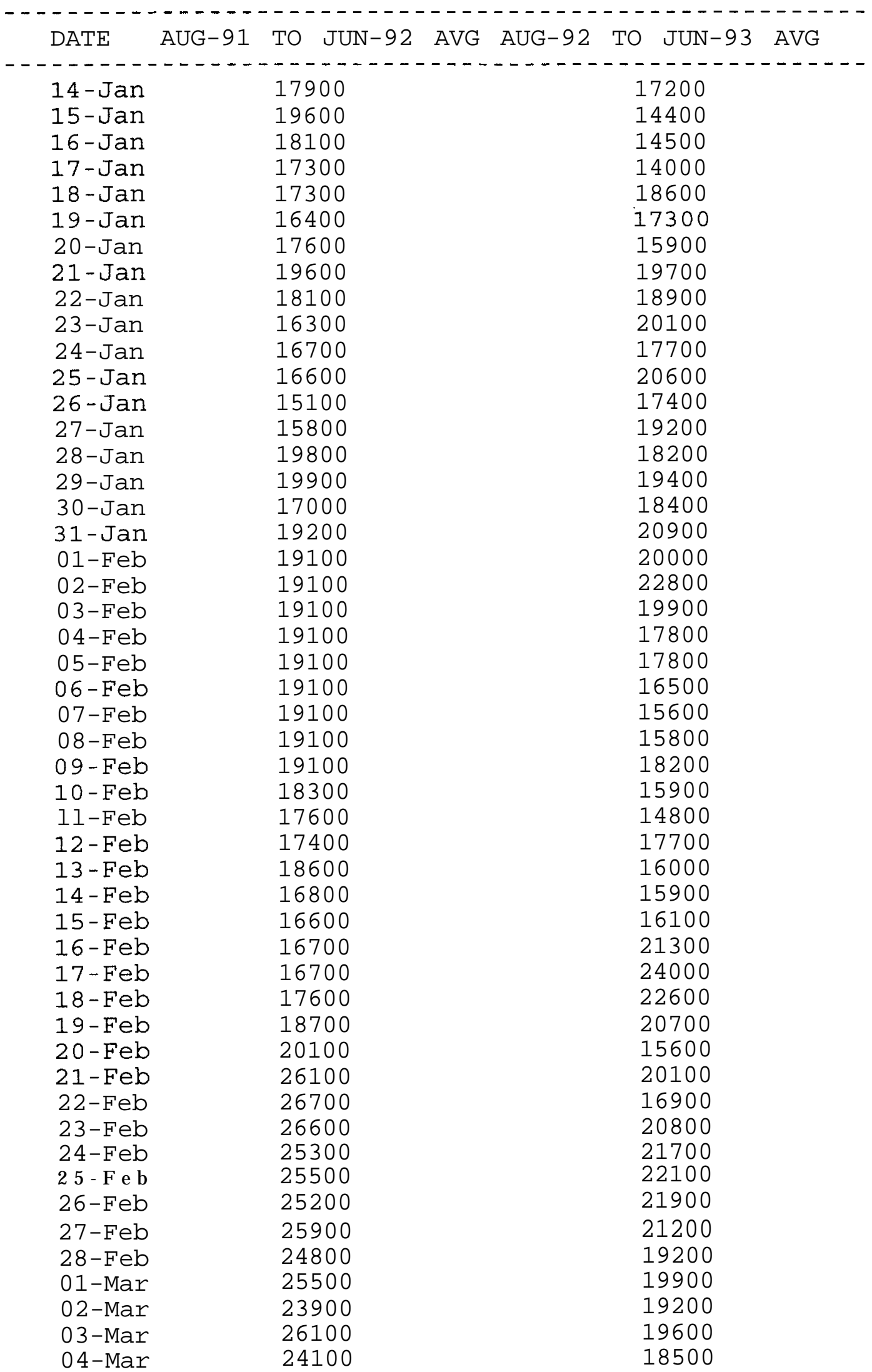


Appendix 1. (Continued) .

DATE AUG-91 TO JUN-92 AVG AUG-92 TO JUN-93 AVG

\begin{tabular}{|c|c|c|}
\hline 05-Mar & 24500 & 15600 \\
\hline 06-Mar & 25600 & 15400 \\
\hline 07-Mar & 23600 & 16500 \\
\hline 08-Mar & 23400 & 17800 \\
\hline 09-Mar & 23700 & 17500 \\
\hline 10-Mar & 23500 & 18300 \\
\hline 11-Mar & 24400 & 18400 \\
\hline $12-\operatorname{Mar}$ & 22600 & 20300 \\
\hline 13-Mar & 22900 & 23300 \\
\hline 14-Mar & 22000 & 22600 \\
\hline 15-Mar & 20100 & 21800 \\
\hline 16-Mar & 22200 & 20900 \\
\hline 17-Mar & 25300 & 21200 \\
\hline $18-\operatorname{Mar}$ & 23800 & 25900 \\
\hline 19-Mar & 24800 & 40500 \\
\hline 20-Mar & 20200 & 53400 \\
\hline 21-Mar & 19600 & 60200 \\
\hline 22-Mar & 19200 & 58100 \\
\hline 23-Mar & 20400 & 59000 \\
\hline 24-Mar & 22100 & 67400 \\
\hline 25-Mar & 18600 & 79700 \\
\hline 26-Mar & 18400 & 78300 \\
\hline 27-Mar & 18500 & 75200 \\
\hline 28-Mar & 18600 & 72900 \\
\hline 29-Mar & 18700 & 54400 \\
\hline 30-Mar & 18700 & 57700 \\
\hline 31-Mar & 18700 & 56000 \\
\hline $01-A p r$ & 18800 & 50800 \\
\hline 02-Apr & 19300 & 50600 \\
\hline 03-Apr & 20100 & 54900 \\
\hline 04-Apr & 21200 & 55100 \\
\hline 05-Apr & 22000 & 67600 \\
\hline $06-A p r$ & 21800 & 74700 \\
\hline 07-Apr & 21100 & 59500 \\
\hline 08-Apr & 20300 & 52000 \\
\hline 09-Apr & 19800 & 51500 \\
\hline 10-Apr & 20600 & 52400 \\
\hline 11-Apr & 22400 & 54400 \\
\hline $12-$ Apr & 23200 & 50800 \\
\hline 13-Apr & 24000 & 48000 \\
\hline $14-\mathrm{Apr}$ & 25500 & 46000 \\
\hline $15-\mathrm{Apr}$ & 25500 & 44100 \\
\hline 16-Apr & 25200 & 42300 \\
\hline 17-Apr & 25400 & 43100 \\
\hline 18 -Apr & 28000 & 43500 \\
\hline 19-Apr & 29100 & 48100 \\
\hline 20-Apr & 27800 & 42400 \\
\hline $21-\mathrm{Apr}$ & 26700 & 46800 \\
\hline 22-Apr & 27700 & 43000 \\
\hline 23-Apr & 28900 & 42500 \\
\hline
\end{tabular}


Appendix 1. (Continued) .

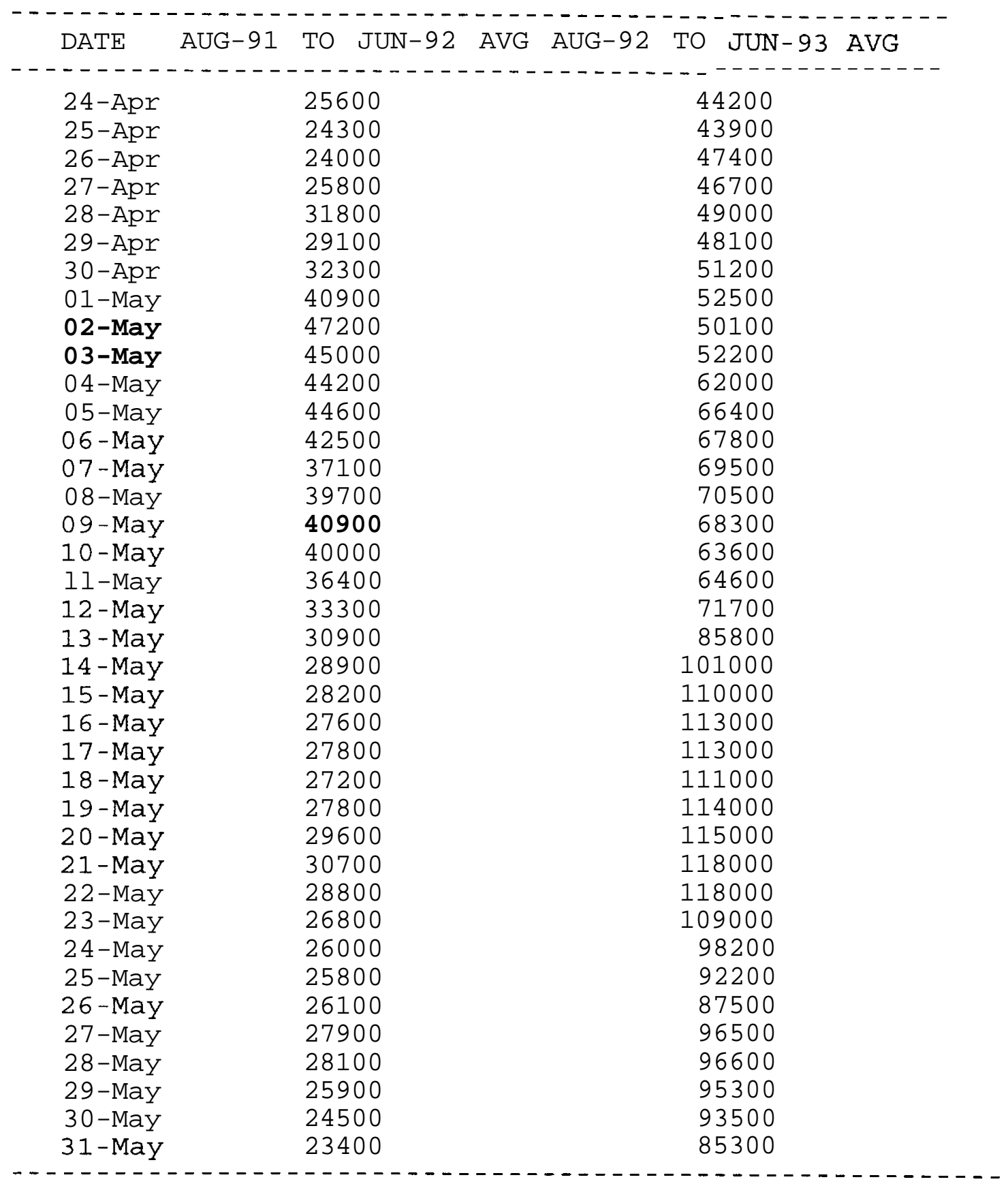


Appendix 2. -Snake River main stem and tributary discharge data (1992-1993) .

\begin{tabular}{|c|c|c|c|c|c|c|}
\hline MONTH & YEAR & $\begin{array}{c}\text { HELLS CANYON } \\
\text { DAM }\end{array}$ & $\begin{array}{l}\text { IMNAHA } \\
\text { RIVER }\end{array}$ & $\begin{array}{r}\text { SALMON } \\
\text { RIVER }\end{array}$ & $\begin{array}{c}\text { GRANDE } \quad \text { RONDE } \\
\text { RIVER }\end{array}$ & $\begin{array}{c}\text { SNAKE RIVER AT } \\
\text { (ANATONE, WA) }\end{array}$ \\
\hline 01-Aug & 1992 & 6580 & 138 & & & \\
\hline $02-$ Aug & 1992 & 6500 & $\begin{array}{l}130 \\
134\end{array}$ & $\begin{array}{l}3410 \\
3330\end{array}$ & $\begin{array}{l}569 \\
540\end{array}$ & 10600 \\
\hline 03 -Aug & 1992 & 6600 & 131 & 3240 & 505 & 10500 \\
\hline $04-A u g$ & 1992 & 6580 & 129 & 3120 & 473 & 10300 \\
\hline $05-A u g$ & 1992 & 6570 & 128 & 3020 & 444 & 10100 \\
\hline 06 -Aug & 1992 & 6600 & 126 & 3930 & 431 & 9990 \\
\hline 07-Aug & 1992 & 6610 & 126 & 3860 & 424 & 9910 \\
\hline 08-Aug & 1992 & 6640 & 126 & 3830 & 419 & 9870 \\
\hline 09-Aug & 1992 & 6680 & 124 & 3820 & 410 & 9880 \\
\hline 10-Aug & 1992 & 6720 & 118 & 2790 & 399 & 9900 \\
\hline 11-Aug & 1992 & 6790 & 115 & 2740 & 396 & 9980 \\
\hline 12 -Aug & 1992 & 6680 & 113 & 2690 & 395 & 9970 \\
\hline 13-Aug & 1992 & 6570 & 111 & 2630 & 384 & 9740 \\
\hline 14-Aug & 1992 & 6530 & 109 & 2560 & 375 & 9550 \\
\hline 15-Aug & 1992 & 6540 & 109 & 2520 & 374 & 9450 \\
\hline 16-Aug & 1992 & 6530 & 119 & 2530 & 368 & 9430 \\
\hline 17-Aug & 1992 & 6550 & 122 & 2620 & 384 & 9470 \\
\hline 18-Aug & 1992 & 6540 & 121 & 2720 & 398 & 9650 \\
\hline 19-Aug & 1992 & 6560 & 113 & 2720 & 403 & 9690 \\
\hline 20-Aug & 1992 & 6520 & 110 & 2650 & 391 & 9620 \\
\hline 21-Aug & 1992 & 6530 & 108 & 2570 & 393 & 9490 \\
\hline 22-Aug & 1992 & 6550 & 116 & 2510 & 747 & 9440 \\
\hline 23-Aug & 1992 & 6570 & 125 & 2580 & 526 & 9630 \\
\hline 24-Aug & 1992 & 6540 & 120 & 2610 & 527 & 9570 \\
\hline 25-Aug & 1992 & 6580 & 115 & 2640 & 498 & 9640 \\
\hline 26-Aug & 1992 & 6570 & 111 & 2620 & 489 & 9580 \\
\hline 27-Aug & 1992 & 6550 & 110 & 2600 & 468 & 9510 \\
\hline 28-Aug & 1992 & 6560 & 108 & 2610 & 451 & 9510 \\
\hline 29-Aug & 1992 & 6550 & 106 & 2560 & 436 & 9440 \\
\hline 30-Aug & 1992 & 6540 & 103 & 2510 & 425 & 9390 \\
\hline 31 -Aug & 1992 & 6530 & 101 & 2470 & 415 & 9330 \\
\hline 01-Sep & 1992 & 6520 & 100 & 2440 & 416 & 9260 \\
\hline $02-$ Sep & 1992 & 6560 & 99 & 2430 & 410 & 9260 \\
\hline
\end{tabular}


Appendix 2. (Continued).

\begin{tabular}{|c|c|c|c|c|c|c|}
\hline MONTH & YEAR & $\begin{array}{c}\text { HELLS CANYON } \\
\text { DAM }\end{array}$ & $\begin{array}{l}\text { IMNAHA } \\
\text { RIVER }\end{array}$ & $\begin{array}{r}\text { SALMON } \\
\text { RIVER }\end{array}$ & $\begin{array}{c}\text { GRANDE } \text { RONDE } \\
\text { RIVER }\end{array}$ & $\begin{array}{l}\text { SNAKE RIVER AT } \\
\text { (ANATONE, WA) }\end{array}$ \\
\hline 03-Sep & 1992 & 6530 & 98 & 2420 & 412 & 9270 \\
\hline 04 -Sep & 1992 & 6540 & 100 & 2400 & 417 & 9220 \\
\hline $05-$ sep & 1992 & 6540 & 104 & 2450 & 450 & 9230 \\
\hline $06-$ Sep & 1992 & 6530 & 105 & 2570 & 449 & 9310 \\
\hline 07-Sep & 1992 & 6520 & 105 & 2660 & 433 & 9410 \\
\hline $08-$ Sep & 1992 & 6560 & 105 & 2710 & 431 & 9490 \\
\hline $09-$ sep & 1992 & 6580 & 106 & 2750 & 448 & 9590 \\
\hline $10-$ sep & 1992 & 6870 & 104 & 2740 & 442 & 9750 \\
\hline $11-$ Sep & 1992 & 6540 & 102 & 2690 & 424 & 9850 \\
\hline $12-$ Sep & 1992 & 6610 & 103 & 2650 & 405 & 9490 \\
\hline $13-$ Sep & 1992 & 6900 & 103 & 2710 & 403 & 9640 \\
\hline $14-$ Sep & 1992 & 6900 & 103 & 2820 & 422 & 9980 \\
\hline $15-$ sep & 1992 & 7110 & 103 & 2740 & 459 & 10100 \\
\hline $16-$ Sep & 1992 & 7420 & 103 & 2670 & 478 & 10500 \\
\hline $17-$ Sep & 1992 & 7480 & 100 & 2650 & 465 & 10800 \\
\hline 18 -Sep & 1992 & 7410 & 99 & 2590 & 436 & 10500 \\
\hline $19-$ Sep & 1992 & 7400 & 98 & 2530 & 446 & 10500 \\
\hline $20-$ Sep & 1992 & 7290 & 97 & 2490 & 448 & 10300 \\
\hline $21-$ Sep & 1992 & 7740 & 97 & 2500 & 467 & 10400 \\
\hline 22-Sep & 1992 & 7430 & 96 & 2530 & 457 & 11000 \\
\hline 23-sep & 1992 & 7080 & 94 & 2520 & 446 & 10200 \\
\hline 24-Sep & 1992 & 7130 & 105 & 2530 & 505 & 10100 \\
\hline 25-Sep & 1992 & 7220 & 115 & 2820 & 806 & 10400 \\
\hline $26-$ Sep & 1992 & 7260 & 113 & 3320 & 747 & 11000 \\
\hline 27-Sep & 1992 & 7440 & 106 & 3380 & 658 & 11400 \\
\hline 28-Sep & 1992 & 7690 & 104 & 3220 & 637 & 11600 \\
\hline 29-Sep & 1992 & 7720 & 100 & 3140 & 620 & 11800 \\
\hline 30-Sep & 1992 & 10400 & 98 & 3000 & 600 & 12200 \\
\hline 01 -oct & 1992 & 11362 & 97 & 3051 & 577 & 13650 \\
\hline $02-$ oct & 1992 & 11604 & 97 & 2959 & 562 & 15100 \\
\hline 03 -oct & 1992 & 10595 & $102^{\circ}$ & 2938 & 574 & 14700 \\
\hline 04 -oct & 1992 & 10548 & 127 & 3093 & 642 & 14200 \\
\hline 05-Oct & 1992 & 10369 & 112 & 3345 & 650 & 14300 \\
\hline
\end{tabular}


Appendix 2. (Continued).

\begin{tabular}{|c|c|c|c|c|c|c|}
\hline MONTH & YEAR & $\begin{array}{c}\text { HELLS CANYON } \\
\text { DAM }\end{array}$ & $\begin{array}{l}\text { IMNAHA } \\
\text { RIVER }\end{array}$ & $\begin{array}{r}\text { SALMON } \\
\text { RIVER }\end{array}$ & $\begin{array}{c}\text { GRANDE } \\
\text { RIVNDE }\end{array}$ & $\begin{array}{c}\text { SNAKE RIVER AT } \\
\text { (ANATONE, }\end{array}$ \\
\hline----------1 & ---- & ----- & ---- & $\cdots-\cdots$ & ----- & ------------- \\
\hline 06-Oct & 1992 & 10343 & 106 & 3689 & 630 & 14500 \\
\hline $07-0 c t$ & 1992 & 10118 & 103 & 3593 & 620 & 14600 \\
\hline $08-0 c t$ & 1992 & 9893 & 102 & 3455 & 612 & 14300 \\
\hline 09-Oct & 1992 & 9761 & 103 & 3381 & 604 & 14100 \\
\hline $10-$ Oct & 1992 & 9782 & 102 & 3404 & 593 & 14000 \\
\hline $11-$ oct & 1992 & 10000 & 102 & 3393 & 593 & 14100 \\
\hline $12-$ oct & 1992 & 10179 & 101 & 3391 & 584 & 14200 \\
\hline 13 -oct & 1992 & 10178 & 102 & 3366 & 602 & 14200 \\
\hline $14-$ Oct & 1992 & 10201 & 104 & 3438 & 608 & 14200 \\
\hline 15-Oct & 1992 & 10312 & 103 & 3410 & 617 & 14300 \\
\hline $16-$ oct & 1992 & 10228 & 103 & 3340 & 608 & 14500 \\
\hline $17-$ oct & 1992 & 10162 & 106 & 3323 & 603 & 14100 \\
\hline 18 -oct & 1992 & 10204 & 107 & 3328 & 590 & 14200 \\
\hline $19-$ oct & 1992 & 10249 & 107 & 3310 & 581 & 14200 \\
\hline $20-$ oct & 1992 & 10407 & 105 & 3313 & 573 & 14300 \\
\hline $21-$ Oct & 1992 & 10438 & 106 & 3331 & 575 & 14400 \\
\hline $22-$ oct & 1992 & 10286 & 108 & 3316 & 588 & 14400 \\
\hline $23-$ oct & 1992 & 9865 & 108 & 3297 & 604 & 14100 \\
\hline $24-$ Oct & 1992 & 9114 & 106 & 3282 & 589 & 13400 \\
\hline $25-0 c t$ & 1992 & 9225 & 106 & 3257 & 573 & 13200 \\
\hline $26-0 c t$ & 1992 & 9203 & 106 & 3257 & 573 & 13200 \\
\hline $27-0 c t$ & 1992 & 9244 & 106 & 3234 & 574 & 13200 \\
\hline $28-0 c t$ & 1992 & 9283 & 107 & 3225 & 584 & 13200 \\
\hline $29-0 c t$ & 1992 & 9206 & 117 & 3264 & 605 & 13300 \\
\hline $30-0 c t$ & 1992 & 9199 & 155 & 3438 & 664 & 13300 \\
\hline $31-$ oct & 1992 & 9160 & 156 & 3765 & 745 & 13700 \\
\hline $01-$ Nov & 1992 & 9147 & 139 & 3384 & 858 & 14000 \\
\hline $02-\mathrm{Nov}$ & 1992 & 9102 & 153 & 4015 & 966 & 14300 \\
\hline $03-\mathrm{Nov}$ & 1992 & 9099 & 141 & 4058 & 929 & 14400 \\
\hline $04-$ Nov & 1992 & 9144 & 129 & 3967 & 850 & 14200 \\
\hline 05-Nov & 1992 & 9101 & 127 & 3836 & 884 & 14100 \\
\hline $06-$ Nov & 1992 & 9101 & 123 & 3724 & 857 & 14000 \\
\hline 07-Nov & 1992 & 9209 & 123 & 3666 & 864 & 13900 \\
\hline
\end{tabular}


Appendix 2. (Continued).

\begin{tabular}{|c|c|c|c|c|c|c|}
\hline MONTH & YEAR & $\begin{array}{c}\text { HELLS CANYON } \\
\text { DAM }\end{array}$ & $\begin{array}{l}\text { IMNAHA } \\
\text { RIVER }\end{array}$ & $\begin{array}{l}\text { SALMON } \\
\text { RIVER }\end{array}$ & $\begin{array}{c}\text { GRANDE } \\
\text { RIVNDE } \\
\text { RIVER }\end{array}$ & $\begin{array}{c}\text { SNAKE RIVER AT } \\
\text { (ANATONE, WA) }\end{array}$ \\
\hline$-\cdots---\cdots$ & $1 \cap 0$ & 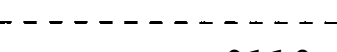 & $\cdots$ & 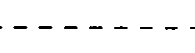 & ------- & $\cdots \cdots-\cdots$ \\
\hline $08-\mathrm{Nov}$ & 1992 & 9110 & 130 & 3725 & 959 & 13900 \\
\hline 09 -Nov & 1992 & 9137 & 128 & 3794 & 990 & 14100 \\
\hline $10-$ Nov & 1992 & 9081 & 119 & 3793 & 925 & 14100 \\
\hline 11 -Nov & 1992 & 9080 & 105 & 3660 & 868 & 13900 \\
\hline $12-$ Nov & 1992 & 9128 & 123 & 3447 & 836 & 13700 \\
\hline 13 -Nov & 1992 & 9107 & 122 & 3363 & 833 & 13600 \\
\hline $14-$ Nov & 1992 & 9079 & 118 & 3561 & 818 & 13500 \\
\hline $15-$ Nov & 1992 & 9109 & 118 & 3646 & 821 & 13700 \\
\hline $16-$ Nov & 1992 & 9075 & 119 & 3632 & 817 & 13800 \\
\hline 17-Nov & 1992 & 9075 & 119 & 3596 & 798 & 13800 \\
\hline 18 -Nov & 1992 & 9109 & 120 & 3589 & 804 & 13700 \\
\hline $19-$ Nov & 1992 & 9112 & 118 & 3602 & 812 & 13800 \\
\hline 20 -Nov. & 1992 & 9092 & 119 & 3566 & 800 & 13800 \\
\hline 21 -Nov & 1992 & 9060 & 113 & 3442 & 807 & 13600 \\
\hline 22-Nov & 1992 & 9091 & 109 & 3414 & 833 & 13600 \\
\hline 23-Nov & 1992 & 9098 & 122 & 3409 & 816 & 13500 \\
\hline 24-Nov & 1992 & 9111 & 89 & 3496 & 776 & 13500 \\
\hline $25-\mathrm{Nov}$ & 1992 & 9090 & 46 & 3220 & 693 & 13400 \\
\hline 26-Nov & 1992 & 9101 & 58 & 3702 & 667 & 12900 \\
\hline $27-\mathrm{Nov}$ & 1992 & 9096 & 85 & 2236 & 669 & 12500 \\
\hline 28-Nov & 1992 & 9063 & 123 & 3090 & 751 & 12200 \\
\hline 29-Nov & 1992 & 9078 & 124 & 3736 & 731 & 12300 \\
\hline $30-\mathrm{Nov}$ & 1992 & 9164 & 107 & 3269 & 696 & 12900 \\
\hline 01-Dee & 1992 & 9334 & 103 & 3359 & 722 & 13600 \\
\hline $02-\mathrm{DeC}$ & 1992 & 9326 & 112 & 3254 & 711 & 13700 \\
\hline $03-$ Dec & 1992 & 9396 & 109 & 3334 & 679 & 13600 \\
\hline $04-\mathrm{DeC}$ & 1992 & 9249 & 59 & 3146 & 656 & 13700 \\
\hline 05-Dec & 1992 & 9177 & 44 & 2311 & 550 & 12700 \\
\hline $06-$ Dec & 1992 & 9179 & 28 & 2055 & 518 & 11900 \\
\hline 07 -Dec & 1992 & 9186 & 130 & 1964 & 828 & 11800 \\
\hline 08-Dec & 1992 & 9138 & 129 & 2379 & 1220 & 12500 \\
\hline 09-Dec & 1992 & 9146 & 114 & 3043 & 1050 & 12900 \\
\hline $10-$ Dec & 1992 & 9170 & 114 & 3354 & 10.10 & 13500 \\
\hline
\end{tabular}


Appendix 2. (Continued).

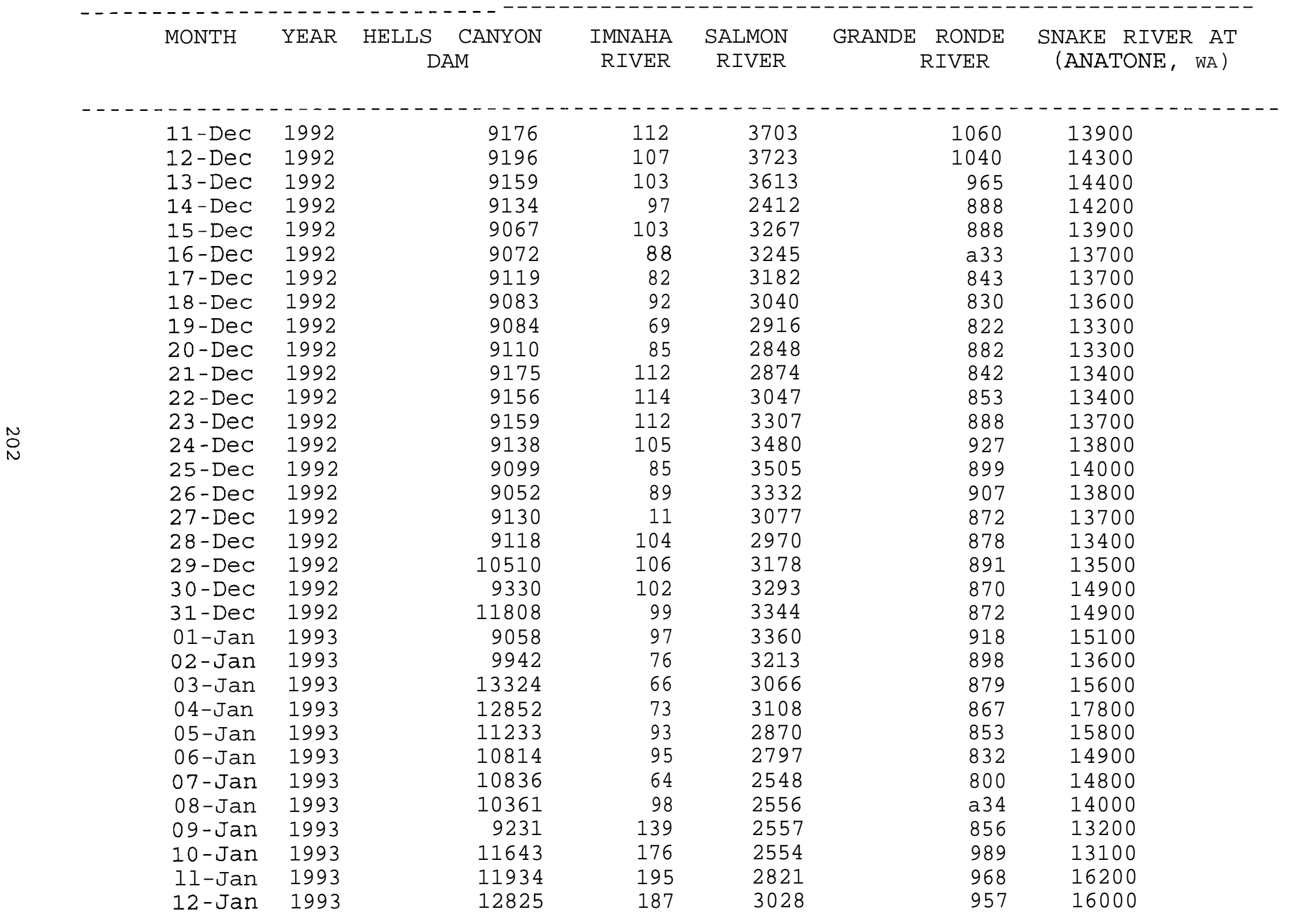


Appendix 2. (Continued).

\begin{tabular}{|c|c|c|c|c|c|c|}
\hline MONTH & YEAR & $\begin{array}{c}\text { HELLS CANYON } \\
\text { DAM }\end{array}$ & $\begin{array}{l}\text { IMNAHA } \\
\text { RIVER }\end{array}$ & $\begin{array}{r}\text { SALMON } \\
\text { RIVER }\end{array}$ & $\begin{array}{c}\text { GRANDE } \quad \text { RONDE } \\
\text { RIVER }\end{array}$ & $\begin{array}{c}\text { SNAKE RIVER AT } \\
\text { (ANATONE, WA) }\end{array}$ \\
\hline & & & & & -- & ---- \\
\hline 13-Jan & 1993 & 13680 & 195 & 2897 & 977 & 16900 \\
\hline $14-J a n$ & 1993 & 10468 & 526 & 3044 & 1010 & 17200 \\
\hline $15-J a n$ & 1993 & 9981 & 1560 & 3214 & 1070 & 14400 \\
\hline 16-Jan & 1993 & 8768 & 1240 & 3086 & 1070 & 14500 \\
\hline 17-Jan & 1993 & 11126 & 709 & 3174 & 953 & 14000 \\
\hline $18-J a n$ & 1993 & 13571 & 378 & 3204 & 958 & 18600 \\
\hline 19-Jan & 1993 & 10677 & 336 & 3175 & 916 & 17300 \\
\hline 20-Jan & 1993 & 14579 & 163 & 3178 & 987 & 15900 \\
\hline 21 -Jan & 1993 & 13877 & 140 & 3093 & 1150 & 19700 \\
\hline 22-Jan & 1993 & 15237 & 140 & 3348 & 1220 & 18900 \\
\hline 23-Jan & 1993 & 14741 & 119 & 3383 & 1080 & 20100 \\
\hline 24-Jan & 1993 & 14551 & 118 & 3388 & 1050 & 17700 \\
\hline 25-Jan & 1993 & 13627 & 144 & 3344 & 976 & 20600 \\
\hline 26-Jan & 1993 & 14428 & 136 & 3203 & 933 & 17400 \\
\hline 27-Jan & 1993 & 14867 & 127 & 3189 & 930 & 19200 \\
\hline $28-J a n$ & 1993 & 13962 & 121 & 3192 & 934 & 18200 \\
\hline 29-Jan & 1993 & 14915 & 129 & 3131 & 938 & 19400 \\
\hline 30-Jan & 1993 & 15090 & 124 & 3165 & 919 & la400 \\
\hline 31 -Jan & 1993 & 16944 & 106 & 3166 & 942 & 20900 \\
\hline $01-$ Feb & 1993 & 18646 & 115 & 3008 & 925 & 20000 \\
\hline $02-$ Feb & 1993 & 15857 & 116 & 2802 & 890 & 22800 \\
\hline 03-Feb & 1993 & 15395 & 123 & 2733 & 916 & 19900 \\
\hline $04-\mathrm{Feb}$ & 1993 & 13168 & 142 & 2813 & 931 & 17800 \\
\hline $05-$ Feb & 1993 & 14814 & 136 & 2832 & 954 & 17800 \\
\hline $06-$ Eeb & 1993 & 11909 & 141 & 2899 & 959 & 16500 \\
\hline 07-Feb & 1993 & 9269 & 146 & 2950 & 938 & 15600 \\
\hline $08-$ Feb & 1993 & 14950 & 142 & 2986 & 950 & 15800 \\
\hline 09-Feb & 1993 & 12304 & 149 & 3186 & 975 & 18200 \\
\hline $10-\mathrm{Feb}$ & 1993 & 9463 & 155 & 3279 & 1030 & 15900 \\
\hline $11-$ Feb & 1993 & 11681 & 156 & 3498 & 1140 & 14800 \\
\hline 12 - Feb & 1993 & 11043 & 155 & 3503 & 1230 & 17700 \\
\hline $13-\mathrm{Feb}$ & 1993 & 10737 & 153 & 3547 & 1280 & 16000 \\
\hline $14-$ Feb & 1993 & 9188 & 151 & 3561 & 1300 & 15900 \\
\hline
\end{tabular}


Appendix 2. (Continued).

\begin{tabular}{|c|c|c|c|c|c|c|}
\hline MONTH & YEAR & $\begin{array}{c}\text { HELLS CANYON } \\
\text { DAM }\end{array}$ & $\begin{array}{r}\text { IMNAHA } \\
\text { RIVER }\end{array}$ & $\begin{array}{l}\text { SALMON } \\
\text { RIVER }\end{array}$ & $\begin{array}{c}\text { GRANDE } \text { RONDE } \\
\text { RIVER }\end{array}$ & $\begin{array}{l}\text { SNAKE RIVER AT } \\
\text { (ANATONE, WA) }\end{array}$ \\
\hline & $\ldots$ & $\ldots$ & --- & 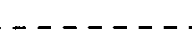 & 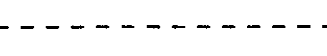 & $\ldots \ldots$ \\
\hline 15 -Feb & 1993 & 13816 & 150 & 3487 & 1320 & 16100 \\
\hline $16-$ Feb & 1993 & 18126 & 108 & 3192 & 1240 & 21300 \\
\hline $17-$ Feb & 1993 & 18212 & 80 & 2809 & 1150 & 24000 \\
\hline $18-F e b$ & 1993 & 18603 & 170 & 2618 & 1150 & 22600 \\
\hline 19-Feb & 1993 & 12983 & 186 & 2661 & 1140 & 20700 \\
\hline 20-Feb & 1993 & 15268 & 178 & 2980 & 1150 & 15600 \\
\hline $21-$ Feb & 1993 & 9777 & 157 & 3261 & 1180 & 20100 \\
\hline $22-F e b$ & 1993 & 15060 & 150 & 3348 & 1120 & 16900 \\
\hline 23-Feb & 1993 & 16063 & 147 & 3191 & 1070 & 20800 \\
\hline $24-F e b$ & 1993 & 16351 & 150 & 3240 & 1060 & 21700 \\
\hline 25-Feb & 1993 & 17748 & 134 & 3210 & 974 & 22100 \\
\hline $26-F e b$ & 1993 & 19654 & 97 & 3118 & 912 & 21900 \\
\hline 27-Feb & 1993 & 14713 & 115 & 3086 & 889 & 21200 \\
\hline $28-F e b$ & 1993 & 14027 & 144 & 3027 & 928 & 19200 \\
\hline 01-Mar & 1993 & 15917 & 136 & 2905 & 921 & 19900 \\
\hline 02-Mar & 1993 & 16522 & 146 & 2887 & 919 & 19200 \\
\hline 03-Mar & 1993 & 12276 & 142 & 3085 & 927 & 19600 \\
\hline 04-Mar & 1993 & 14235 & 139 & 3188 & 938 & 18500 \\
\hline 05-Mar & 1993 & 11155 & 145 & 3331 & 969 & 15600 \\
\hline 06-Mar & 1993 & 10774 & 148 & 3408 & 1070 & 15400 \\
\hline 07-Mar & 1993 & 11504 & 162 & 3534 & 1300 & 16500 \\
\hline 08-Mar & 1993 & 12053 & 193 & 3814 & 1740 & 17800 \\
\hline 09-Mar & 1993 & 10985 & 209 & 4146 & 2160 & 17500 \\
\hline 10-Mar & 1993 & 11249 & 215 & 4406 & 2430 & la300 \\
\hline 11-Mar & 1993 & 11072 & 223 & 4475 & 2630 & 18400 \\
\hline 12-Mar & 1993 & 14747 & 217 & 4392 & 2530 & 20300 \\
\hline 13-Mar & 1993 & 17107 & 218 & 4177 & 2310 & 23300 \\
\hline 14-Mar & 1993 & 13733 & 209 & 4040 & 2260 & 22600 \\
\hline 15-Mar & 1993 & 12137 & 210 & 4099 & 3350 & 21800 \\
\hline $16-\operatorname{Mar}$ & 1993 & 10088 & 219 & 4302 & 5350 & 20900 \\
\hline 17-Mar & 1993 & 11798 & 226 & 4541 & 4910 & 21200 \\
\hline 18-Mar & 1993 & 17359 & 276 & 4741 & 7100 & 25900 \\
\hline 19-Mar & 1993 & 28323 & 372 & 5222 & 9660 & 40500 \\
\hline
\end{tabular}


Appendix 2. (Continued).

\begin{tabular}{|c|c|c|c|c|c|c|}
\hline MONTH & YEAR & $\begin{array}{c}\text { HELLS CANYON } \\
\text { DAM }\end{array}$ & $\begin{array}{l}\text { IMNAHA } \\
\text { RIVER }\end{array}$ & $\begin{array}{l}\text { SALMON } \\
\text { RIVER }\end{array}$ & $\begin{array}{c}\text { GRANDE } \\
\text { RONDE } \\
\text { RIVER }\end{array}$ & $\begin{array}{c}\text { SNAKE RIVER AT } \\
\text { (ANATONE, WA) }\end{array}$ \\
\hline 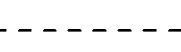 & $-\cdots$ & 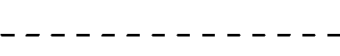 & 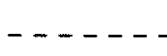 & 列 & ----- & $\ldots-\cdots$ \\
\hline 20-Mar & 1993 & 37124 & 485 & 6021 & 10200 & 53400 \\
\hline 21-Mar & 1993 & 38156 & 554 & 6746 & 10200 & 60200 \\
\hline 22-Mar & 1993 & 37030 & 525 & 6565 & 9290 & 58100 \\
\hline 23-Mar & 1993 & 37229 & 596 & 6400 & 10400 & 59000 \\
\hline 24-Mar & 1993 & 48647 & 1070 & 7081 & 13200 & 67400 \\
\hline 25-Mar & 1993 & 54801 & 1130 & 8313 & 11800 & 79700 \\
\hline 26-Mar & 1993 & 53571 & 976 & 8700 & 10200 & 78300 \\
\hline 27-Mar & 1993 & 51437 & 932 & 9292 & 9080 & 75200 \\
\hline 28-Mar & 1993 & 47479 & 939 & 9985 & 8610 & 72900 \\
\hline 29-Mar & 1993 & 38182 & 914 & 10033 & 8050 & 54400 \\
\hline 30-Mar & 1993 & 36395 & 796 & 9574 & 7220 & 57700 \\
\hline 31-Mar & 1993 & 34932 & 706 & 9024 & 6650 & 56000 \\
\hline $01-A p r$ & 1993 & 30027 & 761 & 8589 & 6800 & 50800 \\
\hline $02-A p r$ & 1993 & 32345 & a32 & 8798 & 7350 & 50600 \\
\hline 03-Apr & 1993 & 32183 & 845 & 8969 & 8370 & 54900 \\
\hline $04-\mathrm{Apr}$ & 1993 & 31798 & 1070 & 9387 & 11100 & 55100 \\
\hline 05-Apr & 1993 & 48516 & 918 & 10859 & 9830 & 67600 \\
\hline $06-\mathrm{Apr}$ & 1993 & 46232 & 810 & 10696 & 8480 & 74700 \\
\hline $07-A p r$ & 1993 & 34263 & 785 & 9796 & 7830 & 59500 \\
\hline 08-Apr & 1993 & 30419 & 791 & 8981 & 7610 & 52000 \\
\hline 09-Apr & 1993 & 30457 & 791 & 8836 & 8170 & 51500 \\
\hline 10-Apr & 1993 & 32530 & 791 & 9201 & 8120 & 52400 \\
\hline $11-\mathrm{Apr}$ & 1993 & 31016 & 791 & 9071 & 8030 & 54400 \\
\hline 12 -Apr & 1993 & 32252 & 791 & 8587 & 7340 & 50800 \\
\hline $13-$ Apr & 1993 & 31810 & 791 & 7980 & 6800 & 48000 \\
\hline $14-$ Apr & 1993 & 27646 & 791 & 7556 & 6480 & 46000 \\
\hline $15-\mathrm{Apr}$ & 1993 & 24994 & 791 & 7312 & 6180 & 44100 \\
\hline 16-Apr & 1993 & 27317 & 791 & 7204 & 5950 & 42300 \\
\hline $17-$ Apr & 1993 & 24670 & 791 & 7199 & 6010 & 43100 \\
\hline 18-Apr & 1993 & 27693 & 791 & 7728 & 6530 & 43500 \\
\hline 19-Apr & 1993 & 26637 & 796 & a325 & 6330 & 48100 \\
\hline 20-Apr & 1993 & 25976 & 821 & 8080 & 6010 & 42400 \\
\hline 21-Apr & 1993 & 28301 & 821 & 7835 & 5820 & 46800 \\
\hline
\end{tabular}


Appendix 2 .

(Continued).

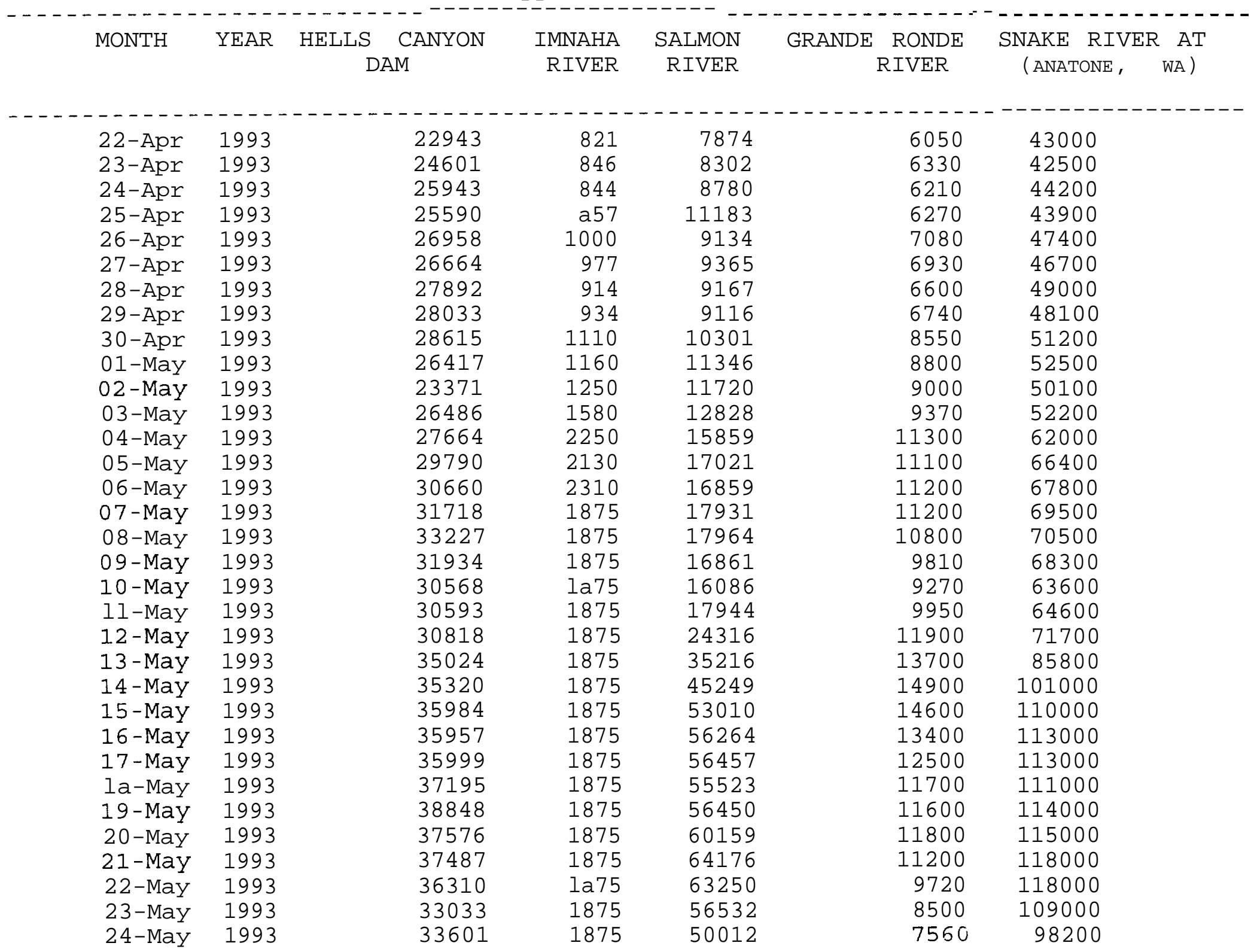


Appendix 2. (Continued).

$\begin{array}{lrrrrr}\text { MONTH } & \text { YEAR } & \begin{array}{c}\text { HELLS CANYON } \\ \text { DAM }\end{array} & \begin{array}{r}\text { IMNAHA } \\ \text { RIVER }\end{array} & \begin{array}{r}\text { SALMON } \\ \text { RIVER }\end{array} & \text { GRANDE RONDE SNAKE RIVER AT } \\ \text { RIVER } & \\ \text { (ANATONE, } & \\ \text { WA) }\end{array}$


Appendix 3. -Snake River water temperatures at RK 347 and RK 265 (1991-1993).

\begin{tabular}{|c|c|c|c|c|}
\hline MONTH & $\begin{array}{l}\text { RK } 265 \\
(1991-92)\end{array}$ & $\begin{array}{l}\text { RK } 265 \\
(1992-93)\end{array}$ & $\begin{array}{l}\text { RK } 347 \\
(1991-92)\end{array}$ & $\begin{array}{l}\text { RK } 347 \\
(1992-93)\end{array}$ \\
\hline 18-Aug & 22.6 & 22.5 & 20.6 & 21 \\
\hline 19-Aug & 22.9 & 22.5 & 20.8 & 21.1 \\
\hline 20-Aug & 22.8 & 22.5 & 20.7 & 21.1 \\
\hline 21-Aug & 22.6 & 22.2 & 20.8 & 20.8 \\
\hline 22-Aug & 22.7 & 21.2 & 20.7 & 20.3 \\
\hline 23-Aug & 22.7 & 20 & 20.7 & 19.9 \\
\hline 24-Aug & 22.1 & 19.4 & 20.6 & 19.9 \\
\hline 25-Aug & 21.8 & 19.3 & 20.6 & 20 \\
\hline 26-Aug & 21 & 19.5 & 20.5 & 20.3 \\
\hline 27-Aug & 20.8 & 19.9 & 20.7 & 20.5 \\
\hline 28-Aug & 20.8 & 20.3 & 20.6 & 20.8 \\
\hline 29-Aug & 20.9 & 20.2 & 21 & 20.3 \\
\hline 30-Aug & 21.3 & 20 & 21.2 & 19.9 \\
\hline 31 -Aug & 21.6 & 19.8 & 21.2 & 19.8 \\
\hline $01-$ sep & 21.4 & 20 & 20.8 & 20.1 \\
\hline 02 -Sep & 20.7 & 20.2 & 20.5 & 20.4 \\
\hline 03-Sep & 20.6 & 20.3 & 20.5 & 20.2 \\
\hline $04-$ Sep & 20.6 & 20 & 20.7 & 20 \\
\hline 05-Sep & 20.8 & 19.4 & 21 & 19.7 \\
\hline 06-Sep & 21.1 & 18.7 & 21.1 & 19.4 \\
\hline 07-Sep & 21.3 & 18.2 & 21.3 & 19.4 \\
\hline 08-Sep & 21.1 & 18.2 & 20.9 & 19.3 \\
\hline 09 -Sep & 20.5 & 18.4 & 20.8 & 19.7 \\
\hline $10-$ Sep & 20.6 & 18.6 & 21 & 19.7 \\
\hline $11-$ Sep & 20.6 & 19.2 & 21 & 19.9 \\
\hline $12-$ sep & 20.8 & 19 & 21 & 19.7 \\
\hline $13-$ Sep & 20.6 & 18.3 & 20.8 & 19.1 \\
\hline $14-$ Sep & 20 & 17.4 & 20.7 & 18.8 \\
\hline $15-$ sep & 20 & 17 & 20.5 & 18.7 \\
\hline 16 - Sep & 20 & 17.3 & 20.7 & 18.9 \\
\hline 17 - Sep & 20.1 & 17.7 & 20.8 & 19.2 \\
\hline $18-$ Sep & 20.2 & 17.7 & 20.8 & 18.7 \\
\hline 19-Sep & 20.2 & 17.7 & 20.8 & 1 a. 9 \\
\hline $20-$ Sep & 20 & 18 & 20.6 & 19 \\
\hline $21-$ Sep & 19.5 & 18.5 & 20.2 & 19.3 \\
\hline 22-Sep & 18.8 & 18.9 & 19.9 & 19.4 \\
\hline 23-Sep & 18.5 & 19.2 & 20 & 19.3 \\
\hline 24-Sep & 19 & 18.7 & 20 & 18.8 \\
\hline $25-$ sep & 19.1 & 17.9 & 20 & 18.6 \\
\hline 26-Sep & 19.3 & 17.4 & 20 & $1 a \cdot 6$ \\
\hline 27-sep & 19.6 & 17.4 & 20 & 18.8 \\
\hline 28-Sep & 19.3 & 17.4 & 19.9 & 18.7 \\
\hline 29-Sep & 19.2 & 17.6 & 19.9 & 18.8 \\
\hline 30-Sep & 19.1 & 17.8 & 19.9 & 18.9 \\
\hline 01 -oct & 19.1 & 18.3 & 19.8 & 18.9 \\
\hline $02-$ oct & $1 a \cdot 9$ & 18.2 & 19.7 & 18.8 \\
\hline $03-$ oct & 18.6 & 18.1 & 19.2 & 18.6 \\
\hline 04 -Oct & 17.5 & 17.8 & 18.9 & 18.6 \\
\hline
\end{tabular}


Appendix 3. (Continued) .

\begin{tabular}{|c|c|c|c|c|}
\hline MONTH & $\begin{array}{l}\text { RK } 265 \\
(1991-92)\end{array}$ & $\begin{array}{l}\text { RK } 265 \\
(1992-93)\end{array}$ & $\begin{array}{l}\text { RK } 347 \\
(1991-92)\end{array}$ & $\begin{array}{l}\text { RK } 347 \\
(1992-93)\end{array}$ \\
\hline \multirow{2}{*}{\multicolumn{5}{|c|}{ 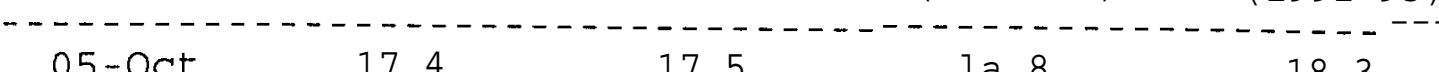 }} \\
\hline 05-oct & 17.4 & 17.5 & $1 \mathrm{a} .8$ & \\
\hline $06-0 c t$ & 17.2 & 17 & $1 \mathrm{a} .7$ & 18.2 \\
\hline $07-0 c t$ & 17.1 & 16.5 & 18.7 & 17.8 \\
\hline $08-$ Oct & 17.2 & 16.2 & 18.4 & 17.7 \\
\hline 09-oct & 17 & 16.1 & 18.2 & 17.8 \\
\hline $10-$ oct & 16.9 & 16.2 & 18.2 & 17.7 \\
\hline 11 -Oct & 16.7 & 16.2 & 18.1 & 17.7 \\
\hline $12-$ oct & 16.6 & 16.1 & 18 & 17.6 \\
\hline $13-$ Oct & 16.4 & 16 & 17.9 & 17.5 \\
\hline 14 -Oct & 16.2 & 15.6 & 17.8 & 17 \\
\hline $15-$ oct & 16.3 & 14.8 & 17.8 & 16.7 \\
\hline 16 -Oct & 16.4 & 14.4 & 17.7 & 16.5 \\
\hline 17 -Oct & 15.7 & 14.6 & 17.3 & 16.7 \\
\hline $18-\mathrm{Oct}$ & 15 & 14.8 & 17 & 16.6 \\
\hline 19 -oct & 15 & 15 & 17 & 16.6 \\
\hline $20-$ oct & 15 & 15.1 & 16.9 & 16.4 \\
\hline $21-$ Oct & 14.9 & 14.8 & 16.8 & 16.3 \\
\hline $22-$ Oct & 14.7 & 14.8 & 16.4 & 16.2 \\
\hline $23-$ oct & 14.2 & 14.7 & 16.2 & 16 \\
\hline 24 -oct & 13.8 & 14.3 & 15.8 & 15.8 \\
\hline $25-$ Oct & 13.5 & 14 & 15.7 & 15.7 \\
\hline $26-$ oct & 13.2 & 13.9 & 15.5 & 15.6 \\
\hline 27 -Oct & 12.9 & 13.7 & 15.3 & 15.5 \\
\hline $28-$ oct & 12.4 & 13.4 & 14.9 & 15.3 \\
\hline 29-oct & 11.8 & 13.3 & 14.5 & 15.3 \\
\hline $30-$ Oct & 11.2 & 13.2 & 14.1 & 15 \\
\hline $31-$ Oct & 11 & 13 & 14 & 14.9 \\
\hline $01-$ Nov & 11 & 12.9 & 13.9 & 14.8 \\
\hline $02-\mathrm{Nov}$ & 10.6 & 12.5 & 13.3 & 14.5 \\
\hline 03-Nov & 9.9 & 12.2 & 13.1 & 14.3 \\
\hline $04-\mathrm{Nov}$ & 10 & 11.7 & 12.8 & 13.9 \\
\hline $05-\mathrm{Nov}$ & 10.2 & 11.7 & 12.8 & 13.9 \\
\hline $06-$ Nov & 10.1 & 11.5 & 12.7 & 13.7 \\
\hline $07-$ Nov & 9.8 & 11.5 & 12.6 & 13.5 \\
\hline 08-Nov & 9.4 & 11.4 & 12.6 & 13.4 \\
\hline O9-NOV & 9.7 & 11.1 & 12.5 & 13.1 \\
\hline $10-\mathrm{Nov}$ & 10 & 10.6 & 12.2 & 12.8 \\
\hline $11-\mathrm{Nov}$ & 9.8 & 10.3 & 12.1 & 12.4 \\
\hline $12-\mathrm{Nov}$ & 9.9 & 10.2 & 12.1 & 12.5 \\
\hline $13-\mathrm{Nov}$ & 10.1 & 10.3 & 12 & 12.5 \\
\hline $14-$ Nov & 9.8 & 10.3 & 11.7 & 12.3 \\
\hline $15-\mathrm{Nov}$ & 9.3 & 10.1 & 11.4 & 12.1 \\
\hline $16-$ Nov & 8.9 & 9.9 & 11.2 & 12 \\
\hline 17 -Nov & 9 & 9.9 & 11.2 & 11.9 \\
\hline 18 -Nov & 9.1 & 9.9 & 11.1 & 11.8 \\
\hline $19-$ Nov & 9.1 & 9.6 & 10.8 & 11.4 \\
\hline $20-\mathrm{Nov}$ & 9 & 9.2 & 10.7 & 11.3 \\
\hline $21-\mathrm{NOV}$ & 8.6 & 8.9 & 10.4 & 11 \\
\hline $22-\mathrm{Nov}$ & 8.3 & 8.7 & 10 & 11 \\
\hline
\end{tabular}


Appendix 3. (Continued).

\begin{tabular}{|c|c|c|c|c|}
\hline MONTH & $\begin{array}{l}\text { RK } 265 \\
(1991-92)\end{array}$ & $\begin{array}{l}\text { RK } 265 \\
(1992-93)\end{array}$ & $\begin{array}{l}\text { RK } 347 \\
(1991-92)\end{array}$ & $\begin{array}{l}\text { RK } 347 \\
(1992-93)\end{array}$ \\
\hline$---\cdots---$ & $-------\cdots$ & $---\cdots-\cdots$ & $-\cdots---\cdots$ & $-\cdots----\cdots$ \\
\hline 23-Nov & 7.7 & 8.5 & 9.7 & 10.9 \\
\hline 24-Nov & 7.6 & 8.2 & 9.7 & 10.4 \\
\hline 25-Nov & 7.7 & 7.5 & 9.6 & 10.1 \\
\hline 26-Nov & 7.5 & 7.2 & 9.5 & 9.8 \\
\hline $27-\mathrm{Nov}$ & 7.5 & 7.1 & 9.3 & 9.5 \\
\hline $28-\mathrm{Nov}$ & 7.1 & 7.2 & 9 & 9.6 \\
\hline 29-Nov & 6.7 & 7.2 & 8.8 & 9.3 \\
\hline $30-\mathrm{Nov}$ & 6.3 & 7.1 & a. 5 & 8.7 \\
\hline $01-$ Dee & 6.2 & 6.4 & 8.4 & 8.6 \\
\hline 02 -DeC & 6.4 & 6.2 & 8.3 & 8.5 \\
\hline 03 -DeC & 6.6 & 6 & 8.4 & 8 \\
\hline $04-\mathrm{Dec}$ & 6.8 & 5.5 & 8.3 & 7.7 \\
\hline $05-\mathrm{Dec}$ & 6.7 & 5 & 8.1 & 7.3 \\
\hline 06 -Dec & 6.8 & 4.9 & 8.1 & 6.9 \\
\hline $07-$ Dec & 6.5 & 4.9 & 7.9 & 7 \\
\hline $08-\mathrm{DeC}$ & 6.4 & 5 & 7.6 & 7.1 \\
\hline $09-\mathrm{DeC}$ & 6 & 5.2 & 7.5 & 7.2 \\
\hline $10-\mathrm{DeC}$ & 5.7 & 5.3 & 7.6 & 7.2 \\
\hline $11-$ Dec & 5.7 & 5.1 & 7.3 & 7 \\
\hline $12-\mathrm{Dec}$ & 6 & 4.9 & 7.3 & 6.8 \\
\hline 13 -Dec & 5.6 & 4.9 & 7.1 & 6.5 \\
\hline $14-\mathrm{DeC}$ & 5.3 & 4.9 & 6.8 & 6.4 \\
\hline 15-Dec & 4.8 & 4.9 & 6.7 & 6.4 \\
\hline $16-$ Dec & 4.6 & 4.6 & 6.7 & 6.3 \\
\hline 17-Dec & 5 & 4.6 & 6.6 & 6.2 \\
\hline $18-\mathrm{Dec}$ & 4.9 & 4.3 & 6.5 & 6.2 \\
\hline $19-\mathrm{DeC}$ & 5.2 & 4.1 & 6.5 & 5.8 \\
\hline 20-Dec & 5 & 4.1 & 6.3 & 5.7 \\
\hline $21-\mathrm{DeC}$ & 4.9 & 4.3 & 6 & 6 \\
\hline $22-\mathrm{DeC}$ & 4.8 & 4.6 & 6.2 & 6 \\
\hline 23 -Dec & 4.6 & 4.9 & 6 & 6 \\
\hline $24-\mathrm{Dec}$ & 4.7 & 4.9 & 5.9 & 5.9 \\
\hline 25-DeC & 4.4 & 4.5 & 5.9 & 5.5 \\
\hline $26-\mathrm{Dec}$ & 4.2 & 4.3 & 5.9 & 5.3 \\
\hline 27-Dec & 4.3 & 4.2 & 5.9 & 5.5 \\
\hline 28-Dec & 4.5 & 4.4 & 5.7 & 5.3 \\
\hline 29-Dec & 4.5 & 4.5 & 5.7 & 5.3 \\
\hline $30-\mathrm{Dec}$ & 4.5 & 4.4 & 5.7 & 5.1 \\
\hline 31 -Dec & 4.7 & 4.2 & 5.6 & 5 \\
\hline $01-J a n$ & 4.5 & 3.9 & 5.5 & 4.8 \\
\hline $02-J a n$ & 4.4 & 3.3 & 5.5 & 4.5 \\
\hline 03-Jan & 4.5 & 3.1 & 5.5 & 4.5 \\
\hline $04-J a n$ & 4.5 & 3.5 & 5.6 & 4.6 \\
\hline 05-Jan & 4.5 & 3.3 & 5.6 & 4.6 \\
\hline 06-Jan & 4.6 & 3.3 & 5.6 & 4.6 \\
\hline 07-Jan & 4.7 & 3.3 & 5.5 & 4.3 \\
\hline 08-Jan & 4.7 & 3.1 & 5.3 & 3.9 \\
\hline 09-Jan & 4.4 & 2.6 & 5.2 & 3.7 \\
\hline $10-J a n$ & 4.2 & 2.4 & 5.1 & 3.7 \\
\hline
\end{tabular}


Appendix 3. (Continued) .

\begin{tabular}{|c|c|c|c|c|}
\hline MONTH & $\begin{array}{l}\text { RK } 265 \\
(1991-92)\end{array}$ & $\begin{array}{l}\text { RK } 265 \\
(1992-93)\end{array}$ & $\begin{array}{l}\text { RK } 347 \\
(1991-92)\end{array}$ & $\begin{array}{l}\text { RK } 347 \\
(1992-93)\end{array}$ \\
\hline \multirow{2}{*}{\multicolumn{5}{|c|}{ 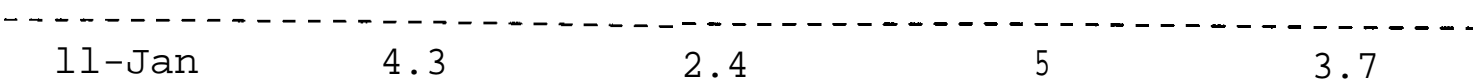 }} \\
\hline & & & 5 & \\
\hline 12-Jan & 4.3 & 2.5 & 4.9 & 3.6 \\
\hline $13-J a n$ & 4.4 & 2.4 & 4.8 & 3.5 \\
\hline $14-J a n$ & 4.3 & 2.8 & 4.7 & 3.5 \\
\hline 15-Jan & 4.2 & 2.7 & 4.6 & 3.6 \\
\hline 16-Jan & 4.3 & 2.8 & 4.7 & 3.4 \\
\hline $17-J a n$ & 4.3 & 2.6 & 4.8 & 3.2 \\
\hline $18-J a n$ & 4.4 & 2.7 & 4.6 & 2.8 \\
\hline 19-Jan & 3.9 & 2.4 & 4.4 & 2.5 \\
\hline 20-Jan & 3.6 & 2.3 & 4.4 & 2.8 \\
\hline 21-Jan & 3.7 & 2.6 & 4.3 & 2.8 \\
\hline 22-Jan & 3.7 & 2.6 & 4.2 & 2.8 \\
\hline 23-Jan & 3.7 & 2.4 & 4.3 & 2.5 \\
\hline 24-Jan & 4.1 & 2.3 & 4.5 & 2.5 \\
\hline 25-Jan & 4.3 & 2.6 & 4.4 & 2.6 \\
\hline 26-Jan & 4.1 & 2.7 & 4.3 & 2.5 \\
\hline 27-Jan & 4 & 2.6 & 4.3 & 2.2 \\
\hline 28-Jan & 4.4 & 2.4 & 4.6 & 2.1 \\
\hline 29-Jan & 4.6 & 2.4 & 4.4 & 2.1 \\
\hline 30-Jan & 4.5 & 2.3 & 4.2 & 1.9 \\
\hline $31-J a n$ & 4.3 & 2.1 & 4.1 & 1.6 \\
\hline 01-Feb & 4.3 & 1.9 & 3.8 & 1.5 \\
\hline 02 -Feb & 4.4 & 1.8 & 3.8 & 1.7 \\
\hline 03-Feb & 4.2 & 1.8 & 3.6 & 1.8 \\
\hline $04-$ Feb & 3.7 & 1.9 & 3.4 & 1.9 \\
\hline 05-Feb & 3.3 & 2 & 3.5 & 1.8 \\
\hline $06-$ Feb & 3.1 & 2.1 & 3.6 & 1.9 \\
\hline 07-Feb & 3.2 & 2.3 & 3.7 & 2 \\
\hline 08-Feb & 3.7 & 2.3 & 3.9 & 1.9 \\
\hline $09-$ Feb & 4 & 2.4 & 3.9 & 2 \\
\hline $10-$ Feb & 4.1 & 2.7 & 3.7 & 2.2 \\
\hline 11-Feb & 4.1 & 2.9 & 3.8 & 2.2 \\
\hline 12 - Feb & 4.2 & 3 & 3.7 & 2.2 \\
\hline $13-\mathrm{Feb}$ & 4.4 & 3.1 & 3.8 & 2.2 \\
\hline $14-$ Feb & 4.6 & 3.2 & 3.7 & 2.3 \\
\hline 15-Feb & 4.5 & 2.9 & 3.7 & 2.2 \\
\hline 16 -Feb & 4.4 & 2.1 & 3.8 & 1.9 \\
\hline $17-$ Feb & 4.3 & 1.6 & 3.7 & 1.9 \\
\hline $18-$ Feb & 4.3 & 1.8 & 3.9 & 2.1 \\
\hline 19-Feb & 4.5 & 2 & 4.1 & 2.2 \\
\hline 20-Feb & 5 & 2.1 & 4.1 & 2.3 \\
\hline $21-$ Feb & 5.3 & 2.4 & 4 & 2.1 \\
\hline 22-Feb & 5.4 & 2.3 & 4.1 & 2.1 \\
\hline 23-Feb & 5.4 & 2.4 & 4.1 & 2.1 \\
\hline 24-Feb & 5.5 & 2.4 & 4.2 & 2.1 \\
\hline 25-Feb & 5.8 & 2.2 & 4.3 & 2.1 \\
\hline 26-Feb & 5.9 & 2.2 & 4.4 & 2.3 \\
\hline 27-Feb & 5.9 & 2.3 & 4.4 & 2.3 \\
\hline 28-Feb & 5.9 & 2.5 & 4.5 & 2.3 \\
\hline
\end{tabular}


Appendix 3. (Continued) .

\begin{tabular}{|c|c|c|c|c|}
\hline MONTH & $\begin{array}{l}\text { RK 265 } \\
(1991-92)\end{array}$ & $\begin{array}{l}\text { RK 265 } \\
(1992-93)\end{array}$ & $\begin{array}{l}\text { RK } 347 \\
(1991-92)\end{array}$ & $\begin{array}{l}\text { RK } 347 \\
(1992-93)\end{array}$ \\
\hline 01-Mar & 6 & 2.6 & 4.6 & 2.2 \\
\hline 02-Mar & 6.2 & 2.8 & 4.8 & 2.3 \\
\hline 03-Mar & 6.5 & 2.9 & 4.9 & 2.2 \\
\hline 04-Mar & 6.5 & 2.8 & 5 & 2.3 \\
\hline 05-Mar & 6.8 & 3.3 & 5.2 & 2.6 \\
\hline 06-Mar & 6.7 & 3.8 & 5.1 & 2.8 \\
\hline 07-Mar & 6.7 & 4.2 & 5.2 & 3 \\
\hline 08-Mar & 7 & 4.3 & 5.6 & 3 \\
\hline 09-Mar & 7.4 & 4.5 & 5.7 & 3.1 \\
\hline 10-Mar & 7.5 & 4.5 & 5.9 & 3.2 \\
\hline 11-Mar & 7.5 & 4.3 & 6.3 & 3.2 \\
\hline 12-Mar & 7.6 & 4 & 6.6 & 3.1 \\
\hline 13-Mar & 7.8 & 4.1 & 6.8 & 3.4 \\
\hline 14-Mar & 8.1 & 4.6 & 6.9 & 3.5 \\
\hline 15-Mar & 8.4 & 4.8 & 7.1 & 3.7 \\
\hline 16-Mar & 8.8 & 5 & 7.4 & 3.9 \\
\hline 17-Mar & 9 & 5.4 & 7.5 & 4 \\
\hline 18-Mar & 8.6 & 5.8 & 7.4 & 4.1 \\
\hline 19-Mar & a. 4 & 5.7 & 7.4 & 4.1 \\
\hline 20-Mar & 8.3 & 5.6 & 7.2 & 4.2 \\
\hline 21-Mar & 8.4 & 5.6 & 7.5 & 4.5 \\
\hline 22-Mar & 8.6 & 5.9 & 7.6 & 4.6 \\
\hline 23-Mar & 8.8 & 6.1 & 7.9 & 4.7 \\
\hline 24-Mar & 9 & 6 & 8.3 & 4.7 \\
\hline 25-Mar & 9.2 & 5.8 & a. 5 & 4.8 \\
\hline 26-Mar & 9.4 & 6.3 & 8.7 & 5.6 \\
\hline 27-Mar & 9.7 & 6.9 & 8.7 & 6.2 \\
\hline 28-Mar & 9.6 & 7.4 & 8.8 & 6.5 \\
\hline 29-Mar & 9.3 & 7.6 & 8.7 & 6.9 \\
\hline 30-Mar & 9.2 & 7.8 & 8.6 & 7.2 \\
\hline 31-Mar & 9.4 & 8.1 & a. 9 & 7.5 \\
\hline 01-Apr & 10.2 & 8.4 & 9.3 & 7.6 \\
\hline $02-\operatorname{Apr}$ & 10.8 & 8.6 & 9.5 & 7.9 \\
\hline 03-Apr & 11.2 & 8.8 & 9.7 & 8.2 \\
\hline $04-\mathrm{Apr}$ & 11.5 & 8.5 & 10.1 & a. 2 \\
\hline $05-\mathrm{Apr}$ & 11.5 & 8.3 & 10 & 8.3 \\
\hline $06-\mathrm{Apr}$ & 11 & 8.5 & 9.7 & 8.4 \\
\hline $07-\mathrm{Apr}$ & 10.5 & 9 & 9.5 & 8.6 \\
\hline $08-\mathrm{Apr}$ & 9.8 & 9.2 & 9.6 & 8.7 \\
\hline 09-Apr & 9.5 & 9.2 & 9.9 & 8.8 \\
\hline $10-\mathrm{Apr}$ & 9.5 & 8.9 & 10 & 9 \\
\hline $11-A p r$ & 9.7 & 8.9 & 10.2 & 9.1 \\
\hline 12-Apr & 9.6 & 9 & 10.2 & 9.2 \\
\hline 13-Apr & 9.8 & 9.1 & 10.3 & 9.4 \\
\hline $14-\mathrm{Apr}$ & 10.4 & 9.6 & 10.7 & 9.6 \\
\hline $15-\mathrm{Apr}$ & 11.1 & 9.6 & 10.8 & 9.4 \\
\hline $16-\mathrm{Apr}$ & 11.7 & 9.5 & 10.8 & 9.5 \\
\hline $17-\mathrm{Apr}$ & 11.8 & 10 & 10.9 & 9.6 \\
\hline $18-\mathrm{Apr}$ & 11.8 & 10.1 & 11 & 9.8 \\
\hline
\end{tabular}


Appendix 3. (Continued).

\begin{tabular}{|c|c|c|c|c|}
\hline MONTH & $\begin{array}{l}\text { RK } 265 \\
(1991-92)\end{array}$ & $\begin{array}{l}\text { RK } 265 \\
(1992-93)\end{array}$ & $\begin{array}{l}\text { RK } 347 \\
(1991-92)\end{array}$ & $\begin{array}{l}\text { RK } 347 \\
(1992-93)\end{array}$ \\
\hline \multicolumn{5}{|c|}{ 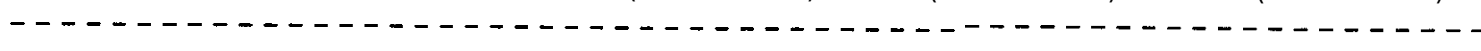 } \\
\hline 19-Apr & 11.4 & 10.2 & 10.8 & 10.1 \\
\hline $20-$ Apr & 11 & 10.3 & 10.8 & 10 \\
\hline $21-$ Apr & 11.3 & 10.4 & 11.2 & 10.1 \\
\hline $22-\mathrm{Apr}$ & 11.3 & 10.3 & 11.2 & 10.1 \\
\hline 23-Apr & 10.8 & 10.4 & 11 & 10.5 \\
\hline 24-Apr & 10.8 & 10.9 & 11 & 10.5 \\
\hline 25-Apr & 11 & 11 & 11.5 & 10.5 \\
\hline 26-Apr & 11.5 & 11.1 & 11.8 & 10.5 \\
\hline 27-Apr & 12.1 & 10.9 & 11.8 & 10.7 \\
\hline 28-Apr & 12.4 & 10.8 & 11.7 & 10.9 \\
\hline 29-Apr & 12. a & 11 & 11.8 & 11.1 \\
\hline 30-Apr & 13.3 & 11.1 & 12 & 11.3 \\
\hline 01-May & 13.3 & 11.1 & 11.9 & 11.3 \\
\hline 02-May & 12.5 & 11.4 & 11.7 & 11.4 \\
\hline 03-May & 12.2 & 11.2 & 12.1 & 11.4 \\
\hline 04-May & 12.6 & 10.6 & 12.6 & 11.4 \\
\hline 05-May & 12.9 & 10.6 & 12.6 & 11.7 \\
\hline $06-\mathrm{May}$ & 13.1 & 11.2 & 12. a & 11.6 \\
\hline 07-May & 13.6 & 10.8 & 13.2 & 11.6 \\
\hline 08-May & 14 & 10.9 & 13.5 & 11.7 \\
\hline 09-MaY & 13.8 & 11.3 & 13.4 & 11.9 \\
\hline 10-May & 12.9 & 12 & 13 & 12.2 \\
\hline 11-May & 12.6 & 12.7 & 13.3 & 12.6 \\
\hline $12-\mathrm{MaY}$ & 12.4 & 13.2 & 13.5 & 12.8 \\
\hline 13-May & 12.2 & 13.2 & 13.3 & 13.1 \\
\hline 14-May & 12.4 & 12.9 & 13.7 & 13.4 \\
\hline 15-May & 12.9 & 12.6 & 14.1 & 13.5 \\
\hline 16-May & 13.6 & 12.4 & 14.3 & 13.4 \\
\hline 17-May & 13.9 & 12.2 & 14.1 & 13.9 \\
\hline 18-May & 14.2 & 12.4 & 13.9 & 14.2 \\
\hline 19-May & 14.6 & 12.7 & 14.2 & 14.3 \\
\hline 20-May & 14.9 & 12.7 & 14.3 & 14.2 \\
\hline 21-May & 15.1 & 12.6 & 14 & 14.5 \\
\hline 22-May & 14.4 & 12.4 & 13.8 & 15 \\
\hline 23-May & 14.2 & 12.6 & 14.2 & 15.5 \\
\hline 24-May & 14.9 & 13 & 14.7 & 15.8 \\
\hline 25-May & 15.6 & 13.5 & 15 & 15.8 \\
\hline 26-May & 16.3 & 13.9 & 15.1 & 16 \\
\hline 27-May & 16.7 & 13.9 & 15 & 16 \\
\hline 28-May & 16.5 & 13.9 & 14.8 & 16 \\
\hline 29-May & 16.4 & 13.7 & 14.9 & 16.2 \\
\hline 30-May & 16.3 & 13.8 & 14.9 & 16.3 \\
\hline 31-May & 16.4 & 13.8 & 14.9 & 16.4 \\
\hline $01-J u n$ & 16.8 & 14 & 15 & 16.6 \\
\hline 02-Jun & 17.2 & 13.8 & 15.1 & 16.4 \\
\hline 03-Jun & 17.5 & 13.5 & 15.4 & 16.3 \\
\hline 04-Jun & 17.4 & 13.5 & 15 & 16.2 \\
\hline
\end{tabular}


Appendix 4.-IFG4 data deck used to simulate water velocity and depth at cross section four of the RK 261 spawning site.

SITE RK 261 TRANSECT 4 FLOW 3: 08/28/92 - CALIBRATED FOR 5400 TO $20000 \mathrm{CFS}$

RUN FOR 92 REPORT USING IFG4 W/ GAGE FLOW OF 9700 CFS SZF = 948.20

IOC $\quad 1100100001001000001000$

QARD 5400

QARD 5900

QARD 6400

QARD 6900

QARD 7400

QARD 7900

QARD 8400

QARD 8900

QARD 9400

QARD 9700

QARD 10400

QARD10900

QARD 11400

QARD1 1800

QARD 12400

QARD12900

QARD13400

QARD1 4000

QARD1 4300

QARD1 4900

QARD15400

QARD15700

QARD16200

QARD 16900

QARD17400

QARD 17900

QARD18400

QARD 18900

QARD19500

QARD19900

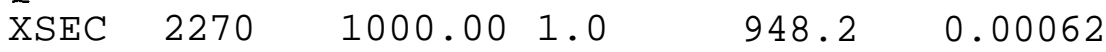

$\begin{array}{lll}2270 & 0.0970 .5 & 29.0961 .5 \quad 50.0958 .5\end{array}$

84.0957 .0122 .0954 .6132 .0953 .7

2270143.0954 .5164 .0957 .2192 .0957 .8234 .0956 .3281 .0954 .3304 .0953 .2

2270329.0952 .8344 .0952 .4358 .0951 .4386 .0950 .8416 .0949 .5453 .0948 .2

2270468.0946 .8487 .0944 .6503 .0942 .3511 .0940 .6526 .0940 .0538 .0938 .5

2270545.0938 .0561 .0938 .0569 .0937 .2578 .0935 .7583 .0936 .2596 .0936 .4

2270602.0937 .5618 .0940 .3629 .0945 .4637 .0947 .8645 .0950 .8668 .0950 .7 2270686.0952 .4697 .0953 .1715 .0954 .3735 .0957 .4748 .0962 .1
NS
2270
0.0
7.6
7.6
5.6
6.50 .08

6.5 


\begin{tabular}{|c|c|c|c|c|c|c|c|c|c|c|c|c|}
\hline $\begin{array}{l}\text { NS } \\
5.6\end{array}$ & \multicolumn{2}{|l|}{2270} & \multicolumn{2}{|l|}{6.5} & \multicolumn{2}{|l|}{6.5} & \multicolumn{2}{|l|}{5.6} & \multicolumn{2}{|c|}{5.60 .08} & \multicolumn{2}{|c|}{5.60 .08} \\
\hline $\begin{array}{l}\mathrm{NS} \\
0.0\end{array}$ & \multicolumn{2}{|c|}{22700.025} & \multicolumn{2}{|c|}{6.50 .025} & \multicolumn{2}{|l|}{6.5} & \multicolumn{2}{|l|}{6.5} & \multicolumn{2}{|l|}{6.6} & \multicolumn{2}{|l|}{6.6} \\
\hline $\begin{array}{l}\mathrm{NS} \\
0.0\end{array}$ & \multicolumn{2}{|l|}{2270} & \multicolumn{2}{|l|}{0.0} & \multicolumn{2}{|l|}{0.0} & \multicolumn{2}{|l|}{0.0} & \multicolumn{2}{|l|}{0.0} & \multicolumn{2}{|l|}{0.0} \\
\hline $\begin{array}{l}\mathrm{NS} \\
0.0\end{array}$ & \multicolumn{2}{|l|}{2270} & \multicolumn{2}{|l|}{0.0} & \multicolumn{2}{|l|}{0.0} & \multicolumn{2}{|l|}{0.0} & \multicolumn{2}{|c|}{0.00 .076} & \multicolumn{2}{|c|}{0.00 .076} \\
\hline $\begin{array}{l}\text { NS } \\
7.7\end{array}$ & \multicolumn{2}{|l|}{2270} & \multicolumn{2}{|c|}{0.00 .079} & \multicolumn{2}{|c|}{0.00 .075} & \multicolumn{2}{|l|}{0.0} & \multicolumn{2}{|c|}{0.00 .057} & \multicolumn{2}{|l|}{7.7} \\
\hline NS & 2270 & & \multirow{2}{*}{\multicolumn{4}{|c|}{$\begin{array}{rrr}7.70 .082 & 7.7 \\
54.31 & 9700.0\end{array}$}} & \multirow{2}{*}{\multicolumn{2}{|c|}{7.7}} & 7.7 & & 7.7 & \\
\hline CAL1 & 2270 & & & & & & & & & & & \\
\hline $\begin{array}{l}\text { VEL1 } \\
0.50\end{array}$ & 2270 & & & & & & 0001 & & & & & \\
\hline $\begin{array}{l}\text { VEL1 } \\
3.90\end{array}$ & 2270 & 2.20 & 3.10 & 3.00 & 3.35 & 3.30 & 3.40 & 3.25 & 3.45 & 3.55 & 3.55 & 3.80 \\
\hline $\begin{array}{l}\text { VEL1 } \\
1.55\end{array}$ & 2270 & 3.60 & 3.75 & 3.65 & 3.45 & 3.05 & 3.00 & 3.10 & 2.25 & 2.95 & 1.50 & 2.70 \\
\hline VEL1 & 2270 & 0.70 & 0.10 & & & & & & & & & \\
\hline CAL2 & 2270 & & 56.20 & 160 & 00.0 & & & & & & & \\
\hline VEL2 & 2270 & & & & & & & & & & & \\
\hline VEL2 & 2270 & & & & & & & & & & & \\
\hline VEL2 & 2270 & & & & & & & & & & & \\
\hline VEL2 & 2270 & & & & & & & & & & & \\
\hline CAL3 & 2270 & & 61.94 & 437 & 00.0 & & & & & & & \\
\hline VEL3 & 2270 & & & & & & & & & & & \\
\hline VEL3 & 2270 & & & & & & & & & & & \\
\hline VEL3 & 2270 & & & & & & & & & & & \\
\hline VEL3 & 2270 & & & & & & & & & & & \\
\hline ENDJ & & & & & & & & & & & & \\
\hline
\end{tabular}


Appendix 5.-Data used in emigration rate analysis in 1992.

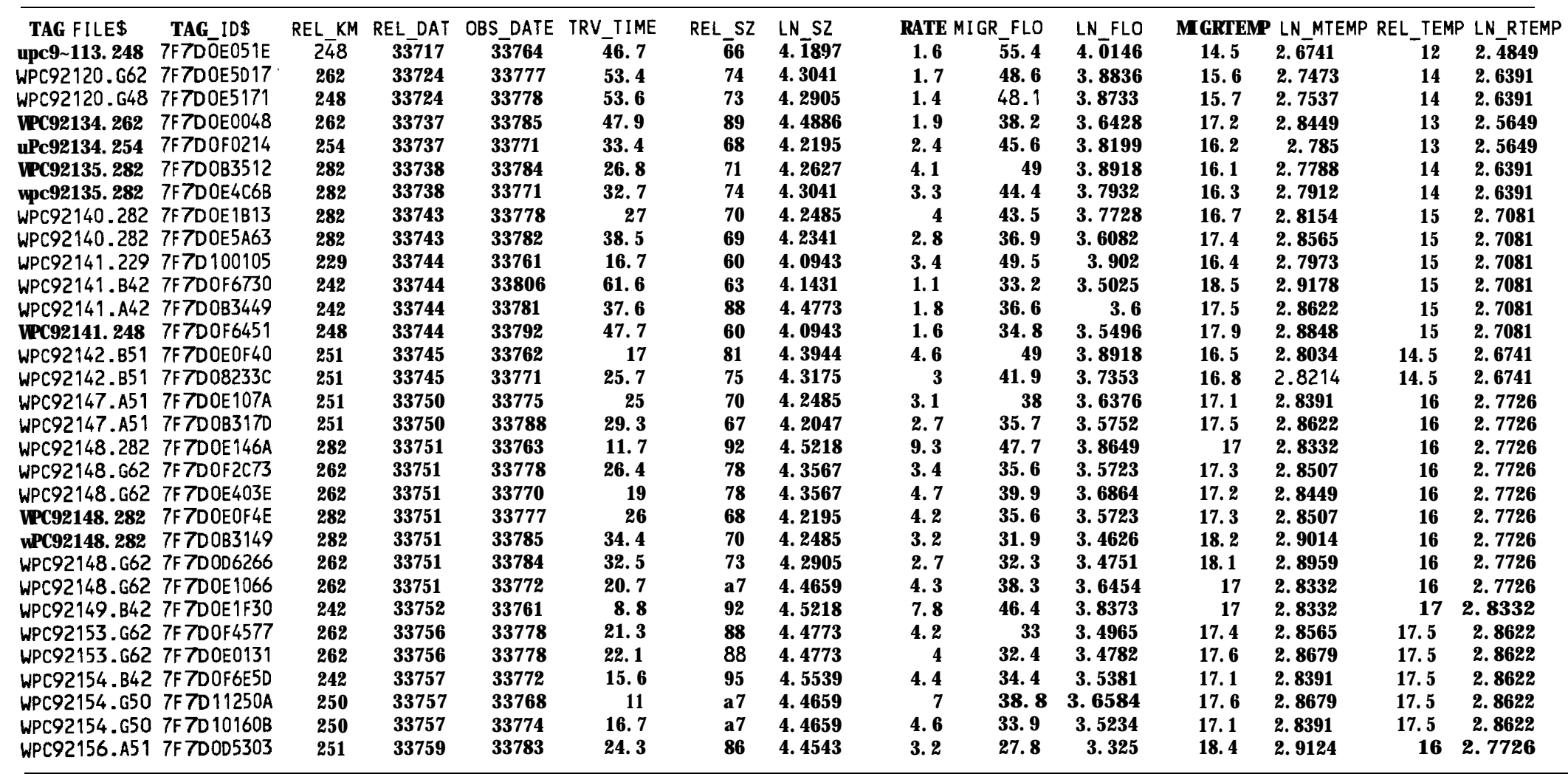


Appendix 6. -Total number of incidental fish caught by beach seine in McNary Reservoir and the Hanford Reach of the Columbia River, Washington, 1992.

\begin{tabular}{|c|c|c|c|}
\hline Common Name & Scientific Name & $\begin{array}{r}\text { Total } \\
\text { McNary }\end{array}$ & $\begin{array}{l}\text { Catch } \\
\text { Hanford }\end{array}$ \\
\hline American shad & Alosa sapidissima & 406 & 0 \\
\hline Black crappie & Pomoxis nigromaculatus & 1 & 1 \\
\hline Bluegill & Lepomis macrochirus & 18 & 1 \\
\hline Bridgelip sucker & Catostomus columbianus & 1 & 0 \\
\hline Coho salmon & Oncorhynchus kisutch & 1 & 0 \\
\hline Sculpins & Cottidae & 111 & 2 \\
\hline Crappie & Pomoxis spp. & 4 & 0 \\
\hline Carp & Cyprinus carpio & 35 & 4 \\
\hline Minnows & Cyprinid spp. & 94 & 42 \\
\hline Largemouth bass & Micropterus salmoides & 411 & 22 \\
\hline Largescale sucker & Catostomus macrocheilus & 23 & 15 \\
\hline Bass & Micropterus spp. & 3 & 0 \\
\hline Mountain whitefish & Prosopium williamsoni & 44 & 2 \\
\hline Peamouth & Mylocheilus caurinus & 117 & 378 \\
\hline Pumpkinseed & Lepomis gibbosus & 20 & 2 \\
\hline Redside shiner & Richardsonius balteatus & 1 & 899 \\
\hline Spring chinook & Oncorhynchus tshawytscha & 13 & 3 \\
\hline Smallmouth bass & Micropterus dolomieui & 73 & 25 \\
\hline Sunfish & Lepomis spp. & 6 & 0 \\
\hline Northern squawfish & Ptychocheilus oregonensis & 59 & 233 \\
\hline Threespine stickleback & Gasterosteus aculeatus & 30 & 2 \\
\hline Rainbow trout & Oncorhynchus mykiss & 1 & 0 \\
\hline Suckers & Catostomus spp. & 2507 & 86 \\
\hline Sand roller & Percopsis transmontana & 1 & 0 \\
\hline Yellow perch & Perca flavescens & 513 & 0 \\
\hline Unidentified & & 425 & 0 \\
\hline
\end{tabular}


Appendix 7.- Mean catch/seine haul (CPUE) of subyearling chinook salmon caught by beach seine during one week sampling intervals in McNary Reservoir and the Hanford Reach of the Columbia River, Washington and in the Snake River, Idaho, Oregon, and Washington, 1992.

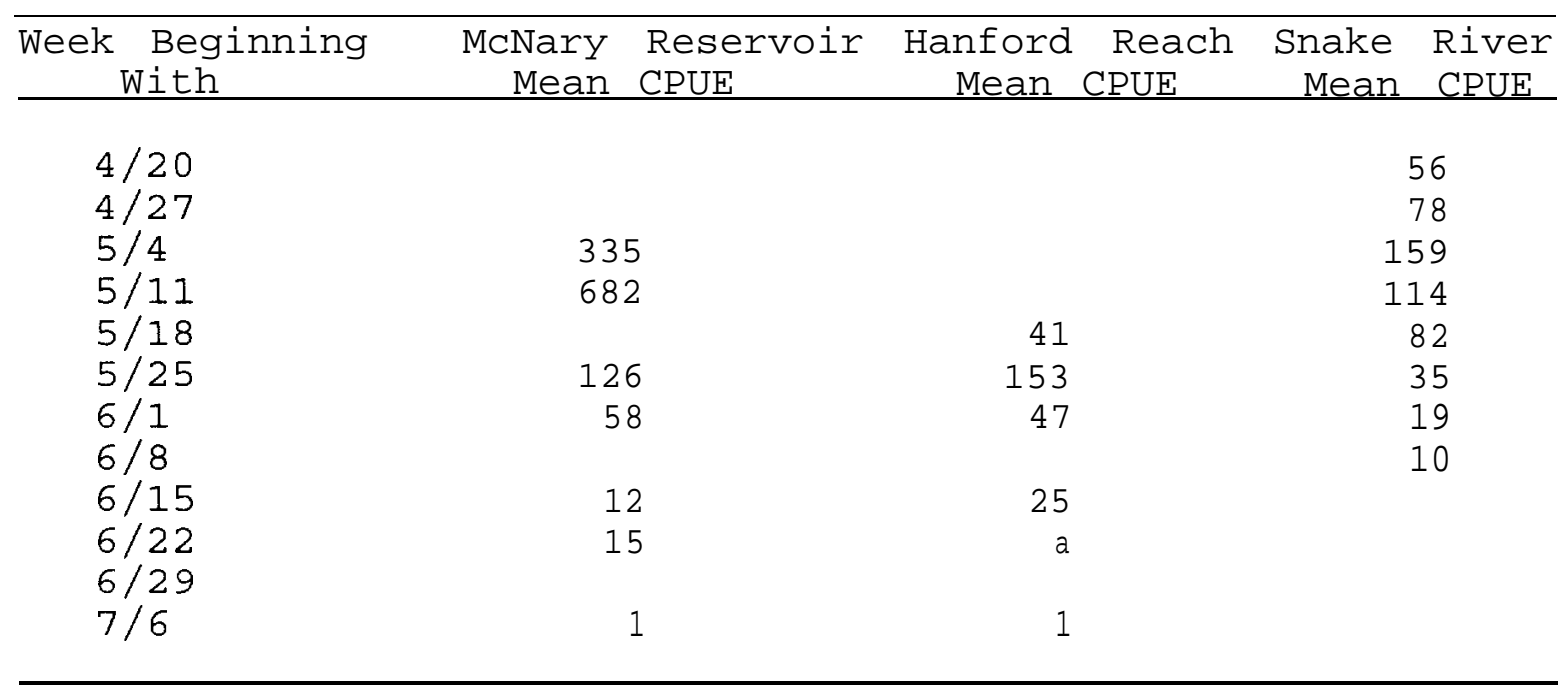

Appendix 8.- Mean fork length (FL) and standard deviation (SD) of subyearling chinook salmon caught by beach seine during one week sampling intervals in McNary Reservoir and the Hanford Reach of the Columbia River, Washington and in the Snake River, Idaho, Oregon, and Washington, 1992 .

\begin{tabular}{|c|c|c|c|c|c|c|}
\hline $\begin{array}{c}\text { Week Beginning } \\
\text { With }\end{array}$ & $\begin{array}{c}\text { McNary } \\
\text { FL }\end{array}$ & $\begin{array}{c}\text { Reservoir } \\
\text { SD }\end{array}$ & $\begin{array}{r}\text { Hanford } \\
\text { FL } \\
\end{array}$ & $\begin{array}{l}\text { Reach } \\
\text { SD }\end{array}$ & $\begin{array}{r}\text { Snake } \\
\text { FL }\end{array}$ & $\begin{array}{c}\text { River } \\
\text { SD }\end{array}$ \\
\hline $4 / 20$ & & & & & 46.1 & 8.4 \\
\hline $4 / 27$ & & & & & 49.6 & 9.7 \\
\hline $5 / 4$ & 49.3 & 6.2 & & & 51.4 & 8.5 \\
\hline $5 / 11$ & 51.4 & 8.4 & & & 58.9 & 10.0 \\
\hline $5 / 18$ & & & 46.9 & 5.4 & 62.6 & 10.1 \\
\hline $5 / 25$ & 56.0 & a. 3 & 54.1 & 6.2 & 69.8 & 12.3 \\
\hline $6 / 1$ & 63.4 & 9.5 & 58.8 & 8.8 & 79.0 & 10.7 \\
\hline $6 / 8$ & & & & & 86.9 & 9.6 \\
\hline $6 / 15$ & 77.3 & 10.8 & 73.1 & 9.4 & & \\
\hline $6 / 22$ & 84.2 & 9.2 & 75.2 & 8.9 & & \\
\hline $6 / 29$ & & & & & & \\
\hline $7 / 6$ & 89.6 & 9.3 & 88.5 & 4.8 & & \\
\hline
\end{tabular}


Appendi x 9. Summary of the number of subyearling chi nook sal non narked with coded wire tags and brands or consi dered not sui table for marking at McNary Dam during 1992.

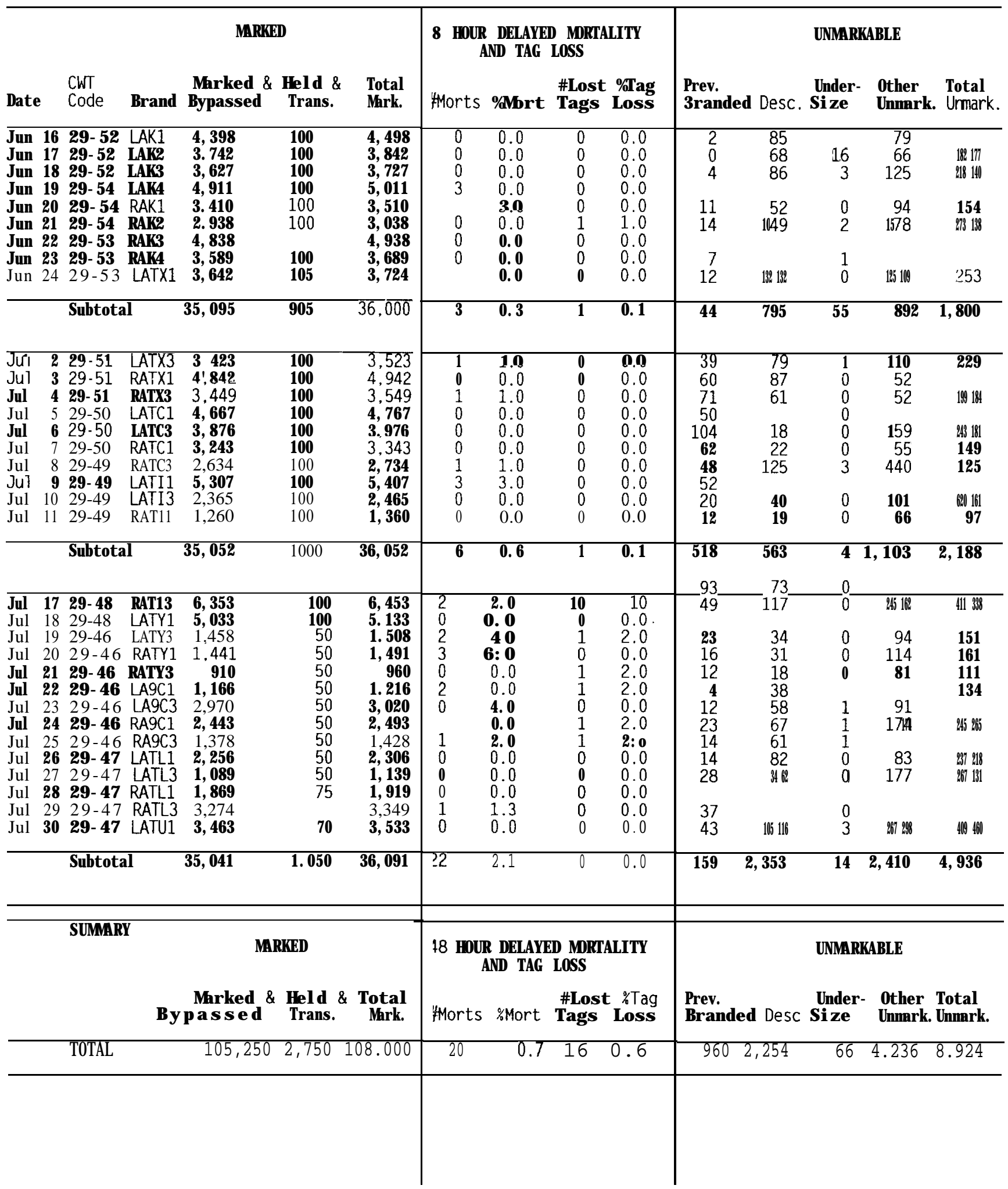

